
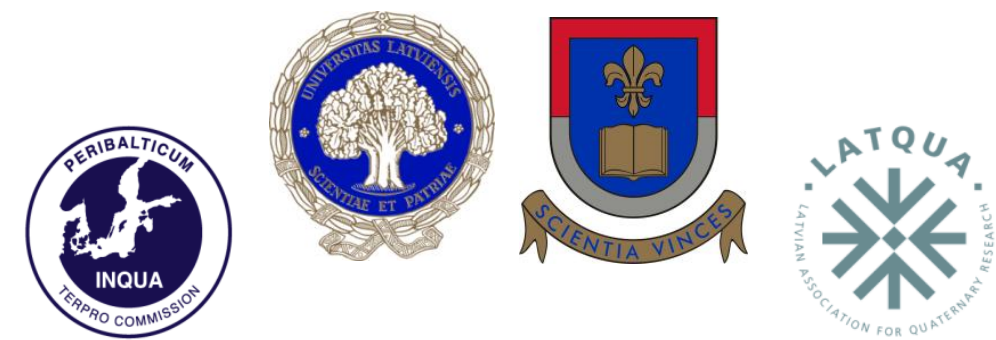

INQUA TERPRO COMMISSION PERIBALTIC WORKING GROUP

UNIVERSITY OF LATVIA

UNIVERSITY OF DAUGAVPILS

LATVIAN ASSOCIATION FOR QUATERNARY RESEARCH

\title{
LATE QUATERNARY \\ TERRESTRIAL PROCESSES, SEDIMENTS AND HISTORY: FROM GLACIAL TO POSTGLACIAL ENVIRONMENTS
}

EASTERN AND CENTRAL LATVIA

AUGUST 17-22, 2014 


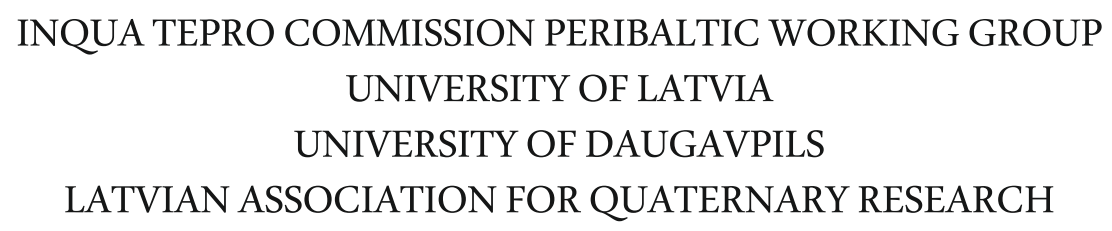

\title{
LATE QUATERNARY \\ TERRESTRIAL PROCESSES, SEDIMENTS AND HISTORY: FROM GLACIAL TO POSTGLACIAL ENVIRONMENTS
}

\author{
EASTERN AND CENTRAL LATVIA
}

AUGUST 16-22, 2014 
Organized by:

University of Latvia

Daugavpils University

Latvian Association for Quaternary Research

INQUA Peribaltic Working Group (INQUA TERPRO Commission)

Organizing committee:

Māris Nartišs (Chair, University of Latvia)

Māris Krievāns (Secretary, University of Latvia)

Aivars Markots (University of Latvia)

Juris Soms (Daugavpils University)

Evija Tērauda (University of Latvia)

Vitālijs Zelčs (University of Latvia)

Contributors:

Ivars Celiņš, Edgars Greiškalns, Ieva Grudzinska, Edyta Kalińska-Nartiša, Laimdota Kalniņa, Jānis Karušs, Māris Krievāns, Kristaps Lamsters, Aivars Markots, Māris Nartišs, Agnis Rečs, Normunds Stivriņš, Juris Soms, Ivars Strautnieks, Santa Strode, Sandra Zeimule, Vitālijs Zelčs

Editors: Vitālijs Zelčs and Māris Nartišs

The English texts of the field guide were revised by Valdis Bērziņš

Recommended reference for this publication:

Zelčs, V. and Nartišs, M. (eds.) 2014. Late Quaternary terrestrial processes, sediments and history: from glacial to postglacial environments. Excursion guide and abstracts of the INQUA Peribaltic Working Group Meeting and field excursion in Eastern and Central Latvia, August 17-22, 2014. University of Latvia, Rīga, 2014, 150 pages.

Sponsored by:

University of Latvia

Layout: Vitālijs Zelčs, Māris Nartišs and Māris Krievāns

ISBN 078-9934-517-60-0

(C) University of Latvia, 2014

This volume is available from:

Faculty of Geography and Earth Sciences

University of Latvia

Rainis Blvd. 19

Rìga, LV1586

Latvia 


\section{CONTENTS}

Preface.

Schedule and excursion itinerary.....

Outlines of the Quaternary geology of Latvia / Vitālijs Zelčs and Māris Nartišs/......

\section{GUIDE FOR FIELD TRIP}

STOP 1: Lower Gauja spillway valley at Sigulda /Māris Krievāns, Vitālijs Zelčs and Māris Nartišs/...

STOP 2: Late-glacial and postglacial environmental changes, Lake Āraiši, Vidzeme Upland /Normunds Stivriņš/.

STOP 3: Late-glacial and early postglacial environmental processes and the history of the River Triečupite valley and surroundings, in the foreland of the Vidzeme Upland /Māris Krievāns and Laimdota Kalniņa/...

STOP 4: Internal structure and genesis of the sediments underlying Terrace III of the River Gauja at Dukul̦i farmhouse and Valmiera town /Māris Krievāns and Agnis Rečs/......

STOP 5: Veselava end moraine, north-western Vidzeme Upland /Vitālijs Zelčs, Māris Krievāns and Ivars Strautnieks/...

STOP 6: Morphology, internal structure and texture of inland dunes at Smilškalni site, Middle Gauja Lowland /Ivars Celiņš, Jānis Karušs, Edyta Kalińska-Nartiša, Māris Nartišs/.

STOP 7: Madona-Trepe ice-marginal ridge at Smeceres sils, East-Latvian Lowland /Vitālijs Zelčs, Māris Krievāns and Māris Nartišs/.

STOP 8: Morphology and arrangement of glaciokarst kettles at Vietalva village /Jānis Karušs, Māris Krievāns and Agnis Rečs/........................................... STOP 9: Upper Daugava spillway valley and associated gully network at

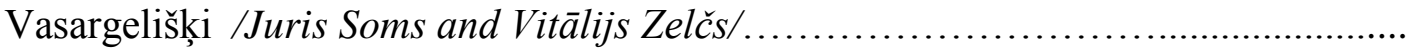
STOP 10: Kame terrace in the Upper Daugava depression at Rakuti, near Krāslava IVitālijs Zelčs, Juris Soms and Edgars Greiškalns/.

STOP 11: Recessional moraine ridge at Veresovka, Rāzna glacial depression IVitālijs Zelčs, Juris Soms, Aivars Markots and Ivars Strautnieks/.

STOP 12: Late glacial and Holocene development of Lake Rāzna as recorded by biostratigraphy /Sandra Zeimule, Laimdota Kalnina and Ieva Grudzinska/....

STOP 13: Inland dune field near Daugavpils, East-Latvia Lowland /Edyta KalińskaNartiša, Māris Nartišs, Juris Soms and Santa Strodel.

STOP 14: Morphology and internal structure of Lāči drumlin at Tērvete village, Zemgale Drumlin Field /Kristaps Lamsters and Vitālijs Zelčs/................................. STOP 15: Morphology and internal structure of a ribbed moraine and drumlin remnant in the environs of Baldone, Central Latvian Lowland /Kristaps Lamsters and Vitālijs Zelčss/.....

\section{ABSTRACTS OF PAPERS AND POSTERS}

Paper and poster session programme.

Map of ice-marginal formations of European Russia /Valery Astakhov, Valentina Shkatova, Andrei Zastrozhnov and Margarita Chuyko/.............................. Palaeoenvironmental changes and stratigraphy of Quaternary deposits of Lithuania /Valentinas Baltrūnas, Bronislavas Karmaza, Valentas Katinas, Vaida Šeirienè and Rimante Zinkutèl. 
Mapping shallow groundwater surface in terrigenous sediments using ground penetrating radar /Dāvids Bērziņš and Jānis Karušs/............................... Groundwater flow peculiarities induced by post-glacial and modern karst, Skaistkalne vicinity, Central Latvian plains /Jānis Bikše, Konrāds Popovs, Aija Dèlina and Alise Babre/......................................................... Palaeoecological investigations and ${ }^{230} \mathrm{Th} / \mathrm{U}$ dating of Eemian interglacial peat sequence of Banzin, Mecklenburg-Western Pomerania, NE-Germany /Andreas Börner, Anna Hrynowiecka, Vladislav Kuznetsov and Renata Stachowicz-

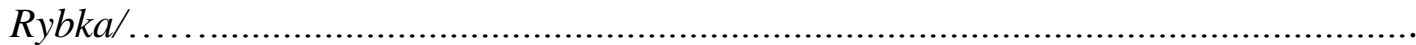
The EU Encore Fresh Water Project: from fundamental research towards practice /Enno P. H. Bregman/...

The Late Saalian Hondsrug megaflute, Drenthe, The Netherlands: the base of an unique new European Geopark /Enno P. H. Bregman, Ilze Lūse, Mark Bakker, Harm J. Pierik, Florian W. H. Smit and Kim M. Cohen/............................ Effect of buried valleys on groundwater flow: a case study in the vicinity of Ventspils, NW Latvia /Aija Dēliņa, Kristīne Düdiņa and Konrāds Popovs/...

New data on the palaeoenvironment of South-Eastern Baltic region: results of the scientific project RFBR 1205-33013 /Olga Druzhinina/.....

Post-glacial environmental changes and the earliest human inhabitance of the Lake Dukštelis area, Eastern Lithuania /Laura Gedminiene, Gabriele Rimkute and Migle Stančikaitél.

Development of the Plateliai area in Late Weichselian and Holocene, NW Lithuania /Alma Grigienè and Asta Jusienèl.

Current issues of geological mapping in Schleswig-Holstein, Germany /Alf Grube/... Late Quaternary ice sheet dynamics in northeastern Germany - new insights in the formation of the Frankfurt ice marginal position based on the analysis of a high resolution LiDAR digital elevation model /Jacob Hardt and Margot Böse/............. ABCGheritage project - geological cooperation in northern Fennoscandia /Peter Johansson, Yury Voytekhovsky, Laura S. Lauri and Jouni Pihlaja/.................... Application of the pulsed OSL in feldspar contaminated aeolian sediments: a case study of Eastern Latvia and Southern Estonia /Edyta Kalińska-Nartiša, Māris Nartišs, Christine Thiel, Jan-Pieter Buylaert and Andrew Sean Murray/..

Deglacial ice dynamics in Estonia as derived from glacial bedforms /Katrin Kalla and Tiit Hang/.....

Morphogenetic classification of kame terraces in the Late Nemunas glaciation area of Lithuania /Danguole Karmaziené/.....

The isolation stratigraphy of small lakes in northern Lake Ladoga basin in reconstructions of the Baltic Ice Lake final stage and early Holocene glacioisostatic uplift /Denis Kuznetsov, Anna Ludikova and Tatyana Sapelko/.....

Glacial landforms in the forefield of Múlajökull surge-type glacier, Central Iceland /Kristaps Lamsters and Jānis Karušs/.....

Carbonate cements in glacial sediments: a palaeohydrologic indicator of glacial environment /Pille Lomp and Maris Rattas/.

The diatoms of the Baltic Ice Lake: new data from the Lake Ladoga region, the easternmost part of the Baltic Ice Lake /Anna Ludikova/............................. Upper Dnieper River since LGM: ice damming, glacio-isostatic effects and climatic forcing /Andrei Panin/.... 
Heavy minerals as indicators of the source areas of the sediments in the TorunEberswalde ice-marginal valley, NW Poland /Małgorzata Pisarska-Jamroży, A.J. (Tom) van Loon, Barbara Woronko and Beata Sternal/...

Records of natural and human-induced environmental changes in Latvian lake sediments /Agnese Pujāte, Karina Stankeviča, Anda Dručka, Anda Staškova, Aija Ceriņa, Laimdota Kalniņa and Elīza Kušķe/.....

The links between Quaternary palaeosurfaces and present surface of South Lithuania /Violeta Pukelytél....

Chemical characterization of Quaternary groundwaters in Latvia: a case study of trace element content /Inga Retiķe, Jānis Bikšse, Andis Kalvāns, Alise Babre, Gunta Kalvāne and Konrāds Popovs/.....

Lithological variability in tills of the Samogitian Upland and surrounding area, Lithuania /Eugenija Rudnickaite and Rimante Guobytè/....

Cyclic sedimentation pattern in the Lake Veetka, SE Estonia /Leili Saarse/........... Low-impact exploration methods promoting the Green Mining concept in Finland /Pertti Sarala/....

Extra short glacial transport - mechanisms and application /Pertti Sarala and Vesa Peuraniemil............................................................... Stratigraphy of Quaternary deposits, Sheet P-39 (Syktyvkar) /Lyudmila P. Semenova, Andey V. Stepunin, Anton V. Maksimov and Tatyana I. MarchenkoVagapoval.

Palaeovegetation changes recorded by macroscopic fossil investigation data from Lake Ummis and Lake Mazais Ungurs sediments, Latvia /Anda Staškova, Aija Ceringa, Agnese Pujāte and Laimdota Kalniņa/.

Freshwater travertines from NW Russia - terrestrial archives of paleoenvironmental information /Eriks Tabuns, Kathrine Kuksa, Mikhail Nikitin, Snezhana Levchenko, Jonathan Baker and Vasiliy Grigoriev/....................................... Investigation of stable isotopes and diatom assemblages - a key for paleoenvironmental reconstruction, Curonian Lagoon, Lithuania /Giedré Vaikutiené, Raminta Skipitytè, Jonas Mažeika, Tõnu Martma, Andrius Garbaras and Rūta Barisevičiūtèl.

Pleistocene glacio-isostatic seismites in NW Poland /A.J. (Tom) van Loon and Małgorzata Pisarska-Jamroży/...........................................

MIS 2 alluvial terrace and the problem of the LGM proglacial lake in the River Vychegda valley, North-East Europe /Nataliya Zaretskaya, Andrei Panin and

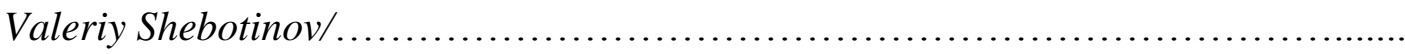
A giant loadcast resulting from ice re-advance over an esker near Ryssjön, South Sweden /A. J. (Tom) van Loon and Beata Gruszka/...................................

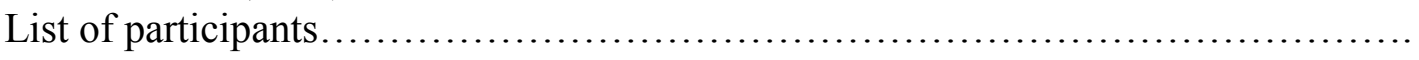
For notes. 


\section{Preface}

The INQUA Peribaltic Working Group started in early 1990-s and brings together researchers active in different fields of Quaternary science. The Working Group activities are subordinated to the INQUA Commission on Terrestrial Processes, Deposits and History (TERPRO). Regular meetings and field symposiums devoted to various aspects of Quaternary have been the main events organised by the Group for more than two decades.

The annual (according to the best available data $-22^{\text {nd }}$ ) Peribaltic field symposium takes place from 17 to 22 August, 2014 in Eastern and Central Latvia. This scientific event is hosted by the University of Latvia and the Daugavpils University. The main topic of the symposium is "Late Quaternary Terrestrial Processes, Sediments and History: from Glacial to Postglacial Environments". More than 50 participants from 8 countries come together to report, discuss and share the latest findings and insights into Quaternary.

The symposium includes one day of oral and poster presentations, and a four-day field excursion to Eastern and Central Latvia. At the meeting 37 lectures are given, 13 of which are oral presentations and 24 poster presentations. In the course of the field excursion we visit 15 stop sites. Most of them are recently studied but some localities are re-investigated during last years. We hope that these stops will provide an excellent background for discussions and planning of scientific cooperation.

This volume contains the revised description of the field excursion sites and abstracts of the papers. It deals with various aspects of glacial geology, biostratigraphy, event stratigraphy, sequence stratigraphy, isotopic geochronology, applied and regional aspects of Quaternary science. Results of some investigations there are preliminary because they are not finished yet.

We are pleased to welcome all the participants of the symposium on behalf of the Organizing Committee. We wish everybody useful discussions, creative solutions and interesting excursion days full of Quaternary impressions. We trust that this meeting will contribute to consolidating of forces and promote further development of Quaternary science.

Vitālijs Zelčs, Māris Nartišs and Juris Soms 


\section{Schedule and field excursion itinerary}

$17^{\text {th }}$ August 10:00 Registration at the Faculty of Geography and Earth Sciences, University of (Sunday) Latvia, Alberta Str. 10, Rīga

18:00 Departure for the Ratnieki conference and recreational centre of the University of Latvia, Līgatne municipality, Cēsis district, Latvia

19:00 Accommodation and dinner in Ratnieki

$18^{\text {th }}$ August

(Monday)

$19^{\text {th }}$ August

(Tuesday)

$20^{\text {th }}$ August

(Wednesday)

$21^{\text {th }}$ August

(Thursday)

22 August

(Friday)
7:00 Breakfast

8:00 Departure for the field trip from Ratnieki

STOP 1: Lower Gauja spillway valley at Sigulda

STOP 2: Late-glacial and postglacial environmental changes, Lake Āraiši, Vidzeme Upland

Lunch

STOP 3: Late-glacial and early postglacial environmental processes and the history of the River Triečupite valley and surroundings, in the foreland of the Vidzeme Upland

STOP 4: Internal structure and genesis of the sediments underlying Terrace III of the River Gauja at Dukul,i Farmhouse and Valmiera Town

19:00 Arrival at Ratnieki: accommodation and dinner

20:00 Sauna

8:00 Breakfast

9:00 Paper sessions in the conference hall of Ratnieki: oral and poster presentations

17:00 INQUA Peribaltic Working Group business meeting

19:00 Symposium dinner

7:00 Breakfast

8:00 Departure for the field trip from Ratnieki

STOP 5: Veselava end moraine, north-western Vidzeme

STOP 6: Morphology, internal structure and texture of inland dunes at Smilškalni site,

Middle Gauja Lowland

Lunch

STOP 7: Madona-Trepe ice-marginal ridge at Smeceres sils, East-Latvian Lowland

STOP 8: Morphology and arrangement of glaciokarst kettles at Vietalva village

19:00 Arrival at Daugavpils: accommodation and dinner in Good Stay Dinaburg Hotel

7:00 Breakfast

8:00 Departure for the field trip from Good Stay Dinaburg Hotel

STOP 9: Upper Daugava spillway valley and associated gully network at Vasargelišķi

STOP 10: Kame terrace in the Upper Daugava depression at Rakuti, near Krāslava

STOP 11: Recessional moraine ridge at Veresovka, Rāzna glacial depression

Lunch

STOP 12: Late-glacial and Holocene development of Lake Rāzna as recorded by biostratigraphy

STOP 13: Inland dune field near Daugavpils, East-Latvian Lowland

19:00 Arrival at Good Stay Dinaburg Hotel: dinner and sauna

7:00 Breakfast

8:00 Departure for the field trip from the Good Stay Dinaburg Hotel

STOP 14: Morphology and internal structure of the Lāči drumlin at Tērvete village, Zemgale Drumlin Field

STOP 15: Morphology and internal structure of a ribbed moraine and drumlin remnant in the environs of Baldone, Central Latvian Lowland

About 17:00 Arrival at the Riga Airport

18:00 Arrival at the Faculty Geography and Earth Science, Alberta Str. 10 


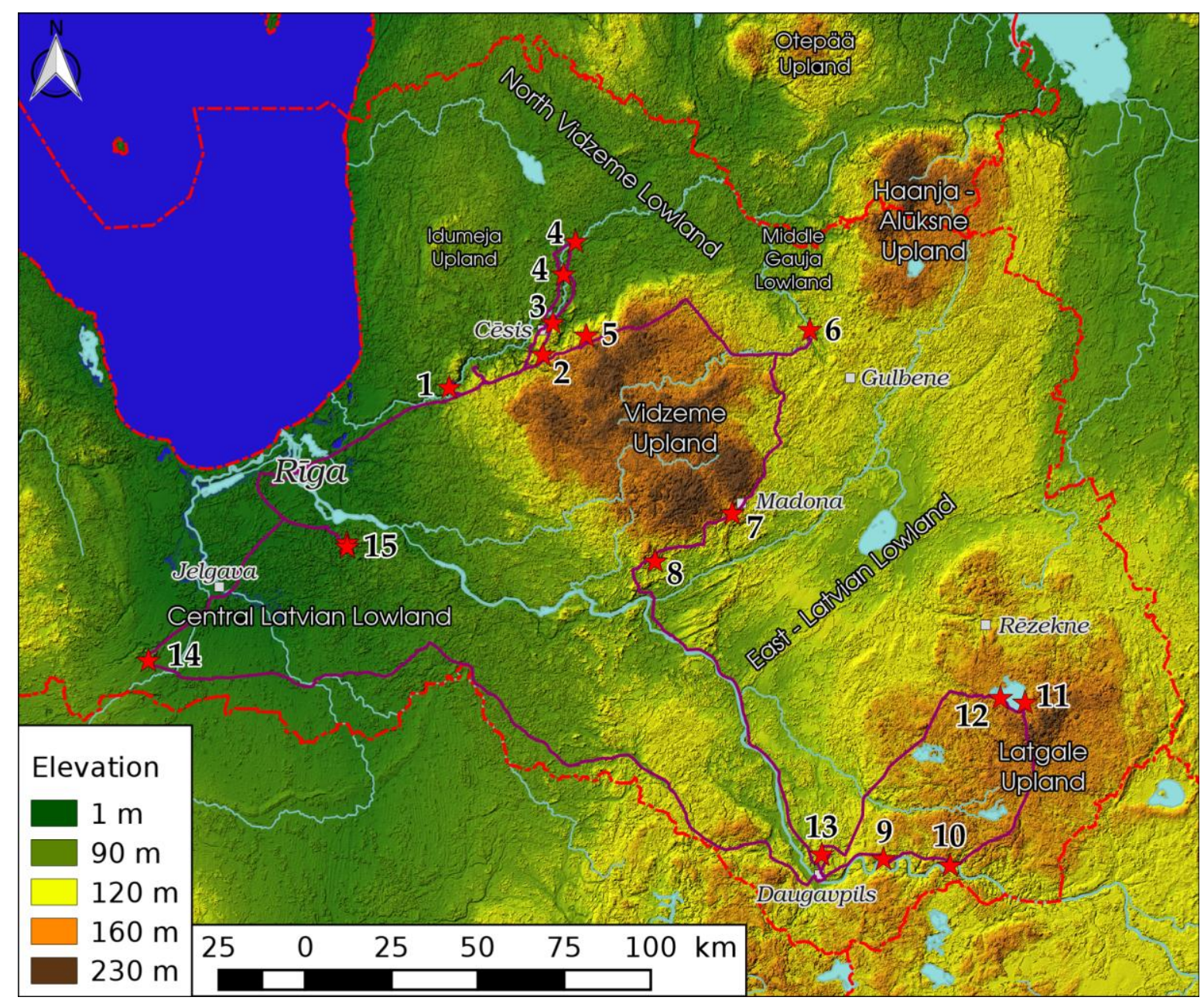

Fig. I. Physical geographic map of Eastern and Central Latvia with respect to location of field sites visited during the field excursion (compiled by Nartišs). Numbers denote the stop sites. STOP 1: Lower Gauja spillway valley at Sigulda STOP 2: Lake Āraiši, Vidzeme Upland STOP 3: River Triečupīte and freshwater tufa at Priekuļi STOP 4: River Gauja scarps at the Dukul̦i Farmhouse and Valmiera Town ('Stāvie krasti') STOP 5: Veselava end moraine, north-western Vidzeme Upland STOP 6: Inland dunes at the Smilškalni site, Middle Gauja Lowland STOP 7: Madona-Trepe ice-marginal ridge at the Smeceres sils, East-Latvian Lowland STOP 8: Morphology and arrangement of glaciokarst kettles at the Vietalva village STOP 9: Upper Daugava spillway valley and associated gully network at Vasargelišķi STOP 10: Kame terrace in the Upper Daugava depression at Rakuti, near Krāslava STOP 11: Recessional moraine ridge at Veresovka, Rāzna glacial depression STOP 12: Late-glacial and Holocene development of Lake Rāzna at Zosnasgals STOP 13: Inland dunes at Gijantari, Daugavpils environs STOP 14: Drumlin at the Lāči Farmhouse, Tērvete, Zemgale drumlin field STOP 15: Ribbed moraine and drumlin remnant in the environs of Baldone 


\section{Outlines of the Quaternary geology of Latvia}

Vitālijs Zelčs and Māris Nartišs

University of Latvia

Latvia is one of the three south-eastern Baltic countries. It is situated geographically between Estonia and Lithuania. Latvia is bordered by Russia in the east and Belarus along its south-east corner. The territory of Latvia covers an area $64,589 \mathrm{~km}^{2}$. The Baltic Sea lies along its west side, and the Gulf of Riga penetrates in the central part from the north.

The territory of Latvia is located on the western side of the East European platform. The platform is bordered on the north by the southern slope of the Baltic Shield. In the subsurface, the Precambrian basement of crystalline rocks and succeeding Upper Proterozoic and Palaeozoic sedimentary rocks underlie the territory of Latvia The total thickness of sedimentary bedrock is increases from less than $0.5 \mathrm{~km}$ in the north-east borderland up to about $2 \mathrm{~km}$ in the south-west (Dreimanis and Kārklinš 1997). The surface of the crystalline basement is covered, in ascending stratigraphic order, by Ediacaran, Cambrian, Ordovician, Silurian, Devonian, Carboniferous, Permian, Triassic and Jurassic deposits.

The Devonian sedimentary rocks lie in the shallow depth and compose the topmost part of the pre-Quaternary sequence in all area of Latvia with exception of its south-western part, where they are replaced by Carboniferous, Permian, Triassic and Jurassic deposits.

Quaternary deposits of various thickness and age cover almost all Latvian territory, with the exception of restricted bedrock outcrop areas - mainly erosional plains of the Baltic Ice Lake in the north of Latvia, along and in river valleys. The average thickness of the Quaternary deposits is 5-20 $\mathrm{m}$ in the lowlands and 40-60 $\mathrm{m}$ in the uplands (Fig. 1). Locally, along the southern, south-western and south-eastern sides of the bedrock elevations, e.g. in the Vidzeme Upland, and in east-central Latvia, between the towns of Cēsis and Madona the thickness of the Quaternary deposits may reach up to $200 \mathrm{~m}$ (Fig. 1). The greatest thickness of the Quaternary deposits $(310 \mathrm{~m})$ occurs in the Akniste buried valley in southeastern Latvia. Most of the Quaternary deposits are glacial and of the Late Pleistocene age (Zelčs et al. 2011).

Latvia is located within the area of the Fennoscandian Ice Sheet, and so the sediments of previous interglacials are rarely found in the Quaternary cover (Dreimanis and Zelčs 1995). Lithostratigraphical, biostratigraphical and geochronological information available indicate the occurrence deposits of three Pleistocene interglacials - Cromerian (termed locally as Židiņi), Holsteinian (Pulvernieki) and Eemian (Felicianova), and tills of Elsterian (Lētiža), Saalian (Kurzeme) and Weichselian (Baltija) glacials. In eastern Latvia (Vidzeme, Alūksne, particularly Latgale and Augšzeme) uplands and buried valleys have not only a greater than average Pleistocene sediment thickness (Fig. 1) but also display stratigraphically complex sections. However, on the basis of present knowledge, there is no conclusive evidence to support the presence of tills of the Early Pleistocene (Latgale) glaciation, as it was suggested by Danilāns (1973). Therefore, up to $0.51 \mathrm{~m}$ thick diamicton-like material that was encountered in test drilling section No. II (Danilāns et al. 1964), located in south-eastern Latvia between towns of Krāslava and Daugavpils at the base of plaeolake sediment sequence, and recently studied by Kalnina et al. (2013), can most likely be correlated with the Cromerian complex of early Middle Pleistocene.

The internal structure of the Pleistocene sequence has in many places been complicated by glaciotectonic deformation (Āboltiņš and Dreimanis 1995; Dreimanis and Zelčs 1995; Molodkov et al. 1998; Saks et al. 2012). Older sediments have been emplaced above younger 
ones as megablocks, or as overthrusts and complex folds (Āboltiňš 1989; Zelčs and Dreimanis 1997). As a result of glaciotectonism and glacial erosion the Pleistocene sequence has also undergone large-scale sediment redistribution and remarkable complication of its structure.

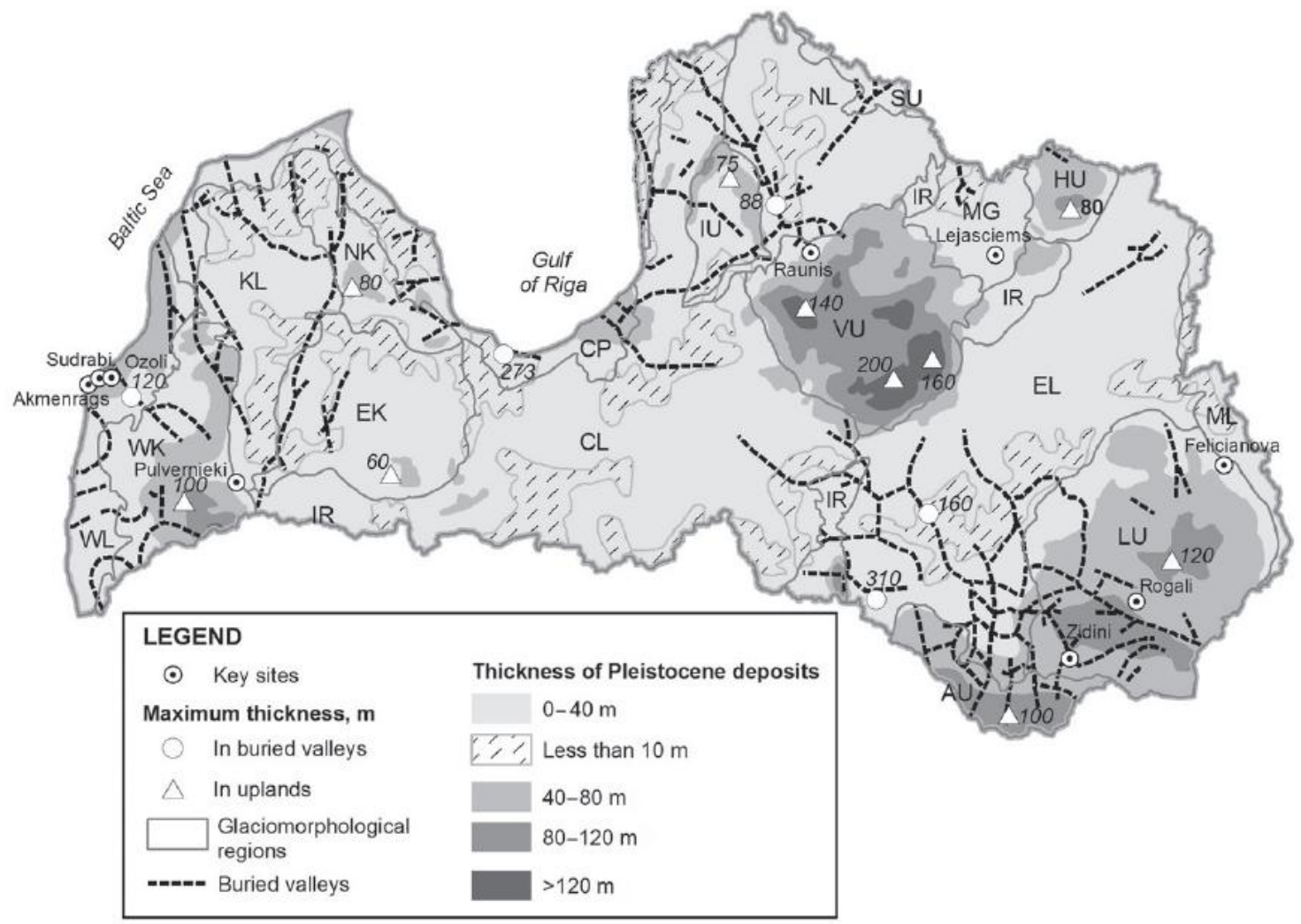

Fig. 1. Thickness of the Quaternary deposits in Latvia (modified after Zelčs et al. 2011).

Glacial lowlands: WL - Western Latvian, KL - Kursa, CL - Central Latvian, NL - Northern Latvian, MG Middle Gauja, EL - East-Latvian, ML - Mudava (Velikoretsky).

Glacial uplands: WK - Western Kursa, NK - Northern Kursa, EK - Eastern Kursa, IU - Idumeja, VU Vidzeme, HU - Alūksne-Haanja, LU - Latgale, AU - Augšzeme, IR - Interlobate ridges.

Glaciotectonic deformation structures are extremely common in the Weichselian deposits and thus complicate their stratigraphical interpretation. Only deposits of the Late Weichselian glaciation are present throughout almost all of Latvia. These deposits have a dominant role in the Pleistocene sequence of the glacial uplands and lowlands. The Late Weichselian non-deformed and glaciotectonised till and stratified deposits are also the main landforming material.

The extent and timing of Pleistocene glaciations, particularly Upper Pleistocene events, in Latvia have traditionally been interpreted on the basis of palynological studies, crosscorrelation of lithological data, radiocarbon dates of plant remains from organic and organicbearing sediments, „sub-fossil” reindeer finds and mammoth tooth enamel samples (e.g. Ukkonen et al. 2006; Arppe and Karhu 2010), and results obtained by TL, OSL (e.g. Zelčs et al. 2011; Saks et al. 2012) and ESR (Molodkov et al. 1998) dating techniques. The chronology of the last deglaciation of the southern sector of the Fennoscandian Ice Sheet, including the territory of Latvia, has also been established following the results of the cosmogenic ${ }^{10} \mathrm{Be}$ determination (Rinterknecht et al. 2006).

Latvia is located on the slightly undulating, in places flat northwestern margin of the East European Plain characterised by moderate variations in elevation. The average height is about $87 \mathrm{~m}$. The highest point is Hill Gaizinkalns (312 m a.s.1.) in the Vidzeme Upland. 
Almost $75 \%$ of Latvia lies below $120 \mathrm{~m}$ a.s.1., and elevations higher than $200 \mathrm{~m}$ are restricted to less than $3 \%$ of the territory. The average local relief rarely exceeds $10-25 \mathrm{~m}$ with a maximum up to $90 \mathrm{~m}$ in eastern Latvian glacial uplands, and in some places along proglacial spillways (Zelčs et al. 2011). The landscape of Latvia is dominated by Pleistocene glacial landforms, except for a belt of coastal plains along the Baltic Sea and Gulf of Rìga shore.

The present-day topography has largely been formed as a result of Pleistocene glaciations, particularly of the last Weichselian event. Most of the glacigenic landforms were created during oscillatory retreat of the Late Weichselian Fennoscandian Ice Sheet, when it was divided into several more or less independently flowing ice lobes and glacier tongues (Fig. 2). The Last glacial maximum limit is located outside of Latvia.

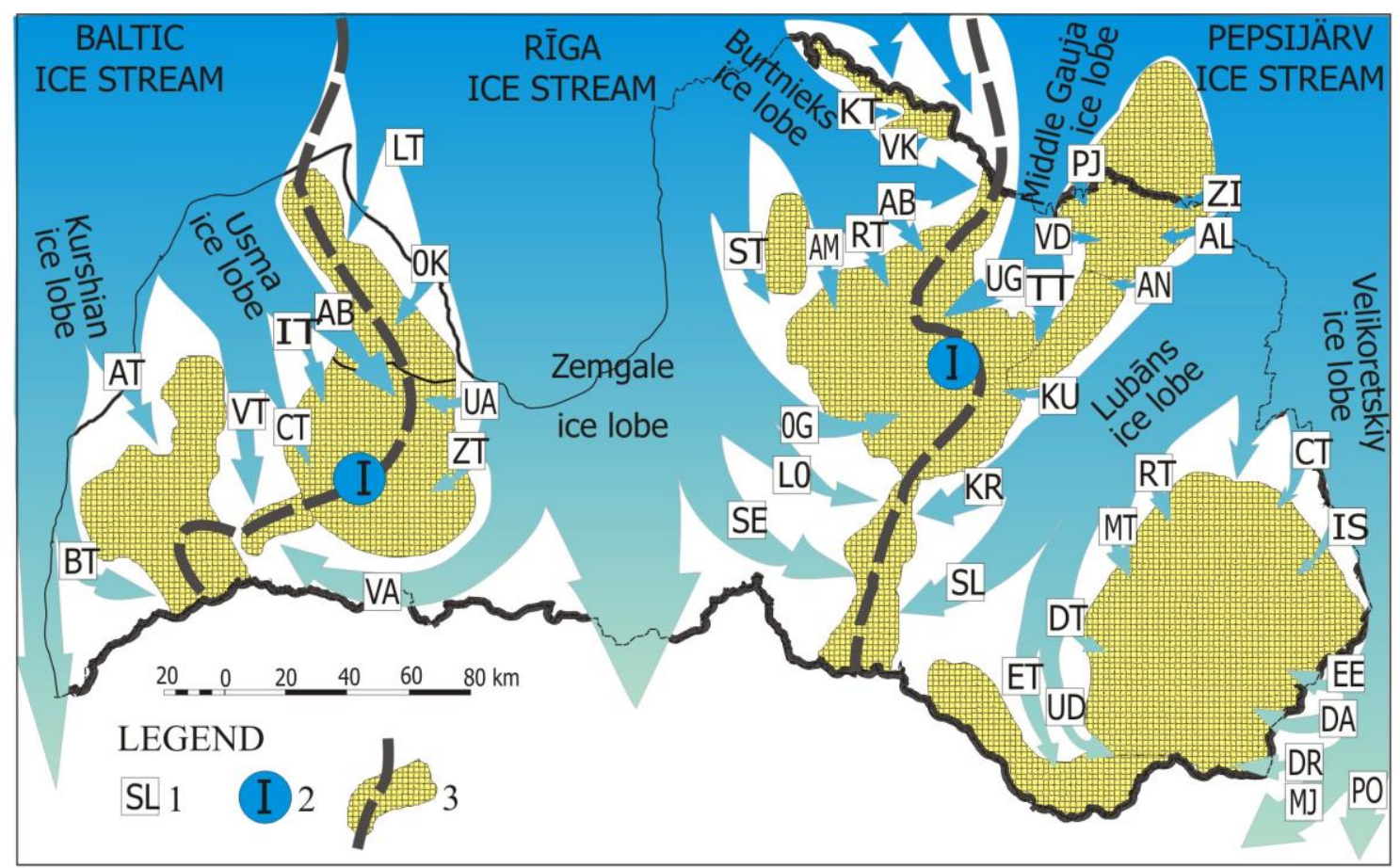

Fig. 2. Lobate structure of the peripheral cover of the Fennoscandian Ice Sheet in Latvia during transgression and decaying of the Late Weichselian glaciation (modified after Zelčs and Markots 2004).

$1=$ Ice tongues: $\mathrm{BT}=\mathrm{Bārta} ; \mathrm{AT}=$ Apriksi; $\mathrm{VT}=$ Venta; $\mathrm{CT}=$ Ciecere; $\mathrm{AB}=$ Abava; $\mathrm{IT}=\mathrm{Imula} ; \mathrm{LT}=$ Laidze; OK = Oksle; UA = Upper Abava; ZT = Zebrus; VA = Vadakste; SE = Sēlian; LO = Lobe; OG = Ogre; $\mathrm{ST}=$ Straupe; AM = Amata; RT = Rauna; $\mathrm{AB}=$ Abuls; VK = Valka; KT = Kārķi; UG = Upper Gauja; TT = Tirza; VD = Vaidava, PJ = Perlijõgi; ZI = Ziemeri; AL = Alūksne; AN = Anna; KU = Kuja; KR = Krustpils; SL = Slate; ET = Eglaine; UD = Upper Daugava; DT = Dubna; MT = Malta; RT = Rēzekne; CT = Cirma; IS = Istra; EE = Ežezers; DA = Dagda; DR = Druja; MJ = Mjori; PO = Polatsk. 2 = Main interlobate zones: I = Baltic - Rīga; II = Rīga - Peipsijärv. 3 = Interlobate uplands and heights (ridges).

More than $60 \%$ are glacial lowlands which occupy large-scale depressions within the sub-Quaternary surface. Most glacial uplands are insular-shaped and bedrock-cored. Uplands and lowlands can be considered as the largest scale or macrorelief glacial landforms. Processes of glacial accumulation, with particular importance of selective glacial erosion, glaciotectonics and proglacial meltwater activity, have resulted in the formation of lowlands, while proglacial and subglacial accumulation and glaciotectonics have dominated in the glacial uplands.

Three varieties of glacial uplands and three main types of lowlands can be distinguished in Latvia, based on hypsometric position, thickness and structure of the Pleistocene cover, and 
glacial topography (Zelčs and Markots 2004). Latvia was located in the inner belt of the depositional zone of the Fennoscandian Ice Sheet where the main features of glacial topography were created by subglacial processes. During the last glaciation it was affected by the Baltic, Rīga and Peipsijärv (Peipsi Lake) ice streams. The ice streams were terminated in lobes and tongues which merged in areas of the interlobate zones during transgression of the Late Weichselian glaciation. The insular uplands and interlobate ridges represent zones of convergence of ice lobes moving in different directions and through separate neighbouring lowlands (Zelčs et al. 2011).

The formation and location of ice lobes and glacier tongues, and their dynamics were initially highly controlled by the geological setting of the pre-Quaternary bedrock but during the last glaciation mainly by the pre-Weichselian surface. The influence of the subglacial topography increased particularly during deglaciation, as the ice thickness decreased. A very complex lobate structure with many small glacier tongues and sub-tongues were existed in the early phases of the deglaciation, so-called 'insular deglaciation stage' by Āboltiņš et al. 1972. Later, during the 'lobate stage' (ibid.), the ice dynamics were simplified and only the largest radial ice lobes and glacier tongues remained active in the lowlands.

The major stillstands of ice terminus or readvances of the ice margin were fixed by ice marginal zones. The reactivation of the ice lobes and glacier tongues was induced not only by climatic and environmental changes but was also caused by the melting and stagnation of the glacier in the adjacent upland areas that improved ice mass balance in the lowlands (Dreimanis and Zelčs 1995). As a result of melting of stagnant ice, a complex of superimposed glacial landforms in upland areas formed simultaneously with the glacial landforms continuum created by active ice fluctuations in lowlands. Later, related to melting of stagnant ice sedimentation and landform processes occurred in lowlands.

Five major ice marginal zones (in order of decreasing age - Dagda, Kaldabruña, Gulbene, Linkuva and Valdemārpils) can be distinguished in Latvia (Zelčs et al. 2011). These ice marginal zones can be tentatively correlated with Baltija (Pomeranian), South Lithuanian, Middle Lithuanian, North Lithuanian (Otepää) and Pandivere zones in the neighboring part of Estonia and Lithuania (see Guobytė and Satkūnas 2011; Kalm et al. 2011; Zelčs et al. 2011).

The Dagda phase marginal positions can only be traced in the south-eastern corner of Latvia, in the Latgale Upland. Here, the marginal zone is represented by the composite marginal ridges, which encompass the hypsometrically highest part of the upland, that is regarded as interlobate moulding. This phase replaces the Indra phase, defined by Āboltinšs et al. (1972), after improved topographical data became available.

The Kaldabruṇa marginal zone can be traced in Latgale, Augšzeme and Vidzeme Uplands. In the convergence zone of the ice masses of Zemgale and Lubāns lobes occurs the Sêlija Interlobate rigde. In Latgale and Vidzeme uplands the Kaldabruña marginal formations are located in the upglacier position from the central, hypsometrically highest zone where large-sized composite hummocks and plateau-like hills are dominant. In the Augšzeme Upland, this zone is composed of rather well-established marginal moraine ridges, eskers and tunnel valleys altered by subareal meltwater drainage. Further west across the LatvianLithuanian border, this marginal zone clearly coincides with the South Lithuanian marginal zone. Both these marginal zones are thought to represent the termination of the Lubāns and Polatsk (both draining from the Peipsi Ice Stream) ice lobes. There is only one ${ }^{10} \mathrm{Be}$ date, which corresponds to this glacial phase, and was taken from the boulder near the Latgale Upland northern margin well within the Kaldabruna glacial limit (Rinterknecht et al. 2006). This date of $15.5 \mathrm{ka}$ probably provides the minimum age of this phase (Zelčs et al. 2011).

During the Gulbene glacial phase, most part of the eastern Latvia upland area was ice 
free or covered by stagnant ice, while in western Latvia, only the southern part of the Western Kursa Upland became deglaciated (Zelčs et al. 2011). During this phase in south-eastern Latvia, the Lubāns ice lobe flowed south-westwards from the territory of Russia. Its termination is marked by the spectacular, up to $70 \mathrm{~m}$ high, composite marginal moraine ridge in the East-Latvian Lowland (Zelčs and Markots 2004; STOP 7: Fig. 7.1 in this volume). During this phase, the lowest marginal landform assemblage of the Latgale Upland was formed, as a termination of Lubāns and Polatsk ice lobes (Zelčs and Markots 2004). In northeastern Latvia, this phase can be drawn with some difficulties. During this stage, the Vidzeme Upland became ice free, and this phase is traced by the marginal moraine ridges and heavily glaciotectonised composite marginal ridges on its western, northern and north-eastern margins. In central Latvia, during this time, the Zemgale ice lobe was advancing in a highly divergent manner, far into the Middle Lithuanian lowlands.

The ${ }^{10} \mathrm{Be}$ dates from within the Gulbene glaciation stage range from (excluding extremes) 12.6 to $14.0 \mathrm{ka}$ (Rinterknecht et al., 2006), giving the average minimum age of the phase of ca. $13.5 \mathrm{ka}$. This corresponds rather well to the ${ }^{10} \mathrm{Be}$ dates from the Middle Lithuanian phase in neighbouring Lithuania (Rinterknecht et al. 2008). The minimum OSL age of the Gulbene ice-marginal zone is 14.5 to $15.5 \mathrm{ka}$, and it can be correlated with the Haanja zone in Estonia (Zelčs et al. 2011; Nartišs, Zelčs 2013). Single ${ }^{10}$ Be date of a boulder connected with the Gulbene ice-marginal zone in the Alūksne upland has yielded $15.290 \pm$ 980 yrs (Rinterknecht et al. 2006), thus indicating the start of ice retreat from the Gulbene icemarginal zone into the direction of the Middle Gauja Lowland.

During the Linkuva phase, glacial ice retreated furthernorth and most of eastern Latvia became ice free (Āboltinšs et al. 1972; Zelčs and Markots 2004). The Lubāns ice lobe disappeared, and only the Mudava (Velikoretsky) ice lobe was active in the extreme east of the East-Latvia Lowland. The ice-marginal position during this time is marked by the end-moraine chain, esker deltas and some short marginal meltwater valleys. In north-eastern Latvia, during this phase, the Burtnieks drumlin field was formed, terminating in the Veselava end-moraine chain (Āboltiņš et al. 1972). Central Latvia was occupied by the Zemgale ice lobe, producing the well-developed Linkuva end moraine arch in northern Lithuania and partly in Latvia (Āboltinš et al. 1972). During this phase, the western Latvia uplands became active ice free. The Usma ice lobe terminated as a series of glacier tongues, one of which ended in the Venta glacial lake (see Fig. 3 for location), therefore, position of the Usma ice lobe margin is very approximate. During this phase, the Baltic Ice Stream in the western Latvia coastal lowlands ceased to exist, and, instead, several ice tongues formed that protruded from west to east, leaving fragmented chains of end moraines on the slopes of the Western Kursa Upland. The ${ }^{10} \mathrm{Be}$ dates from boulders within the margins of the Linkuva phase give a wide distribution of ages (12.0-15.4 ka). Crossborder correlation in central Latvia is straightforward, while in western Latvia, the Linkuva icemarginal formations are thought to correlate with the Pajūris ice-marginal formation zone (Guobyte and Satkūnas, 2011) but are hard to trace. In Estonia, the Linkuva glacial phase marginal formations can rather be correlated with the Otepää ice-marginal zones but here the cross-border correlation is again difficult.

The Valdemārpils glacial phase is the latest deglaciation stage of the Fennoscadian Ice Sheet in Latvia, and its limit stretches along the Baltic Ice Lake and modern sea coast. Inland, east and west of the Gulf of Rìga, the Valdemārpils phase is marked by a chain of relatively low-marginal ridges and end moraines. In central and north-western Latvia, tracing this glacial limit is quite problematic because most of the glacial landscape is smoothed or eroded by Late-glacial meltwater basins and Litorina Sea. The Valdemārpils ice-marginal zone can logically be correlated to the Sakala ice marginal zone in Estonia. There are no reliable dates 
corresponding to this ice-marginal zone; being located between the Otepää and Pandivere icemarginal zones, sets the time limits for this stage between $14.5 \mathrm{ka}$ (Lasberg and Kalm 2013) and 14.0 ka (Vassiljev and Saarse 2013).

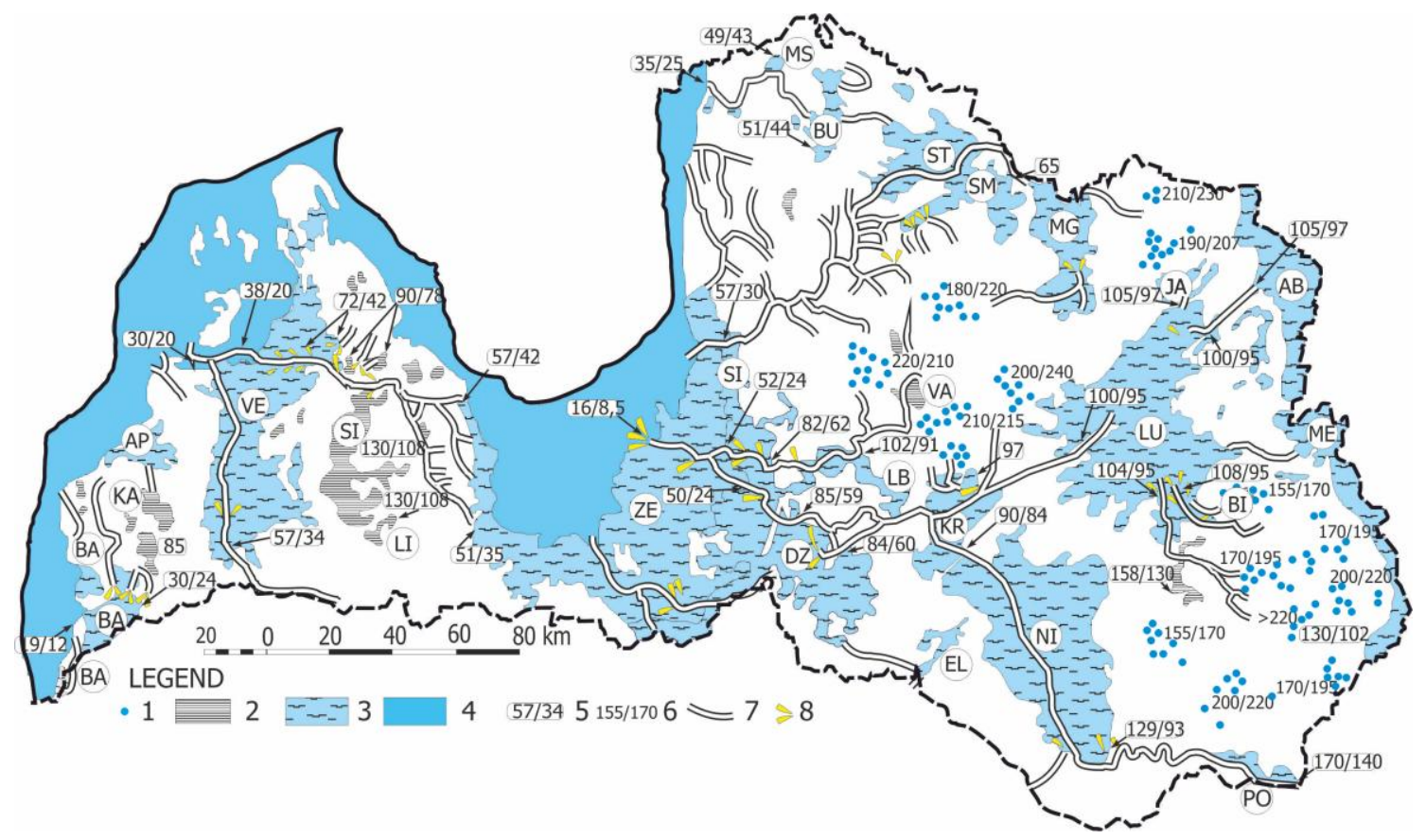

Fig. 3. Distribution of ice-dammed lakes and glaciolacustrine deposition sites in Latvia (modified after Zelčs and Markots 2004).

Legend: 1 - accumulation of glaciolacustrine sediments on hilltops; 2 - ice dammed lakes in glacial uplands: KA - Kalvene, SI - Saldus-Imula, LI - Lielauce, VA - Valole, BI - Biži; 3 - meltwater basins in glacial lowlands: BA - Bārta, AP - Apriķi, VE - Venta, ZE - Zemgale, SI - Silciems; DZ - Daudzeva, LB - Lobe, EL - Elkšņi, KR - Krustpils, NI - Nīcgale, PO - Polatsk, ME - Mērdzene, LU - Lubāns, JA - Jaunanna, AB - Abrene, MG Middle Gauja, SM - Smiltene, ST - Strenči, BU - Burtnieks, MS - Middle Salaca, 4 - Baltic Ice Lake; 5 maximum/minimum shorelines a.s.l.; 6 - elevations of plateau-like hills; 7 - largest meltwater and remnant lake drainage pathways; 8 - ancient deltas.

Due to effect of the flat topography and the dominant sloping down of the glacier bed surface towards the retreating ice margin, the meltwater and proglacial waters could not drain freely and flooded relatively large areas of glacial lowlands (Fig. 3). Drainage of these glacial lakes was often gradual, via lateral and/or proglacial meltwater channels, but sometimes during large lake drainage events this release was catastrophic. As a result in watershead areas deeply-incised and wide proglacial spillways were formed (Fig. 3). The width of the largest spillway valleys (e.g., Upper Daugava and Lower Gauja) reaches $2.5-3 \mathrm{~km}$, the depth is up to $90 \mathrm{~m}$. Meltwater discharge resulted also in intense deposition of sediments either as deltas in the hipsometrically lower position located lakes or glaciofluvial fans in supra-aquatic environment.

The onset of the Late Weichselian glaciation in Latvia has not been reliably dated, but the available OSL dates from western, central and eastern Latvia suggest that ice masses invaded the territory no earlier than 24-25 ka. Deglaciation of the territory was started in Daniglacial time, about 18,000 years BP. The ice sheet finally retreated from Latvia during the Late Weichselian Late-glacial Interstadial, about 14 ka B.P. Therefore the possible duration of the Late Weichselian glaciation of Latvia ranges between ca. 9 and $10 \mathrm{ka}$ (Zelčs et al. 2011). Periglacial conditions persisted until the beginning of the Holocene. 
References

Āboltiņš, O.P. 1989. Gliatsiostruktura i lednikovy morfogenez [Glaciotectonic structure and glacial morphogenesis]. Zinātne, Rīga, 284 pp. (In Russian).

Āboltiņš, O., Dreimanis, A. 1995. Glacigenic deposits in Latvia. In: Ehlers, J., Kozarski, S., Gibbard, P. (eds.), Glacial Deposits in North-East Europe. Balkema, Rotterdam/Brookfield, pp. 105-113.

Āboltiņš, O., Veinbergs, I., Danilāns, I., Stelle, V., Straume, J., Eberhards, G., Juškevics, V., Jaunputninš, A. 1972. Main features of glacial morphogenesis and peculiarities of deglaciation of the last glaciation in the territory of Latvia. In: Danilāns, I., Āboltiņš, O. (eds.), Putyevoditel polevogosimpoziuma III Vsesoyuznogo mezhvedomstvennogo soveschaniya po izucheniyu krayevykh obrazovaniy materikovogo oledeneniya. Zinatne, Riga, pp. 3-16 (in Russian).

Arppe, L., Karhu, J.A. 2010. Oxygen isotope values of precipitation and the thermal climate in Europe during the middle to late Weichselian ice age. Quaternary Science Reviews, 29 (9-10), 1263-1275.

Danilāns, I. 1973. Quaternary Deposits of Latvia. Zinatne, Riga, 312 pp.(In Russian).

Danilāns, I., Dzilna, V., Stelle, V. 1964. The section Zidini. In: Danilans, I. (ed.), Questions of Quaternary Geology, III, Publishing House of Academy of Sciences Latvian SSR. Rīga, 63-140 pp. (in Russian, with Endlish summary).

Dreimanis, A., Kārklinš, O. 1997. Latvia. In: Moores, E., Fairbridge, R. (eds.), Encyclopedia of European and Asian Regional Geology. Chapman \& Hall, pp. 498-504.

Dreimanis, A., Zelčs, V. 1995. Pleistocene stratigraphy of Latvia. In: Ehlers, J., Kozarski, S., Gibbard, P. (eds.), Glacial Deposits in North-East Europe. Balkema, Rotterdam/Brookfield, pp. 105-113.

Guobyte, R., Satkūnas, J. 2011. Chapter 19: Pleistocene Glaciations in Lithuania. In: Ehlers, J., Gibbard, P.L., Hughes, P.D. (eds.), Quaternary glaciations - extent and chronology. A closer look. Developments in Quaternary Science, 15. Elsevier, pp. 231-246.

Kalm, V., Raukas, A., Rattas, M., Lasberg, K. 2011. Chapter 8: Pleistocene Glaciations in Estonia. In: Ehlers, J., Gibbard, P.L., Hughes, P.D. (eds.), Quaternary glaciations - extent and chronology. A closer look. Developments in Quaternary Science, 15. Elsevier, pp. 95-104.

Kalniņa, L., Strautnieks, I., Cerina, A. 2013. A Cromerian Complex palaeolake sediment sequence from the Zidini site, south-eastern Latvia. Quaternary International, 2013, 98-109.

Lasberg, K., Kalm, V. 2013. Chronology of Late Weichselian glaciation in the western part of the East European Plain. Boreas, 42(4), pp. 995-1007.

Molodkov, A., Dreimanis, A., Āboltinš̌, O., Raukas, A. 1998. The age of Portlandia arctica shells from glacial deposits of Central Latvia: an answer to a contraversy on the age and genesis of their enclosing sediments. Quaternary Geochronology, 17, 1077-1094.

Nartišs, M., Zelčs, V. 2013. Was the Middle Gauja lowland ice free during Linkuva time? In: Palaeolandscapes from Saalian to Weichselian, South Eastern Lithuania. Abstracts of International Field Symposium. Lithuanian Geological Survey, Vilnius-Traka, pp. 71-72.

Rinterknecht, V.R, Bitinas, A, Clark, P.U, Raisbeck, G.M, Yiou, F., Brook, E.J. 2008. Timing of the last deglaciation in Lithuania. Boreas, 37(3), 426-433.

Rinterknecht V. R., Clark P. U., Raisbeck G. M., Yiou F., Bitinas A., Brook E. J., Marks L., Zelčs V., Lunkka J.P., Pavlovskaya I. E., Piotrowski J. A., Raukas A. 2006. The Last Deglaciation of the Southeastern Sector of the Scandinavian Ice Sheet. Science, 311, 10 March 2006, 1449-1452.

Saks, T., Kalvāns, A., Zelčs, V. 2012. OSL dating of Middle Weichselian age shallow basin sediments in Western Latvia, Eastern Baltic. Quaternary Science Reviews, 44(1), 60-68, http://dx.doi.org/10.1016/j.quascirev.2010.11.004.

Ukkonen, P., Lõugas, L., Zagorska, I., Lukševiča, L., Lukševičs, E., Daugnora, L., Junger, H. 2006. History of the reindeer (Rangifer tarandus) in the eastern Baltic region and its implications for the origin and immigration routes of the recent northern European wild reindeer populations. Boreas, 35(2), 222-230.

Vassiljev, J., Saarse, L. 2013. Timing of the Baltic Ice Lake in the eastern Baltic. Bulletin of the Geological Society of Finland, 85, pp. 9-18.

Zelčs, V., Dreimanis, A. 1997. Morphology, internal structure and genesis of the Burtnieks drumlin field. Journal of Sedimentary Geology, 111 (1-4), 73-90.

Zelčs, V., Markots, A. 2004. Deglaciation history of Latvia. In: Ehlers, J., Gibbard, P. L. (eds.), Quaternary Glaciations - Extent and Chronology. Part I: Europe. Developments in Quaternary Sciences, 2. Elsevier, Amsterdam, pp. 225-243.

Zelčs, V., Markots, A., Nartišs, M., Saks, T. 2011. Chapter 18: Pleistocene Glaciations in Latvia. In: Ehlers, J., Gibbard, P.L., Hughes, P.D. (eds.), Quaternary glaciations - extent and chronology. A closer look. Developments in Quaternary Science, 15. Elsevier, pp. 221-229. 


\section{INQUA Peribaltic Regional Working Group Symposium Eastern and Central Latvia, August 17-22, 2014}

\section{EXCURSION GUIDE}




\title{
STOP 1: Lower Gauja spillway valley at Sigulda
}

\author{
Māris Krievāns, Vitālijs Zelčs and Māris Nartišs
}

University of Latvia

The stop $\left(24^{\circ} 50^{\prime} 2 " \mathrm{E}, 57^{\circ} 10^{\prime} 15^{\prime \prime} \mathrm{N}\right.$, for location see Fig. 1.1) at the Krimulda Castle ruins in Sigulda introduces the geological structure, morphology and formation of the River Gauja valley and slope processes between the towns of Valmiera and Vangaži. This stretch of the river valley, also known as the Lower Gauja spillway valley, is about $110 \mathrm{~km}$ long. The spillway is confined to an ancient buried valley incised into Middle and Upper Devonian sedimentary rock (Pērkons 1947). The oversized river valley is $1-2.5 \mathrm{~km}$ wide and reaches a depth of $25 \mathrm{~m}$ near Valmiera, 35-40 $\mathrm{m}$ in the vicinity of Césis and $85 \mathrm{~m}$ at Sigulda. The floor of the bedrock within the valley lies at $17-18 \mathrm{~m}$ a.s.l. near Valmiera, $12 \mathrm{~m}$ b.s.l. in the vicinity of Cēsis and more than $50 \mathrm{~m}$ b.s.l. at Sigulda (Fig. 1.2). It is significant that downstream of Cēsis the ancient valley is carved into weakly-cemented and/or soft Devonian terrigenous rock that runs along the lithological boundary with carbonate rock.

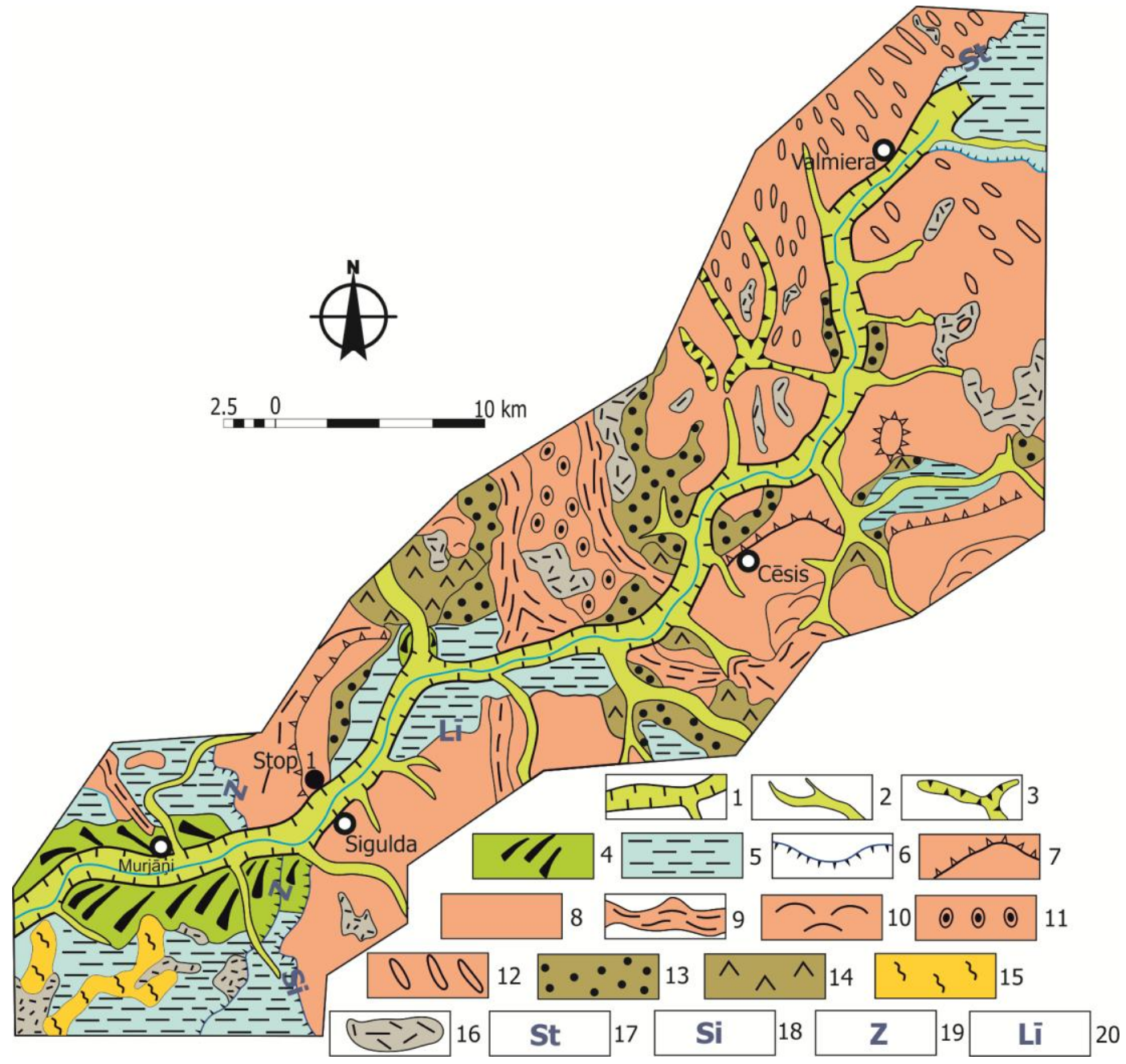

Fig. 1.1. Geomorphological map of the River Gauja valley and the adjacent area between Valmiera town and Murjān,i village. 1 - Lower Gauja spillway valley; 2 - valleys of tributaries; 3 - largest gullies; 4 - late-glacial delta plains; 5 - glaciolacustrine plains; 6 - ancient shorelines of glacial lakes; 7 - ice-contact and bedrock scarps; 8 - till plains; 9 - ice marginal ridges; 10 - morainic hills; 11 - cupola-like hills; 12 - drumlins; 13 glaciofluvial plains; 14 - kames; 15 - inland dunes; 16 - mires; 17 - Strenči proglacial lake; 18 - Silciems icedammed lake; 19 - Zemgale ice-dammed lake; 20 - Ligatne ice-dammed lake; black circle - location of the stop. 
According to Āboltinšs (1971), the buried valley was formed before the Saalian glaciation. This conclusion is based on the occurrence of the lower till bed on the surface of the Middle Devonian sandstone at the base of the buried valley near the towns of Valmiera, Cēsis and Sigulda, and Murjāni village (Figs. 1.2 and 1.3). The cross-section of the Lower Gauja spillway valley is asymmetrical, with a general prevalence of erosional terraces. These terraces represent the Sigulda terrace spectrum of the Gauja River valley (Āboltinšs 1971).

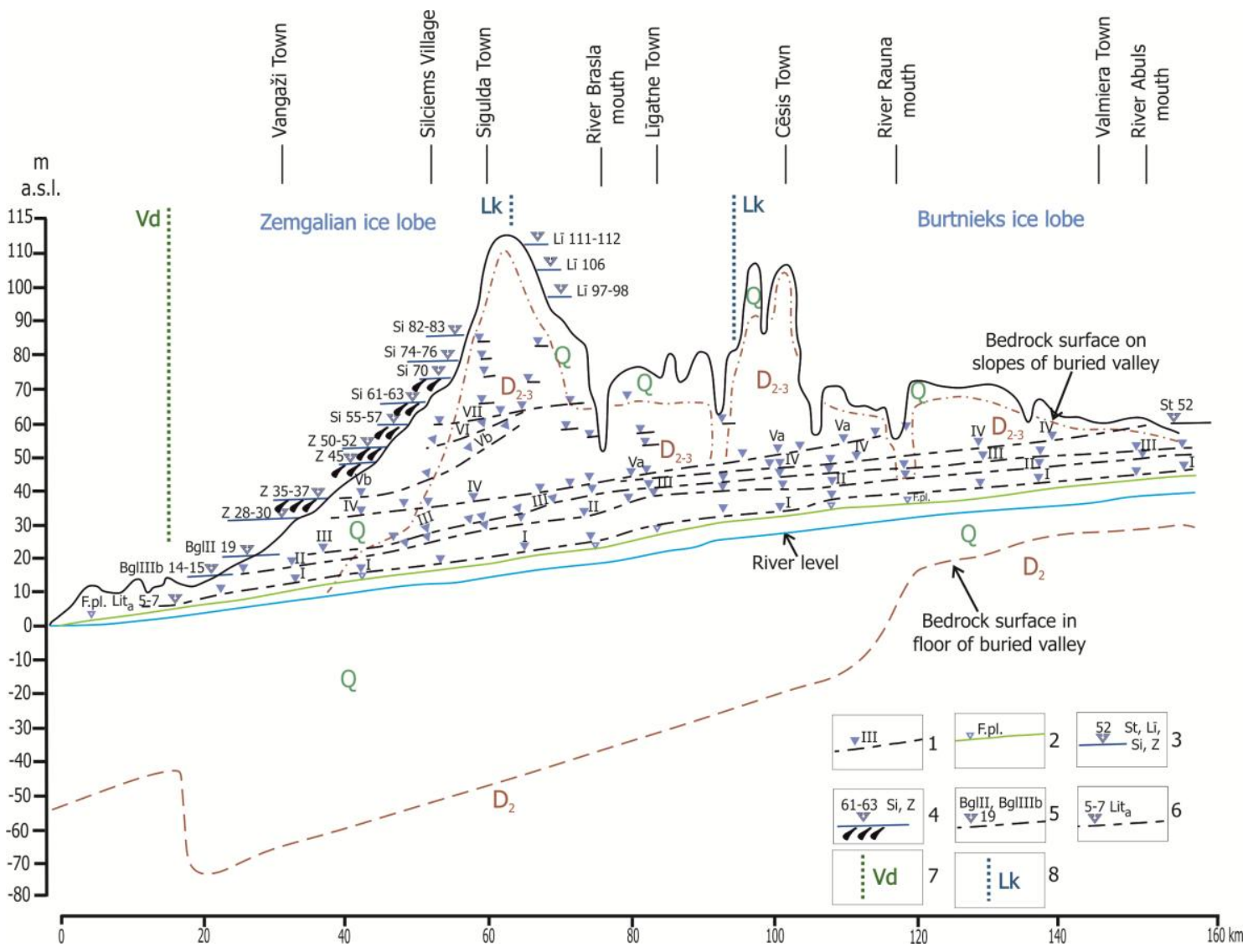

Fig. 1.2. Longitudinal profile of valley and terraces of the River Gauja downstream of the Strenči meltwater basin. 1 - terrace and its symbol; 2 - floodplain; 3 - shoreline elevation and symbols of glacial lakes: St - Strenči meltwater basin, Lī - Līgatne ice-dammed lake; $\mathrm{Si}$ - Silciems ice-dammed lake, Z - Zemgale ice-dammed lake; 4 - elevations of late-glacial delta levels in Silciems and Zemgale ice-dammed lakes; 5 - elevation and symbol of the Baltic Ice Lake stage Bgl II and phase $\mathrm{Bgl} \mathrm{III}_{\mathrm{b}} ; 6$ - elevation and symbol of the Littorina Sea maximum transgression phase $\left(\mathrm{Lit}_{\mathrm{a}}\right) ; 7$ - ice marginal position of the Valdemārpils phase; 8 - ice marginal position of the Linkuva phase.

On the basis of geological and geomorphological studies Āboltinšs (1971) distinguished seven terrace levels in the Gauja River valley at Sigulda, but some terrace remnants are located on the upper part of the valley slopes upstream and downstream of this town, at a higher elevation than terrace VII (Fig. 1.3). According to Āboltinšs $(1969,1971)$, the highest terraces of the upper complex (terraces VI and VII) were formed by meltwater streams, which flowed from melting dead ice and small proglacial lakes, located in areas near the valley, into the Silciems ice-dammed lake. Terraces IV and V were produced as a result of water drainage from Strenči meltwater basin, located in the topographically lowest part the Northern Vidzeme Lowland, into the Zemgale ice-dammed lake, which partly occupied the lower part of the Central Latvian Lowland.

The latest studies of the Ligatne ice-dammed lake terraces between Sigulda and the River Amata testify that the highest terraces of the upper complex of the River Gauja 
represent the shorelines of an ice meltwater basin. Terraces developed during several phases of incision are related to the evolution of the Ligatne ice-dammed lake. Next to the Ratnieki Conference and Recreational Centre of the University of Latvia, situated on a glaciolacustrine plain, the terraces of the Ligatne ice-dammed lake can be traced at 111-112 m, $106 \mathrm{~m}$ and 97$98 \mathrm{~m}$ a.s.l. (Fig. 1.2). Terraces composed of fine-grained sand, silt and clay are traceable at levels of 75, 61-62 and 51-52 $\mathrm{m}$ a.s.l. The thickness of the glaciolacustrine sediments varies from some tens of centimetres to a few metres. The River Gauja terraces formed by streams are traceable at levels below $50 \mathrm{~m}$ a.s.l.

Both highest terraces of the lower complex (terraces III and II) are related to levels of the Baltic Ice Lake (stage $\mathrm{Bgl}$ II and phase $\mathrm{Bgl} \mathrm{III}_{\mathrm{b}}$ ), whereas terrace I conjugates with the Littorina Sea phase $\mathrm{Lit}_{\mathrm{a}}$ level (Āboltiņš 1971; Grīnbergs 1957).

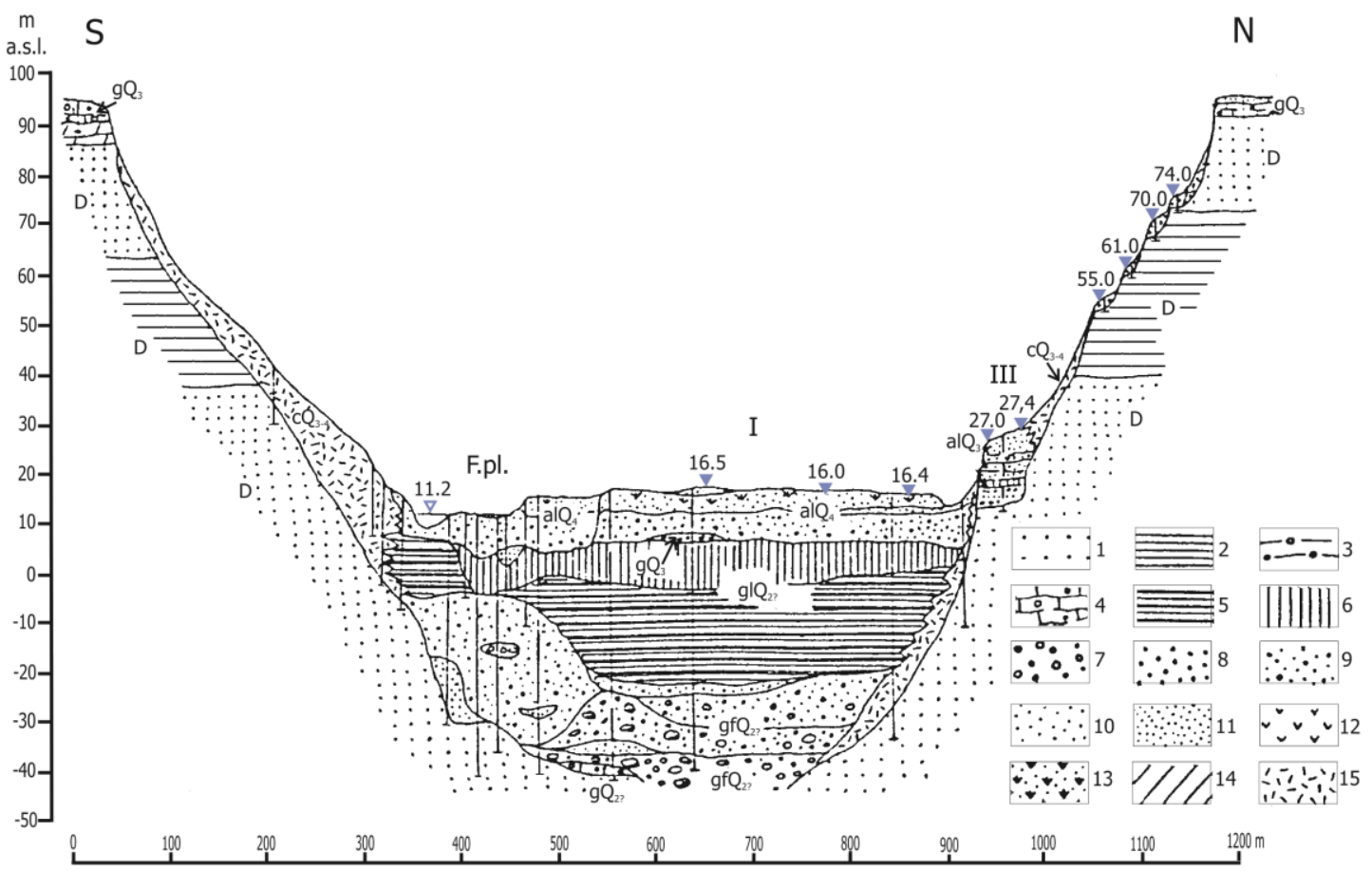

Fig. 1.3. Cross-section of the ancient River Gauja valley at the town of Sigulda (modified after Āboltinšs 1971 and Pērkons 1947). 1 - Devonian sandstone; 2 - Devonian clay and siltstone; 3 - Saalian (?) till (gQ2); 4 Weichselian reddish brown sandy-clayey basal till (gQ3); 5 - varved clay (glQ2?); 6 - silt (glQ3 and alQ4); 7 pebbles with gravel (alQ3 and alQ4); 8 - gravel (alQ3 and alQ4); 9 - sand with gravel (alQ3 and alQ4); 10 fine-grained sand (alQ3 or alQ4); 11 - silty fine-grained sand (alQ3 or alQ4); 12 - peat (pQ4); 13 - disseminated organic matter in sand (alQ4); 14 - silty loam (alQ4); 15 - sandy colluvium (cQ3-4).

Formation of the stretch of the River Gauja between the towns of Valmiera and Vangaži began after the ice retreat from the marginal zone of the Linkuva phase (North Lithuanian) at least by about 15.2 cal. ka BP (calibrated from $13.0 \mathrm{ka}$ BP using the IntCal09 calibration curve). Terraces VII to IV were apparently formed before the Allerød. According to Stelle et al. (1975 a, b), the radiocarbon age obtained from organic debris at the Viesulenni farmhouse is $11,270 \pm 230{ }^{14} \mathrm{C}$ yrs BP (Ri-105) and $11,114 \pm 350{ }^{14} \mathrm{C}$ yrs BP (Ri-74), and peat sediments at the Līči Sanatorium have been dated to $10,535 \pm 250{ }^{14} \mathrm{C}$ yrs BP $(\mathrm{Ri}-33)$ and $10,282 \pm 250{ }^{14} \mathrm{C}$ yrs BP (Ri-33A). These data refer to the formation of terraces III and II during the Allerød and Younger Dryas. Terrace I developed during a relatively long time interval of the Holocene (from the Boreal until the Subboreal). All the terraces of the uppermost complex have been generated under conditions of continuous intensive downcutting. The alluvium of the lower terrace complex and floodplain consists of two members, i.e. includes both channel and 
floodplain facies. The thickness of the alluvium reaches up to 8-10 $\mathrm{m}$ and more in places. The lowest part of the Gauja valley is occupied by an aggradational floodplain (Figs. 1.2 and 1.3).

The slopes of the Lower Gauja spillway valley are also dissected by numerous gullies and valleys of tributaries, particularly in the stretch between the towns of Ligatne and Sigulda. The slopes of the River Gauja and its tributaries display numerous landslides, suffosion caves and grottoes, along with typical and valley-like gullies. Alluvial-proluvial fans, and cave and grotto floors are related to different terrace levels, which suggests successive formation of these landforms in the course of development of the River Gauja valley.

\section{References}

Āboltiņš, O. 1969. The types of alluvium of the holocene terraces of the Gauja river valley. In: Danilāns, I. (ed.), Questions of Quaternary geology, IV. Publishing House „Zinātne”, Rīga, pp. 121-140 (in Russian, with English summary).

Āboltiņš, O. 1971. Razvitije dolini reki Gauya [Development of the River Gauja valley]. Zinātne, Rīga, 105 pp. (In Russian)

Grīnbergs, E. 1957. Pozdnelednikovaja i poslelednikovaja istorija poberezja Latvijskoj SSR [Late-glacial and postglacial history of the coastal plains of Latvian SSR]. Publishing House of Academy of Sciences of Latvian SSR, Rīga, 122 pp. (In Russian)

Stelle, V., Savvaitov, A.S., Veksler, V.S. 1975a. Datirovaniye pleistotsenovykh otlozheniy na territorii Latvii [Dating of Pleistocene deposits in the territory of Latvia]. In: Savvaitov, A.S., Veksler, V.S. (eds), Opyt $i$ metodika izotopno-geokhimicheskikh issledovaniy v Pribaltike i Belorussii. VNIIMORGEO, Riga, pp. 8081 (in Russian).

Stelle, V., Veksler, V.S., Āboltiņš O. 1975b. Radiouglerodnoye datirovaniye allyuvialnykh otlozheniy srednego techeniya reki Gauyi [Radiocarbon dating of the alluvial deposits of the Middle course of the River Gauya]. In: Savvaitov, A.S., Veksler, V.S. (eds), Opyt i metodika izotopno-geokhimicheskikh issledovaniy v Pribaltike i Belorussi. VNIIMORGEO, Riga, p. 87-88 (in Russian).

Pērkons, V., 1947. Gaujas senielejas ǵeologiskais šķērsgriezums pie Siguldas, Valmieras un Murjāṇiem. In: Galenieks, P. (ed.), Latvijas PSR Zinātņu Akadēmijas Ģeologijias un Ģeogrāfijas Institūta Raksti, 1, 143147. Publishing House of Academy of Sciences of Latvian SSR, Rīga. 


\section{STOP 2: Late-glacial and postglacial environmental changes, Lake Āraiši, Vidzeme Upland}

\section{Normunds Stivriņ̌s}

Tallinn University of Technology, Estonia

Palaeoecological records preserved in sedimentary deposits can provide a unique insight into the nature of past ecosystems. Moreover, the rapid fluctuations in climate and environmental conditions during the Late Glacial make this time period an important focus of study (Lowe et al. 1999). Relatively small, closed lakes are sensitive to these changes and integrate information about such variations in the lake basin and its catchment (Seppä et al. 2009). Although studies on the Late Glacial in the eastern Baltic area go back more than a century, focussing on ice-recession lines and chronology (Kalm 2012; Zelčs and Markots 2004; Zelčs et al. 2011), there is a lack of studies based on lake sediments. Thus, uncertainty remains with respect to the relative timing of environmental changes in relation to climatic fluctuation during the Late Glacial.

Lake Âraiši is located $\left(57^{\circ} 15^{\prime} \mathrm{N}, 25^{\circ} 17^{\prime}\right.$ E) in central Latvia (Fig. 2.1), on the northwestern edge of the Vidzeme Upland, $6 \mathrm{~km} \mathrm{~S}$ of the town of Cēsis, at an elevation of $120.2 \mathrm{~m}$ a.s.l. The lake covers 32.6 ha, with a flow-through hydrological regime. It has a mean and maximum depth of 4 and $12.3 \mathrm{~m}$, respectively. The size of the lake's catchment area is $\sim 10 \mathrm{~km}^{2}$. The surrounding undulating landscape consists predominantly of open fields and meadows.

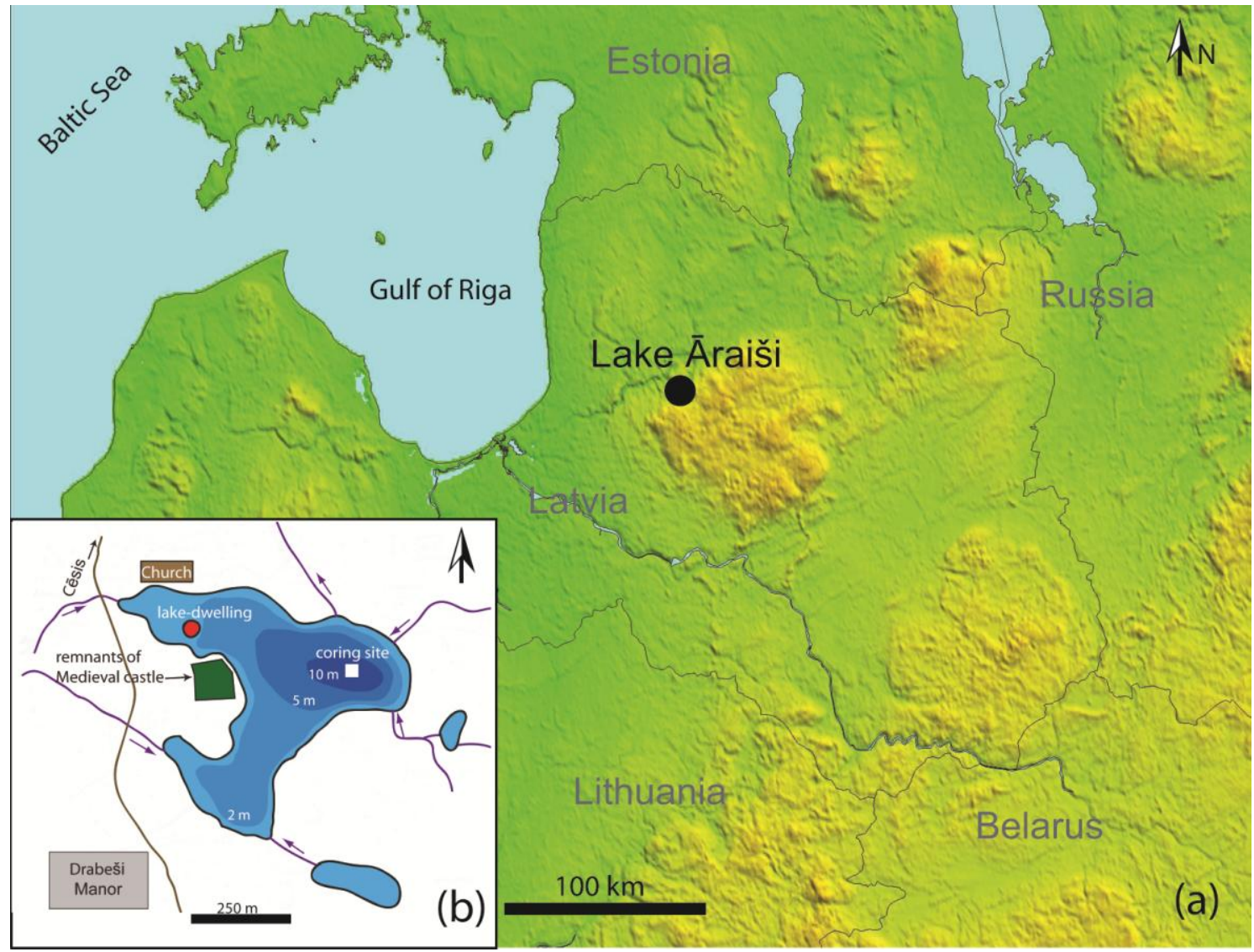

Fig. 2.1. The study area: (a) location of Lake Āraiši; (b) coring site and setting of the lake.

The present-day topography was largely formed during the Late Weichselian glaciation and deglaciation (Zelčs and Markots 2004; Zelčs et al. 2011). In the Lake Āraiši area the 
bedrock surface of Devonian siliciclastic sedimentary rock is overlain by $80 \mathrm{~m}$ of glacial deposits. Although the site is located in the continental-maritime transitional zone, the climate may be characterized as moderately continental. The mean annual precipitation is $700-800$ $\mathrm{mm}$, with mean temperatures in January and July of $-6^{\circ} \mathrm{C}$ and $+16.5^{\circ} \mathrm{C}$, respectively.

Coring for laboratory analyses was undertaken using a 1-m-long Russian-type corer, a 12.4-m-long sediment sequence being recovered at the deepest point of the lake $(12.3 \mathrm{~m})$ from the ice-covered surface in March 2012 (See Fig. 2.1 (b) for location). Sediment cores were documented and packed in film-wrapped 1-m plastic PVC semi-tubes. Loss on ignition (LOI) analysis was performed at 2-cm continuous intervals. Samples were dried overnight at $105^{\circ} \mathrm{C}$, combusted at $550^{\circ} \mathrm{C}$ for 4 hours to determine the organic matter $(\mathrm{OM})$ content of the sediment and the ignition residue was estimated as the mineral matter (MM) content of the sediment. Magnetic susceptibility (MS) was measured with a Bartington MS2E meter (Nowaczyk 2001). In addition, pollen and non-pollen palynomorphs were identified. For the purpose of cryptotephra (distal tephra) investigation, sampling for rhyolitic glass shard extraction was carried out as described by Turney (1998) and Blockley et al. (2005). Rangefinder samples were taken at 5-cm intervals. After removal of OM, the samples were sieved, and particles between 25 and $80 \mu \mathrm{m}$ were centrifuged in sodium polytungstate (SPT) to float rhyolitic shards from the background mineral matrix. Shards were identified optically under a polarizing light microscope.

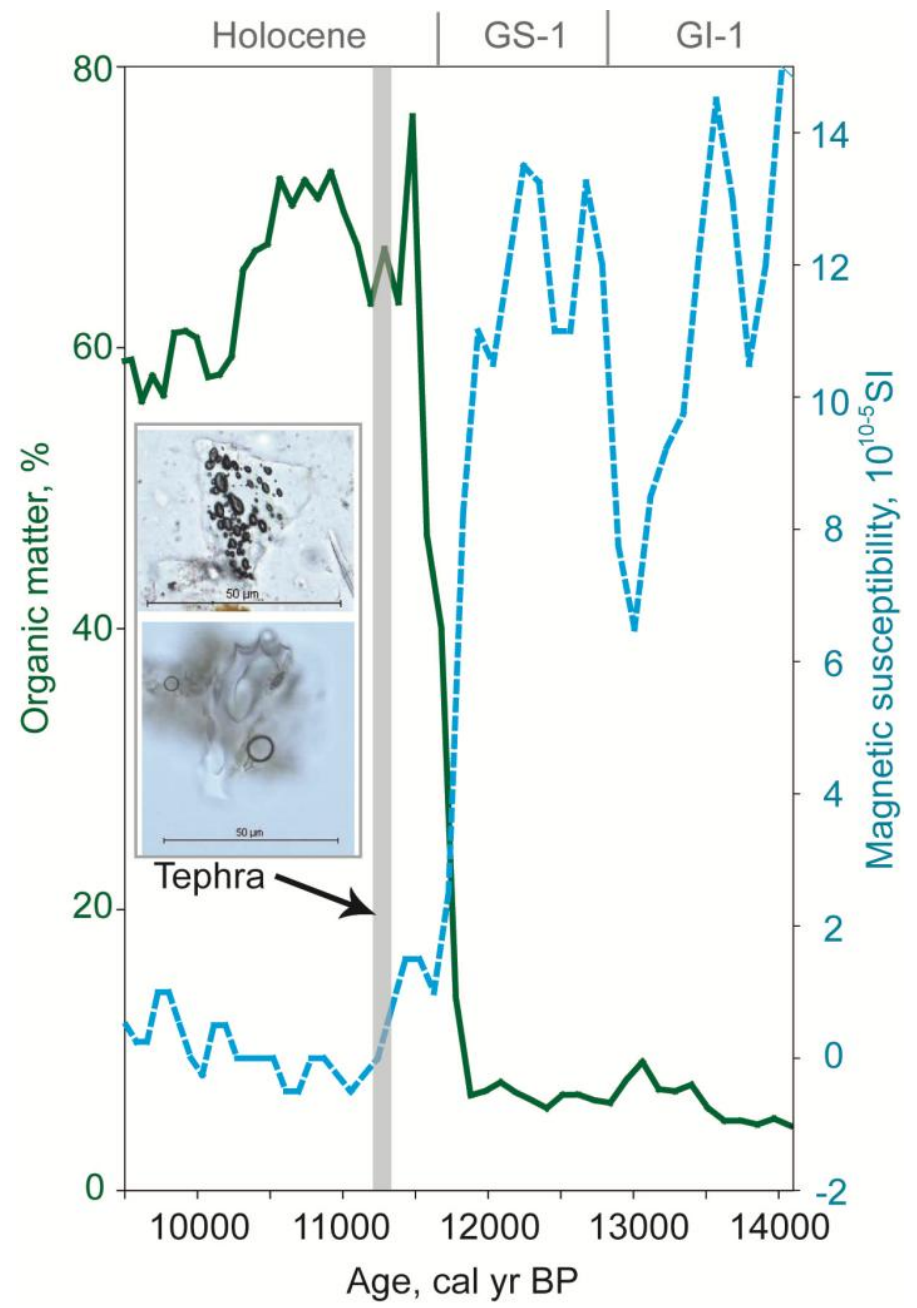

Fig. 2.2. Organic matter and magnetic susceptibility for Late Glacial sequence from Lake Āraiši. Grey vertical line indicates location of microtephra horizon; two pictures of microtephra are given at left. 
The chronology for the whole sequence was based on $12{ }^{14} \mathrm{C}$ conventional and five ${ }^{14} \mathrm{C}$ AMS dates, and the chronology of the upper part on the distribution of spheroidal fly-ash particles (Rose et al. 1990; Heinsalu and Alliksaar 2009). Samples were dated at the Institute of Geology at the Tallinn University of Technology (Tln) in Estonia and Poznan Radiocarbon Laboratory (Poz) in Poland.

The results revealed that the Lake Āraiši depression was ice-free at least by $14,100 \mathrm{cal}$ yr BP. In addition, macrofossil finds suggest the development of vegetation in the surroundings and the start of $\mathrm{OM}$ accumulation in Lake Âraiši from that time onwards (Fig. 2.2). These dates show good agreement with results of regional studies (Amon et al. 2014; Veski et al. 2012) and support the idea of relatively rapid ice retreat from the eastern Baltic. Moderately higher OM and lower MS values indicate changes in vicinity corresponding to the warmer period (Allerød) (Lowe et al. 2008) at the end of GI-1 (Fig. 2.2). Following cooling at GS-1 (Younger Dryas) there was increased inwash of MM into the lake, as also indicated by the elevated MS. Rapid accumulation of $\mathrm{OM}$ at the Pleistocene-Holocene boundary indicates major changes in the surroundings of Lake Āraiši. In a study on Lake Lielais Svētini (eastern Latvia) Veski et al. (2012) reported an accumulation of OM-rich gyttja and forest re-expansion at the start of the Holocene warming.

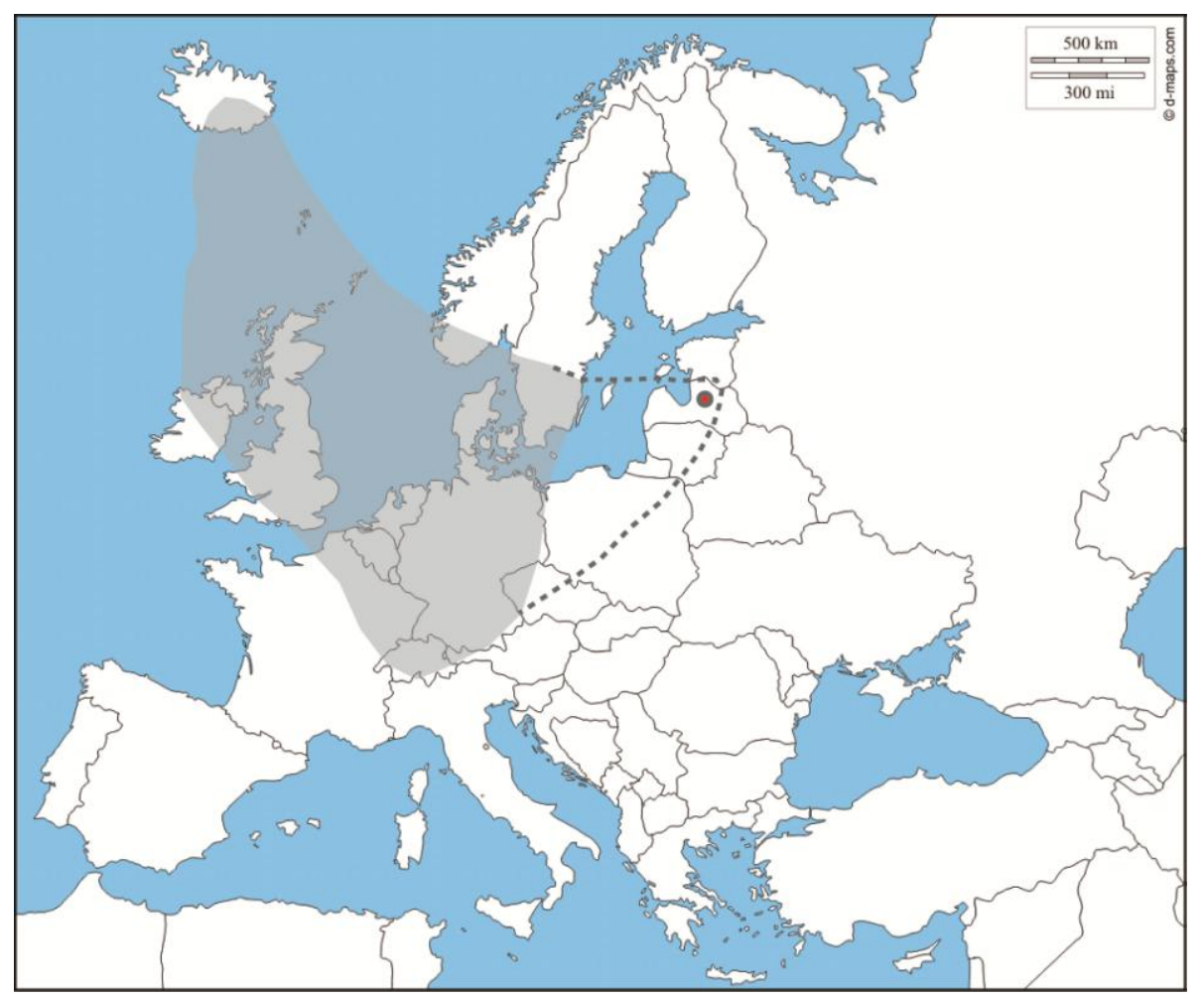

Fig. 2.3. Tephrostratigraphic time-slice map showing the currently known distribution of fallout deposits of the Hässeldalen and Askja tephras. Map redrawn after Lane et al. (2012). Grey shaded area - dispersal envelope of tephra layers; dotted line - possible dispersal of tephra; circle - location of Lake Āraiši.

Furthermore, the finds of microtephra shards (Fig. 2.3) at a depth of 23.40-23.45 m $(11,050-11,300$ cal yr BP) could be used as a time-marker horizon in future. However, a greater concentration of shards should be obtained and geochemical analyses performed. The Hässeldalen tephra $(11,360-11,300 \mathrm{cal}$ yr BP) is the possible source for this tephra. Lilja et al. (2013) point out that, due to several eruptive events and stratigraphical proximity, the 10-ka Askja could be another possible source. Even though there are two possible sources, this discovery offers great potential as a regional isochrone, which could be used to synchronize the chronology and sediment records of the central and northern European deglaciation. 
The vicinity of Lake Āraiši was forested and sparsely populated, and the first cereal pollen grains showing human presence appear only at AD 400. During the Migration Period (AD 400-800) new tribal groups may have invaded, building the fortified lake-dwelling in A.D. 780 (Meadows and Zunde in press), associated with the most significant changes in landscape during the last 2000 years. The lake-dwelling was inhabited by Late Iron Age Latgallian tribes. During the early $13^{\text {th }}$ century, the Latgallian territory was conquered by the Order of Swordbrothers (the later Livonian Branch of the Teutonic Order), and the lakedwelling was destroyed. Nowadays the lake dwelling has been reconstructed and serves as an archaeological open-air museum.

\section{References}

Amon, L., Veski, S., Vassiljev, J. 2014. Tree taxa immigration to the eastern Baltic region, southeastern sector of Scandinavian glaciation during the Late-glacial period (14,500-11,700 cal. B.P.). Vegetation History and Archaeobotany, 23, 207-216.

Blockley, S.P.E., Pyne-O’Donnell, S. D.F., Lowe, J.J., Matthews, I.P., Stone, A., Pollard, A.M., Turney, C.S.M., Molyneux, E.G. 2005. A new and less destructive laboratory procedure for the physical separation of distal glass tephra shards from sediments. Quaternary Science Reviews, 24, 1952-1960.

Heinsalu, A., Alliksaar, T. 2009. Palaeolimnological assessment of environmental change over the last two centuries in oligotrophic Lake Nohipalu Valgjärv, southern Estonia. Estonian Journal of Earth Sciences, $58,124-132$.

Kalm, V. 2012. Ice-flow pattern and extent of the last Scandinavian Ice Sheet southeast of the Baltic Sea. Quaternary Science Reviews, 44, 51-59.

Lane, C.S., De Klerk, P., Cullen, V.L. 2012. A tephrochronology for the Lateglacial palynological record of the Endinger Bruch (Vorpommern, northe-east Germany). Journal of Quaternary Science, 27, 141-149.

Lilja, C., Lind, E.M., Morén, B., Wastegård, S. 2013. A Lateglacial-early Holocene tephrochronology for SW Sweden. Boreas, 42, 544-554.

Lowe, J. J., Birks, H. H., Brooks, S. J., Coope, G. R., Harkness, D. D., Mayle, F. E., Sheldrick, C., Turney, C.S.M., Walker, M.J. 1999. The chronology of palaeoenvironmental changes during the last glacialHolocene transition; towards an event stratigraphy for the British Isles. Journal of the Geological Society of London, 156, 397-410.

Lowe, J.J., Rasmussen, S.O., Bjorck, S., Hoek, W.Z., Steffensen, J.P., Walker, M.J.C., Yu, Z.C., INTIMATE Group. 2008. Synchronisation of palaeoenvironmental events in the North Atlantic region during the Last Termination: a revised protocol recommended by the INTIMATE group. Quaternary Science Reviews, $27,6-17$

Meadows, J., Zunde, M. in press. A lake-fortress, a floating chronology, and an atmospheric anomaly: the surprising results of a radiocarbon wiggle-match from Äraiši, Latvia. Geochronometria, xx-xx.

Nowaczyk, N.R. 2001. Logging of magnetic susceptibility. In: Smol, J.P., Last, W.M. (eds),Tracking Basin Analysis, Coring and Chronological Techniques. Environmental Change Using Lake Sediments, 1. Kluwer Academic Publishers, Dordrecht, pp. 155-170.

Rose, N.L. 1990. A method for the selective removal of inorganic ash particles from lake sediments. Journal of Paleolimnology, 4, 61-68.

Seppä, H., Bjune, A.E., Telford, R.J., Birks, H.J.B., Veski, S. 2009. Last nine-thousand years of temperature variability in Northern Europe. Climate of the Past, 5, 523-535.

Turney, C.S.M. 1998. Extraction of rhyolitic component of Vedde microtephra from minerogenic lake sediments. Journal of Paleolimnology, 19, 199-206.

Veski, S., Amon, L., Heinsalu, A., Reitalu, T., Saarse, L., Stivrins, N., Vassiljev, J. 2012. Lateglacial vegetation dynamics in the eastern Baltic region between 14,500 and 11,400 cal yr BP: A complete record since the B $\varnothing$ lling (GI-1e) to the Holocene. Quaternary Science Reviews, 40, $39-53$.

Zelčs, V., Markots, A. 2004. Deglaciation history of Latvia. In: Ehlers, J., Gibbard, P.L. (eds), Quaternary glaciations - extent and chronology of glaciations, part I: Europe. Developments in Quaternary Science, 2. Elsevier, Rotterdam, pp. 225-244.

Zelčs, V., Markots, A., Nartišs, M., Saks, T. 2011: Chapter 18: Pleistocene Glaciations in Latvia. In: Ehlers, J., Gibbard, P.L., Hughes, P.D. (eds.), Quaternary glaciations - extent and chronology. A closer look. Developments in Quaternary Sciences, 15. Elsevier, pp. 221-229. 


\section{STOP 3: Late-glacial and early postglacial environmental processes and the history of the River Triečupite valley and surroundings, in the foreland of the Vidzeme Upland}

Māris Krievāns and Laimdota Kalniņa

University of Latvia

The stop is located at the River Triečupite valley $\left(25^{\circ} 20^{\prime} 3.67^{\prime \prime} \mathrm{E}, 57^{\circ} 19^{\prime} 58.46^{\prime \prime} \mathrm{N}\right)$, in the Trikāta Rise, which forms a transitional zone between the Northern Vidzeme Lowland and the Vidzeme Upland (Fig. 3.1). It gives an insight into the geological structure, morphology and formation of the deep-cut glacial meltwater drainage valley system of the rivers Triečupite, Vaive and Rauna, presenting a pattern of terraced valleys created as a result of late-glacial meltwater activity and postglacial fluvial erosion, along with an example of apron-like calcareous tufa deposition.

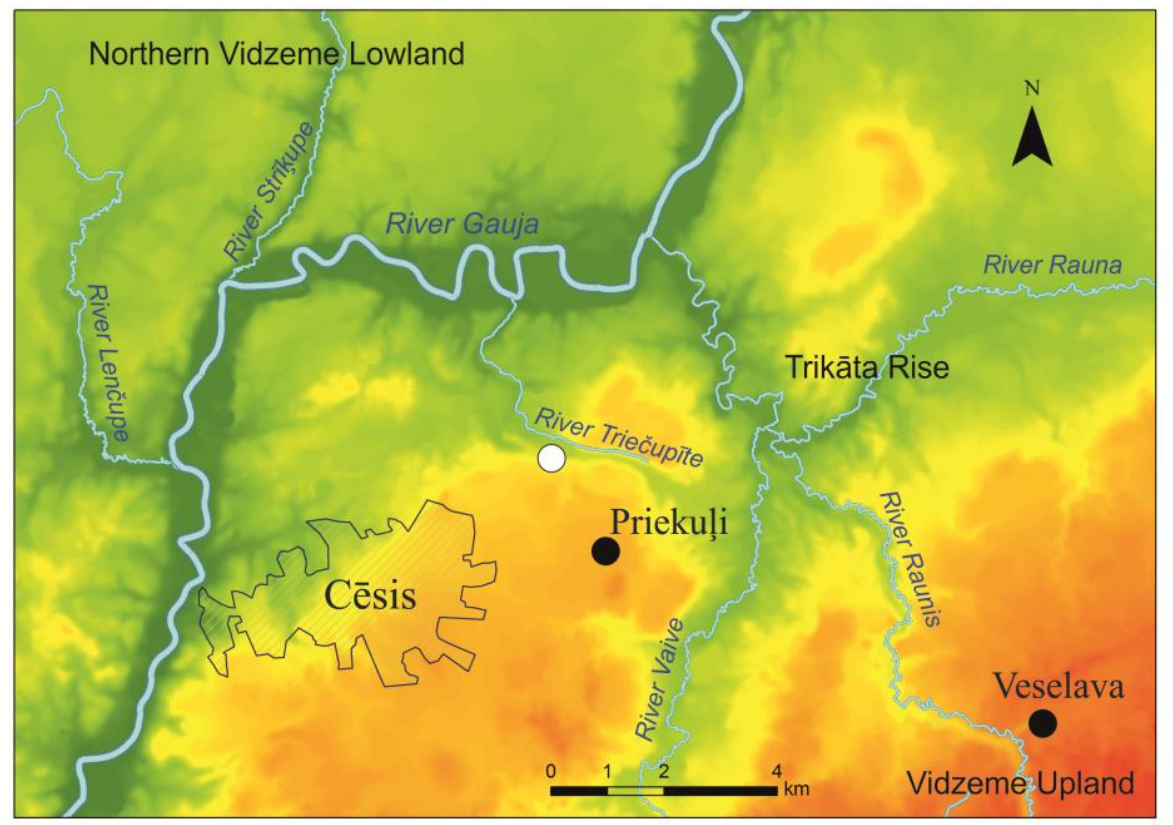

Fig. 3.1. Geographical location of the River Triečupite (Kazu grava) valley. White circle - location of Stop 3, black circles - villages.

The thickness of the Pleistocene deposits along the River Triečupite valley is less than $10 \mathrm{~m}$. They rest on Upper Devonian dolomite, underlain by Upper Devonian sandstone and clay. In places rafted blocks and subglacial till, composed mainly of the local bedrock, can be encountered. The present-day surface topography has been shaped by the Burtnieks ice lobe and meltwater activity, particularly during the initial transgression of the Late Weichselian Fennoscandian Ice Sheet and its oscillatory retreat, beginning approximately $15.2 \mathrm{ka}$ BP (Zelčs and Markots 2004; Zelčs et al. 2011).

\section{River Triečupite valley}

The Triečupite valley is about $3.6 \mathrm{~km}$ long and $0.3-0.8 \mathrm{~km}$ wide, and in the middle part its depth reaches 35-42 m. It crosses the watershed between the valleys of the rivers Vaive and Gauja. North-west of the Riga-Valka railway embankment the valley ramifies, forming a second, more elevated branch - Bušleja (Āboltiņš 1998). The River Triečupīte valley is confined to an ancient U-shaped buried valley which is incised into Middle Devonian silt, clay and sandstone, and Upper Devonian sandstone and dolomite (Bendrupe and Arharova 1981). 
The bedrock surface alongside the valley is $110 \mathrm{~m}$ a.s.l., but at the bottom of the valley it varies from $70 \mathrm{~m}$ a.s.l. in the middle course up to $50 \mathrm{~m}$ a.s.l. in the direction of both ends. In the lowest part of the Triečupite valley the bedrock is covered by Upper Pleistocene till. According to Juškevičs (2000) and Āboltiņš (1998), this indicates formation of the valley in proglacial conditions during at least part of the last Fennoscandian Ice Sheet transgression. The development of the present valley and transformation of the glacial relief in the adjoining area began with the retreat of the Burtnieks ice lobe from the marginal formations of the North Lithuanian (Linkuva) glacial phase. It can comparatively be correlated with the development of the valleys of the rivers Gauja, Rauna and Vaive as well as local meltwater basins during the Late Glacial. Alongside the slopes and within the Triečupite valley Holocene peat and alluvial sediments have accumulated (Āboltiņš 1995).

According to the field and geospatial data, the River Triečupite valley can be divided into three morphologically distinct parts - the north-western extension, the middle part and the south-eastern extension (Fig. 3.2.). In the SE extension two glaciolacustrine terraces were traceable at levels of 74 and $77 \mathrm{~m}$ a.s.l., and the highest glaciolacustrine terrace was detected at $87 \mathrm{~m}$ a.s.l. The terraces are composed of fine-grained and medium-grained sand.

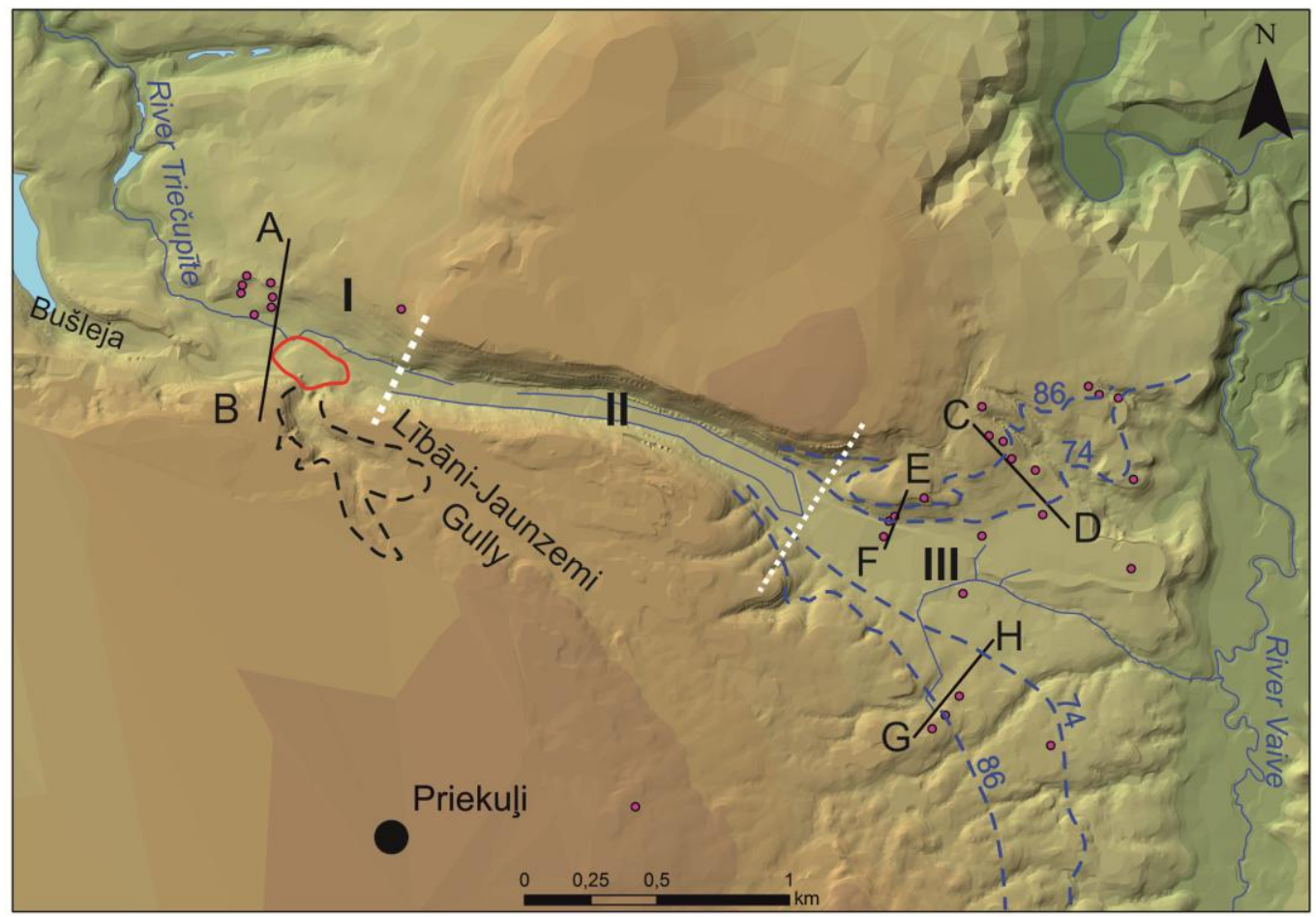

Fig. 3.2. Digital elevation model of the River Triečupite valley and surrounding area. Solid black lines show location sites of profiles; red dots indicate the location of boreholes; blue dashed lines indicate the shorelines of the Kārklini palaeobasin; the contour marked by a red solid line denotes the location of the freshwater tufa apron; white lines separate geomorphologically distinct parts of the River Triečupite valley: I - north-western extension; II - middle part; III - south-eastern extension.

The thickness of glaciolacustrine sediments varies from some tens of centimetres to a few metres. In the NW extension three terraces can be traced, at 72, 66 and $62 \mathrm{~m}$ a.s.1. (Fig. 3.3). The two highest are considered to be of erosional origin. In separate boreholes basin sediments have been detected at $65 \mathrm{~m}$ a.s.l. The middle part of the River Triečupite valley is non-terraced, with a U-shaped cross-section. Its slopes are very steep, in some places reaching the critical angle of repose. In the upper part of the valley the Upper Devonian Pl̦avinas Formation dolomite forms steep scarps. As result of suffosion of the underlying sandstone and subsequent subsidence and collapse of the cracked dolomite, a number of caves 
and sinkholes have formed. In total, eight caves occur on the right-bank slope of the river valley, as well as one cave on the left-bank slope. The best-known are Big Sikspārṇi, Medium Sikspārņi and Small Sikspārņi ('Bat') Caves. These are among the largest caves in Latvia, and are often erroneously classified as karst caves in dolomite. It is likely that the base level of the caves reflects the historic groundwater level that served as the base of suffosion.

On the basis of the spatial distribution of the fine-grained sediments, a model of the Kārkliņi palaeolake terraces has been developed (Fig. 3.2). According to this model, the palaeolake sediments and associated fluvial sedimentation occur in a much wider area than is displayed in a map by previous researchers (Zīverts and Arharova 1981), where the distribution of glacioaquatic sediments is restricted to a small area within the valley, at $75 \mathrm{~m}$ a.s.l. Between Vieksi Hill and near the Rauna-Mūrmuiža road within the valley of the River Rauna three shorelines of the Middle Rauna glacial lake can be identified, at 102, 80 and 76 m a.s.l.

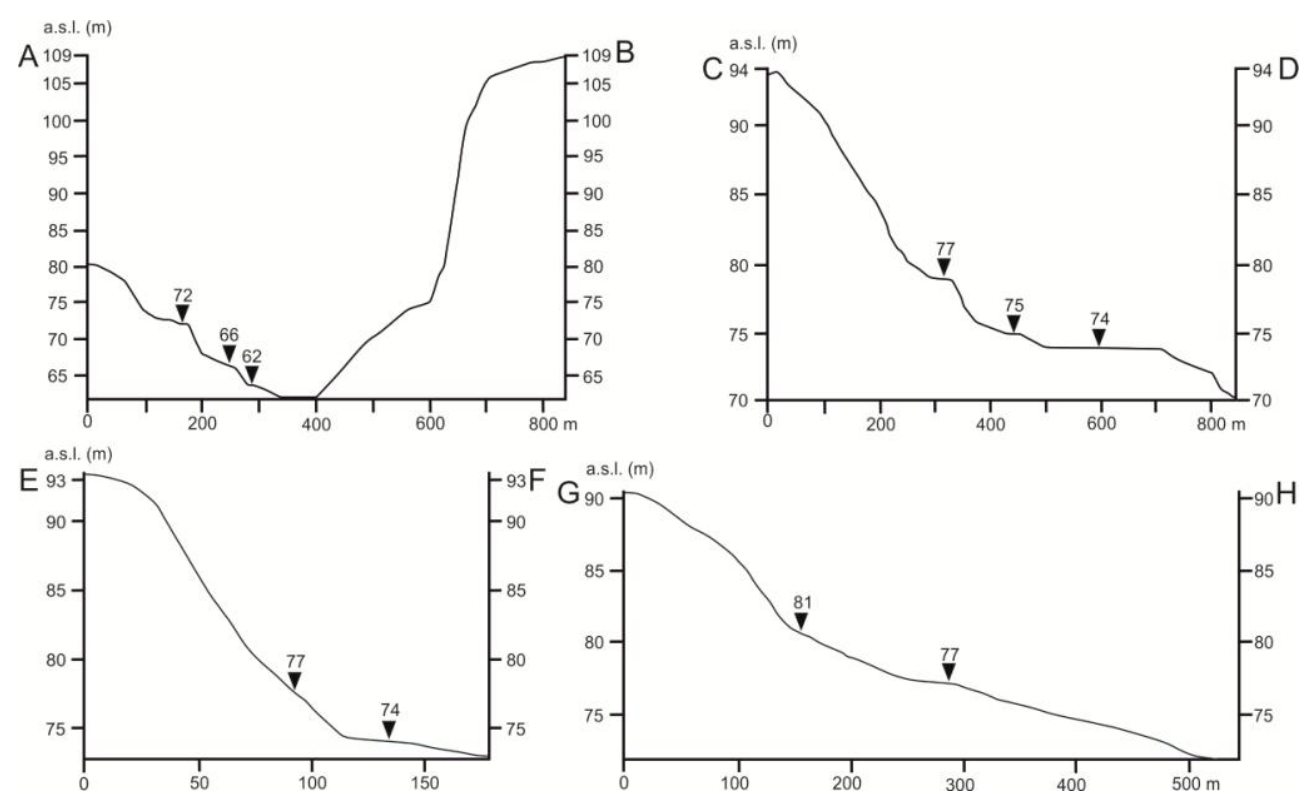

Fig. 3.3. Cross profiles of the Triečupîte valley. Triangles indicate detected terrace and shoreline levels.

Taking into account the hypsometric position of the shorelines of the Middle Rauna and Kārklini lakes, the layout of terrace-shaped forms, the surface topography and the distribution of the glacioaquatic sediments, it can be concluded that the Karrklini palaeobasin initially drained towards the west along the Bušleja into the Triečupite valley, forming a lateral meltwater drainage valley. Later on, after melting of the dead ice blocks in the depression located north of Bušleja, runoff occurred via the River Triečupite branch. The water level of the Kārkliṇi palaeobasin dropped discontinuously. Short-term stabilization phases are indicated by shorelines traceable along the southeastern extension.

\section{Palynological characteristics of the Lībāni-Jaunzemi freshwater tufa deposit}

The apron-like freshwater tufa deposit is located on the southern side of the Triečupite valley, where the Lībanni-Jaunzemi valley-like gully (Fig. 3.4), which is deeply incised into the Upper Devonian dolomite and sandstone, joins with the Triečupīte valley (Āboltiņš 1998). A freshwater tufa sequence up to 3.5-6 m high and $50 \mathrm{~m}$ wide is exposed in a quarry located at the mouth of the Lībāni-Jaunzemi valley-like gully. The total thickness of the freshwater tufa deposit (freshwater limestone, according to Āboltiņš 1998) reaches up to $12.2 \mathrm{~m}$ (Fig. 3.5).

Remains of fossil trees (branches, leaves and trunks) occur together with freshwater 
molluscs. Pollen analysis indicates that freshwater tufa precipitation started in the Boreal and lasted up to the Subatlantic (Danilāns 1957, 1973). The freshwater tufa deposit has an apronlike shape. According to Pedley (1990), freshwater tufa can be classified as a fluvial deposit precipitated by a spring. Spring water in this area has a high calcium carbonate content. Calcareous sediments were gradually deposited on the lower part of the slope. The small folds that occur in the tufa were created by sediment flows of the unconsolidated calcareous deposits (Āboltiņš 1998). However, these small-scale deformation structures are most likely responsible for the settling of the calcium carbonate on the roughened fluvial or mass-wasting erosional surface. The springs have formed a multi-level waterfall about $7 \mathrm{~m}$ high.

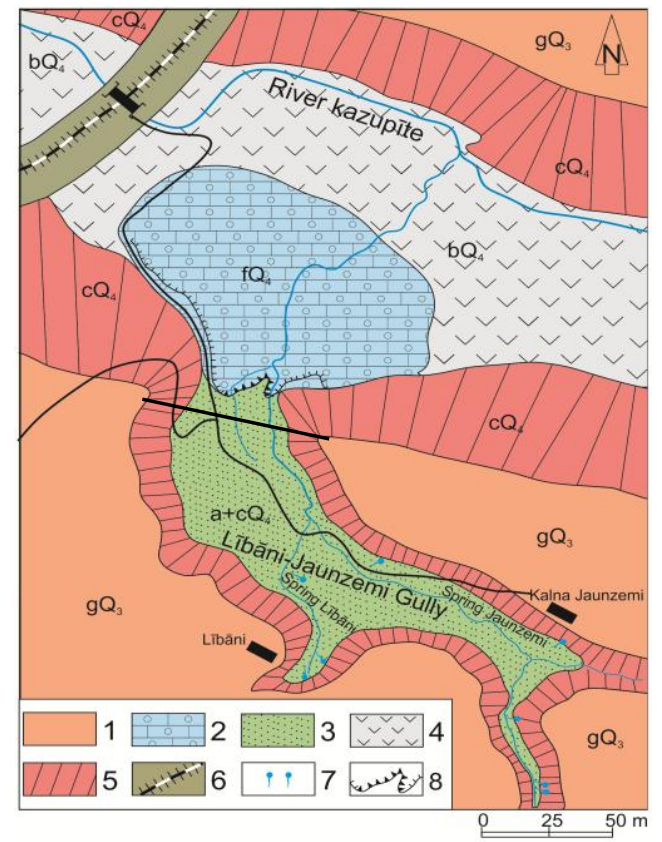

Fig. 3.4. Quaternary superficial sediments in the area of the Lībāni-Jaunzemi tufa deposit. 1 - Late Weichselian till $\left(\mathrm{gQ}_{3}\right) ; 2$ - freshwater tufa $\left(\mathrm{fQ}_{4}\right) ; 3$ - alluvial-colluvial sediments $\left(\mathrm{a}+\mathrm{cQ}_{4}\right) ; 4$ - peat $\left(\mathrm{bQ}_{4}\right) ; 5$ - colluvium $\left(\mathrm{cQ}_{4}\right) ; 6$ - railway embankment; 7 - springs; 8 - outcrop; black straight line indicates location of cross section shown in Fig. 3.5.

\section{A 7.60-m-long section of the Lībāni-Jaunzemji} tufa outcrop has been sampled for pollen analysis. These data have been used for approximate estimation of the time and environmental conditions of tufa deposition. A new pollen diagram constructed according to these data allows four local pollen assemblage zones (PAZ) to be distinguished (Fig. 3.6; Table 3.1). Zoning was done using correlations with pollen diagrams in the region and pollen data obtained from previous investigation on a 10.5-m-long sequence by A. Timšs (published in Danilāns 1957). Even though the current section is $2.9 \mathrm{~m}$ shorter, the pollen data show approximately the same characteristics of pollen spectra.

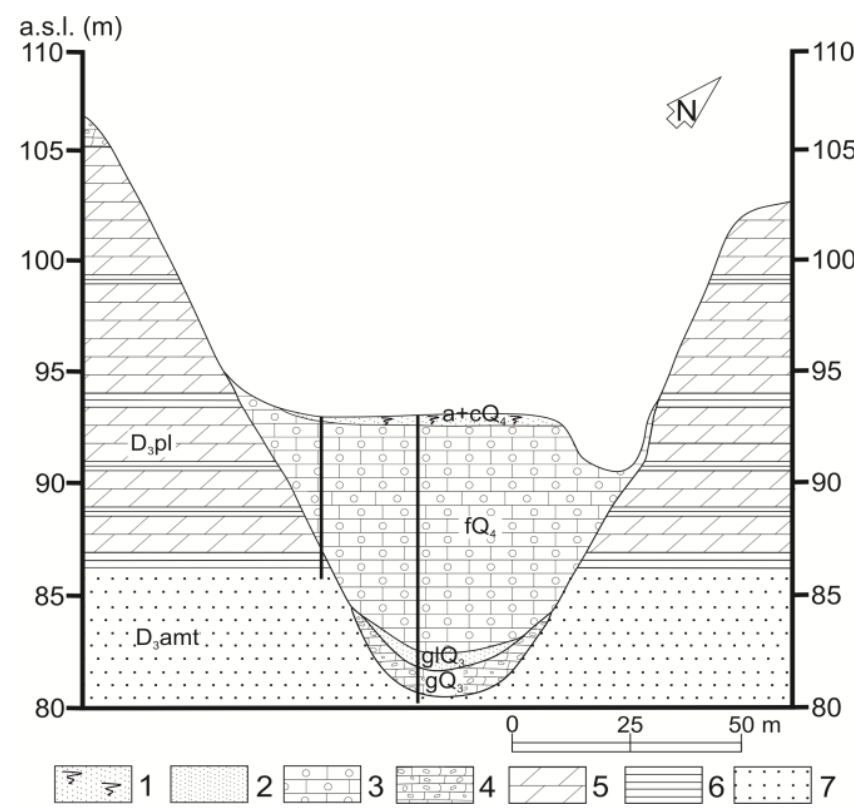

Fig. 3.5. Geological section across the LībāniJaunzemi valley-like gully (modified from Danilāns 1957).

Legend: 1 - alluvial-colluvial sediments $\left(\mathrm{a}+\mathrm{cQ}_{4}\right)$; 2 - glaciolacustrine sand $\left(\mathrm{glQ}_{3}\right) ; 3$ - freshwater tufa $\left(\mathrm{fQ}_{4}\right) ; 4$ - Late Weichselian till $\left(\mathrm{gQ}_{3}\right) ; 5$ Upper Devonian dolomite of Plavinas formation $\left(\mathrm{D}_{3} \mathrm{pl}\right) ; 6$ - Upper Devonian clay interlayers; 7 Upper Devonian sandstone of Amata formation ( $\left.\mathrm{D}_{3} \mathrm{amt}\right)$. See Fig. 3.4 for location of section.

Pollen spectra in both diagrams suggest that the most intensive freshwater tufa precipitation occurred in the Early Holocene. Sandy tufa started to be deposited at the base of both analysed sections. The proportions of tree and shrub, or arboreal (AP) and herb or non-arboreal (NAP) pollen point to a partly open mosaic landscape during the time of deposition of the freshwater tufa. No relationship has been identified between 
the pollen composition and variation in tufa types.

Table 3.1. Local pollen assemblage zones of the Lībāni-Jaunzemji tufa outcrop section.

LPAZ and chronology

LJ4

Betula-Alnus-Pinus (beginning of the

Holocene Thermal

Maximum, i.e.

beginning of the

Atlantic - AT1)

LJ3

Betula-Alnus-Pinus

(end of the Early

Holocene, i.e. 2nd part

of the Boreal - $\mathrm{BO} 2$ )

\section{LJ2 \\ Pinus}

(2nd part of the Early

Holocene, i.e. 1st part of the Boreal - BO1)

\section{LJ1 \\ Betula-Pinus \\ (1st part of the Early \\ Holocene - Preboreal)}

Description of zone

This zone is characterized by stable records of Pinus (50-55\%) and Betula (15-20\%) pollen, an increase of alder (Alnus) to $10 \%$ and hazel (Corylus) pollen up to $6 \%$, as well as the empirical maxima of pollen values of broadleaved trees, varying from 0.5 to $3 \%$. Picea percentages increase, reaching $2.8 \%$. Some increase is also characteristic for herb pollen, mainly represented by Poaceae, Cyperaceae, Ranunculaceae and Aster type.

The lower part of the laminated tufa and dense tufa in the depth interval 1.8-3.35 m contains pollen with a composition indicating a decrease of pine forest in the area, some increase in Betula, Alnus and Corylus, and the appearance of Ulmus. The occurrence of Picea and increase in ruderal plants suggest some changes in vegetation and climate. Particularly the increase in Plantago, Chenopodiaceae, Rumex and Rubiaceae indicates the possibility of human activity in the area. Spores are mainly represented by green algae Bryales and ferns Polypodiaceae.

Represented by clayey freshwater tufa in the lower part of the zone interval $(6.4-6.9 \mathrm{~m})$ and dense freshwater tufa in the upper part. Betula pollen significantly decreases and Pinus reaches its maximum (80\%) in the pollen diagram above the previous zone. The dominance of Pinus is characteristic for the first half of the Boreal in the pollen spectra of pollen diagrams for Latvia. There is still a significant presence of various herbs, suggesting that the surrounding area was not covered by dense forest. Pollen of pasture/meadow plants and also Plantago and Urtica indicates some presence of man in the area during the first half of the Boreal.

Pollen spectra indicate the dominance of Betula sect. Albae and a comparatively high amount of Pinus and herbs in the lower part of sediment sequence of the section represented by clayey and silty freshwater tufa overlying the sandy tufa at the base of the section. The herb pollen is mainly represented by Poaceae, Cyperaceae and ruderal herbs, such Artemisia and Chenopodiaceae. Total pollen composition points to a partly open landscape, covered by sparse pine-birch forest accompanied by a rich grass community. Comparison with regional pollen spectra indicates that the zone described may be correlated with the Preboreal (PB).

Many studies of freshwater tufa in Central Europe using radiocarbon datings and pollen analysis show that a peak of tufa precipitation occurred during the Atlantic and Subboreal climatic periods (5000-2500 BP) of the Holocene, when climatic conditions were warmer and wetter (Goudie et al. 1993; Banks et al. 2012). Freshwater tufa deposits in Latvia have not been dated by radiometric dating methods. The age of the freshwater tufa has been estimated approximately using pollen data. The pollen data from the new section of the Lībāni-Jaunzemi deposit allow us to conclude that the largest volume of tufa was formed before the cold event of $8200 \mathrm{cal}$ yr. BP, which is clearly expressed by a sharp peak of birch (Betula) pollen and a brief decrease in alder, hazel and broadleaved pollen (Seppä et al. 2007). This is in good agreement with studies in the Pudost massif (Nikitin et al. 2011), where accumulation of freshwater tufa (paratravertine) was determined as having occurred from $7.5 \pm 0.4$ to $6.8 \pm 0.4 \mathrm{ka}$ BP. 


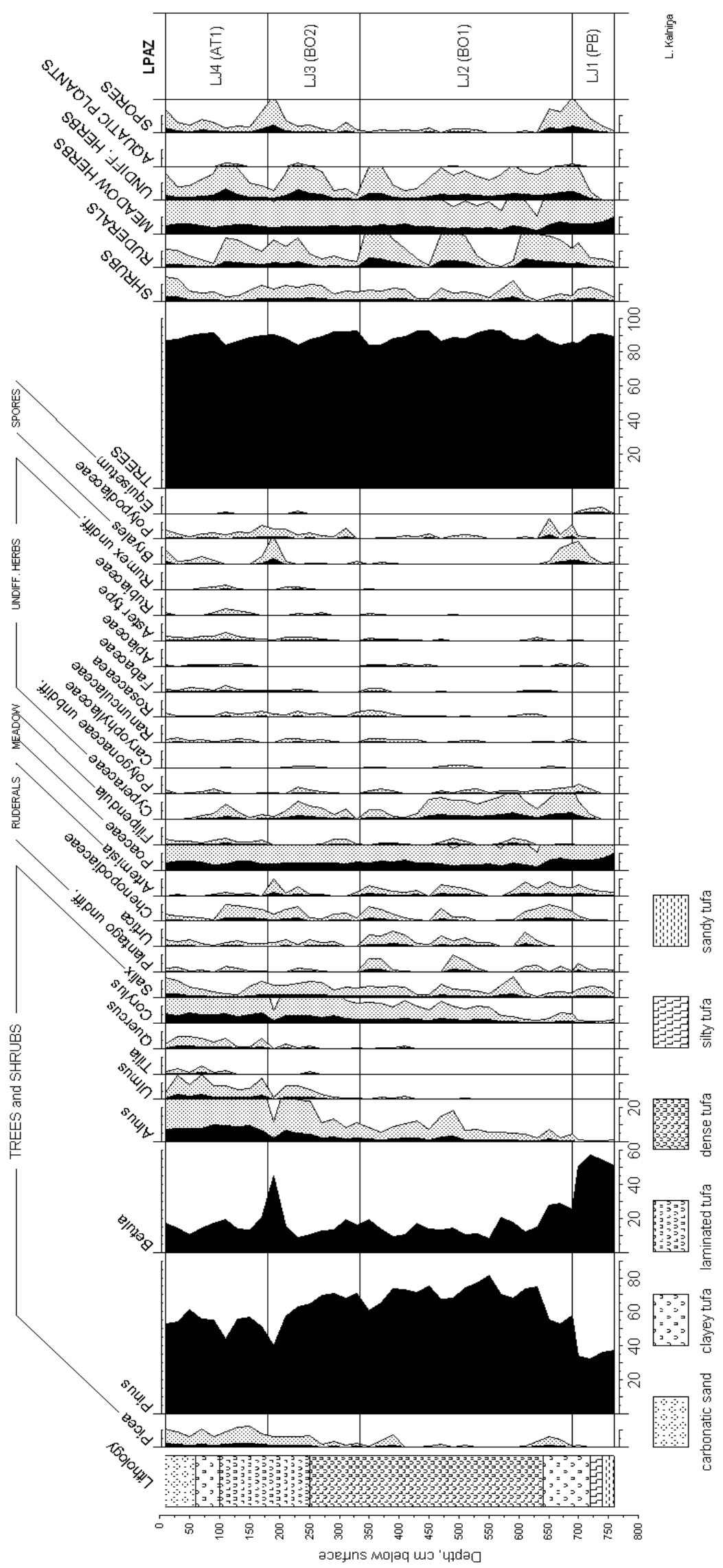

Fig. 3.6. Pollen percentage diagram for the Lībāni-Jaunzemi freshwater tufa outcrop. 
Most of the largest freshwater tufa deposits (Lake Vilgale, Pikste, Seriestade, LībāniJaunzemji) in different regions of Latvia have been studied palynologically. According to palynological data it can be concluded that freshwater tufa started to precipitate at least in the Early Holocene. In many cases the accumulation of freshwater tufa ended during the first half of the Holocene Thermal Maximum, but this also depended on the local geological conditions.

\section{References}

Āboltiņš, O. 1998. STOP 14. Holocene freshwater limestone and outcrop at Priekuļi, the vicinity of Cēsis. In Zelčs, V. (ed.), Field Symposium on glacial processes and Quaternary environment in Latvia. Excursion guide. University of Latvia Rīga, 25-31 May, 1998. University of Latvia, Rīga, pp. 79-82.

Āboltiņš, O. 1995. Kazu ieleja. Grām. Kavacis, G. (atb. red.), Latvijas daba, 2. Latvijas Enciklopēdija, Rīga, lpp. 238.

Āboltiņš, O.P. 1975. Glaciodynamic peculiarities of formation of Latvian elevations. Problems of Quaternary geology, 8, pp. 5-23 (in Russian).

Banks, V.J., Jones, P., Lowe, D.J., Lee, J., Rushton, J., Ellis, M.A. 2012. Review of tufa deposition and palaeohydrological conditions in the White Peak, Derbyshire, UK: implications for Quaternary landscape evolution. Proceedings of the Geologists' Association, 123(1), 117-129.

Bendrupe, L., Arharova, T. 1981. Geologicheskaya karta (dochetvertichnye otlozheniya) masshtaba 1:50000 [Geological map (pre-Quaternary deposits) in scale of 1:50,000]. Prilozhenije $k$ otchetu o gruppovoy geologicheskoy syomke masshtaba 1:50 000 Gaujskogo natsionalnogo parka. Upravlenije geologii, Riga, 1-3 list. Valsts ǵeologijas fonds, ID No.2095, Inv. No.09855 (In Russian).

Danilāns, I. 1957. Golotsenovyje presnovodnyje izvestkovyje otlozhenija Latvii [Holocene freshwater calcareous sediments of Latvia]. Rīga, Publishing House Academy of Science of Latvian SSR, 162 pp. (In Russian)

Danilāns, I. 1973. Chetvertichnye otlozheniya Latviji [Quaternary deposits of Latvia]. Zinātne, Rīga, 312 pp. (In Russian).

Goudie, A.S., Viles, H.A., Pentecost, A. 1993. The late-Holocene tufa decline in Europe. The Holocene, 3, $181-186$.

Juškevičs, V. 2000. Quaternary deposits. In: Āboltinš, O., Kuršs, V. (eds.), Geological Map of Latvia. Scale 1:200,000. Sheet 43-Rīga. Sheet 53-Ainaži. Explanatory Text and Maps. State Geological Survey, Rīga, pp. 10-31.

Nikitin, M.U., Medvedeva, A.A., Maksimov, F.E., Kuznetsov, V.Yu., Zherebtsov, I.E., Levchenko, S.B., Baranova, N.G. 2011. Genezis i geologicheskiy vozrast travertinopodobnykh karbonatov Pudostskogo massiva [The origin and the geological age of the travertine-like carbonates of the Pudost massif]. Journal "Society. Environment. Development" ("TERRA HUMANA"), 2011(4), 231-236 (in Russian).

Pedley, H.M. 1990. Classification and environmental models of cool freshwater tufas. Sedimentary Geology, 68, 143-154

Seppä, H., Birks, H. J. B., Giesecke, T., Hammarlund, D., Alenius, T., Antonsson, K., Bjune, A. E., Heikkilä, M., MacDonald, G. M., Ojala, A. E. K., Telford, R. J., Veski, S. 2007. Spatial structure of the $8200 \mathrm{cal}$ yr BP event in northern Europe. Climate of the Past, 3, 225-236.

Zīverts, A, Arharova, T. 1981. Geologicheskaya karta (chetvertichnye otlozheniya) masshtaba 1:50000 [Geological map (Quaternary deposits) at scale 1:50,000]. Prilozhenije $k$ otchetu o gruppovoy geologicheskoy syomke masshtaba 1:50 000 Gaujskogo natsionalnogo parka. Upravlenije geologii, Riga, 5-6 list. Valsts ğeoloğijas fonds, ID No.2095, inv. No.09855 (in Russian)

Zelčs, V., Markots, A. 2004. Deglaciation history of Latvia. In: Ehlers, J., Gibbard, P. L. (eds.), Quaternary Glaciations - Extent and Chronology. Part I: Europe. Developments in Quaternary Science, 2. Elsevier, Amsterdam, pp. 225-243.

Zelčs, V., Markots, A., Nartišs, M., Saks, T. 2011. Chapter 18: Pleistocene Glaciations in Latvia. In: Ehlers, J., Gibbard, P.L., Hughes, P.D. (eds.), Quaternary glaciations - extent and chronology. A closer look. Developments in Quaternary Science, 15. Elsevier, pp. 221-229. 


\section{STOP 4: Internal structure and genesis of the sediments underlying Terrace III of the River Gauja at Dukuḷi farmhouse and Valmiera town}

Māris Krievāns and Agnis Rečs

University of Latvia

\section{Dukuli Outcrop $\left(25^{\circ} 23^{\prime} 17^{\prime \prime} E\right.$, 57 $\left.27^{\prime} 46^{\prime \prime} N\right)$}

The outcrop is located on the scarp of Terrace III, near the Dukuli farmhouse. It stretches along the right cutbank of the River Gauja, $4.1 \mathrm{~m}$ above the lower mean river water level at this site and $33.4 \mathrm{~m}$ a.s.l. The lithological composition of the exposed sequence exhibits numerous characteristics that point towards the glaciolacustrine origin of the sediments. The thickness of these sediments (Fig. 4.1) reaches up to $4.5 \mathrm{~m}$.
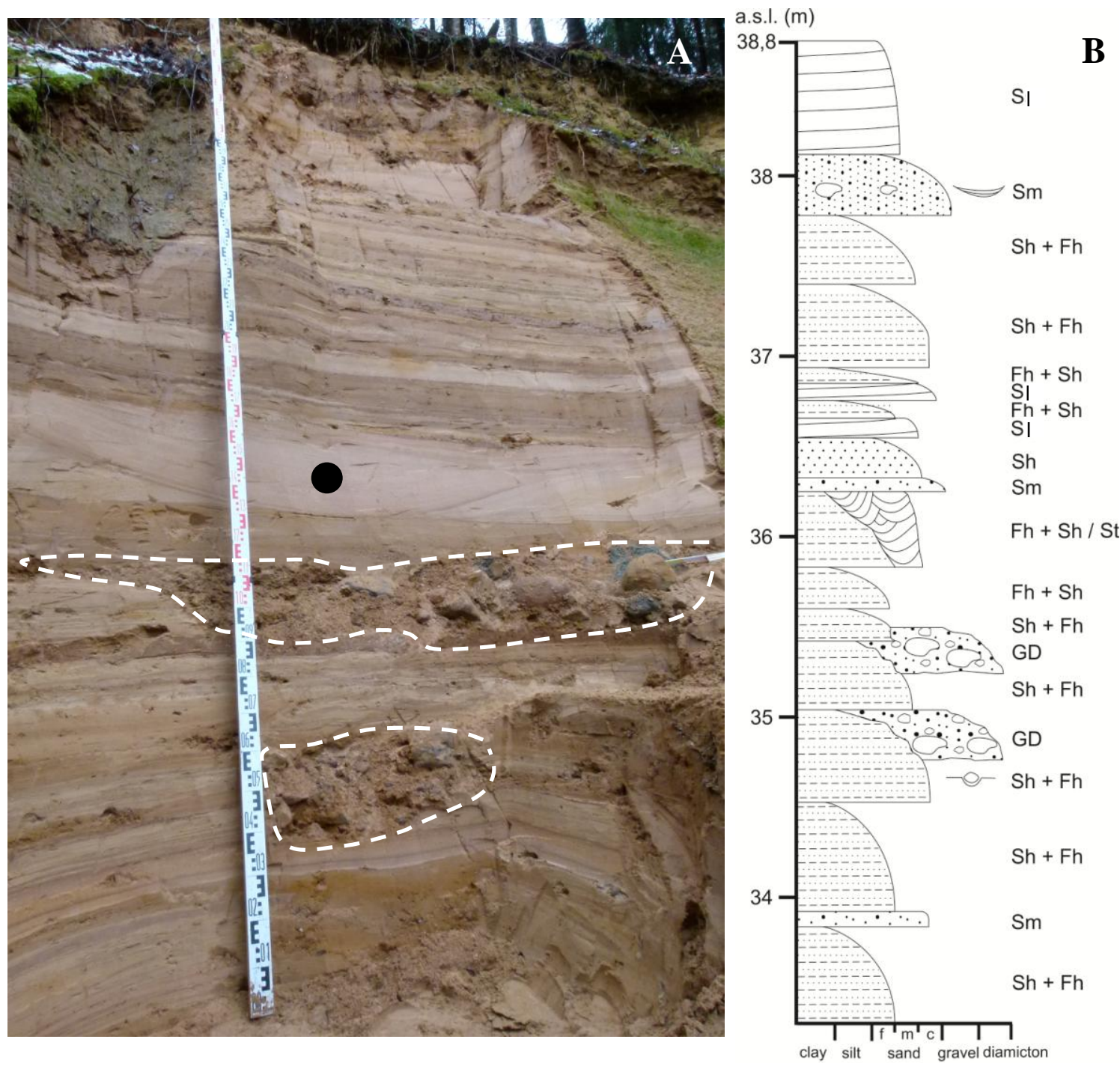

Fig. 4.1. Lithological composition (A) and sedimentary $\log (\mathrm{B})$ of the outcrop on the scarp of Terrace III of the River Gauja, near the Dukuli farmhouse. Legend: GD - diamictic gravel; Sl - low-angle cross-bedded sand; Sm massive sand; Sh - horizontally bedded sand; St - trough cross-bedded sand; Fh - parallel laminated silt. Dashed lines show contours of supraglacial diamicton lenses; black dot indicates location of the OSL sampling site.

The lower part of the sequence consists of fine-grained sand interbedded with silt, with an admixture of clay. In the lower part of the outcrop there are a couple of supraglacial till lenses cased in stratified material (Fig. 4.1). The topmost part of the section consists of silt 
and fine-grained sand with weakly expressed ripple cross-laminae (Fig. 4.1).

The lithological composition, textures and facies analysis of the sediment units provide evidence that they accumulated in a basin, probably in a glaciolacustrine environment, rather than being of alluvial origin, as interpreted in previous studies (Ābolkalns et al. 1960). Still uncertain is the question of the genesis of Terrace III of the River Gauja. In previous studies (Ābolkalns et al. 1960; Āboltinss 1969, 1971), both of the highest terraces of the lower complex (Terrace III and Terrace II) were related to levels of the stage Bgl II and phase Bgl III $_{\mathrm{b}}$ of the Baltic Ice Lake (Grīnbergs 1957; Āboltinš 1971). Next to the Liěci Sanatorium, in Terrace III of the River Gauja, below floodplain alluvium, macroscopic plant remains were found. Accumulation of these plant remains occurred as early as 10,535 \pm 0.25 (Ri-33) and $10,282 \pm 0.25$ (Ri33A) ${ }^{14} \mathrm{C}$ years BP (Stelle et al. 1975a, b). The sediment depositional environment was interpreted as an oxbow lake and floodplain members (Ābolkalns et al. 1960; Āboltiñs 1971). The latest studies of the outcrop, exposing the internal structure of the riser of Terrace III on the right bank of the river north of the Dukuli farmhouse, testify to sediment deposition in a palaeobasin in contact with dead ice. Such an interpretation is also supported by evidence of supraglacial diamicton lenses in the lower part of the outcropping section (Fig. 4.1). Only the upper part of the outcrop (Fig. 4.2) indicates an alluvial or alluviallacustrine sediment accumulation environment, which came about as a result of drainage from a meltwater basin.
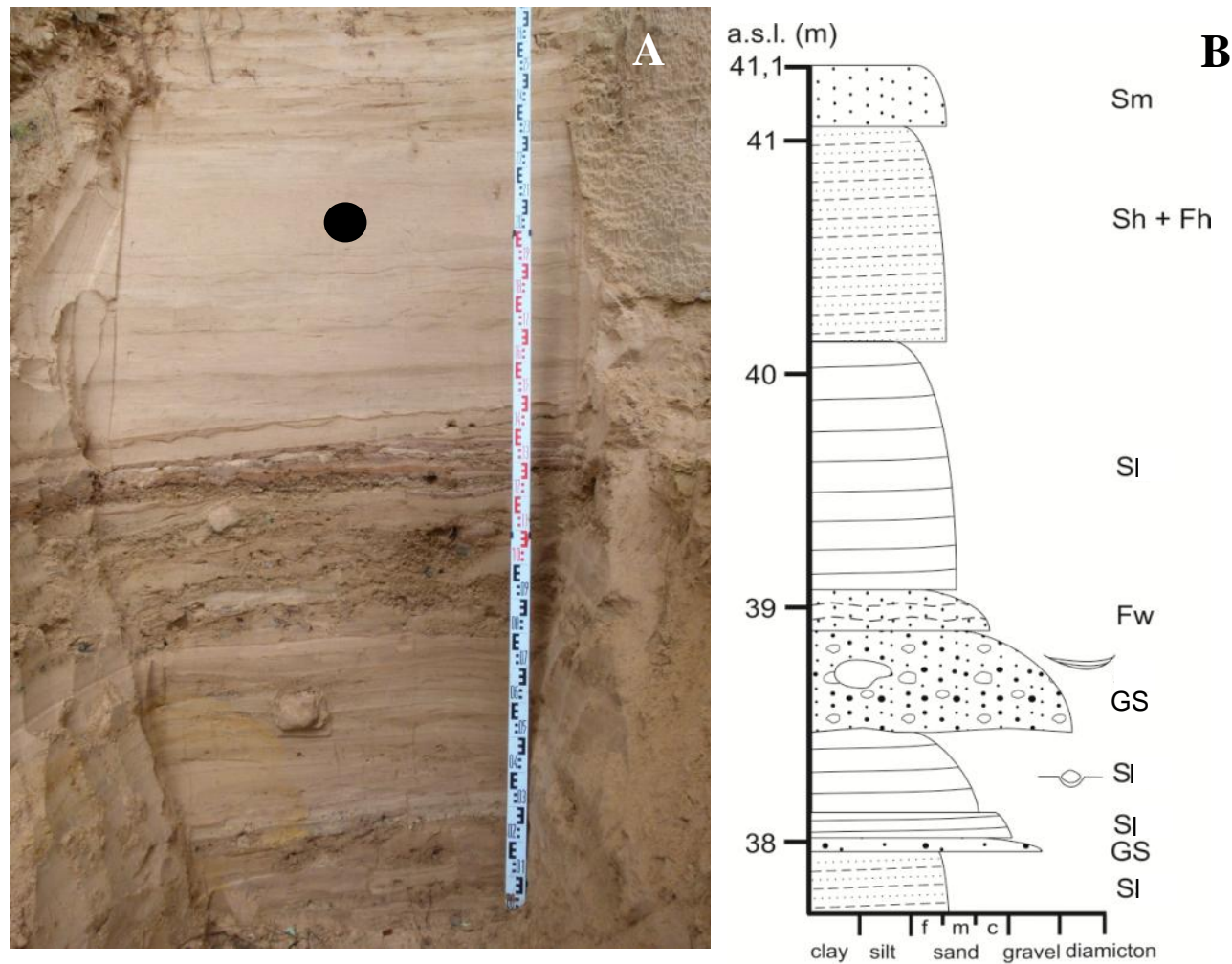

Fig. 4.2. Lithological composition (A) and sedimentary $\log (\mathrm{B})$ of the upper part of the section at the Dukuli farmhouse. Legend: GS - sandy gravel; Sm - massive sand; Sh - horizontally bedded sand; Sl - low-angle crossbedded sand; Fh - parallel laminated silt; Fw - wavy laminated silt. Black dot indicates the position where the OSL dating sample was taken.

After palaeobasin leaking, downcutting and erosion terrace formation started in the River Gauja valley. Therefore, this sedimentary sequence has been distinguished from the formation of Terrace III. According to geological and geomorphological evidence (Āboltinšs 1971), downcutting occurred at this time and the riverbed gradually narrowed. 


\section{Steep Banks Outcrop $\left(25^{\circ} 26^{\prime} 41^{\prime \prime} E, 57^{\circ} 32^{\prime} 45^{\prime \prime} N\right)$}

The outcropping scarps known as the Steep Banks ('Stāvie krasti') constitute one of the best-known geological monuments of Latvia. These scarps open out along the right cutbank of the River Gauja, $1 \mathrm{~km}$ downstream of the embouchure of the River Abuls, and almost $250 \mathrm{~m}$ downstream of the Dalini farmhouse, in the territory of Valmiera town. Due to erosion by the River Gauja in springs the Steep Banks consist of a 280-m-long series of fresh exposures (Fig. 4.2). The height of the scarps varies between $10 \mathrm{~m}$ and $15 \mathrm{~m}$, and the width of some sections can be up to $80 \mathrm{~m}$. Detailed study of the sediments forming the Steep Banks was carried out in the cutbank of the river meander in a $13.3 \mathrm{~m}$ high outcrop (Fig. 4.3), the upper head of which is located $43.1 \mathrm{~m}$ a.s.l. The lowermost part of the outcrop is occasionally covered by talus a few metres (up to $4 \mathrm{~m}$ ) thick. The Steep Banks have been known for long time and are considered as providing one of the most complete records of Terrace III of the River Gauja (Āboltiņš 1969, 1971).
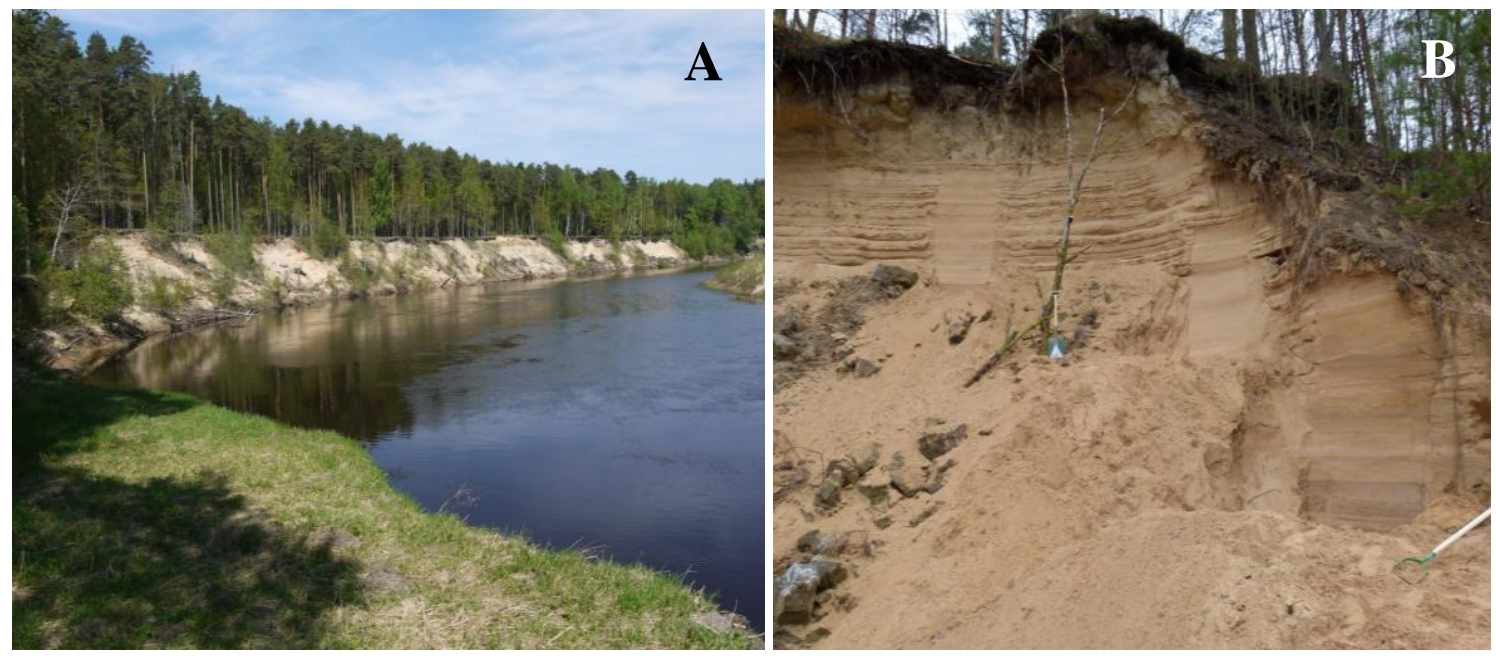

Fig. 4.3. View of the partly outcropping scarps of the Steep Banks (A) and a portion of the outcrop studied in detail (B).

Based on the results of composition, structure and rhythmic changes of the lithofacies, the upper $7.25 \mathrm{~m}$ of the scarp can be divided into 44 sedimentation rhythms. According to their characteristics, these rhythms can be grouped into four facies associations (Fig 4.4).

In the part of the section under consideration the typical sedimentation rhythm starts with partial or thorough washing-away of the upper part of the underlying rhythm. Thus, the lower part of the rhythm is formed by horizontally layered fine-grained clay and silty sand with a silt admixture. The horizontal structures possibly do not indicate slow water flow, but actually provide evidence of relatively rapid flow, which forms in the upper flow regime of a watercourse. In the upper flow regime resistance to flow is small and sediment transport is high. Planar lamination forms when the flow is strong enough that the beds flatten out. The momentum of the transported grains and fluid is high enough that they tend to move horizontally, eroding any irregularities in the bed. In the rhythms the granulometric composition decreases upwards and current ripples appear; at the end of the rhythm the ripples are covered with silt or a silty clay lamina. In the middle part of the section water current climbing ripples turn into sinusoidal ripples, which are capped by silty clay lamina a few millimetres thick. The next rhythm starts with partial washing-away of the previous layer and ripples. According to the lithological composition in the upper $2.05 \mathrm{~m}$ of the outcrop two associations of facies can be distinguished, overlain by a massive sand layer. 
a.s.l. (m)

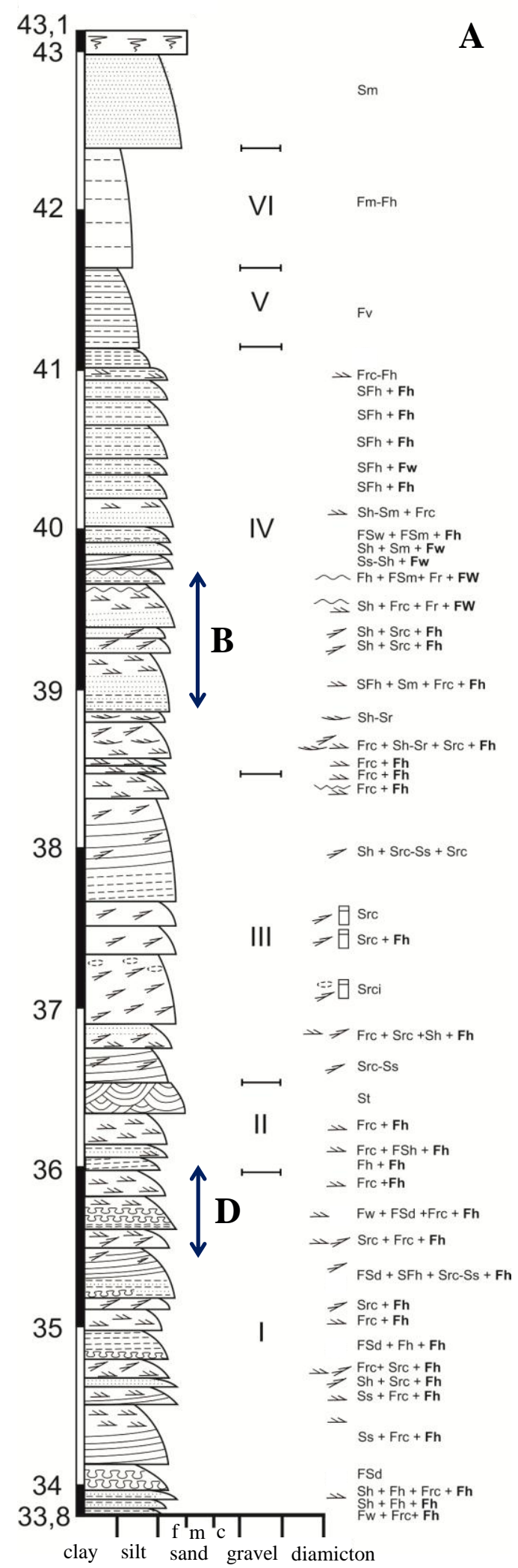

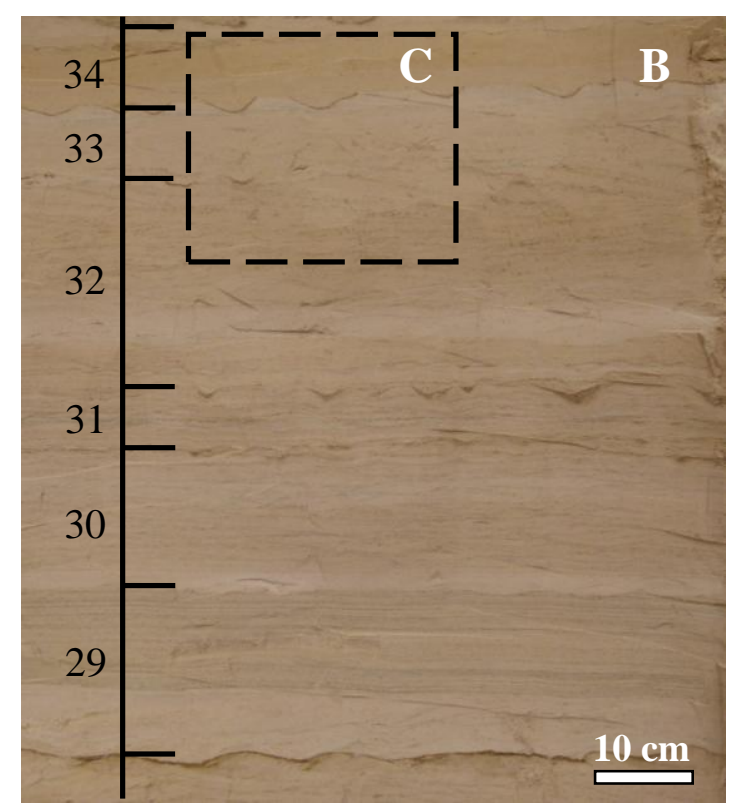
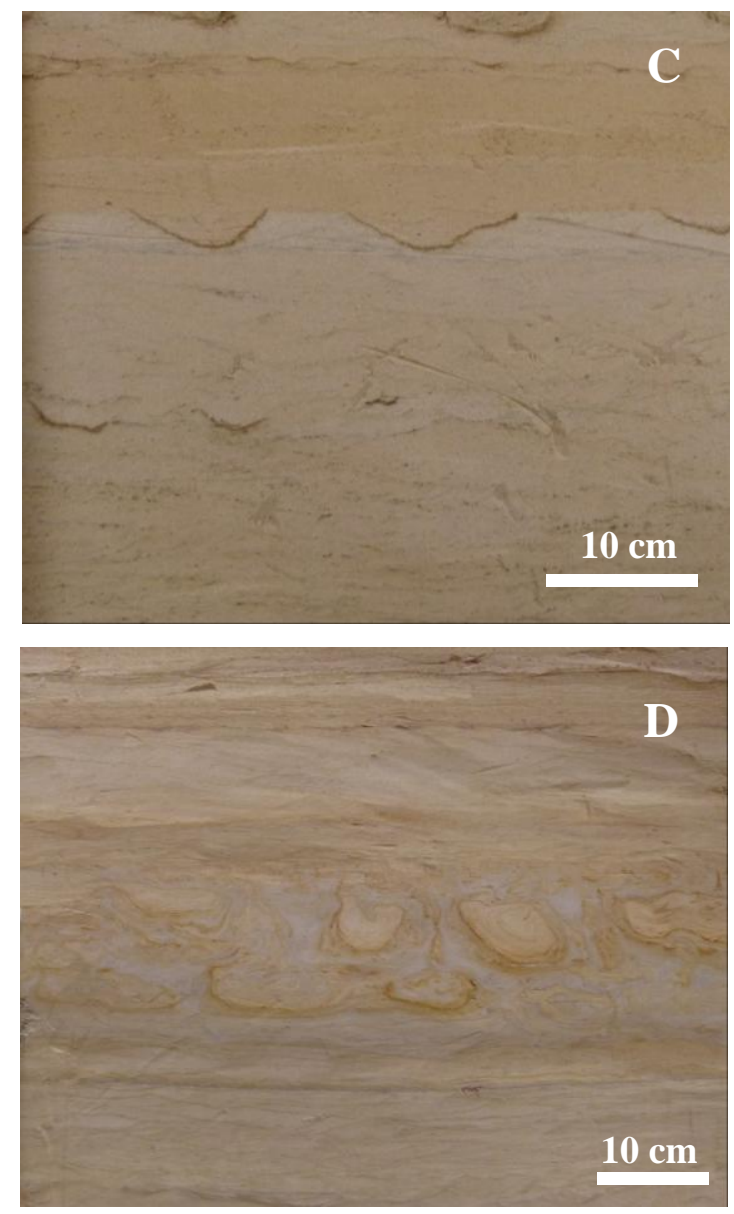

Fig. 4.4. A. Sedimentary log of the Steep Banks outcrop on Terrace III along the right bank of the River Gauja. Legend: Sm - massive sand; Sh - horizontally bedded sand; St - trough cross-bedded sand; Ss - scour-fill sand; Src - climbing-ripple cross-laminated sand; $\mathrm{Sr}$ - ripple cross-laminated sand; SFh - horizontally bedded silty sand; SFrc - ripple cross-laminated sand - ripple cross-laminated silt; FSm - massive sandy silt; FSw - wavy sandy silt; FSm - massive sandy silt; FSd - deformed sandy silt; Fm - massive silt; Fh - parallel laminated silt; FV - silt and clay in varves; Frc - climbing-ripple cross-laminated silt; Fw - wavy laminated silt; I, II, III, IV, V, VI - facies associations; B. lithofacies combined in sedimentation rhythms (numbers show sequence of rhythm); C. truncated upper part of rhythm; D. water escape structures in sandy silt. 
The first facies association (Fig 4.4) was distinguished at $4 \mathrm{~m}$ to $6.18 \mathrm{~m}$ above the present lower mean river water level. It consists of 15 sedimentary rhythms which vary from other facies in having a finer granulometric composition, as well as four layers with wellmarked dehydration structures. The next facies association, which is distinguished at $6.18 \mathrm{~m}$ to $6.95 \mathrm{~m}$ above the present river level, contains four fine sand rhythms. In comparison to the previous one, better expressed in this facies association is horizontally bedded sand, in addition to which planar cross-bedded sand also present.

The third facies association can be distinguished between $6.95 \mathrm{~m}$ and $8.69 \mathrm{~m}$ above the lower mean River Gauja level. It is consists of 7 rhythms. These are characterised by a smooth transition from the unformed ripples to clearly expressed current ripples. The horizontal layers formed in the upper flow regime occur only in some rhythms. In addition, a lamina of silty clay a few millimetres thick which concludes the rhythm has been partially washed away. The next facies association can be distinguished between $8.69 \mathrm{~m}$ and $11.4 \mathrm{~m}$ above the present lower mean river level. It consists of 19 sedimentary rhythms. The lower part of this section consists of clearly expressed sedimentation rhythms with horizontal bedded sand, current ripples and a final silty clay layer. The sinusoidal ripples disappear at the base of this facies. The fifth facies association, encountered at a height of $11.4 \mathrm{~m}$ to $11.87 \mathrm{~m}$ above the lower mean water level, consists of an alternation of 1-2 $\mathrm{cm}$ thick silt lamina with a small admixture of silty sand and $0.5-1 \mathrm{~cm}$ thick darker silty clay lamina.

Another facies association (Fig 4.4) can be identified between $11.87 \mathrm{~m}$ and $12.63 \mathrm{~m}$ above the present lower mean river level, distinguished by brownish grey clay with a silt admixture. In this layer darker horizontal laminae a few millimetres thick are visible. The section ends with a $0.7 \mathrm{~m}$ thick layer of massive fine sand with an admixture of silt.

The basic structure of the sequence indicates seasonally fluctuating water flow regimes and a transgressive sedimentation system which probably indicates base level rise. This is evidenced by nearly homogeneous sediment size composition, texture and well resolved sedimentary cycles, the above-described structural characteristics indicating seasonal changes in the strength of the water flow.

\section{References}

Ābolkalns, J., Majore, M., Stelle, V. 1960. Driasa floras atliekas Gaujas ielejas trešās virspalu terases nogulumos. Proceedings of the Academy of the Latvian SSR, 8(157), 99-107.

Āboltiňš, O. 1969. The types of alluvium of the Holocene terraces of the Gauja river valley. In: Danilāns, I. (ed.), Questions of Quaternary geology, IV. Publishing House „Zinatne”, Rīga, pp. 121-140 (In Russian, with English summary.).

Āboltiņš, O. 1971. Razvitije dolini reki Gauya [Development of the River Gauja valley]. Zinātne, Rīga, 105 pp. (In Russian)

Grīnbergs, E. 1957. Pozdnelednikovaja i poslelednikovaja istorija poberezja Latvijskoj SSR [Late-glacial and postglacial history of the coastal plains of Latvian SSR]. Publishing House of Academy of Sciences of Latvian SSR, Rīga, 122 pp. (In Russian)

Stelle, V., Savvaitov, A.S., Veksler, V.S. 1975a. Datirovaniye pleistotsenovykh otlozheniy na territorii Latvii [Dating of Pleistocene deposits in the territory of Latvia]. In: Savvaitov, A.S., Veksler, V.S. (eds), Opyt $i$ metodika izotopno-geokhimicheskikh issledovaniy v Pribaltike i Belorussii. VNIIMORGEO, Riga, pp. 8081 (in Russian).

Stelle, V., Veksler, V.S., Āboltiņš O. 1975b. Radiouglerodnoye datirovaniye allyuvialnykh otlozheniy srednego techeniya reki Gauyi [Radiocarbon dating of the alluvial deposits of the Middle course of the River Gauya]. In: Savvaitov, A.S., Veksler, V.S. (eds), Opyt i metodika izotopno-geokhimicheskikh issledovaniy v Pribaltike i Belorussi. VNIIMORGEO, Riga, p. 87-88 (in Russian). 


\title{
STOP 5: Veselava end moraine, north-western Vidzeme Upland
}

\author{
Vitālijs Zelčs, Māris Krievāns and Ivars Strautnieks
}

University of Latvia

The retreat of the Late Weichselian Fennoscandian ice sheet over the north-western part of the Vidzeme Upland is marked by three major ice-marginal zones (in order of decreasing age and hypsometric position: Kaldabruņa, Gulbene and Linkuva) (Meirons et al. 1976; Zelčs et al. 2011). Traditionally, these ice-marginal zones have tentatively been correlated with the South Lithuanian, Middle Lithuanian and North Lithuanian ice-marginal zones in Lithuania, respectively (Āboltiņš et al. 1972; Āboltiņš et al. 1975; Meirons et al. 1976; Zelčs and Markots 2004), but new OSL dates from the Middle Gauja Lowland (Nartišs and Zelčs 2011) shed doubt on the previous interregional correlation (ibid.) of the Linkuva ice-marginal formations with the Haanja zone in Estonia.

The Veselava end moraine is an almost $8 \mathrm{~km}$ long and 750-1200 m wide ridge in a chain of Linkuva ice-marginal features which extend discontinuously over the outer ice contact slope of the Vidzeme Upland (Fig. 5.1). On the highest part between the Silenieki and Lỉbieši gravel pits (see Fig. 5.2 for location) its maximum elevation varies from 160 to $170.6 \mathrm{~m}$. The topmost part of the ridge has a slightly uneven recent surface topography complicated by superimposed small hillocks and elongated ridges, pitted in places. The end moraine rises above the upglacierlocated till plain by up to $30 \mathrm{~m}$, about $60 \mathrm{~m}$ above the Raunis palaeolake plain and $10-20 \mathrm{~m}$ above the bottom of the ice-marginal drainage valley (Fig. 5.2). The end moraine has an asymmetrical cross-profile, with a shorter and steeper downglacier slope.
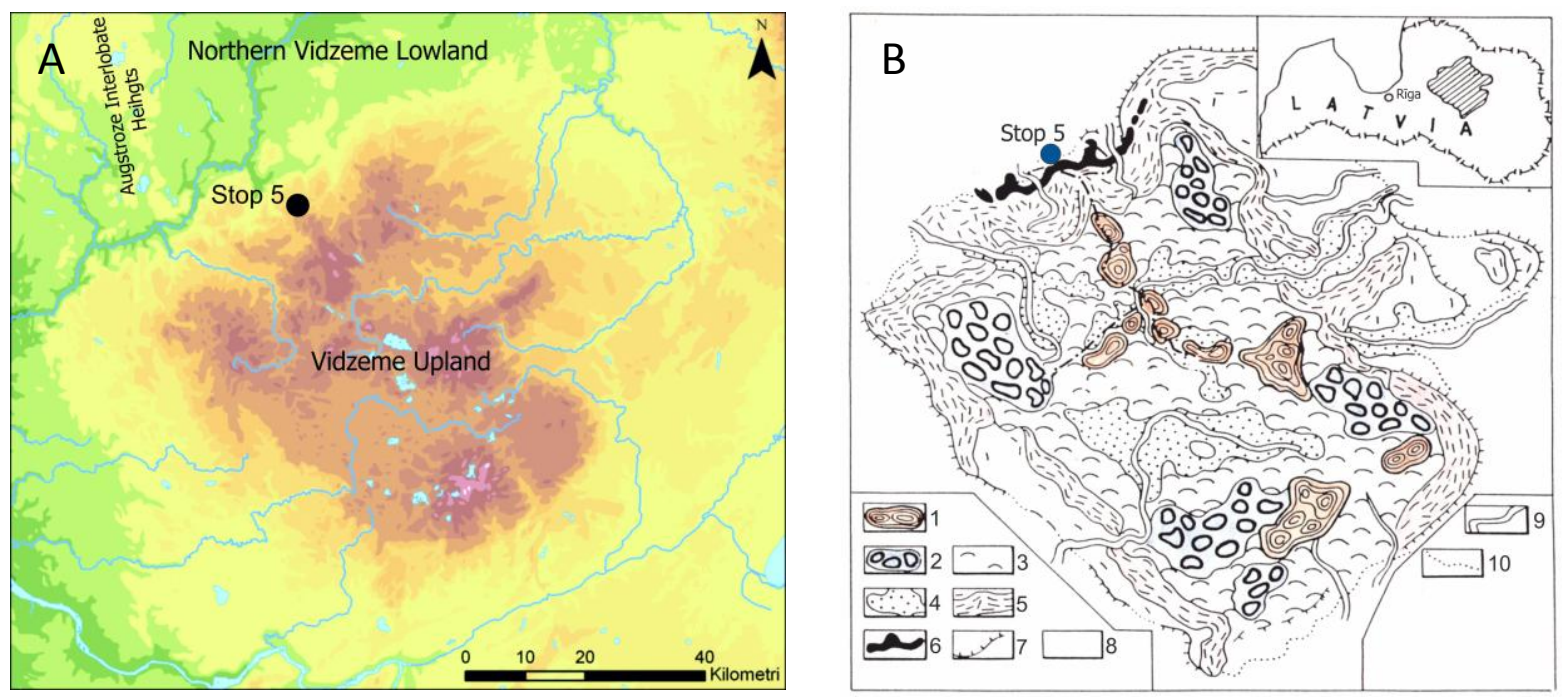

Fig. 5.1. Location of the Veselava end moraine and the stop site. A. Digital elevation model of the Vidzeme Upland and surrounding terrain. B. Geomorphological sketch of the Vidzeme Upland (modified after Āboltinš 1995). Legend: 1 - composite interlobate hilly massifs; 2 - areas of plateau-like hills; 3 - various types of hummocks (with prevalence of morainic hummocks); 4 - largest glacial depressions; 5 - ice-marginal formations of the outer zone; 6 - end moraines and ramparts of ice-tongue lateral coalescence in the outer zone; 7 - marginal slopes; 8 - rolling plains in adjoining glacial lowlands; 9 - largest river valleys; 10 - boundary of the Vidzeme Upland.

The hypsometric position of the bedrock surface ranges from $50-80 \mathrm{~m}$ to $100-110 \mathrm{~m}$ a.s.l. The end moraine is located next to the area of the lithological boundary between Devonian terrigenous and carbonate sedimentary rocks. This boundary is morphologically expressed as a dolomite escarpment up to $40 \mathrm{~m}$ high covered by less than $12 \mathrm{~m}$ thickness of Quaternary 
sediments. Weakly cemented sandstone or soft silt and clay is found underlying small, low bedrock depressions, whose strike coincides with the ice flow direction or buried valleys which tend follow the edge of the dolomite escarpment. These small bedrock depressions have a tongue-like shape and are quite well reflected in the modern topography (Fig. 5.2, note River Raunis depression). Presumably, due to the faster ice flow in the centre of the bedrock depression in comparison to ice flow alongside the lateral slopes, the Veselava end moraine is slightly curved downglacier. Dolomite forms the most elevated compartments of the subQuaternary surface. In addition, the dolomite plates gently dip against the ice movement direction with a gradient of about $9 \mathrm{~m}$ per $1000 \mathrm{~m}$. Evidently, this has stimulated glacier rafting and assimilation of local dolomitic bedrock material. The Veselava end moraine rests on dolomite, at a minimum distance of only $2-3 \mathrm{~km}$ downglacier from the escarpment.

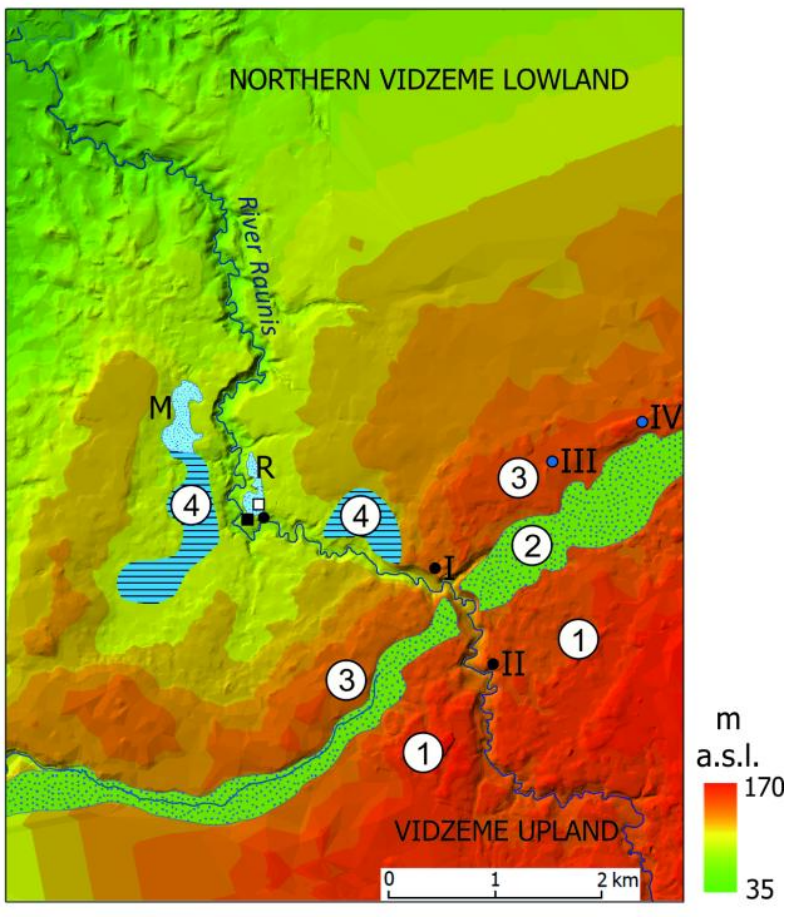

Fig. 5.2. Digital elevation model of the Veselava end moraine and adjoining area. Legend:

1 - Gulbene ice-marginal zone; 2 - ice-marginal drainage channel; 3 - Veselava end moraine of Linkuva phase ice-marginal zone; 4 - occurrence of glaciolacustrine deposition at levels of 125-140 m a.s.l. Late-glacial and Early Holocene palaeolakes with the highest level $110 \mathrm{~m}$ a.s.l: $\mathrm{R}$ - Raunis; $\mathrm{M}$ Mīlǐši. Figures I and II denote location of sections studied by Āboltinšs (1972, 1975), III and IV location of Silenieki and Lībieši gravel pits, respectively.

The thickness of Pleistocene deposits in the Veselava end moraine is $40 \mathrm{~m}$ on average. In general they thin out in the proximal direction. The buried bedrock valley, which coincides with an ice-marginal drainage channel (Fig. 5.2), is filled with an almost 100-m-thick sequence mainly composed of till (tentatively assigned by Meirons and Straume (1979) to Middle and Upper Pleistocene glacials), with interlayered thin glacioaquatic sediments. Between the two upper till units warmer period sediments were found in a coring section placed distally from the end moraine. Similar silty sand sediments with silt and clay intercalations containing disseminated organics and macroscopic plant remains were encountered by Āboltiňš (pers. comm.) in the lower part of both sections (see Fig. 5.2: I and II for location), studied at the beginning of the 1970s (Āboltiņš 1972, 1975).

Āboltinss $(1972,1975,1989)$ emphasized the complicated internal structure of the exposed deposits, noting the abundance of glaciotectonic deformation in bedded and laminated gravel, sand, silt, clay and basal till. He (ibid.) divided the Veselava end moraine cross-section into two different parts: the lower portion, with intensive glaciotectonic folding, and the topmost part, where these folded strata are overlain by up to four imbricate thrust scales of till with assimilation contacts at the base of some till sheets. In addition, the till overthrusted scales are capped by thin $(2-3 \mathrm{~m})$ sandy gravel with sandwiched silt and silty sand interlayers. Glaciokarst phenomena are also common in the covering strata, giving rise to some topographic undulations.

The Silenieki and Lìbieši gravel pits are located on the highest part of the end moraine ridge and have a more lateral position in comparison to the sections studied by Āboltinšs (Fig. 5.2). 


\section{Silenieki gravel pit section}

The section is located in the topmost part of the end moraine $\left(25^{\circ} 29^{\prime} 35^{\prime \prime} \mathrm{E}, 57^{\circ} 17^{\prime} 58^{\prime \prime} \mathrm{N}\right)$. The surface of the end moraine abounds in erratic boulders. The exposed sequence is up to 4 $\mathrm{m}$ thick. In its upper part this section, transverse to the moraine ridge crest, consists of pebbles with cobbles interlayered by massive diamicton (Fig. 5.3). The diamicton macrofabric is relatively strong, but dispersed. The macrofabric maximum strikes at an acute angle to the moraine ridge crest. Strong fabric is common in the direction of shear (Bennett and Glasser 2009). Both shear zones in the section can be interpreted as proglacial thrusting. The material is poorly sorted, coarsening upward, and contains a lot of local dolomite clasts. The dolomite clasts are angular, in places striated and faceted. The coarse clastic part of the section is underlain by silt of varying thickness. The lower contact of the silt apparently originates from erosion of the underlying fine-grained sand interlayered with silt. On the right hand side of the section both lithological units are folded concordantly with one another, probably because of mass flow.

The OSL age of burial of the sand deposited in the lower part of the Silenieki section is $59 \pm 10 \mathrm{ka}$. An OSL date of $33.6 \pm 6.4 \mathrm{ka}$ of has been obtained in the northern part of the Burtnieks drumlin field, in the vicinity of Rüjiena town. This seems to indicate sand deposition during the Middle Weichselian interstadial.

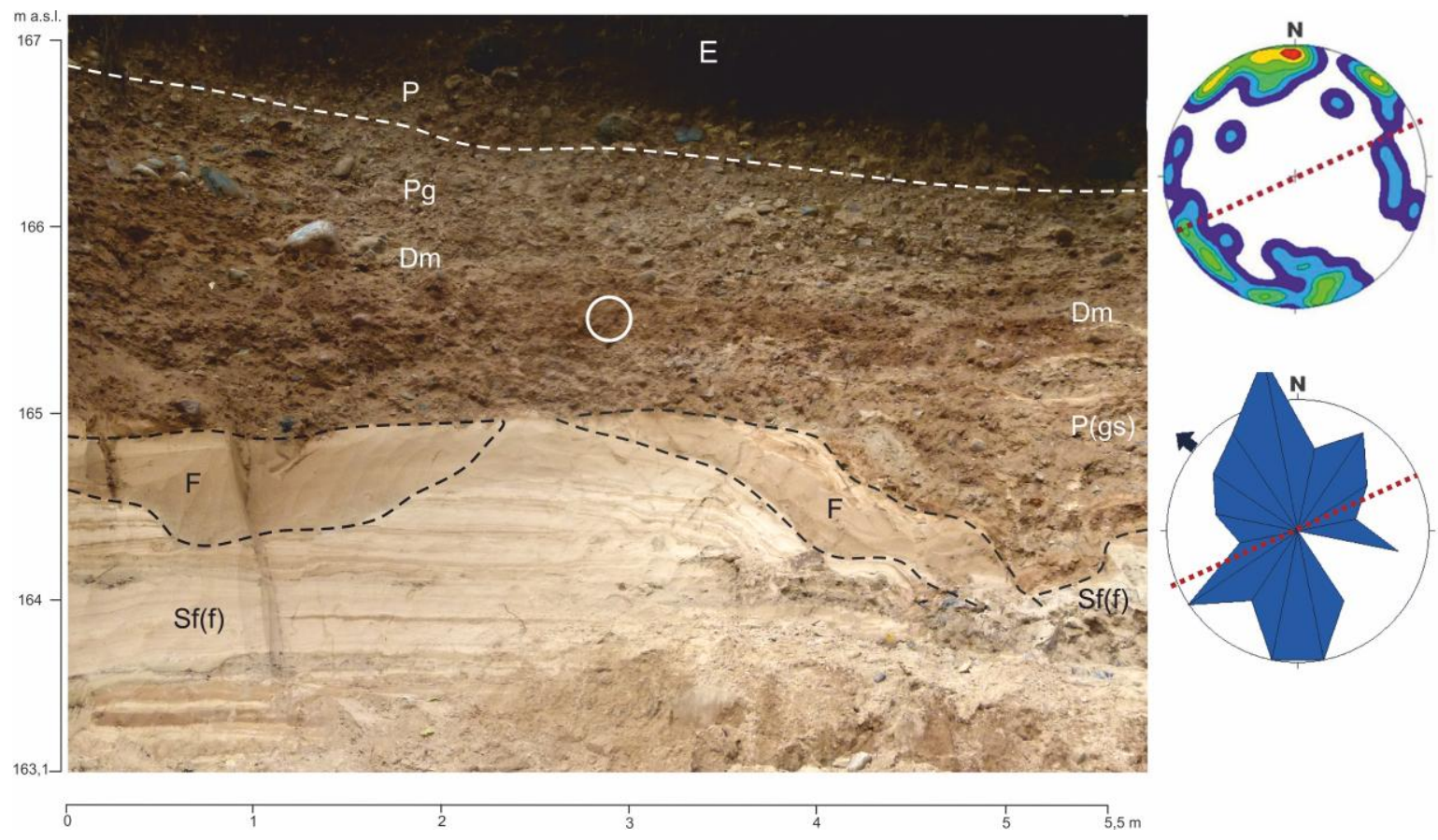

Fig. 5.3. Internal structure of the topmost part of the Veselava end moraine in the Silenieki gravel pit and clast fabric countour and rose diagrams in the lower diamicton interlayer.

Legend: F - silt, Dm - diamicton massive, P - pebbles with occasional cobbles, Pg - pebbles and gravel; P(gs) pebbles and gravel mixture with sand matrix, $\mathrm{Sf}(\mathrm{f})$ - fine grained sand interlayered by silt, $\mathrm{F}$ - fines. Large circle denotes macrofabric measurement site, red dotted line shows strike of the end moraine ridge crest.

Three-dimensional diagram of macrofabric orientation is on the lower hemisphere and in equal area projection. Based on 50 macrofabric measurements. Contoured at $0-1-2 \ldots 7$ percent areas.

\section{Lībieši gravel pit section}

This section is located about $1.5 \mathrm{~km}$ ENE of the Silenieki site $\left(25^{\circ} 30^{\prime} 53,938^{\prime \prime} \mathrm{E}\right.$ $\left.57^{\circ} 18^{\prime} 12,365^{\prime \prime N}\right)$. It displays supra-glacial meltout till, probably altered by gravity flow (Fig. 5.4). The supraglacial till consist of rare pebbles in an abundant matrix rich in sandy silt and clay. Till macrofabric is variable and poorly developed (Fig. 5.4). Nevertheless, some 
packages probably show different flow directions. In places bent lenses or chunks of silty sand can be encountered. The supraglacial till is underlain by pebbles with occasional cobbles and gravel admixture. This part of the section is similar to the composition of the uppermost part of the Silenieki section.

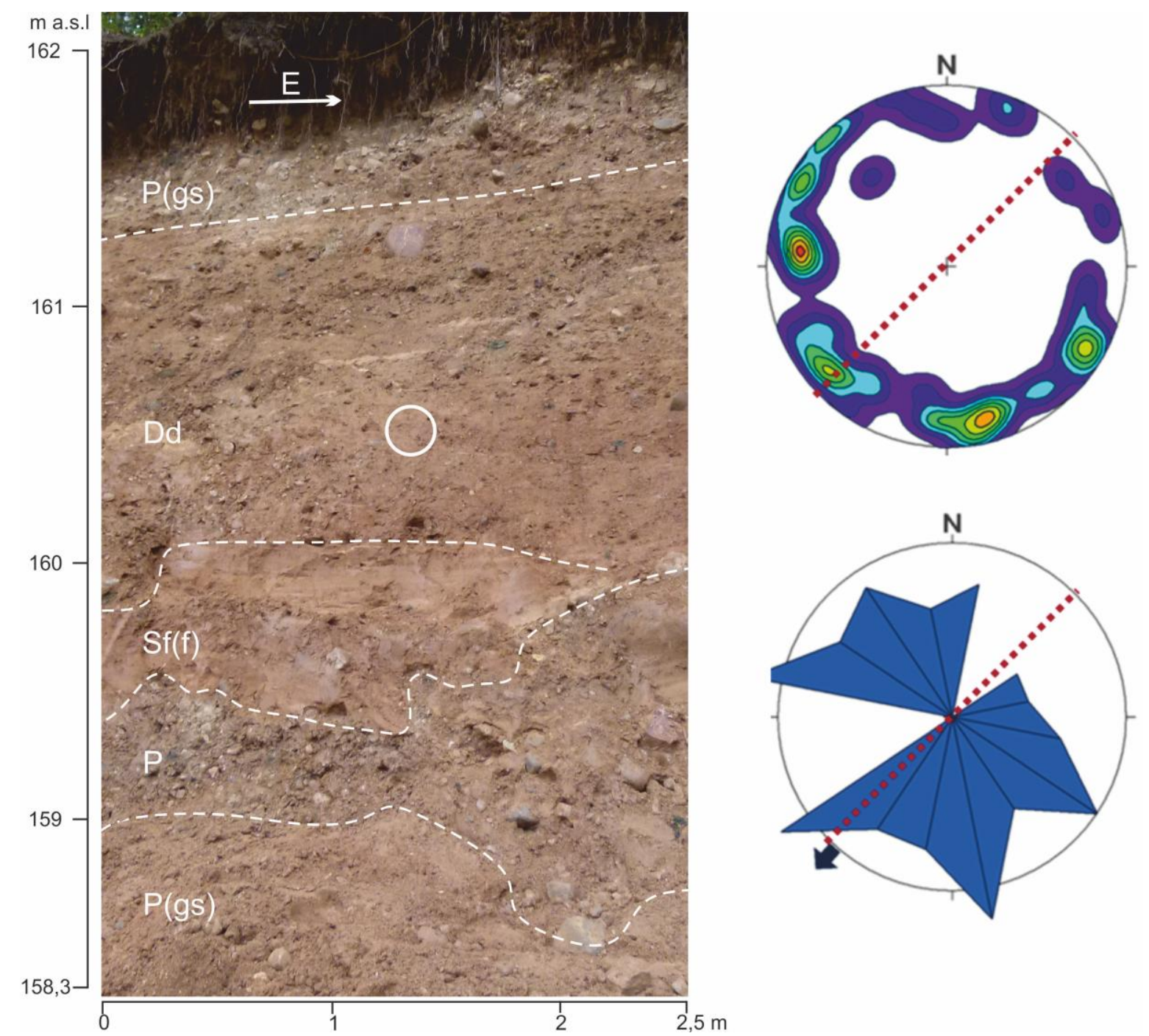

Fig. 5.4. Internal structure of the uppermost part of the Veselava end moraine in the Lỉbieši gravel pit and clast fabric diagram of the stratified diamicton.

Legend: Dd - diamicton with minor deformation structures, $\mathrm{P}$ - pebbles with occasional cobbles, $\mathrm{P}(\mathrm{gs})$ - pebbles with gravel admixture, $\mathrm{Sf}(\mathrm{f})$ - fine grained sand interlayered with silt. Large circle denotes macrofabric measurement site, red dotted line shows strike of ridge crest.

Three-dimensional diagram of macrofabric orientation is on the lower hemisphere and in equal area projection. Based on 50 macrofabric measurements. Contoured at $1-2 \ldots 8$ percent areas.

To sum up, the Veselava end moraine contains both mass-flow and waterlain sediments, and evidence of proglacial thrusting during small oscillations of the glacier terminus. Formation of ice-marginal moraines by a combination of proglacial thrusting and gravity processes (high sediment mobility) during the melting out of buried ice blocks is also suggested by Knight (2006). The morphometric parameters of the Veslava moraine most probably indicate that the glacier transported a large amount of drift with a high content of local bedrock fragments, and that glacier flow was relatively fast. In places, after glacier retreat, the end moraine ridge has been fragmented by subsequent fluvial erosion.

According a model of end moraine sedimentation based on data from Pleistocene ice 
sheet margins proposed by Krzyszkowski and Zieliński (2002), it can be classified as a B type end moraine, which represents "the most typical sequence in the end moraine zones" (Krzyszkowski and Zieliński ibid, p. 73). It is also possible that in some stretches of the Veselava end moraine where ice-marginal drainage has been hindered or promoted by proglacial topography, other types of end moraines may have developed.

\section{References}

Āboltinšs, O. 1972. Maršrut: Cesis - Veselava - Taurene - oz. Alauksts - oz. Zobols - Skujene - Nitaure - Ligatne Sigulda - Riga [Field trip Cesis - Veselava - Lake Alaksts Lake Zobols -Skuyene - Nitaure - Ligatne Cesis]. In: Danilāns, I., Āboltiňš, O. (eds.), Putevoditel polyevogo simpoziuma IV Vsesoyuznogo soveschanija po izucheniju krajevykh obrazovanij materikovogo oledenenija [Guide of the Field symposium of the IV All-Union meeting on studies of marginal formations of continental glaciation]. LGU im. P. Stučki, Rīga, pp. $47-59$ (in Russian).

Āboltinš, O. 1975. Glaciodynamic peculiarities of the formation of Latvian elevations. In: Danilans, I. (ed.), Problems of Quaternary geology, 8. Zinātne, Rīga, pp. 5-23 (in Russian, with English summary).

Āboltinš, O. P. 1989. Glyatsiostruktura i lednikovy morfogenez [Glaciotectonic structure and glacial morphogenesis]. Rìga: Zinātne, 284 pp. (In Russian).

Āboltiņš, O. 1995. Vidzeme Highland. In: Schirmer (ed.), INQUA 1995. Quaternary field trips in Central Europe. C-3 Baltic Traverse. Verlag Dr. Friedrich Pfeil, Munchen, Germany, pp. 159-162.

Āboltinšs, O., Straume, J., Juškevičs, V. 1975. Relief peculiarities and main stages of morphogenesis of Central Vidzeme Upland. In Danilāns, I. (ed.), Problems of Quaternary Geology, 8, Zinātne, Rīga, pp. 31-47 (in Russian, with English summary).

Āboltiņš, O.P., Veinbergs, I.G., Stelle, V.J., Eberhards, G.J. 1972. Osnovniye kompleksy marginal'nykh obrazovaniy i otstupaniye lednika na territorii Latviiskoy SSR [Main complexes of marginal formations and glacier retreat in the territory of Latvian SSR]. In: Goretskij, G. I., Pogulajev, D. I., Shick, S. M. (eds.), Krayevye obrazovaniya materikovykh oledeneniy [Marginal formations of continental glaciations]. Nauka, Moskva, pp. 30-37 (in Russian).

Bennett, M.M., Glasser, N.G. 2009. Glacial geology: ice sheets and landforms, 2nd edition. Wiley-Blackwell, 385 pp.

Krzyszkowski, D., Zieliński, T. 2002. The Pleistocene end moraine fans: controls on their sedimentation and location. Sedimentary geology, 2002, 73-92.

Knight, J. 2006. Geomorphic evidence for active and inactive phases of Late Devensian ice in north-central Ireland. Geomorphology, 75, 4-19.

Meirons, Z., Straume, J. 1979. Kaynozoyskaya grupa [Cenozoic group]. In: Misans, J., Brangulis, A., Danilans, I., Kuršs, V. (eds), Geologicheskoe stroyenie i poleznye iskopayemye Latvii [Geological structure and mineral resources of Latvia]. Zinātne, Rīga, pp. 176-268. (In Russian).

Meirons, Z., Straume, J., Juškevičs, V. 1976. Main varieties of the marginal formations and deglaciation of the Last glaciation in the territory of the Latvian SSR. In Danilāns, I. (ed.), Problems of Quaternary Geology, 9. Rīga, Zinātne, pp. 50-73 (in Russian, with English summary).

Nartišs, M., Zelčs, V. 2011. A succession of Lateglacial ice-dammed lakes in north Vidzeme, Latvia. In: Johansson, P., Lunkka, J.-P., Sarala, P. (eds.), Late Pleistocene Glacigenic Deposits from the Central Part of the Scandinavian Ice Sheet to Younger Dryas End Moraine Zone. Excursion Guide and Abstracts of the INQUA Peribaltic Working Group Meeting and Excursion in Finland, 12-17 June 2011. Geological Survey of Finland, Rovaniemi, p. 122.

Zelčs, V., Markots, A. 2004. Deglaciation history of Latvia. In: Ehlers, J., Gibbard, P. L. (eds.), Quaternary Glaciations - Extent and Chronology. Part I: Europe. Developments in Quaternary Science, 2. Elsevier, Amsterdam, pp. 225-243.

Zelčs, V., Markots, A., Nartišs, M., Saks, T. 2011. Chapter 18: Pleistocene Glaciations in Latvia. In: Ehlers, J., Gibbard, P.L., Hughes, P.D. (eds.), Quaternary glaciations - extent and chronology. A closer look. Developments in Quaternary Science, 15. Elsevier, pp. 221-229. 


\title{
STOP 6: Morphology, internal structure and texture of inland dunes at the Smilškalni site, Middle Gauja Lowland
}

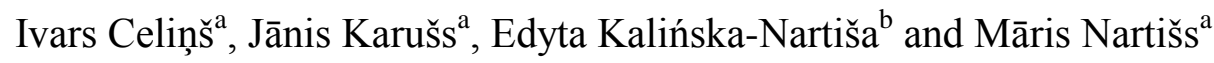 \\ ${ }^{\mathrm{a}}$ University of Latvia, Latvia \\ ${ }^{\mathrm{b}}$ University of Tartu, Estonia
}

\section{The geomorphological background of the site}

The Middle Gauja Lowland was formed by the Middle Gauja ice lobe of the Peipsijärv ice stream during the last, Weichselian glaciation (Zelčs and Markots 2004). Between the Gulbene (Middle Lithuania) and Linkuva (North Lithuania) deglaciation phases, dated to 15.5-14.5 ka (Kalm et al. 2011; Zelčs et al. 2011), the ice started to retreat and a large icedammed lake with a falling water level covered the lowland. An ice-dammed lake with a water level of $110 \mathrm{~m}$ a.s.l. covered most of the Middle Gauja Lowland. An abundance of glaciolacustrine sediments in some of the hypsometrically lower parts of the lowland indicates the presence of stagnant ice (Nartišs and Zelčs 2011). After the Linkuva reactivation of the Burtnieks lobe, ice continued to retreat and the Middle Gauja ice-dammed lake drained to the Smiltene ice-dammed lake and Strenči proglacial lake. During drainage, the water masses formed part of the valley of the River Gauja (Āboltinšs 1971; Nartišs and Zelčs 2011).

In most of the lowland a 10-20 m thick layer of Quaternary deposits covers the Upper Devonian bedrock. The lowermost part of the Quaternary sequence mainly consists of till. Across most of the lowland the till is overlain by glaciolacustrine fine-grained sand and silty sand in the central and southern part of the lowland, and by silty clay in the northern and north-eastern part (Juškevičs and Skrebels 2002). In some hypsometrically higher parts of the lowland varved clay up to $9 \mathrm{~m}$ thick can be found. In the whole of the Middle Gauja Lowland the topmost part of the glaciolacustrine sediments has been reworked by aeolian processes. However, dune landforms occur only in the southern and central part of the lowland. In other parts of this territory coversand up to $1 \mathrm{~m}$ thick overlies the older sediments.

\section{The distribution and morphology of the dunes}

Separate dunes are rare in the lowland. Most of dunes are concentrated in major dune complexes (Fig. 6.1). The later ones occupy the central and southern part of the lowland. The distribution of the inland dunes can be correlated with the area of sandy glaciolacustrine sediments; in areas with clay or silt sediments dunes are rare or absent. Significantly, the River Gauja valley represented a great obstacle for further migration of dunes to the east. Dune ridges stopped at the river valley and formed a very steep slope on the leeward side.

In total, 536 individual dune landforms were distinguished in the lowland. It is possible to distinguish 7 different dune complexes in the central and south part of the lowland. The concentration of dunes can reach up to 25 landforms per $\mathrm{km}^{2}$ in the central part of the lowland. The absolute heights of the dune bases vary from $65 \mathrm{~m}$ in the northern part up to 110 $\mathrm{m}$ a.s.l. at the Smilškalni site. The relative relief can reach up to $16.6 \mathrm{~m}$, but on average the dunes are $4.1 \mathrm{~m}$ high. Most of dunes are of compound or comb-parabolic shape, some of separate dunes being parabolic.

The azimuths of the long axes of the dunes were analysed in order to establish the main palaeowind directions. The results reveal minor variation in the wind directions between dune complexes. During the phase of dune stabilization in the Middle Gauja Lowland the main WE direction prevailed. 


\section{The internal structure of the Smilškalni dune}

A ground penetrating radar (GPR) Zond 12-e was used to determine the internal structure of the dune. GPR profiling was carried out using a common offset configuration with three antenna systems $-75 \mathrm{MHz}, 100 \mathrm{MHz}$ and $300 \mathrm{MHz}$. Data were recorded using $500 \mathrm{~ns}$ time windows, which correspond to approximately $30 \mathrm{~m}$, assuming that the real part of dielectric permittivity is 6 . The exact GPR profile length and its topography were measured at several points on the selected GPR profile line using a TopCon GRS-1 GPS/GNSS device.

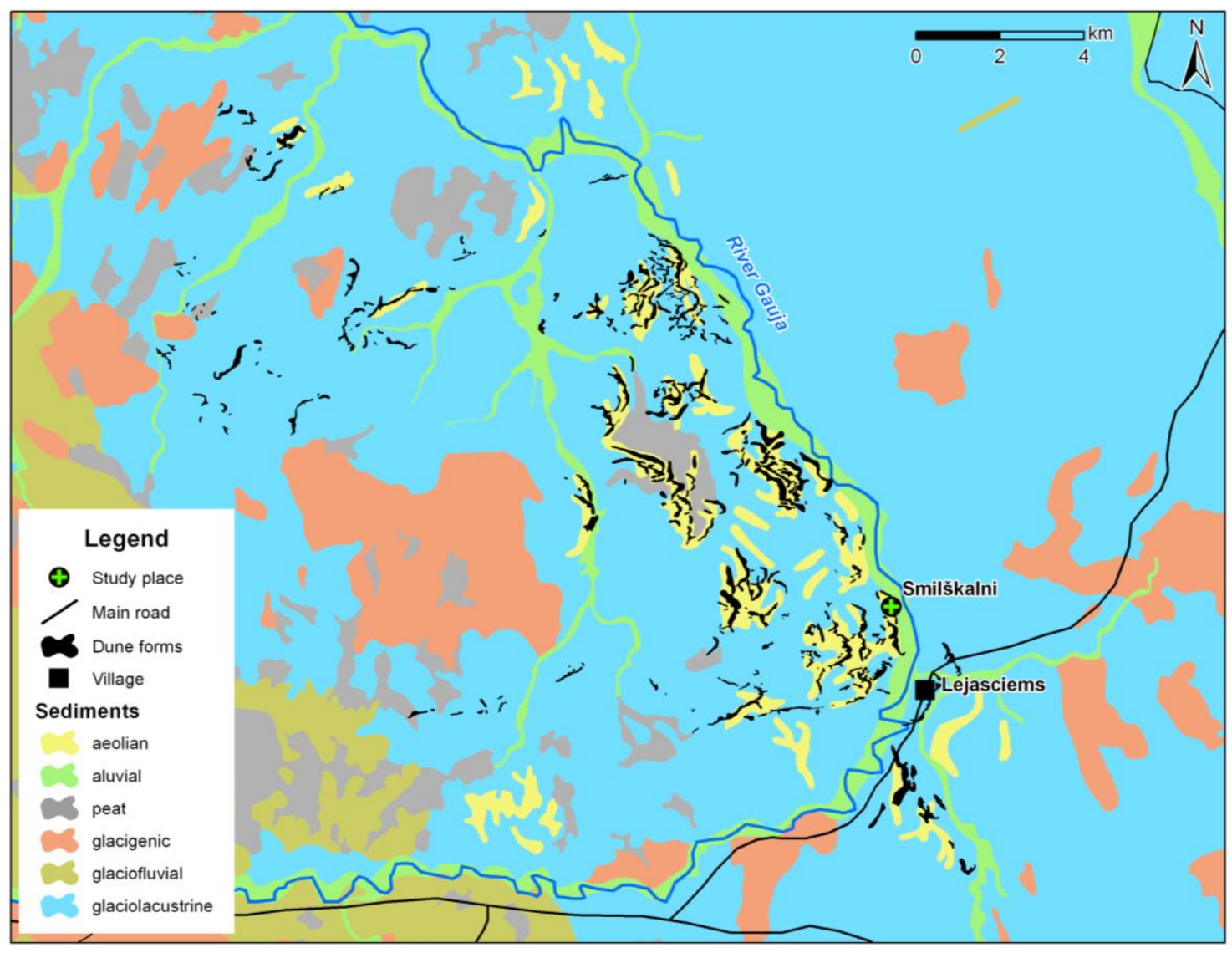

Fig. 6.1. The spatial arrangement of dunes in the central part of the lowland. Quaternary superficial deposits are shown according to Juškevičs and Skrebels (2002).

The GPR profiles were processed and analysed with Prism 2.5 software. To compensate for signal losses during propagation through the ground, the time-dependent signal gain function was used. Also, the Ormsby band-pass filter was used to extract the part of the frequency spectrum that contains informative signals. Simultaneously, the background removal filter was used to delete horizontal uninformative signals. To compensate for the time dilation arising from the fact that the transmitter and receiver antennas were separated by some distance during GPR profiling, a moveout correction was applied (Neal 2004). As the last step in GPR profile processing topographic correction was applied using the obtained GPS measurements.

During research GPR profiles of high quality were obtained. In contrast to the profiles based on the 100 and $300 \mathrm{MHz}$ antennas, the $75 \mathrm{MHz}$ antenna GPR profile revealed more subsurface information. Thus, detailed analysis was carried out on the GPR profile obtained with the $75 \mathrm{MHz}$ antenna system.

Several informative signals were identified (Fig. 6.2). The first signal (indicated by arrow No. 1 in Fig. 6.2) relates to the boundary between sediment layers with significant differences in 
electromagnetic properties. Additionally, it was possible to identify signals related to crossbedding on the lee side of the dune (No. 2 in Fig. 6.2) and a signal reflected from the groundwater level (No. 3 in Fig. 6.2). The fourth and fifth signals (No. 4 and 5 in Fig. 6.2) were reflected from the above surface objects and are considered uninformative signals.

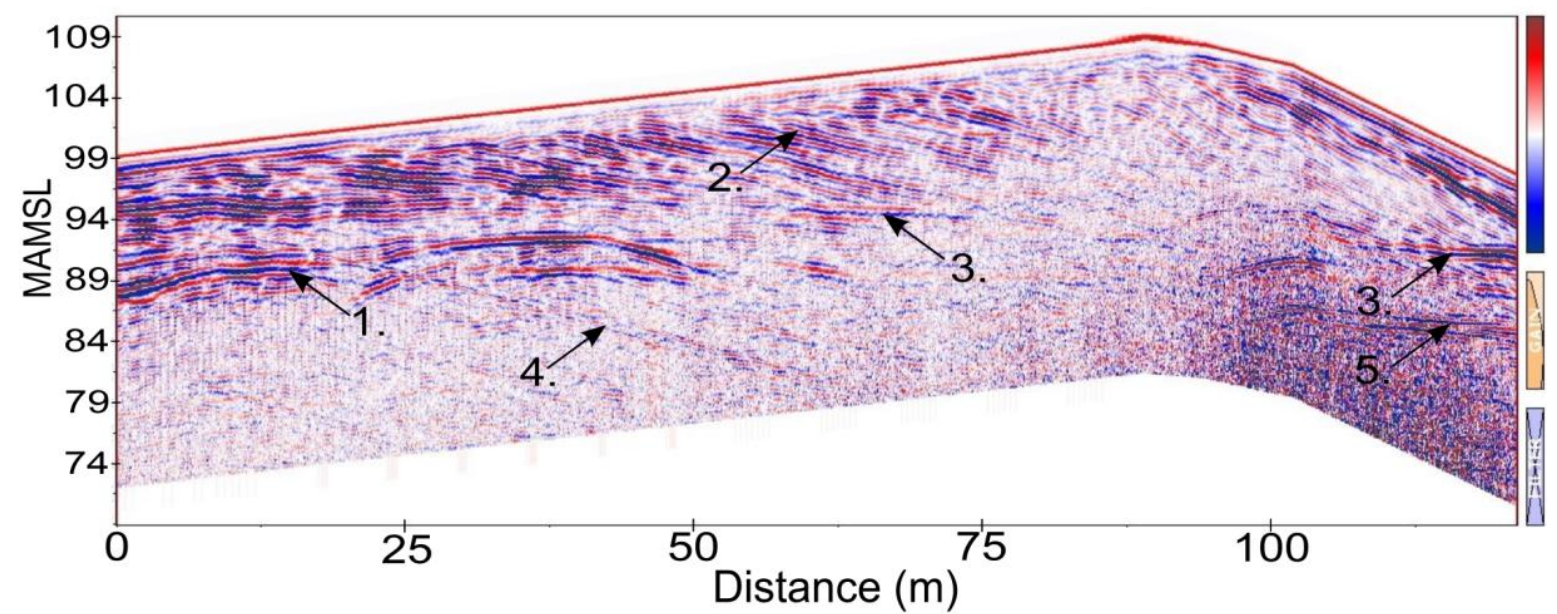

Fig. 6.2. The GPR profile of Smilškalni dune.

The dip and azimuth of dune cross-beddings were measured at 20 places in the outcrop of the Smilškalni site. Most of the dune cross-beddings dip at $14^{\circ}$ to $30^{\circ}$, indicating the lee side of the dune, and active dune migration before stabilization. These results were also in quite good agreement with observations of the dune long axis. In the lowermost part of the dune the dip of the sand beds is subhorizontal, with an angle of $3^{\circ}$ to $4^{\circ}$.

\section{The textural features of aeolian sediments of the Smilškalni dune}

The shape and surface features of quartz grains (Shrivastava et al. 2012; Vos et al. 2014) together with the grain size parameters (Vandenberghe 2013; Zhu et al. 2014) can serve as a powerful tool in deciphering the depositional environment and mode of transportation of sediments as well as their origin and classification. A multidisciplinary set of methods was applied to the Smilškalni site: (1) grain-size distribution of sediments, (2) rounding of the quartz grains and character of the quartz grain surface in the sandy fractions $(0.5-0.8,0.8-1.0$ $\mathrm{mm}$ and $>1.0 \mathrm{~mm}$ ), (3) mineral-petrographic composition in the sandy fractions. A total of two sediment sequences - upper and lower Smilškalni - were investigated.

Grain-size analysis was performed by sieving, using sieve sizes $4.0 ; 2.0 ; 1.0 ; 0.8 ; 0.5$; $0.315 ; 0.25 ; 0.2 ; 0.125 ; 0.1$ and $0.063 \mathrm{~mm}$. Based on analysis of the distribution of the size composition, logarithmic Folk and Ward (1957) graphical measures were obtained. Within the sand fraction $(0.5-0.8,0.8-1.0$ and $>1.0 \mathrm{~mm})$ quartz grains were subjected to analysis of rounding and surface frosting/mattness following two independent methodologies: (1) Mycielska-Dowgiałło and Woronko (1998) with the modification proposed by Kalińska and Nartišs (2014), and (2) Velichko and Timirieva (1995).

The mean grain size $(\mathrm{Mz})$ of the dune sand samples in the Smilškalni averages $2.07 \varphi$, with a range of $1.78 \varphi$ to $2.36 \varphi$. Simultaneously a tendency to become finer is observed in the lower part of the dune, where the average $2.35 \varphi$ of the mean is observed. Similarly, a higher sorting value $(\sigma=0.57)$ is noted in the lower part of the profile. This pattern is likely to reflect the dune-parent material relationship, where enrichment in relatively coarse grains is noted due to the selective removal of grains from substratum, something observed in numerous aeolian environments (Folk 1971; Mycielska-Dowgiałło and Ludwikowska-Kędzia 2011; 
Mycielska-Dowgiałło 2007).

Along with the rounding and surface character of quartz grains, a predominance of the aeolian factor is observed, indicated both by long-duration abrasion and/or long transport distance (RM type of grains), and short-duration abrasion and/or short transportation (EM/RM type of grains) within both sequences. The total content of such grains varies between 29.06$70.68 \%$. Simultaneously, a relatively high proportion, between $8.89-24.74 \%$, of perfectly rounded matt $(\mathrm{RM})$ grains is observed in the Smilškalni lower sequence. In general, the presence of numerous well-rounded concavities with a frosted appearance is considered a diagnostic indicator of intensive aeolian transformation (Swezey 1998). However, in terms he the outline of the remaining quartz grains observed within the investigated profiles do not conform to this pattern (see below), which rather points either to inheritance from the former environments or to the chemical solution and redeposition of silica. The latter has been proven experimentally by Kuenen and Perdok (1962) as leading to the rounding of quartz grains.

Grains with an angular outline are generally considered to be absent in the aeolian environment (Vos et al. 2014). However, there is a high content between, 21.80 to $50.00 \%$, of NU/M type grains, with sharp edges and a matt surface. Abundant NU/M quartz grains, noted in the Smilškalni upper sequence, are characterised by two features: (1) their angularity, with definitely sharp edges, and (2) their specific surface character, which under the binocular microscope resembles frosting. Indeed, the seasonal freezing of fluids causes splitting-off, and an uneven, shelly surface can be created; such grains have been observed frequently within palaeosols of loess sequences (Velichko and Timirieva 1995). Furthermore, the ubiquitous (between 14.44-34.00\%) presence of C-type (cracked) quartz grains can be explained through inheritance from local glacial/glaciofluvial lithologies, these standing in close relation to the aeolian deposits.

Application of the second independent methodology, after Velichko and Timirieva (1995), to the $>1.0 \mathrm{~mm}$ quartz fraction, revealed the aeolian nature of the investigated sequences. Completely matt and 50\% matt grains in the 3rd and 4th group of roundness, in accordance with Rukhin's (1961) classification, prevail; thus, the mattness and roundness indexes are relatively high in the Smilškalni upper sequence in particular. The outline roundness of quartz grains seems to be positively correlated with the size of the grains, indicating that aeolian transformation has affected predominantly the bigger quartz grains.

Notable is the occurrence of a significant quantity of feldspars in the investigated sequences. This suggests that the major part of the sediment has not passed through several sedimentary cycles and is instead derived directly from igneous and metamorphic rocks. Furthermore, this presumably supports the idea of immaturity, mixing and dependence upon the original formations that supplied the investigated profiles.

\section{The timing of aeolian activity}

A total of four sand samples from the Smilškalni site were processed by the optically stimulated luminescence (OSL) method using a single-aliquot regenerative dose (SAR) protocol (Murray and Wintle 2000; Wintle and Murray 2006). Samples were processed at the Nordic Laboratory for Luminescence Dating. The obtained results indicate a long time span of aeolian activity - starting from $13.71 \pm 1.01 \mathrm{ka}$ up to $10.6 \pm 0.8 \mathrm{ka}$ (unpublished data).

Notably, both textural and structural features of the dune do not indicate a long hiatus with subsequent reactivation of aeolian processes. This indicates low-intensity aeolian processes lasting a few thousands of years. In spite of the longevity of aeolian processes, the absence of palaeosol levels or any organic matter in the aeolian sediments should be noted. 


\section{References}

Āboltiňš, O. 1971. Razvitije dolini reki Gauya [Development of the River Gauja valley]. Zinātne, Rīga, 105 pp. (In Russian)

Folk, R.L. 1971. Longitudinal dunes of the northwestern edge of the Simpson Desert, Northern Territory, Australia. 1. Geomorphology and grain size relationships. Sedimentology, 16(1-2), 5-54.

Folk, R.L., Ward, W.C. 1957. Brazos River Bar: A Study in the Significance of Grain Size Parameters. Journal of Sedimentary Petrology, 27, 3-26.

Juškevičs, V., Skrebels, J. 2002. Quaternary sediments. In: Āboltiņš, O., Brangulis, A.J. (eds.), Geological map of Latvia. Scale 1:200,000. Sheets 44-Alūksne, 45-Vilıka, 54-Valka. Explanatory text and maps. State Geological Survey, Rīga, pp. 9-27.

Kalińska, E., Nartišs, M. 2014. Pleistocene and Holocene aeolian sediments of different location and geological history: A new insight from rounding and frosting of quartz grains. Quaternary International, 328-329, 311-322.

Kalm, V., Raukas, A., Rattas, M., Lasberg, K., 2011. Pleistocene Glaciations in Estonia, In: Ehlers, J., Gibbard, P.L., Hughes, P.D. (eds.), Quaternary glaciations - extent and chronology. A closer look. Developments in Quaternary Science, 15. Elsevier, pp. 95-104.

Kuenen, Ph.H., Perdok, W.G. 1962. Experimental abrasion 5. Frosting and defrosting of quartz grains. Journal of Geology, 70(6), 648-658.

Murray, A.S., Wintle, A.G. 2000. Luminescence dating of quartz using an improved single-aliquot regenerativedose protocol. Radiation Measurements 32, 57-73.

Mycielska-Dowgiałło, E. Woronko, B. 1998. Analiza obtoczenia i zmatowienia powierzchni ziarn kwarcowych frakcji piaszczystej i jej wartość interpretacyjna. Przegląd Geologiczny 46, 1275-1281.

Mycielska-Dowgiałło, E. 2007. Metody badań cech teksturalnych osadów klastycznych i wartość interpretacyjna wyników, in: Mycielska-Dowgiałło, E., Rutkowski, J. (eds.), Badania Cech Teksturalnych Osadów Czwartorzędowych i Wybrane Metody Oznaczania Ich Wieku. WSWPR, pp. 95-189.

Mycielska-Dowgiałło, E., Ludwikowska-Kędzia, M. 2011. Alternative interpretations of grain-size data from Quaternary deposits. Geologos, 17, 189-203.

Nartišs, M., Zelčs, V. 2011. A succession of Lateglacial ice-dammed lakes in north Vidzeme, Latvia. In: Johansson, P., Lunkka, J.-P., Sarala, P. (eds.), Late Pleistocene Glacigenic Deposits from the Central Part of the Scandinavian Ice Sheet to Younger Dryas End Moraine Zone. Excursion Guide and Abstracts of the INQUA Peribaltic Working Group Meeting and Excursion in Finland, 12-17 June 2011. Geological Survey of Finland, Rovaniemi, p. 122.

Neal, A. 2004. Ground-penetrating radar and its use in sedimentology: principles, problems and progress. EarthScience Reviews, 66, 261-330.

Rukhin, L.B. 1961. Principles in lithology. Gostoptekhizdat, Leningrad, 779 pp.

Shrivastava, P.K., Asthana, R., Roy, S.K., Swain, A.K., Dharwadkar, A. 2012. Provenance and depositional environment of epi-shelf lake sediment from Schirmacher Oasis, East Antarctica, vis-à-vis scanning electron microscopy of quartz grain, size distribution and chemical parameters. Polar Science, 6, 165182.

Swezey, C.S. 1998. The identification of eolian sands and sandstones. Comptes Rendus de l'Academie des Sciences - Series IIA - Earth and Planetary Science, 327(8), 513-518.

Vandenberghe, J. 2013. Grain size of fine-grained windblown sediment: A powerful proxy for process identification. Earth-Science Reviews, 121, 18-30.

Velichko, A.A., Timirieva, S.N. 1995. Morphoscopy and morphometry of quartz grains from loess and buried soil layers. GeoJournal, 36, 143-149.

Vos, K., Vandenberghe, N., Elsen, J. 2014. Surface textural analysis of quartz grains by scanning electron microscopy (SEM): From sample preparation to environmental interpretation. Earth-Science Reviews, $128,93-104$.

Wintle, A.G., Murray, A.S. 2006. A review of quartz optically stimulated luminescence characteristics and their relevance in single-aliquot regeneration dating protocols. Radiation Measurements, 41(4), 369-391.

Zelčs, V., Markots, A. 2004. Deglaciation history of Latvia. In: Ehlers, J., Gibbard, P. L. (eds.), Quaternary Glaciations - Extent and Chronology. Part I: Europe. Developments in Quaternary Science, 2. Elsevier, Amsterdam, pp. 225-243.

Zelčs, V., Markots, A., Nartišs, M., Saks, T. 2011. Chapter 18: Pleistocene Glaciations in Latvia. In: Ehlers, J., Gibbard, P.L., Hughes, P.D. (eds.), Quaternary glaciations - extent and chronology. A closer look. Developments in Quaternary Science, 15. Elsevier, pp. 221-229.

Zhu, B.Q., Yu, J.J., Rioual, P., Ren, X.Z. 2014. Particle size variation of aeolian dune deposits in the lower reaches of the Heihe River basin, China. Sedimentary Geology, 301, 54-69. 


\section{STOP 7: Madona-Trepe ice-marginal ridge at Smeceres sils, East-Latvian Lowland}

Vitālijs Zelčs, Māris Krievāns and Māris Nartišs

University of Latvia

The Madona-Trepe ice-marginal ridge (Fig. 7.1) is the most prominent ice-marginal formation in Latvia. This spectacular moraine ridge, generally oblique to streamlined landforms (megaflutes to mega-lineations), marks the maximum extent of the Lubāns ice lobe during the Gulbene deglacilation phase in the East-Latvian Lowland (Meirons et al. 1976; Zelčs and Markots 2004; Zelčs et al. 2011).

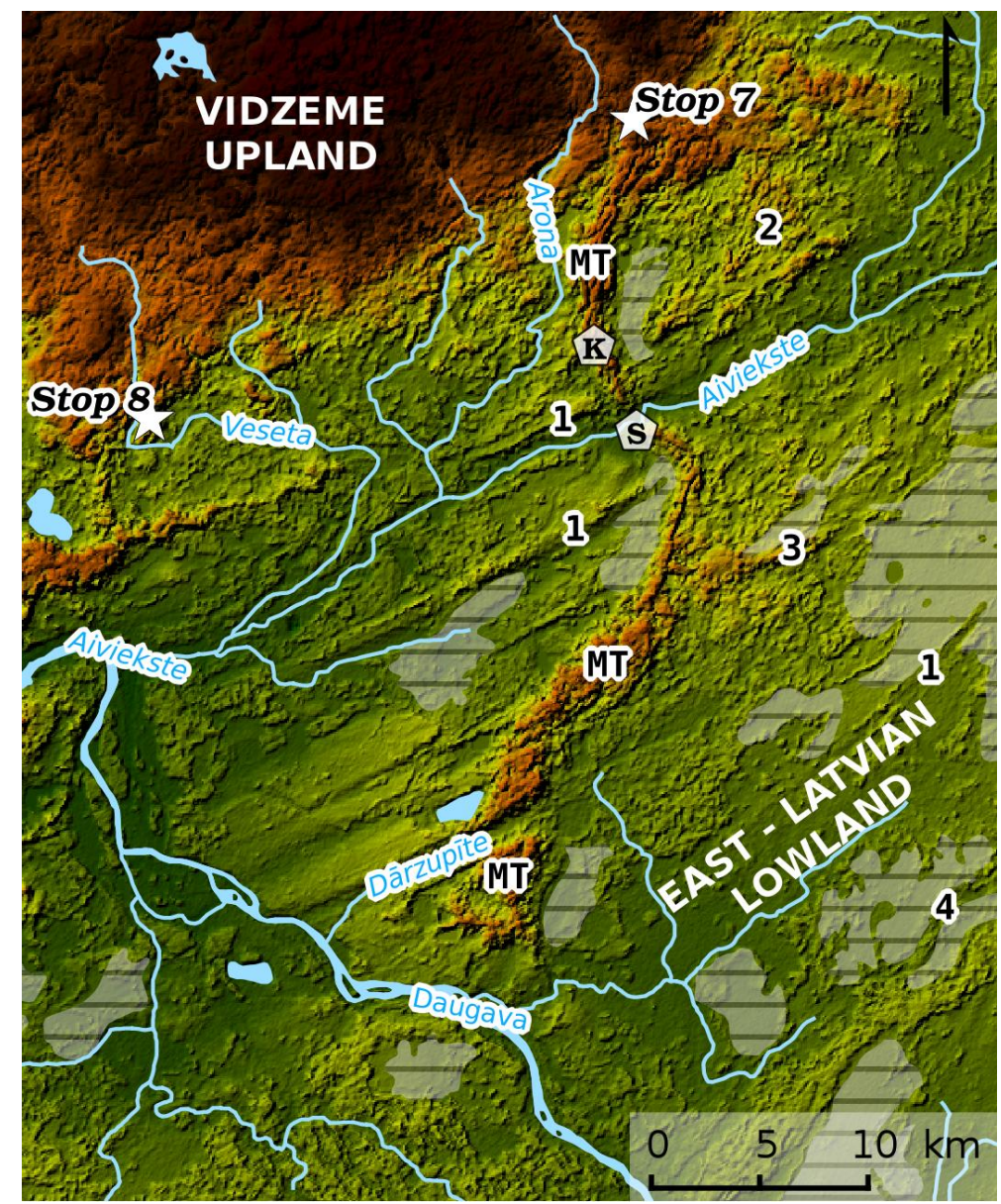

Fig. 7.1. SRTM DEM of the glacial terrain along the Madona-Trepe ice-marginal ridge. Note that megaflutes and megascale lineations are superimposed by small recessional moraine ridges. Legend: MT - Madona-Trepe ridge; K - Krustkalni gravel pit; S - Sāviena gravel pit; 1 - megaflutes and megascale lineations; 2 - hummocky topography; 3 - lateral shear marginal moraine; 4 - esker.

The Madona-Trepe ridge stretches for a distance of $45 \mathrm{~km}$ between the east-Latvian stretch of the River Daugava valley and the outer slope of the Vidzeme Upland, associated with a belt of lateral moraine ridges (so-called oriented marginal relief of the peripheral zone after Āboltiņš et al. 1975; Āboltinšs 1995) modified by meltwater discharge. Deeply incised transverse meltwater drainage channels, probably tunnel valleys, maintained nowadays by the Rivers Aiviekste and Dārzupite, and the dry valley next to Stop 7 at Smeceres sils (2609'54"E, 56 49'39"N), split the Madona-Trepe ridge into four parts. On both sides of the dry valley the highest points of the surface topography slightly exceed $170 \mathrm{~m}$ a.s.l. and rise 
almost $70 \mathrm{~m}$ above proximal ice-scooped basins occupied by lakes and mires, a distally located ice-marginal drainage channel and large glaciokarst kettles. The elevation and local relief fall away in the direction of the River Daugava valley, i.e. the centre line of the ice lobe terminus. The width of the Madona-Trepe ridge varies from $0.7 \mathrm{~km}$ to $5 \mathrm{~km}$. South of the dry valley its surface is undulated by $2-50 \mathrm{~m}$ high, subparallel or parallel elongated ramparts. Their roughly NNE-SSW strike corresponds to the general orientation of the ice-marginal ridge.

The Madona-Trepe ice-marginal ridge is situated on an elongated bedrock rise. It lies about $80 \mathrm{~m}$ a.s.l. in its more elevated part, and gradually lowers to $50 \mathrm{~m}$ a.s.l. in the direction of the centre line of the Lubāns lobe terminus. The bedrock consists of Upper Devonian terrigenous deposits, but $\mathrm{S}$ of the dry valley these are replaced by carbonate rocks. The complex of Weichselian sediments, mainly waterlain, that overlies the bedrock, is $80-90 \mathrm{~m}$ thick in the morphologically more expressed part, thinning towards the SSW to $40-50 \mathrm{~m}$. Here it is at least twice or up to four times thicker than in the adjoining proximally located ice-scooped basins and glacially megalineated terrain.

The internal structure has been examined in several gravel quarries located in different parts of the ice-marginal ridge. There is no substantial difference in lithological composition between these parts of the ridge, but they differ greatly in their internal architecture, as explained below.

The coarse material (gravel, gravel and pebbles with sand), which forms most of the exposed sequence, is underlain by thinly laminated sandy sediments, which make up the lowermost part of the exposed sections. In places the coarse sediments are interlayered with sand up to 2-3 m thick, with intercalations of finer material (Fig. 7.2: I) and containing occasional gravel and dispersed small pebbles in the lower part of the interlayer. The laminated sandy sediments also occur in an enormous area along both sides of the Madona-Trepe ridge, also

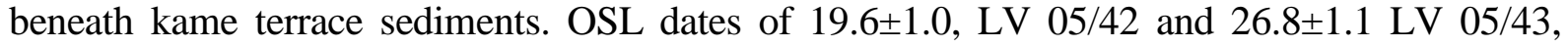
obtained from the interlayer of sand (Fig. 7.2: II) in the Smeceres sils quarry, suggest that they were most probably deposited slightly before and/or during the maximum transgression of the Late Weichselian glaciation in this area (Raukas et al. 2010). However, the burial OSL age of the thinly laminated sand deposited in the lower part of two other sections $(46.0 \pm 8.6 ; 41.4 \pm 8.6$; $49 \pm 22$; due to very wide paleodose distributions, the results should be considered only as age estimates), located in a small ice-pushed ridge and lateral shear moraine moraine, yield evidence of deposition during the Middle-Weichselian interstadial.

Four recently studied sections (Fig. 7.2), situated at levels from $169 \mathrm{~m}$ a.s.1. to $153 \mathrm{~m}$ a.s.l. in the gravel quarry at the Smeceres sils, reveal the internal structure of the northern stretch of the Madona-Trepe ice-marginal ridge. In general, the internal structure of the ridge has been altered only by limited glaciotectonic deformation and by mass sliding and flowage, which is encountered on the ENE slope (Fig. 7.2: IV). Coarsening upwards of the coarse sequence (Fig. 7.2: I) can be explained by the acceleration of ice melt, resulting in boulder concentration, in some cases also in the formation of a boulder pavement on the topmost part, and in the appearance of scattered boulders on the distal slope of the ice-marginal ridge. Besides this, cobbles and boulders have been altered to some extent by frost weathering and covered by coversand. The upper coarse sequence rests on up to 2-3 m thick, predominantly medium- to fine-grained sand with intercalations of silt and clay strings (Fig. 7.2: II). The sand has been OSL dated (Raukas et al. 2010). The underlying gravel bed is interlayered with sand, which contains occasional gravel strings and dispersed small pebbles (Fig. 7.2: III). According to bedding plane measurement data, it is more likely that the exposed sediments represent icemarginal fan deposition. The ridge slope consists of supraglacial melt-out and gravity flow till in places with lenses of meltwater sediments underlain by laminated sand (Fig. 7.2: IV). 

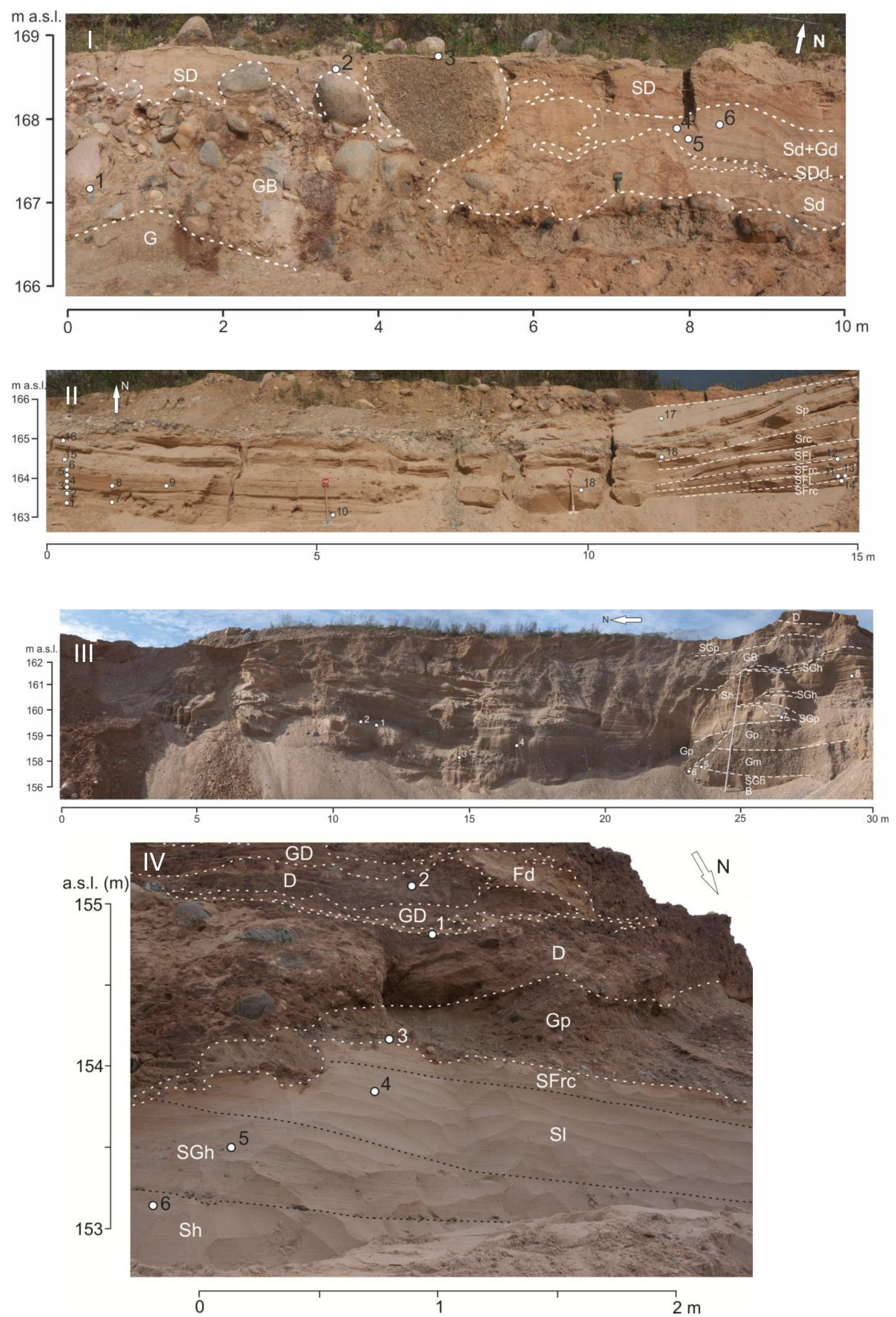

Fig. 7.2. Internal structure of the Madona-Trepe ice-marginal ridge at Smeceres sils in the exposures of the gravel pit located next to the dry meltwater discharge valley. Note that the sections are located at different elevation. White dots and numbers denote measurement sites of the bedding planes and glacial striation; D diamicton; B - boulders; G - gravel; Gd - deformed gravel; $\mathrm{Gm}$ - massive gravel; $\mathrm{Gp}$ - planar cross-stratified gravel; GD - diamictic gravel; GB - bouldery gravel; Sd - deformed sand; Sh - horizontally bedded sand; Sl - 
low-angle cross-bedded sand; Sp - planar cross-bedded sand; Src - subcritically climbing-ripple cross-laminated sand; SD - diamictic sand; SDd - deformed diamictic sand; SGh - horizontally bedded gravelly sand; SGp planar cross-stratified gravelly sand; SFl - low-angle cross-bedded sand with fines; SFrc - climbing ripple crosslaminated sand with fines; Fd - deformed silt. I. Gravel with cobbles and boulders altered to some extent by frost weathering, underlain by gravel with dispersed pebbles and covered by coversand; II. Up to $2-3 \mathrm{~m}$ thick, predominantly medium- to fine-grained sand with intercalations of silt and clay strings, OSL dated (Raukas et al. 2010); III. Gravel interlayered with sand, containing occasional gravel strings in some interlayers; IV. Supraglacial melt-out and gravity flow till in places with lenses of meltwater sediments underlain by the laminated sand.

The internal structure reveals that between the dry valley at Smeceres sils and the River Aiviekste valley recessional megablock and thrusted scale sheets are dominant. These glaciotectonic deformation structures mainly consist of gravel with an admixture of pebbles, gravel with sand, and occasional interlayers of gravelly sand. Common south of the River Aiviekste valley up to the Dārzupîte are large inclined and overturned folds, fold-faults and overthrusts with plastering of till on the upglacier side. These differences in internal structure, their spatial succession and the morphological peculiarities of the distinct parts of the Madona-Trepe ice-marginal ridge, in the light of the recent studies done by Evans et al. (2008, 2014) and Krüger et al. (2010), suggest quite different circumstances along the terminus of the Lubāns lobe during the Gulbene oscillation phase. In the segments of glacial recession glaciotectonic shortening prevailed due to compressive ice basal motion, while along the centre line of the ice lobe terminus the glacier has overridden smoothed and, possibly, buried push moraines.

The topography of the Madona-Trepe ridge and the terrain beyond and behind it resembles to a great extent the Wolf Lake vicinity, Alberta, described by Andriashek and Fenton (1989). Besides, as seen in Fig. 7.1, the Madona-Trepe ridge is curved, forming arcuate clusters. This morpholological feature indicates differentiation of the ice basal marginward motion in the transverse section of the Lubāns lobe in a similar manner to that suggested by Stephan (1985: Fig. 3) in a block movement model for glacier pushing. Lowering and widening of the ridge, and thinning of the landforming sediments in the direction of the centre line of the Lubāns lobe terminus can be explained by the mechanism noted by Krüger et al. (2010). They report (ibid.), that "the most prominent ice-marginal ridges under formation were seen where the advancing glacier pushed against a rather thick body of hochsander fan deposits or a frontal ramp of mass-movement deposits. Where the glacier overrode ground moraine, the ice-marginal ridge was commonly small, probably because the glacier toe, when overriding ground moraine, was almost at the same level as the till surface beyond." Taking into account that in the case under consideration stratified gravelly sediments form a thick body and occur in a vast area on the upglacier and downglacier sides of the Madona-Trepe ice marginal ridge, they have been interpreted as most probably constituting outwash (excluding the part $\mathrm{N}$ of the dry valley).

\section{References}

Āboltiňš, O. 1995. Vidzeme Highland. In: Schirmer (ed.), INQUA 1995. Quaternary field trips in Central Europe. C-3 Baltic Traverse. Verlag Dr. Friedrich Pfeil, Munchen, Germany, pp. 159-162.

Āboltiňš, O., Straume, J., Juškevičs, V. 1975. Relief peculiarities and main stages of morphogenesis of Central Vidzeme Upland. In Danilāns, I. (ed.), Problems of Quaternary Geology, 8, Zinātne, Rīga, pp. 31-47 (in Russian, with English summary).

Andriashek, L.D., Fenton, M.M. 1989. Quaternary stratigraphy and surficial geology, Sand River Map Sheet 73L, Alberta. Bulletin, 057. Alberta Research Council and the Alberta Geological Survey and Terrain Sciences Department. Edmonton AB, 165 pp.

Evans, D.J.A., Clark C.D., Rea, B.R. 2008. Landform and sediment imprints of fast glacier flow in the southwest Laurentide Ice Sheet. Journal of Quaternary Science, 23(3), 149-272. 
Evans, D.J.A., Young, N.J.P., Ó Cofaigh, C. 2014. Glacial geomorphology of terrestrial-terminating fast flow lobes/ice stream margins in the southwest Laurentide Ice Sheet. Geomorphology, 204, 86-113.

Juškevičs, V., Skrebels, J. 2003. Quaternary deposits. In: Āboltiņš, O., Brangulis, A.J. (eds.), Geological Map of Latvia. Scale 1:200,000. Sheet 34-Jēkabpils. Sheet 24-Daugavpils. Explanatory Text and Maps. State Geological Survey, Rīga, pp. 10-29.

Krüger, J., Schomaker, A., Benediktsson, Í.Ö. 2010. Ice marginal environments: geomorphic and structural genesis of marginal moraines at Mýrdalsjökull. In: Schomaker, A., Krüger, J., Kjær, K.H. (eds.), The Mýrdalsjökull Ice Cap, Iceland. Glacial processes, sediments and landforms on an active volcano. Developments in Quaternary Sciences, 13, pp. 79-104.

Meirons, Z., Straume, J., Juškevičs, V. 1976. Main varieties of the marginal formations and deglaciation of the Last glaciation in the territory of the Latvian SSR. In Danilāns, I. (ed.), Problems of Quaternary Geology, 9. Rīga, Zinātne, pp. 50-73 (in Russian, with English summary).

Raukas, A., Stankowski ,W. T. J.; Zelčs, V., Šinkūnas, P. 2010. Chronology of the last deglaciation in the Southeastern Baltic region on the basis of recent OSL dates. Geochronometria, 36, p. 47-54.

Stephan, H.-J. 1985. Deformation striking parallel to glacier movement as a problem in reconstructing its direction. Geological Society Denmark Bulletin, 34, 47-53.

Zelčs, V., Markots, A. 2004. Deglaciation history of Latvia. In: Ehlers, J., Gibbard, P. L. (eds.), Quaternary Glaciations - Extent and Chronology. Part I: Europe. Developments in Quaternary Science, 2. Elsevier, Amsterdam, pp. 225-243.

Zelčs, V., Markots, A., Nartišs, M., Saks, T. 2011. Chapter 18: Pleistocene Glaciations in Latvia. In: Ehlers, J., Gibbard, P.L., Hughes, P.D. (eds.), Quaternary glaciations - extent and chronology. A closer look. Developments in Quaternary Science, 15. Elsevier, pp. 221-229. 


\section{STOP 8: Morphology and arrangement of glaciokarst kettles at Vietalva village}

Jānis Karušs, Māris Krievāns and Agnis Rečs

University of Latvia

The stop site at the glaciokarst kettles $\left(25^{\circ} 47^{\prime} 59^{\prime \prime} \mathrm{E}, 56^{\circ} 42^{\prime} 58^{\prime \prime} \mathrm{N}\right)$ is located about $2 \mathrm{~km} \mathrm{~S}$ of Vietalva village, at the SW corner of the Vidzeme Upland, in the transition zone to the East-Latvian Lowland. The toponym Vietalvas katli ('Vietalva Kettles') signifies the peculiar topography of this area. According to Dauškans (2011), this small area (about $10 \mathrm{~km}^{2}$ ) contains 98 kettle holes (Fig. 8.1). The maximum depth of the individual kettles is up to $30 \mathrm{~m}$. The kettle slopes are predominantly very steep and in some places reach the critical angle of repose. In this case the slopes are complicated by topographic forms resembling small-scale landslides or exhibit other finer-scale mass wasting features.

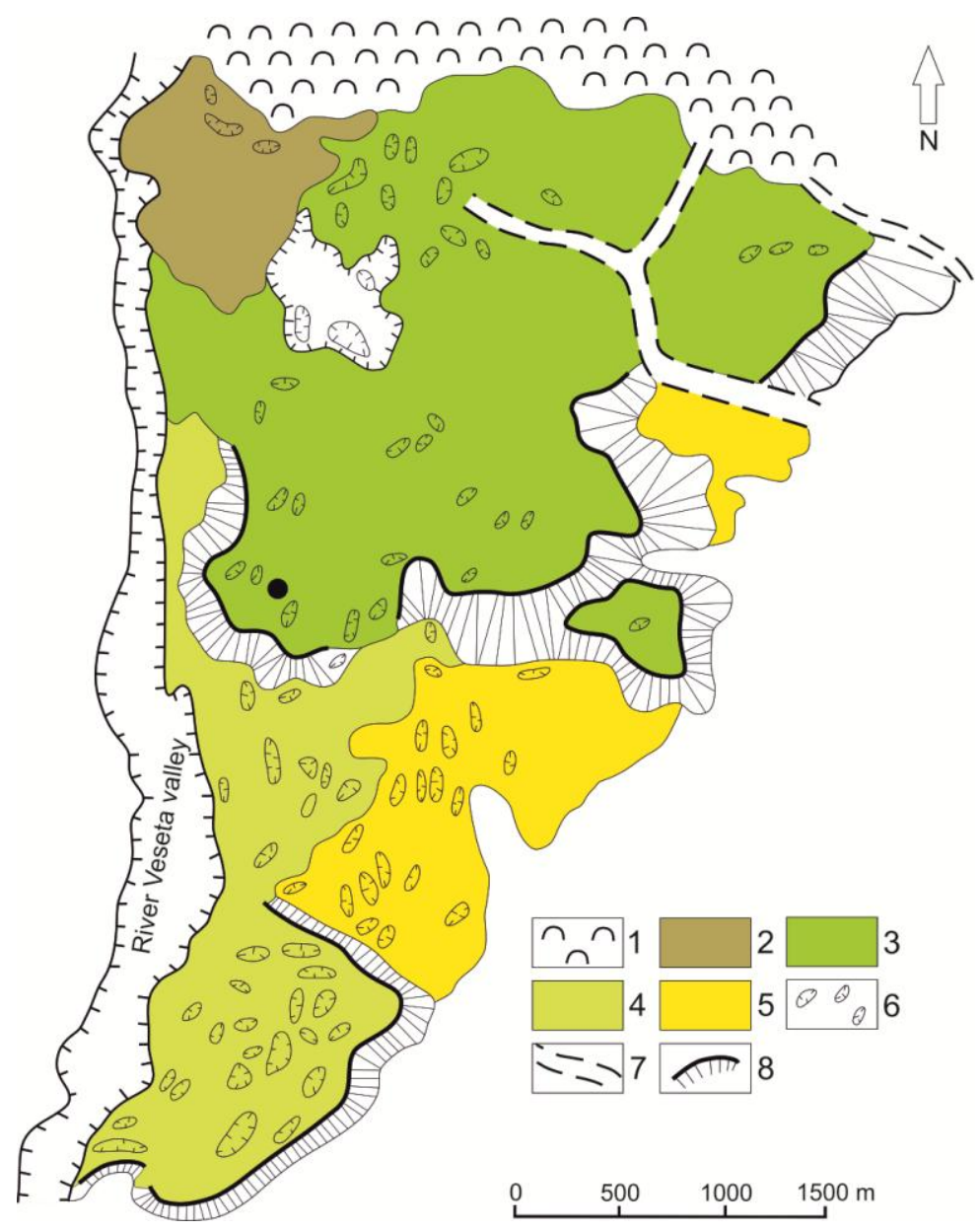

Fig. 8.1. Morphological features of the surface topography of the stretch of the Jānukalns (Veckalsnava) kame terrace along the left bank of the River Veseta. Modified by the authors after Straume (1979) and Dauškans (2013). Legend: 1 - interlobate hummocky moraine; 2-5 kame terrace levels: 2 - highest, 3 - higher, 4 medium, 5 - lower; 6 - major glaciokarst kettles; 7 - drainage channels; 8 - ice contact slopes. Black circle denotes stop site.

In the Vietalva kettle area the bedrock surface is composed of Upper Devonian dolomite, clay, silt and sandstone. The bedrock surface reaches $78 \mathrm{~m}$ a.s.l. According to geological mapping data (Juškevics and Skrebels 2003), the thickness of the Pleistocene deposits ranges from 40 to $60 \mathrm{~m}$, thinning in the direction of the lower levels of the kame 
terrace. Mainly poorly- and medium-sorted Late Weichselian sand and gravel with pebbles, up to $30 \mathrm{~m}$ thick, constitute the upper part of the Pleistocene sequence. Due to this composition, it was formerly speculated that the glacial topography of this locality consisted of typical kames (Mironov 1973). Later Straume (1979) and Straume et al. (1981) classified and mapped this glaciofluvial moulding as a kame terrace with a widespread occurrence of kettles. The results of recent investigations (Dauškans 2013) support the latter interpretation.

The kame terrace segment between the villages of Vietalva and Veckalsnava, known also as Jāņkalns kame terrace (Straume 1979) or Veckalsnava kame terrace (Dauškans 2013), forms the distal and wider part of the Cesvaine-Veseta kame terrace. The Jānukalns terrace is $5.4 \mathrm{~km}$ wide and about $10 \mathrm{~km}$ long. The glaciokarst kettles are mainly concentrated in the downglacier portion of the Jannukalns terrace (Fig. 8.1). Here the absolute height of the kame terrace treads vary from approx. 105-110 $\mathrm{m}$ up to 145-150.1 $\mathrm{m}$ a.s.l., and the highest part of this terrace segment rises up to $60-70 \mathrm{~m}$ above the surrounding plains of the East-Latvian Lowland (Dauškans 2013).

The Cesvaine-Veseta kame terrace itself runs in an ENE-WSW direction alongside the south-eastern slope of the Vidzeme Upland (Straume 1979; Dauškans 2013). It is the biggest kame terrace in Latvia. This terrace extends between the town of Cesvaine and the village of Vietalva, over a distance of $40 \mathrm{~km}$. The Madona-Trepe push moraine (Āboltiņš 1989; Zelčs et al. 2011), which marks the position of the Lubāna lobe terminus during the Gulbene (Middle Lithuanian) deglaciation phase, splits the kame terrace into two separate stretches. The Sauleskalns-Vietalva stretch was formed alongside the Lubāna lobe during the Kaldabruna (South Lithuanian) deglaciation phase, whereas the Cesvaine-Madona stretch was built up by lateral meltwater activity in the course of the Gulbene (Middle Lithuania) deglaciation phase (Zelčs and Markots 2004; Dauškans 2013). Several kame terrace levels which have been detected alongside the terrace show a well-expressed surface sloping in a downglacier direction and towards the Lubāns lobe. In addition to the glaciokarst kettle features the kame terrace has also been eroded by meltwater streams and deeply incised valleys of small rivers flowing from the neighbouring Vidzeme Upland area. Moreover, the highest upstream levels at 145-160 $\mathrm{m}$ a.s.l. between the towns of Cesvaine and Madona, which resemble kame terrace treads and abut risers, probably represent beds of the lateral drainage valleys, because of the occurrence of high concentrations of boulders or boulder pavements on the tops as a result of removal of finer particles of glacial deposits, supposedly till, by meltwater flow streams (Zelčs et al. 2011).

During the fieldwork several glaciokarst kettles were inspected within the Jāṇkalns kame terrace segment. After assessment of their morphology, the most impressive kettle hole was selected for further studies (see Fig. 8.1 for location). This glaciokarst kettle hole was surveyed with a Nikon NPL-332 total station, using reference points obtained with a Magellan ProMark3 post-processing GPS system and data from the reference station service provider LatPOS. The elevation above mean sea level has been calculated using the LV'98 geoid model. The topographical survey plan was drafted using $Q G I S$ software, whereas the digital elevation model (DEM) was generated using the kriging interpolation method of the $S A G A$ GIS software.

During studies of the internal composition of the glaciokarst kettles we encountered difficulties, the most significant of which was the lack of outcrops in kettles. Accordingly, in further studies we had to use other methods, such as ground penetrating radar (GPR) profiling. GPR profiling was carried out with a Zond 12-e GPR manufactured by SIA Radar Systems, using a common offset configuration. In the course of research two antenna systems were used: $75 \mathrm{MHz}$ and $300 \mathrm{MHz}$. The GPR profiles were processed and analysed with the Prism 
2.5 software. Unfortunately, the direct electromagnetic wave propagation speed in the sediments using common midpoint or a similar method was not determined. Therefore, the depth that the identified signals had been received from was calculated using the theoretical dielectric permittivity values for dry sand $(\varepsilon=6)$ (Neal 2004). The geological structure of the selected glaciokarst kettle and surrounding area was inspected using a hand drill.

Altogether, five GPR profiles that cross or reach the bottom of the glaciokarst kettle were obtained. Five boreholes were made along GPR profile I-II. The spatial location of the GPR profile lines and boreholes was recorded with the total station to combine GPR profiles with DEM and borehole data. A topographic model of the glaciokarst kettle and the spatial location of GPR profiles is shown in Fig. 8.2.

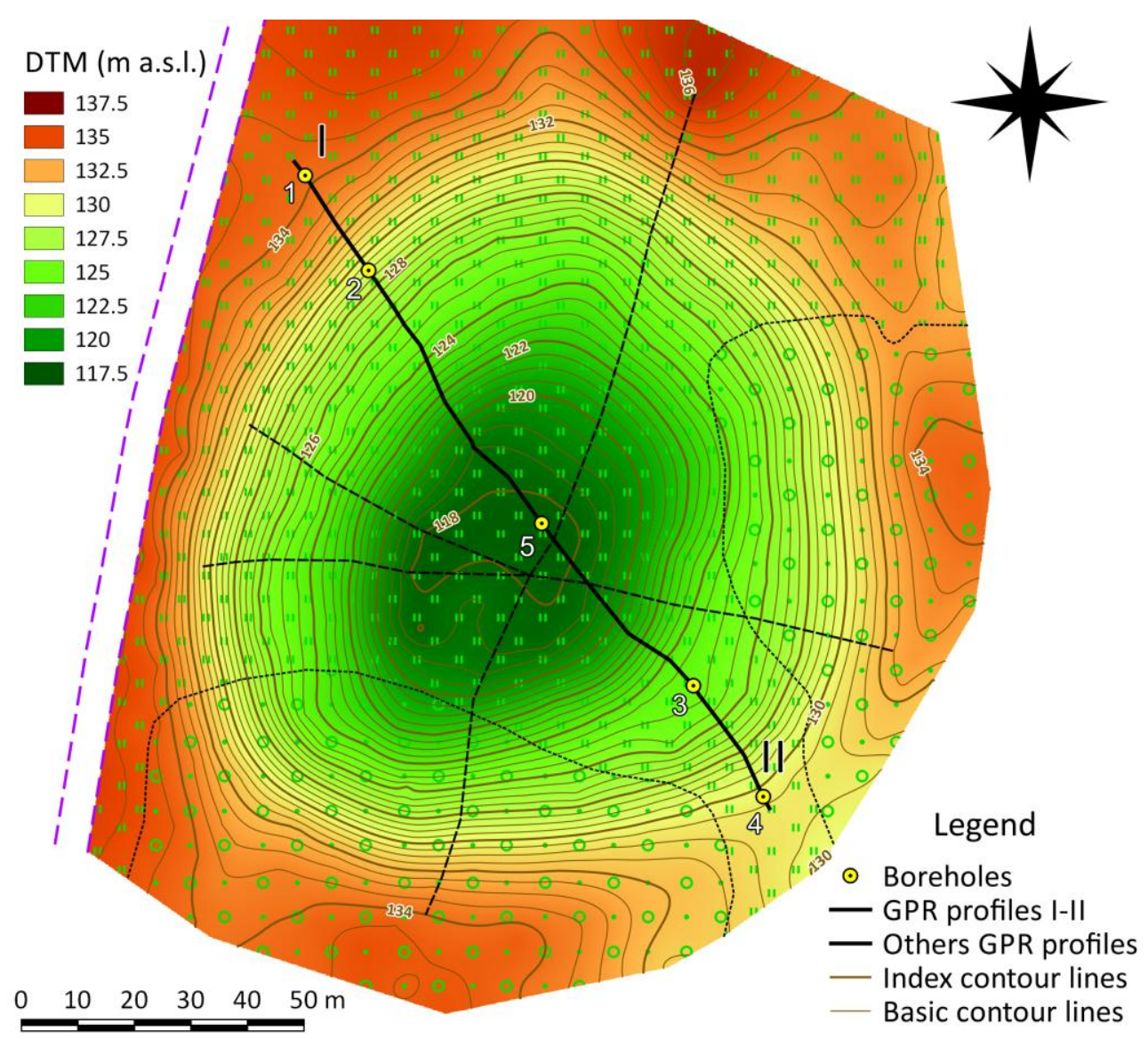

Fig. 8.2. DEM of the glaciokarst kettle hole with respect to the spatial location of GPR profiles.

In the research area high-quality geophysical data were obtained that provides indirect information on the geological structure of the research area. During GPR data processing and analysis it was recognised that the GPR profiles obtained with the $300 \mathrm{MHz}$ antenna system contain more information about the geological structure of the research area. It is probable that good-quality data were not obtained from GPR profiling using the $75 \mathrm{MHz}$ antenna system because the presence of vegetation meant that it was necessary to keep the antenna system relatively high above ground surface. On the other hand, the GPR profiles obtained using the $300 \mathrm{MHz}$ antenna system provided detailed information about the geological structure of the research area approximately to $10 \mathrm{~m}$ depth. Several informative signals where identified in the GPR profiles, which are connected with boundaries of sediment layers having different electromagnetic properties (Fig. 8.3A). 
From the GPR profiles several step-like features in the side walls of the glaciokarst kettle were identified. In the central part of the kettle hole subhorizontally bedded sediments were identified (Fig. 8.3B).
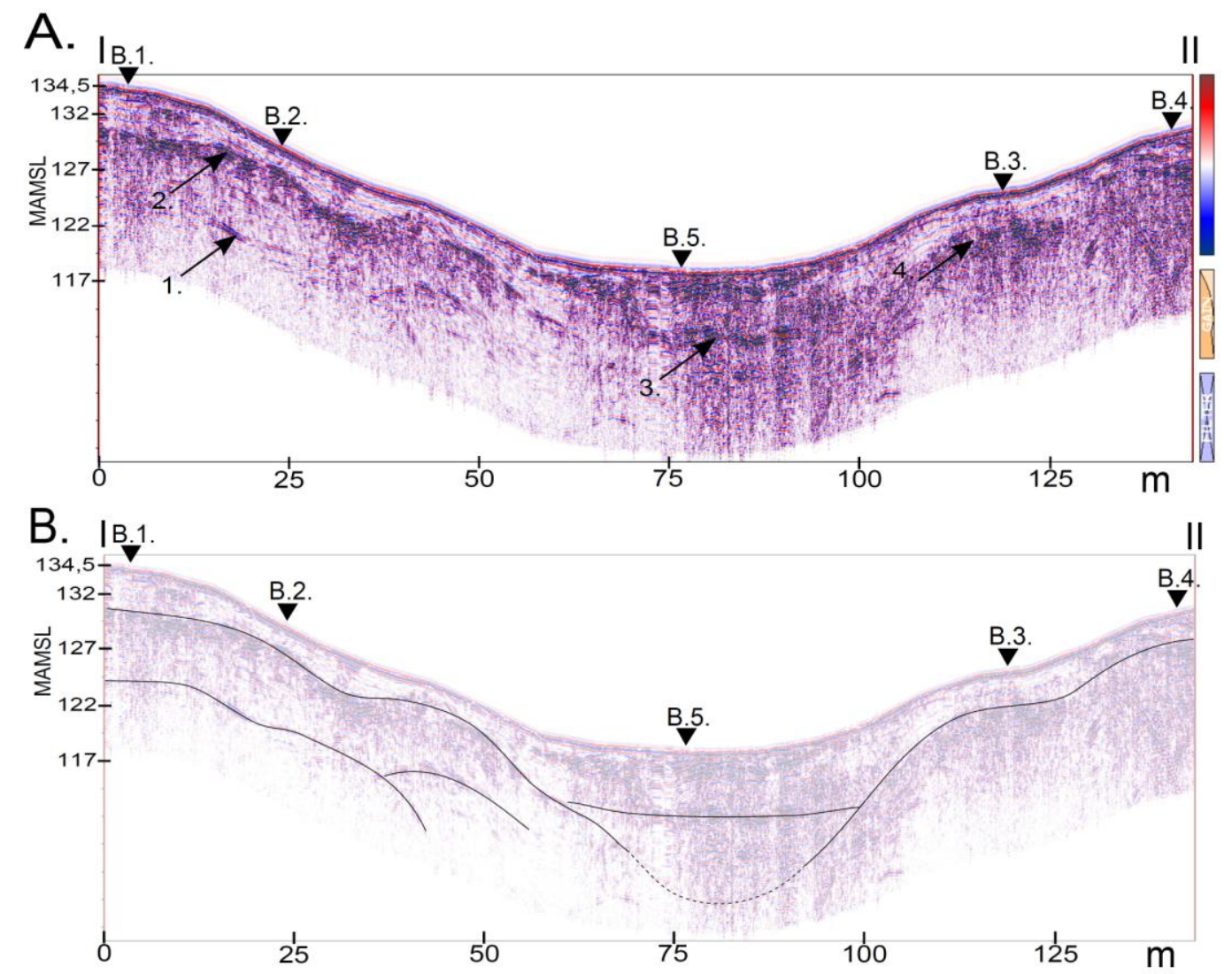

Fig. 8.3. GPR profile showing identified informative signals (A) and reconstructed internal structure of glaciokarst kettle (B). Legend: black arrows denote identified GPR signals related to boundaries of sediment layers; black triangles show coring sites; black dashed lines indicate possible continuation of identified boundaries.

The boreholes reached a maximum depth of about $4.5 \mathrm{~m}$. In all boreholes well-sorted, fine-grained and coarse-grained sand was recorded. Overall it was ascertained that with increasing depth the average grain size of the sediments increases from silty sand at the ground surface to coarse-grained sand with fine gravel at a depth of approximately $4 \mathrm{~m}$. It was also found that the moisture content gradually increases with depth, although the groundwater surface was not reached anywhere.

The information obtained from the boreholes made in the side walls of the glaciokarst kettle concerning the sediment layers in the research area shows that there are no abrupt changes in granulometric distribution of sediments. As a result, the GPR signals cannot be securely related to identified boundaries of sediment layers. On the other hand, in the central part of the glaciokarst kettle, in borehole 5, glaciolacustrine sediments were identified and also the GPR data clearly shows that in the central part of the glaciokarst kettle the sediment layers have distinct horizontal bedding.

To sum up, it should be emphasized that the Jānukalns kame terrace segment was located somewhat upglacier from the terminal coalescence zone of the Lubāns lobe and the Zemgale lobe (Zelčs and Markots 2004). This zone existed during the last glacier decay, up to the Kaldabruña (South Lithuanian) deglaciation phase (Zelčs et al. 2011). Evidently such a position greatly facilitated glacier fracturing and formation of buried or partially buried blocks 
of ice, as well as initially also accelerated melting. The geological structure, particularly the thick cover of the permeable kame terrace sediments and the location, next to the deeply incised valley of the River Veseta, prevented the formation of kettle lakes and paludification.

\section{References}

Āboltinš, O. P. 1989. Glyatsiostruktura i lednikovy morfogenez [Glaciotectonic structure and glacial morphogenesis]. Rīga: Zinātne, 284 pp. (In Russian).

Dauškans, M. 2013. Kèmu terases Austrumlatvijas augstienēs [Kame terraces in the eastern Latvian uplands]. LU Akadēmiskais apgāds, Rīga, 126 pp.

Juškevičs, V., Skrebels, J. 2003. Quaternary deposits. In: Āboltiňš, O., Brangulis, A.J. (eds.), Geological Map of Latvia. Scale 1:200,000. Sheet 34-Jēkabpils. Sheet 24-Daugavpils. Explanatory Text and Maps. State Geological Survey, Rīga, pp. 10-29.

Mironov, G.I. 1973. Karta chetvertichnykh otlozheniy masshaba 1:200000 Pribaltiyskaya seriya, 0-35-XXVI (Cesis) [Map of Quaternary deposits at scale 1:200,000. Baltic region series, 0-35-XXVI (Cesis)]. Aerologiya, Moskva.

Neal, A. 2004. Ground-penetrating radar and its use in sedimentology: principles, problems and progress. EarthScience Reviews, 66, 261-330.

Straume, J. 1979. Geomorphology. In: Misans, J., Brangulis, A., Danilans, I., Kuršs, V. (eds), Geologicheskoe stroyenie i poleznye iskopayemye Latvii, p. 302-345. Riga: Zinatne (in Russian).

Straume, J., Juškevičs, V., Meirons, Z. 1981. Latvijas PSR geomorfologiskā karte. Mērogs 1:500000 [Geomprhological map of Latvian SSR. Scale 1:500,000]. VSEGEI L̦eningradas kartogrāfijas fabrika.

Zelčs, V., Markots, A. 2004. Deglaciation history of Latvia. In: Ehlers, J., Gibbard, P. L. (eds.), Quaternary Glaciations - Extent and Chronology. Part I: Europe. Developments in Quaternary Science, 2. Elsevier, Amsterdam, pp. 225-243.

Zelčs, V., Markots, A., Nartišs, M., Saks, T. 2011. Chapter 18: Pleistocene Glaciations in Latvia. In: Ehlers, J., Gibbard, P.L., Hughes, P.D. (eds.), Quaternary glaciations - extent and chronology. A closer look. Developments in Quaternary Science, 15. Elsevier, pp. 221-229. 


\title{
STOP 9: Upper Daugava spillway valley and associated gully network at Vasargelišķi
}

\author{
Juris Soms ${ }^{\mathrm{a}}$ and Vitālijs Zelčs ${ }^{\mathrm{b}}$ \\ ${ }^{a}$ Daugavpils University, Latvia \\ ${ }^{\mathrm{b}}$ University of Latvia, Latvia
}

The stop site at the Vasargelišķi village $\left(55^{\circ} 54^{\prime} 56^{\prime \prime} \mathrm{N}, 26^{\circ} 49^{\prime} 05^{\prime \prime} \mathrm{E}\right)$ is located about 6 $\mathrm{km}$ east of Daugavpils, within the Upper Daugava spillway valley.

The Upper Daugava spillway valley is one of the oldest and largest in Latvia. It stretches for a distance of $50 \mathrm{~km}$ between Krāslava town and Krauja village (Fig. 9.1). The spillway valley was carved in the lowermost part of the Upper Daugava depression through the icemarginal belts of the Dagda and Kaldabruna phases. It was formed as a result of the interplay between meltwater discharge from the Polatsk and Nīcgale proglacial lakes. The Upper Daugava spillway separates the Latgale Upland from the Augšzeme Upland.

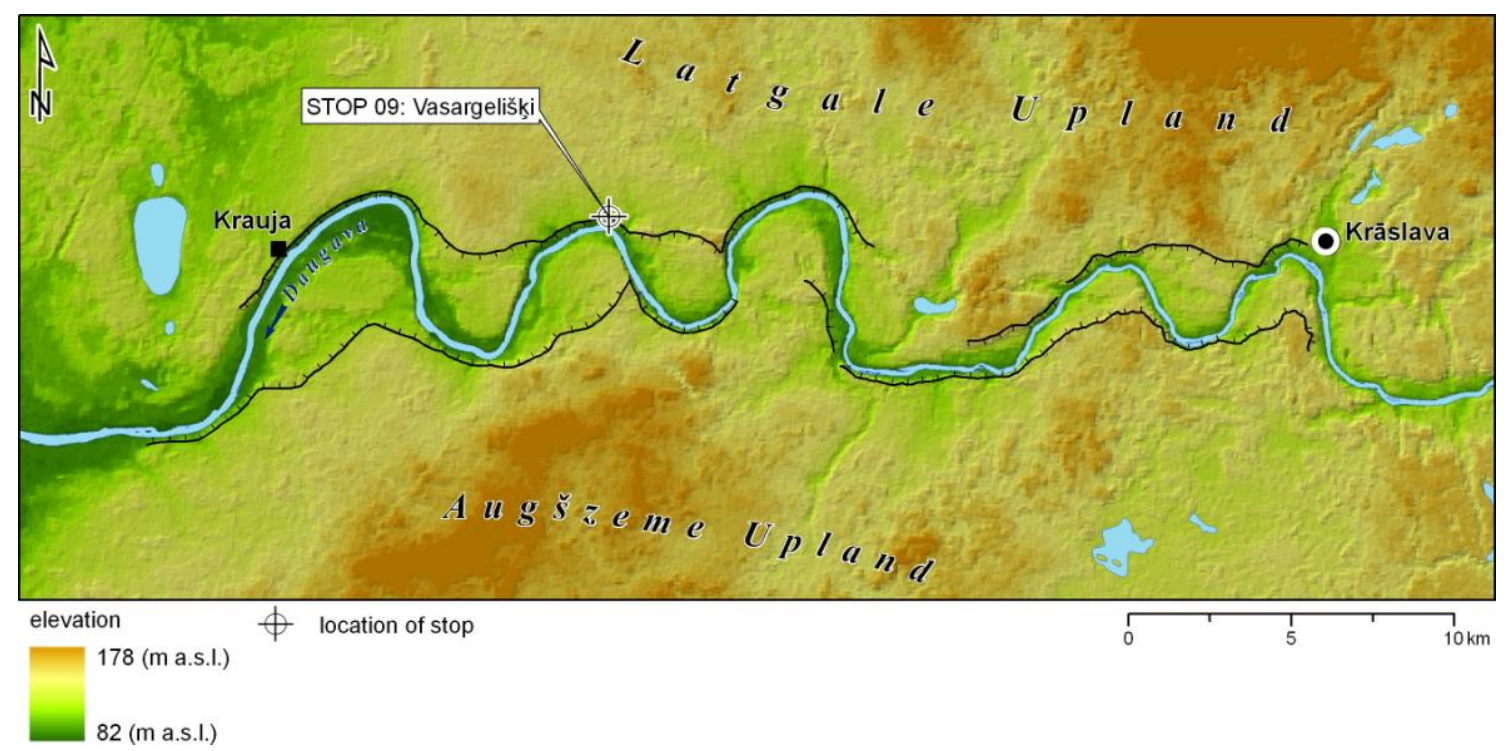

Fig. 9.1. Digital elevation model of the Upper Daugava spillway valley and surroundings.

Nowadays the spillway valley is maintained by the River Daugava in its course from the Polatsk Lowland in the east to the East-Latvian Lowland in the west. In this stretch the River Daugava valley is terraced. The cross-profile of the valley is asymmetric, with mainly erosional terraces (Eberhards 1972). Only the first (I) or youngest terrace in this stretch of the Daugava River valley is aggradational (ibid.). Two floodplain levels occur in the valley floor. Entrenched meandering of the river flow is characterized by a relatively high stream gradient of $0.16 \mathrm{~m} \mathrm{~km}^{-1}$. The valley in this stretch is up to $45 \mathrm{~m}$ deep and its width varies from 0.5 to $1.2 \mathrm{~km}$; gentle slopes along the convex banks of terraces alternate with very steep slopes along the undercut concave banks of the meander bands. Analysis of historical maps indicates that the configuration of the river channel is rather stable; the calculated mean rate of lateral erosion is $0.45 \mathrm{~m} \mathrm{y}^{-1}$.

The local relief and geology of the area were largely formed by glacial processes during Pleistocene glaciations, particularly by the last Weichselian event (Zelčs and Markots 2004; Zelčs et al. 2011). However, the valley of the River Daugava as a geomorphological feature differs from the rest of the landforms in this region because it is a proglacial spillway initially formed by ice sheet meltwater streams during the Late Pleistocene and subsequently modified by fluvial processes in the Holocene (Eberhards 1972; Āboltiņš 1994). 
The geological structure of the territory is rather complex both in horizontal and vertical sections. The bedrock surface is represented mainly by poorly-cemented sandstone of Upper Devonian origin and is uneven due to the presence of some fragments of buried preQuaternary valleys (Eberhards 1972). The hypsometric position of the sub-Quaternary surface ranges from $80 \mathrm{~m}$ to $90 \mathrm{~m}$ (Juškevičs and Skrebels 2003). Thereby, considering the presentday local altitudes, along the flanks of the spillway valley the bedrock is capped by relatively thick, up 40-50 m on average, Quaternary cover, whereas at the bottom of the spillway valley the Upper Devonian bedrock is exposed or covered by thin drift in many places.

The vertical cross-section of the Quaternary strata consists of glacial and glacioaquatic deposits formed by several Pleistocene glaciations. The spatial geological structure of the study area surface is characterized by an alternation of boulder sandy and clayey diamicton, basal till deposits or glaciolacustrine clay and silt deposits of the last glaciation; these are sporadically covered by younger Holocene deposits (Juškevičs and Skrebels 2003). It follows that the low hypsometric position of the bedrock and the thickness of the covering Quaternary strata determine that the deposits lying at the surface and exposed to exogenic geological processes mainly consist of erodible Late Pleistocene glacial, glaciofluvial and glaciolacustrine sediments.

Despite the fact that studies focused on the morphology and development of the spillway valley have been conducted since the 1930s (Sleinis 1936), these matters are still under discussion. According to data given in scientific publications, the number of terraces identified by different authors in the spillway valley varies greatly. Thus, Majore (1962) observed five terraces, whereas Eberhards (1972) distinguished eight terraces. The terraces have developed during several phases of incision related to the evolution of the Polatsk and Nicgale ice dammed glacial lakes and associated formation of glacial meltwater outbursts during the Younger Dryas-Allerød (Eberhards 1972). Field surveys performed during the last years with the application of high-precision GPS and GIS techniques indicate that only the 1st and 2nd terraces are easily recognizable, whereas the upper terraces do not have explicit edges and are encountered only in some short stretches of the valley. In addition, the process of identification of terraces is more complicated due to the glaciokarst kettles on their surfaces. These kettles are present as semi-circular, slightly elongated funnel-like closed depressions, which form groups, constituting an undulating belt in planar view (Fig. 9.2).

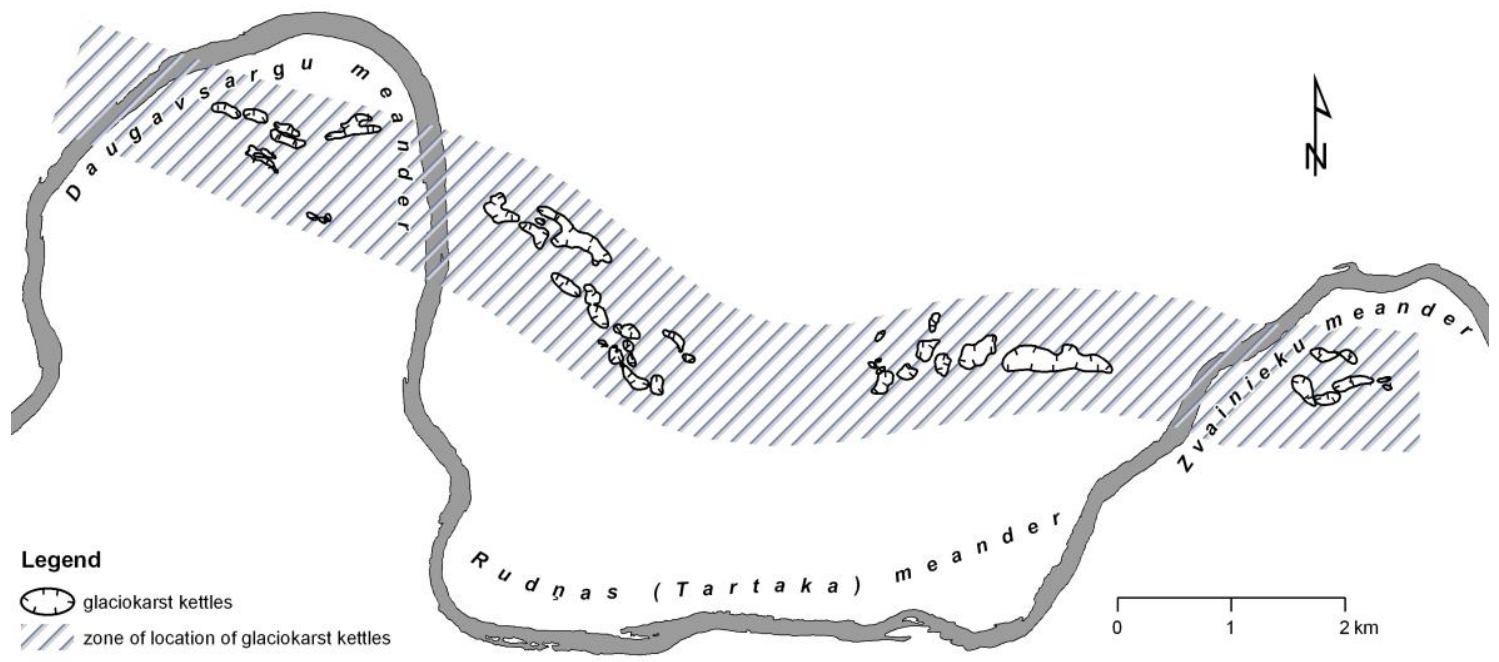

Fig. 9.2. Geographical distribution of glaciokarst kettles within the middle part of the Upper Daugava spillway valley.

In some of these kettles small raised bogs have formed. This made it possible to obtain a core from the bottom part of a peat layer in one of the glaciokarst kettles, in the interval 8.5$6.35 \mathrm{~m}$, for $\mathrm{AMS}{ }^{14} \mathrm{C}$ dating. In order to construct a timescale, three samples from depths of 
$8.20 \mathrm{~m}, 7.35 \mathrm{~m}$ and 6.35 below the surface were dated by $\mathrm{AMS}{ }^{14} \mathrm{C}$ at the Poznan Radiocarbon Laboratory. These dates were calibrated at the one- $\delta$ confidence level using the online version of the OxCal v.4.2 software. (Bronk Ramsey and Lee 2013) and the IntCall3 calibration curve (Reimer et al. 2013). The plant macrofossil fragments collected from the peat samples yielded AMS radiocarbon ages of 10,704 $\pm 50 \mathrm{cal} \mathrm{yr} \mathrm{BP,} 8510 \pm 40 \mathrm{cal} \mathrm{yr}$ BP and $7935 \pm 35$ cal yr BP, respectively (unpublished data).

Fluvial forms created by gully erosion are also characteristic features of the spillway valley (Fig. 9.3). There are more than 350 permanent gullies differing in size and morphology dissecting the main valley sides along the 50-km-long stretch from Krāslava down to Krauja. Total gully length per unit area in some places reaches $4.2 \mathrm{~km} \mathrm{~km}^{-2}$ (Soms 2006). Local altitudes range between c. $90 \mathrm{~m}$ a.s.1 at the valley bottom and $150-170 \mathrm{~m}$ a.s.l in the adjoining hummocky and undulating areas typical of the uplands of Latvia. This also determines the considerable average difference in local relief, which is about $25-45 \mathrm{~m}$, as well as the high position of headwater catchments above the local base level.

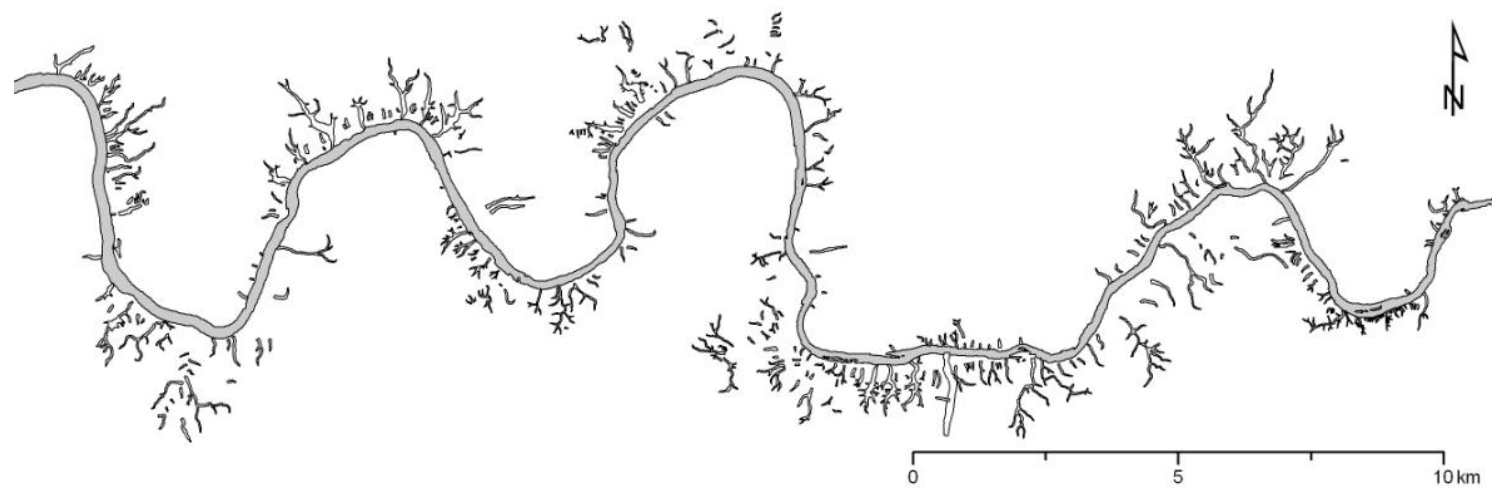

Fig. 9.3. Geographical distribution of gullies within the Upper Daugava spillway valley.

Comparison of the gully network pattern with 'classic' examples reveals its correspondence to the most commonly encountered network type, i.e. a dendritic pattern. The results of geomorphological field studies show that within the spillway valley all morphogenetic types of gullies are represented, i.e. typical gullies, slope gullies, landslide cirque gullies, valley-like gullies and hanging gullies.

The dominant type of landform of linear erosion in the Upper Daugava spillway valley is the typical gully, characterised by considerable dimensions and hydrological connectivity. This type of erosional landform, considering the shape of the gully cross-profile and the stage of development, can be subdivided more specifically into three subtypes: U-shaped or flatbottomed old gullies, $\mathrm{U}+\mathrm{V}$-shaped gullies or gullies of complex origin, and $\mathrm{V}$-shaped gullies. The first, U-shaped or flat-bottomed subtype of the typical gullies, is represented by the largest fluvial erosion landforms among those draining headwater catchments. These geomorphological features, known by the local name sengravas, look similar to small dry grassed valleys and are equivalent to the East European balkas. These flat-bottomed old lateglacial gullies are characterised by impressive morphology, i.e. they are up to $15 \mathrm{~m}$ deep, up to $80 \mathrm{~m}$ wide and up to $2.0 \mathrm{~km}$ long or sometimes even longer, with a typical U-shaped or trapezoidal cross-sectional profile.

The ${ }^{14} \mathrm{C}$ dates and pollen analysis (Soms and Kalnina 2011) reveal that the development of old gullies in the Upper Daugava spillway valley took place before the beginning of intensive agricultural activities and their infilling dates to the Subatlantic ca. 2000 years ago. This also corresponds to the empirically estimated mean annual rates of colluvium deposition, i.e. $0.0011 \mathrm{~m} \mathrm{y}^{-1}$ (Soms and Kalnina 2011). Modelling of paleohydrological conditions by 
approximation of the peak flow discharges $(Q)$ causing gully incision of a given width $(W)$, in its turn, indicates that discharge with values exceeding $48 \mathrm{~m} \mathrm{~s}^{-3}$, which is sufficient for eroding gullies more than $10 \mathrm{~m}$ wide, is virtually impossible under persistent vegetation cover and Holocene climatic conditions in the south-eastern part of Latvia. In this case, development of the largest gullies could be associated with the phase of intensive erosion caused by ice meltwater streams in the Late Pleistocene, at the end of the Late Weischelian glaciation.

The assumption that the old gullies characterised by large dimensions could be periglacial features is consistent with the opinion reported by other researchers who have documented morphologically similar landforms in Western Europe (Langohr and Sanders 1985), in the northeastern part of Poland (Smolska 2007) and the central part of Russia (Panin et al. 2009).

The complex vertical geological structure of this territory and its hydrogeological peculiarities, as well as the fact that the valley acts as the main local zone of groundwater outflow from both confined and unconfined aquifers due to its considerable depth, is behind the formation of a large number of springs here and, as a result, the development of landslide cirque gullies and valley-like gullies. In addition, hanging gullies were formed in the course of the paleogeographic development of the Daugava valley.

\section{References}

Āboltiņš, O. 1994. Augšdaugavas pazeminājums. In: Kavacs, G. (ed-in-chief.), Latvijas daba, 1. Latvijas Enciklopēdija, Rīga, pp. 86-87.

Bronk Ramsey, C., Lee, S. 2013. Recent and planned developments of the program OxCal. Radiocarbon, 55(2-3), 720-730.

Eberhards, G. 1972. Stroyeniye i razvitiye dolin basseyna peki Daugava [Structure and development of valleys of the Daugava river basin]. Zinātne, Rīga, 131 pp. (In Russian).

Juškevičs, V., Skrebels, J. 2003. Quaternary deposits. In: Āboltinš̌, O., Brangulis, A.J. (eds.), Geological Map of Latvia. Scale 1:200,000. Sheet 34-Jēkabpils. Sheet 24-Daugavpils. Explanatory Text and Maps. State Geological Survey, Rīga, pp. 10-29.

Langohr, R., Sanders, J. 1985. The Belgium Loess belt in the last 20,000 years: evolution of soils and relief in the Zonien Forest. In: Boardman, J. (ed.), Soils and Quaternary Landscape Evolution. John Wiley \& Sons, Chichester, pp. 359-371.

Majore, M. 1962. Daugavas ielejas attīstība. Latvijas valsts izdevniecība, Rīga, 77 pp.

Panin, A.V., Fuzeina, J.N., Belyaev, V.R. 2009. Long-term development of Holocene and Pleistocene gullies in the Protva River basin, Central Russia. Geomorphology, 108(1-2), 71-91.

Reimer, P.J., Bard, E., Bayliss, A., Warren Beck, J., Blackwell, P.G., Bronk Ramsey, C., Buck, C.E., Cheng, H., Edwards, R.L., Friedrich, M., Grootes, P.M., Guilderson, T.P., Haflidason, H., Hajdas, I., Hatte, C., Heaton, T.J., Hoffmann, D.L., Hogg, A.G., Hughen, K.A., Kaiser, K.F., Kromer, B., Manning, S.W., Niu, M., Reimer, R.W., Richards, D.A., Scott, E.M., Southon, J.R., Staff, R.A., Turney, C.S.M., van der Plicht, J. 2013. Intcal13 and Marine13 radiocarbon age calibration curves 0-50,000 years cal BP. Radiocarbon, 55, 1869-1887.

Sleinis, I. 1936. Latvijas upes. In: Malta, N., Galenieks, P. (eds.), Latvijas zeme, daba un tauta, 1. Valters un Rapa, Rīga, pp. 192-296.

Smolska, E. 2007. Development of gullies and sediment fans in last-glacial areas on the example of the Suwałki Lakeland (NE Poland). Catena, 71(1), 122-131.

Soms, J. 2006. Regularities of gully erosion network development and spatial distribution in south-eastern Latvia. Baltica, 19(2), 72-79.

Soms, J., Kalnina, L. 2011. Studies of morphology and colluvium of old gullies in the Daugava River ancient valley with respect to the determination of erosion landforms age. Acta Universitatis Latviensis Earth and Environmental Sciences, 767, 75-92 (in Latvian, with English summary).

Zelčs, V., Markots, A. 2004. Deglaciation history of Latvia. In: Ehlers, J., Gibbard, P. L. (eds.), Quaternary Glaciations - Extent and Chronology. Part I: Europe. Developments in Quaternary Sciences, 2. Elsevier, Amsterdam, pp. 225-243.

Zelčs, V., Markots, A., Nartišs, M., Saks, T. 2011. Chapter 18: Pleistocene Glaciations in Latvia. In: Ehlers, J., Gibbard, P.L., Hughes, P.D. (eds.), Quaternary glaciations - extent and chronology. A closer look. Developments in Quaternary Sciences, 15. Elsevier, pp. 221-229. 


\title{
STOP 10: Kame terrace in the Upper Daugava depression at Rakuti, near Krāslava
}

\author{
Vitālijs Zelčs ${ }^{\mathrm{a}}$, Juris Soms ${ }^{\mathrm{b}}$ and Edgars Greiškalns ${ }^{\mathrm{b}}$ \\ ${ }^{\mathrm{a}}$ University of Latvia, Latvia \\ b Daugavpils University, Latvia
}

According to the established deglaciation history of Latvia (Āboltiņš et al. 1972; Meirons et al. 1976; Zelčs and Markots 2004; Zelčs et. al. 2011), the Upper Daugava depression and adjacent glacial uplands were the very first areas to become free of the Fennoscandian ice sheet during the last glacial termination, approximately 16-18 ka BP (Raukas et. al. 1995; Rinterknecht et al. 2006). Consequently, these areas are among those in Latvia which have been exposed to proglacial and non-glacial conditions for the longest period of time. Hence, the geomorphological and geological study of these regions allows reconstruction of the processes and environmental conditions of the events occurring at the end of the Late Pleistocene and beginning of the Early Holocene. In such a context, the possibility of studying the uppermost part of the Late Pleistocene sequence in a number of sections at the Rakuti sand and gravel quarry (Fig. 10.1), with various spatial orientations, permits substantial scientific data to be obtained. The main morphological characteristics and preliminary results of lithological studies from three out of seven studied outcrops (see Fig. 10.1B for location) are demonstrated in this stop description. The quarry covers an area of 4.24 ha and lies 132-134 m a.s.l. During the extraction of sand and gravel the layers of clastic Quaternary sediments are exposed to a depth of up to $12 \mathrm{~m}$.

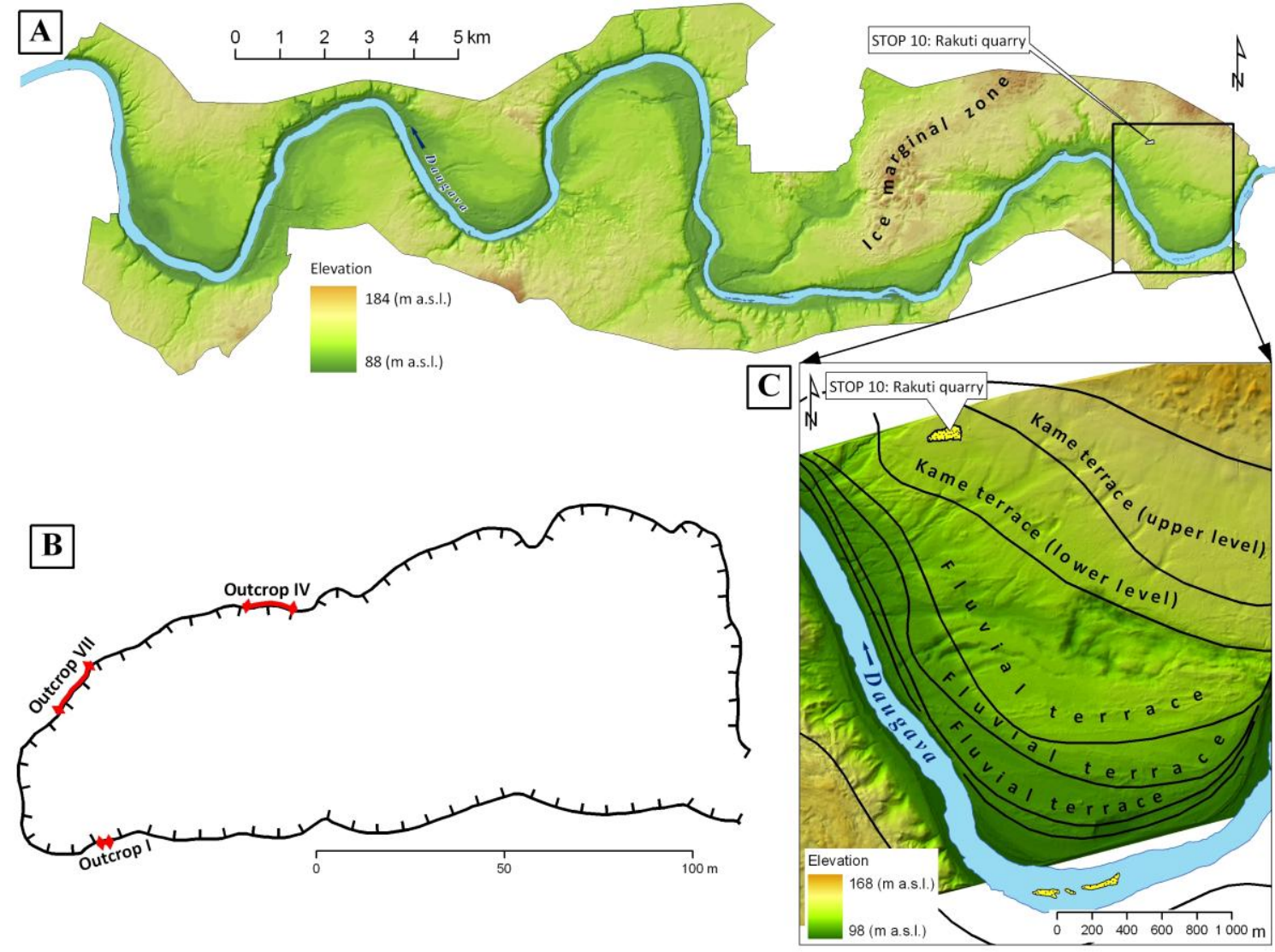

Fig. 10.1. A. Digital elevation model of the Upper Daugava depression and general location of the stop site, distal from the ice-marginal zone. B. Location of the studied outcrops. C. Location of kame and fluvial terraces. 
The Rakuti sand and gravel quarry $\left(55^{\circ} 53^{\prime} 51^{\prime \prime} \mathrm{N}, 27^{\circ} 05^{\prime} 30^{\prime \prime} \mathrm{E}\right)$ is located on a flattopped geomorphic surface complicated by dispersed microforms (e.g. erosional features and small kettle holes) and bounded by the riser of the lowermost terrace, presumed to be fluvial (Fig. 10.1C). Eberhards (1972) has mapped this flat-topped landform, which occurs alongside the northern edge of the Upper Daugava depression, west of the town of Krāslava, as the uppermost terrace or Terrace VIII of the East-Latvian terrace spectrum of the River Daugava. Eberhards (ibid., 2013) and later also Āboltinš (1995) have specified that the terraces (VII to II) were mainly erosional, besides which the terraces of the upper complex (VII-V) were formed by meltwater streams flowing from Lake Polatsk into the Nìcgale ice-dammed lake. However, the course of stream flow during its formation is still an open question, because alongside this terrace the surface slopes slightly to east in the direction of the Polatsk icedammed lake, from 132-134 $\mathrm{m}$ a.s.l. at the quarry down to $128.5 \mathrm{~m}$ a.s.l. for this terrace level, and from $142 \mathrm{~m}$ a.sl. to approximately $138 \mathrm{~m}$ a.s.l. for the uppermost terrace level, over a distance of about $1000 \mathrm{~m}$. Without completely rejecting the idea of meltwater drainage to east, Eberhards (1972) attempted to explain the upstream inclination of the levels of both abovementioned terrace treads, opposite to the modern river flow direction, in terms of glacial isostatic adjustment.

The results of the most recent research lead to a different conclusion and reveal that Terrace VIII is not a fluvial erosional terrace but a kame terrace. The terrace micro-relief and internal structure of the underlying sediments also provide evidence of glaciokarst and periglacial processes, the presence of floating dead ice blocks (Fig. 10.2) and substantial temporal and spatial changes in the depositional environment (Fig. 10.3). These are classic features for identification of kame terraces occurring in various glaciated regions, as noted by Klimek (1956), John (1972), Huddart and Lister (1981), de Jong and Rappol (1983), Bitinas et al. (2004), Pisarska-Jamrozy et al. (2010), and Dauškans (2013).
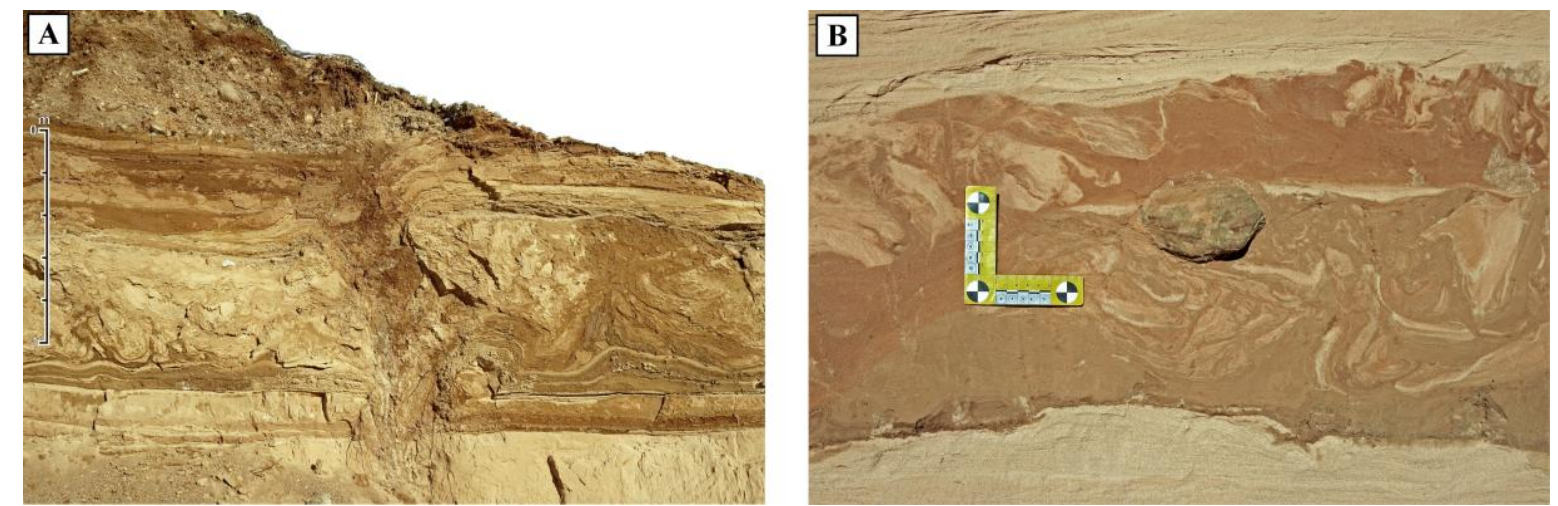

Fig. 10.2. Ice wedge and cryoturbation in horizontally laminated silt and clay interlayered with gravelly sand matrix and occasional cobbles (A) and large dropstone, supposedly, in convoluted and slumped silt and silty sand interlayered with sand (B) in outcrops V and VI located in the NE corner of the Rakuti quarry. Evidently this part was occupied by an ephemeral glaciomarginal lake. The ice wedge and cryoturbation present important evidence of essentially subaerial conditions, which might have been caused by climate deterioration or drainage of this glaciomarginal lake. Besides, occasional carbonate cementation has been observed in the underlying sand. The massively cemented units occur as isolated lenticular patches with a thickness up to $1.5 \mathrm{~m}$.

The kame terrace is located about $20 \mathrm{~km} \mathrm{~W}$ of the highest shoreline (140 m a.s.l.) of the Polatsk ice-dammed lake and $30 \mathrm{~km}$ east of the Nīcgale ice-dammed lake. The Rakuti quarry lies in the proximity of the distal slope of an unnamed ice-marginal zone, considered to be somewhat older than the Kaldabruña ice-marginal position by Meirons et al. (1976), and tentatively assumed to be the Dagda ice marginal zone by Zelčs et al. (2011). According to Zelčs et al. (ibid.), before formation of the Dagda ice marginal features the territory under 
consideration was in the coalescence zone between the Lubāns and Polatsk lobes.

The bedrock surface is on average $85-90 \mathrm{~m}$ a.s.l. In the neighbouring territory on the bottoms of the buried valleys and narrow bedrock depressions it falls to $46 \mathrm{~m}$ b.s.l. The bedrock is Middle Devonian terrigenous sedimentary rock. The thickness of Pleistocene sediments is about 50-60 m, but decreases in the Daugava river valley, reaching $27 \mathrm{~m}$ at Krāslava. The Pleistocene superficial sediments are mapped as Upper Weichselian glaciofluvial gravelly sand (Juškevičs and Skrebels 2003). To the north, in the direction of the Latgale Upland, it is replaced by Late Weichselian till.

Investigation of the internal structure of the sediments underlying the terrace utilised field techniques widely used in Quaternary geology and glacial geomorphology (Hubbard and Glasser 2005), i.e. measurements of long axis orientations of 450 elongate pebbles by identification of their dip and its direction. Simultaneously, 100 pebbles in each of the fractions $8-16 \mathrm{~mm}, 16-32 \mathrm{~mm}$ and $32-64 \mathrm{~mm}$ were collected by dry sieving material from nine layers. Thereafter the three major axes $-\mathrm{a}, \mathrm{b}$ and $\mathrm{c}-$ of each clast were measured by digital callipers and recorded to estimate the shape of pebbles according to the classification of Sneed and Folk (1958). The data were plotted in triangular diagrams using the TriPlot module according to Graham and Midgley (2000).

\section{Outcrop I}

Matrix supported massive diamicton interlayered by boulder diamicton and gravelly sand is underlain by silty sand. In the basal part the silty sand becomes coarser and contains gravel. The lower bed consists of planar cross-stratified fine to medium-grained sand, the structure of which is excellently visible in the sections striking perpendicular to this outcrop.

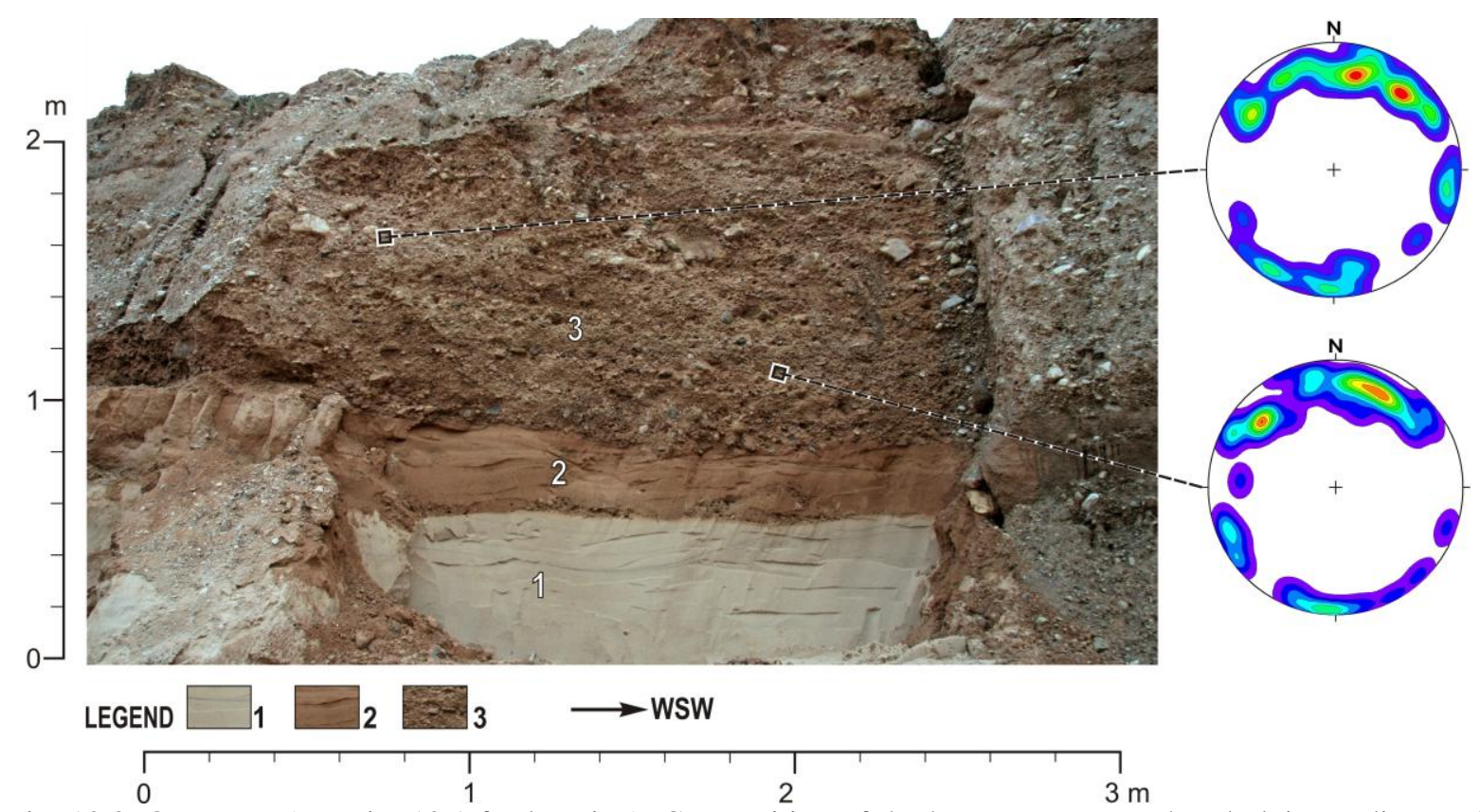

Fig. 10.3. Outcrop I (see Fig. 10.1 for location). Composition of the kame terrace tread underlying sediments is shown in the section subparallel to the terrace stretch. Legend of identified layers: 1 - planar cross-stratified fine to medium-grained sand; 2 - trough cross-stratified silty sand with occasional gravel and gravel lenses in the basal part; 3 - massive, matrix supported clast rich diamicton, interlayered with gravelly sand.

Three-dimensional diagrams of clast orientation are on the lower hemisphere and in equal area projection. Based on 50 elongated clast measurements. Contoured at $0-1-2 \ldots 6-8$ percent areas.

The measurements of the orientation of clasts indicate a relatively weak to moderately strong multimodal azimuth. The dip varies across a wide range. However, it indicates the 
gravity flow direction from the melting stagnant ice lobe to the lateral slope. The diamicton is interpreted as flow till re-deposited by dense cohesive flow, whereas the underlying silty sand with an admixture coarse grained particles has perhaps been deposited as fluidised sediment flow, but its structure has been slightly altered by deformation. The lower sedimentary unit represents a delta foreset series.

\section{Outcrop IV}

The uppermost part of the exposed section is similar to Outcrop I. For instance, unit 7 can be conditionally correlated with unit 1 of outcrop I (Figs. 10.3 and 10.4). Five beds of diamicton lithofacies can be distinguished in the section. Excluding units 7 and 8, the lower boundaries of other diamicton units with horizontally laminated sand and fines are sharp, presumably erosional, but the boundary between units 5 and 4 is also marked by erosional scours (Fig. 10.4). The results of orientation of the elongated clasts mainly show multimodal azimuth patterns. Only in unit 3 and unit 5 clast linearity is quite strong and indicates flow direction at an oblique angle to the stagnant ice.

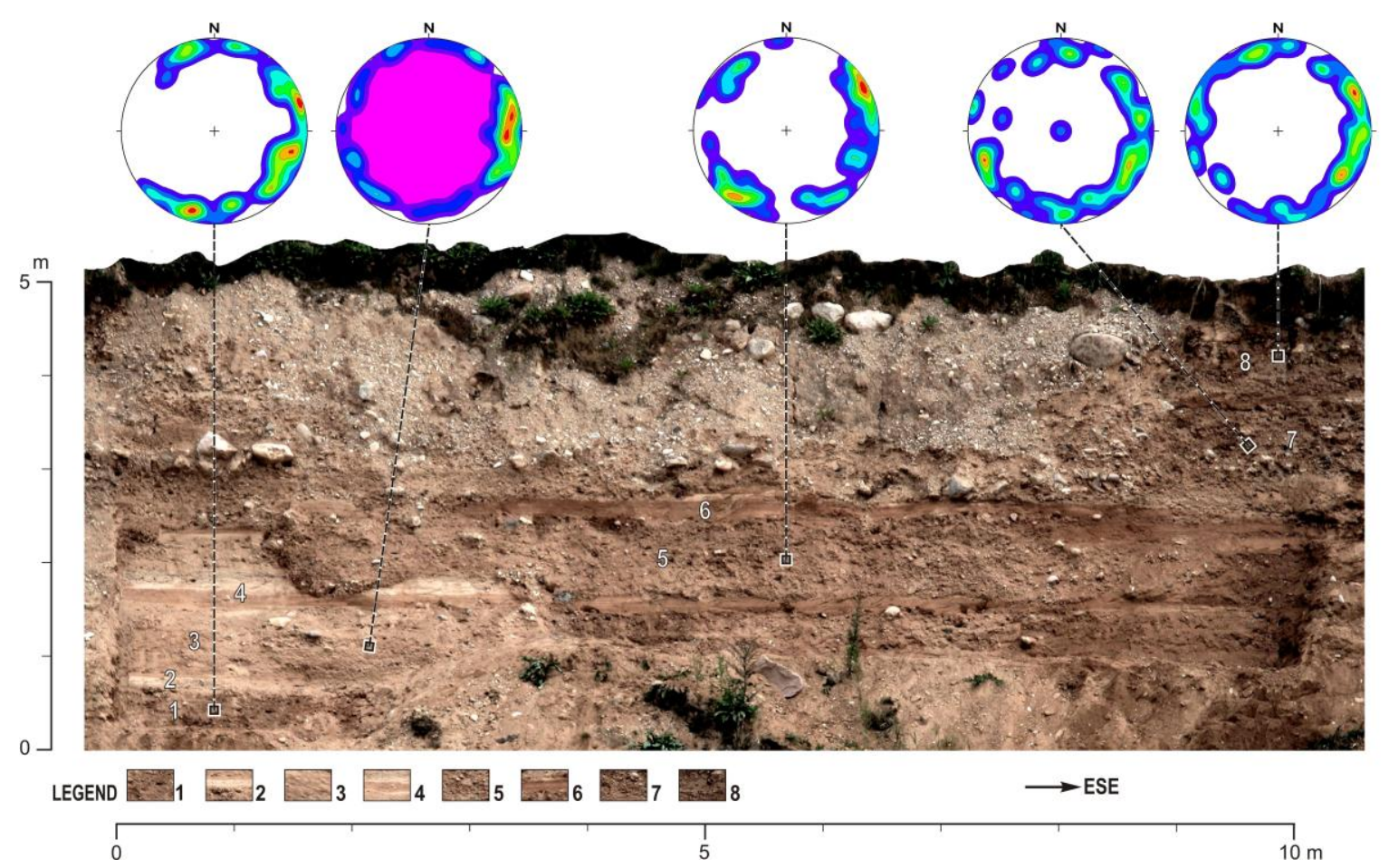

Fig. 10.4. Outcrop IV (see Fig. 10.1 for location). Composition of the sediments underlying the kame terrace tread is shown in the section alongside the terrace stretch. Legend of identified layers: 1 - matrix supported, clast moderate, massive diamicton; 2 - horizontally laminated silty sand; 3 - massive, matrix supported, clast moderate diamicton; 4 - fine sand and sandy silt, horizontally laminated; 5 - massive, matrix supported, clast moderate diamicton; 6 - horizontally laminated fines; 7 - matrix supported, clast rich diamicton with boulder concentration zone; 8 - clast supported diamicton with boulder concentration on the top.

The three-dimensional diagrams of clast orientation are on the lower hemisphere and in equal area projection. Based on 50 elongated clast measurements. Contoured at 0-1-2...6-8 percent areas.

\section{Outcrop VII}

This outcrop is situated at the NW corner of the quarry (Fig. 10.1). It displays an alternation of sedimentary units consisting of coarse clastic and finer material (Fig. 10.5). Some of them can be correlated with units occurring in Outcrop IV. The orientation maxima of the elongated clasts are well-expressed. They indicate a debris flow direction parallel or 
subparallel to the kame terrace stretch.

Analysis of field study data demonstrate that in the western part of the quarry clastic sediments are dominant and mainly consist of poorly sorted gravel with pebbles, and bouldersize material in places, with a sandy loam matrix (Figs. 10.3, 10.4 and 10.5). The coarse clastic material is interlayered with basin sediments, and underlain by planar cross-stratified fine to medium-grained sand in the western part of the quarry. Eastwards this well-sorted sand is replaced by rippled and horizontally laminated sandy silt, evidently deposited in a shallow lake. The role of basin deposition in the topmost part of the sediment sequence also increases in the same direction.

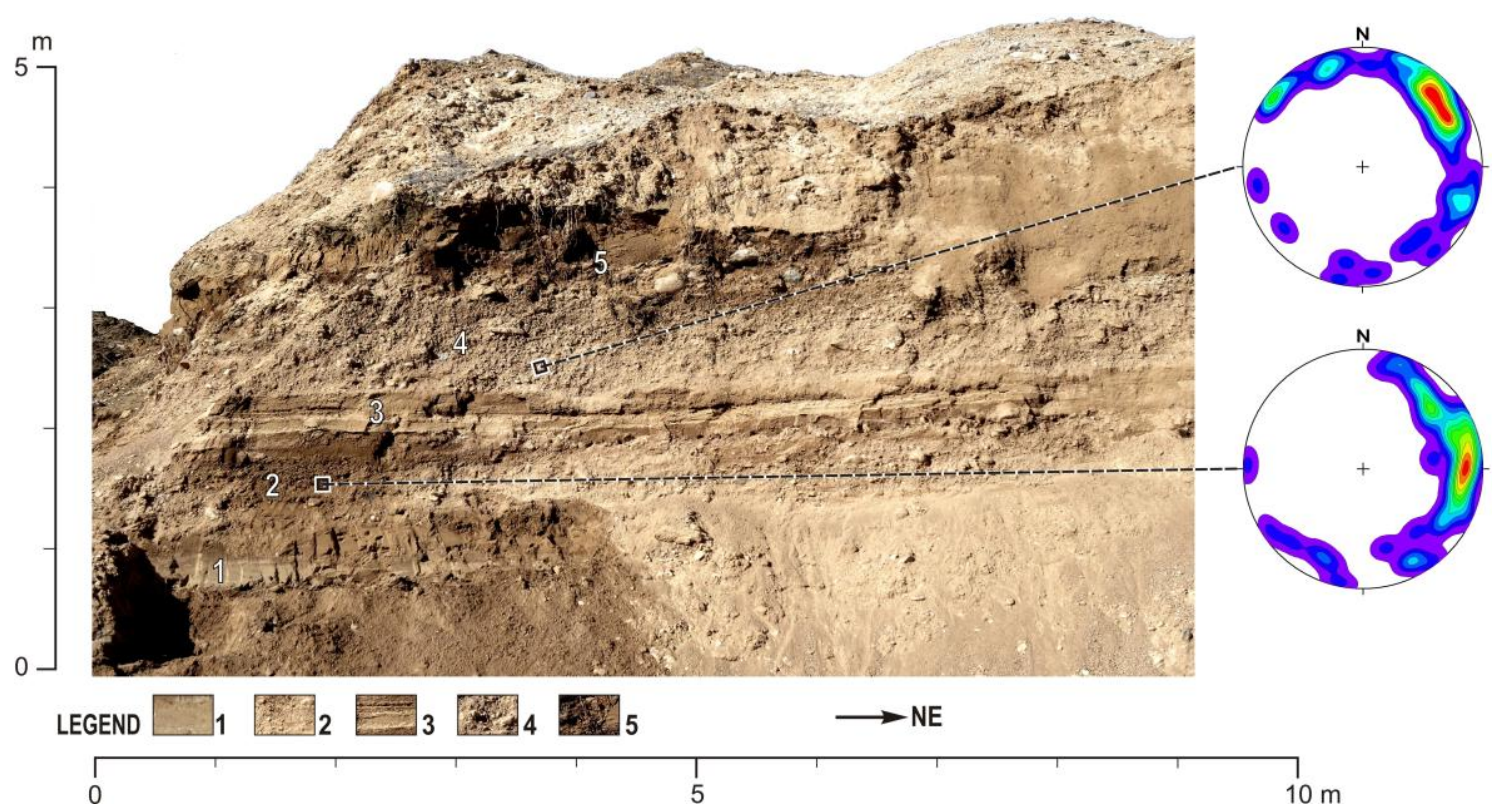

Fig. 10.5. Outcrop IV (see Fig. 10.1 for location). Composition of the sediments underlying the kame terrace tread is shown in the section transverse to the terrace stretch. Legend of identified layers: 1 - horizontally laminated sandy silt (in Fig. 10.4: unit 4); 2 - massive, matrix supported, clast moderate to rich, gravelly diamicton; 3 - horizontally laminated silt and rippled fine sand interlayers; 4 - clast supported diamicton with occasional cobbles and boulder concentration zone (tentatively correlated to unit 7 in Fig. 10.4); 5 - deformed diamicton with admixture of fines and occasional boulders.

Three-dimensional diagrams of clast orientation are on the lower hemisphere and in equal area projection. Based on 50 macrofabric measurements. Contoured at 0-1-2...6-8 percent areas.

Pebble- to boulder-sized clasts are mostly unconsolidated and their roundness varies widely from well-rounded to sub-angular. Clasts of the limestone and dolomite lithological groups dominate in all examined layers of diamicton, the proportion of clasts of carbonate rocks varying from $70 \%$ to $82 \%$ of the total number of pebbles. Estimation of the shape of pebbles according to the Sneed and Folk (1958) classification indicates that compact-bladed and bladed clasts are dominant; however, such a shape is not typical for glacial sediments. In addition, the analysis of data on the ratio of the shortest to longest axis of pebbles, i.e. c/a-axis $\leq 0.4$ (termed the $\mathrm{C}_{40}$ index) according to Graham and Midgley (2000), demonstrates that all values plotted in triangular diagrams are located both above and below the $\mathrm{C}_{40}$ index line, although the values of pebbles of crystalline lithology are located mainly above it. Such a distribution of values in triangular diagrams is not typical for subglacially transported sediments, which are usually characterized by a concentration of points above the $\mathrm{C}_{40}$ line (Graham and Midgley 2000). A feasible explanation of this finding is that pebbles of carbonate lithology reflect a short transport distance of deposited clastic sediments.

In most cases the clast linearity coincides with the stretch of the kame terrace, indicating 
that debris was transported from the ice marginal zone. However, in some cases clasts have been oriented at an oblique angle to the stagnant ice or the lateral slope of the Upper Daugava depression. Such a clast spatial orientation and erosional marks on the lateral slope as well as on the scarp of the upper kame terrace level (Fig. 10.1) suggest that proglacial waters have been produced not only by ice melting but also by extra-glacial waters draining from the already ice-free parts of the Latgale Upland.

It is likely that the kame terraces at Rakuti are located where meltwater flowed between stagnant ice and the lateral slope of the Upper Daugava depression. Deposition from stagnant ice and extraglacial waters, and in an ephemeral glaciomarginal lake has resulted in continuous kame terrace.

\section{References}

Āboltinšs, O. P., Veinbergs, I. G., Stelle, V. J., Eberhards, G. J. 1972. Osnovniye kompleksy marginal'nykh obrazovaniy i otstupaniye lednika na territorii Latviiskoy SSR [Main complexes of marginal formations and glacier retreat in the territory of Latvian SSR]. In: Goretskij, G. I., Pogulajev, D. I., Shick, S. M. (eds.), Krayevye obrazovaniya materikovykh oledeneniy [Marginal formations of continental glaciations]. Nauka, Moskva, pp. 30-37 (in Russian).

Bitinas, A., Karmaziene, D., Jusiene, A. 2004. Glaciolacustrine kame terraces as an indicator of conditions of deglaciation in Lithuania during the Last Glaciation. Sedimentary Geology, 165(3-4), 285-294.

Dauškans, M. 2013. Kēmu terases Austrumlatvijas augstienēs. LU Akadēmiskais apgāds, Rīga, 126 lpp.

Eberhards, G. 1972. Stroyeniye i razvitiye dolin basseyna peki Daugava [Structure and development of valleys of the Daugava river basin]. Zinātne, Rīga, 131 pp. (In Russian)

Eberhards, G. 2013. Upju ieleju veidošanās un mūsdienu gultnes procesi dienvidaustrumu Baltijā. Latvijas Universitāte, Rīga, 211 lpp.

Graham, D.J., Midgley, N.G. 2000. Graphical representation of particle shape using triangular diagrams: an Excel spreadsheet method. Earth Surface Processes and Landforms, 25 (13), 1473-1477.

Hubbard, B., Glasser, N. 2005 Field Techniques in Glaciology and Glacial Geomorphology. John Wiley \& Sons, Chichester, 412 pp.

Huddart, D., Lister, H. 1981. The Origin of Ice Marginal Terraces and Contact Ridges of East Kangerdluarssuk Glacier, SW Greenland. Geografiska Annaler, 63A, 31-39.

John, B.S. 1972. A Late Weichselian Kame Terrace at Mullock Bridge, Pembrokeshire. Proceedings of the Geologists Association, Elsevier Ltd., London, pp. 213-229.

de Jong, M.G.G., Rappol M. 1983. Ice-marginal debris flow deposits in western Allgau,southern east Germany. Boreas, 12, 57-70.

Juškevičs, V., Skrebels, J. 2003. Quaternary deposits. In: Āboltiňš, O., Brangulis, A.J. (eds.), Geological Map of Latvia. Scale 1:200,000. Sheet 34-Jēkabpils. Sheet 24-Daugavpils. Explanatory Text and Maps. State Geological Survey, Rīga, pp. 10-29.

Meirons, Z., Straume, J., Juškevičs, V. 1976. Main varieties of the marginal formations and deglaciation of the Last glaciation in the territory of the Latvian SSR. In Danilāns, I. (ed.), Problems of Quaternary Geology, 9. Rìga, Zinātne, pp. 50-73 (in Russian, with English summary).

Pisarska-Jamrozy, M., Machowiak, K., Krzyszkowski, D. 2010. Sedimentation style of a Pleistocene kame terrace from the Western Sudety Mountains, S Poland. Geologos, 16 (2), 101-110.

Raukas, A., Āboltiņ̌̌, O., Gaigalas, A. 1995. The Baltic states. Overview. In: Shirmer, W. (ed.), Quaternary field trips in Central Europe, 1. München, Verlag Dr. Friedrich Pfeil, pp.146-151.

Rinterknecht V. R., Clark P. U., Raisbeck G. M., Yiou F., Bitinas A., Brook E. J., Marks L., Zelčs V., Lunkka J.P., Pavlovskaya I. E., Piotrowski J. A., Raukas A. 2006. The Last Deglaciation of the Southeastern Sector of the Scandinavian Ice Sheet. Science, 311, 10 March 2006, 1449-1452.

Sneed, E.D., Folk, R.L. 1958. Pebbles in the lower Colorado River, Texas, a study of particle morphogenesis. Journal of Geology, 66 (2), 114-150.

Zelčs, V., Markots, A. 2004. Deglaciation history of Latvia. In: Ehlers, J., Gibbard, P. L. (eds.), Quaternary Glaciations - Extent and Chronology. Part I: Europe. Developments in Quaternary Science, 2. Elsevier, Amsterdam, pp. 225-243.

Zelčs, V., Markots, A., Nartišs, M., Saks, T. 2011. Chapter 18: Pleistocene Glaciations in Latvia. In: Ehlers, J., Gibbard, P.L., Hughes, P.D. (eds.), Quaternary glaciations - extent and chronology. A closer look. Developments in Quaternary Science, 15. Elsevier, pp. 221-229. 


\title{
STOP 11: Recessional moraine ridge at Veresovka, Rāzna glacial depression
}

\author{
Vitālijs Zelčs ${ }^{\mathrm{a}}$, Juris Soms ${ }^{\mathrm{b}}$, Aivars Markots ${ }^{\mathrm{a}}$ and Ivars Strautnieks ${ }^{\mathrm{a}}$ \\ ${ }^{\mathrm{a}}$ University of Latvia, Latvia \\ ${ }^{\mathrm{b}}$ Daugavpils University, Latvia
}

A recessional moraine ridge at Veresovka village stretches for a distance of $0.5 \mathrm{~km}$ along the eastern shore of Lake Rāzna, south of the River Rēzekne outflow (Fig. 11.1). It is located proximally from the Kaldabruna ice-marginal zone, inside a relatively broad glacial depression occupied by the Ràzna glacier tongue during the earliest deglaciation phases of the Latgale Upland, when the Lubāns ice lobe terminated here as a series of glacier tongues (Meirons, 1975; Zelčs and Markots 2004; Zelčs et al. 2011). Interlobate hummocky moraines that terminate on both sides of the glacial depression and trend transverse to the ice-marginal zone are regarded as convergence zones between the Rāzna and Malta tongues in the southwest, and the Rāzna and Cirma tongues in the north-east (Fig. 11.1).

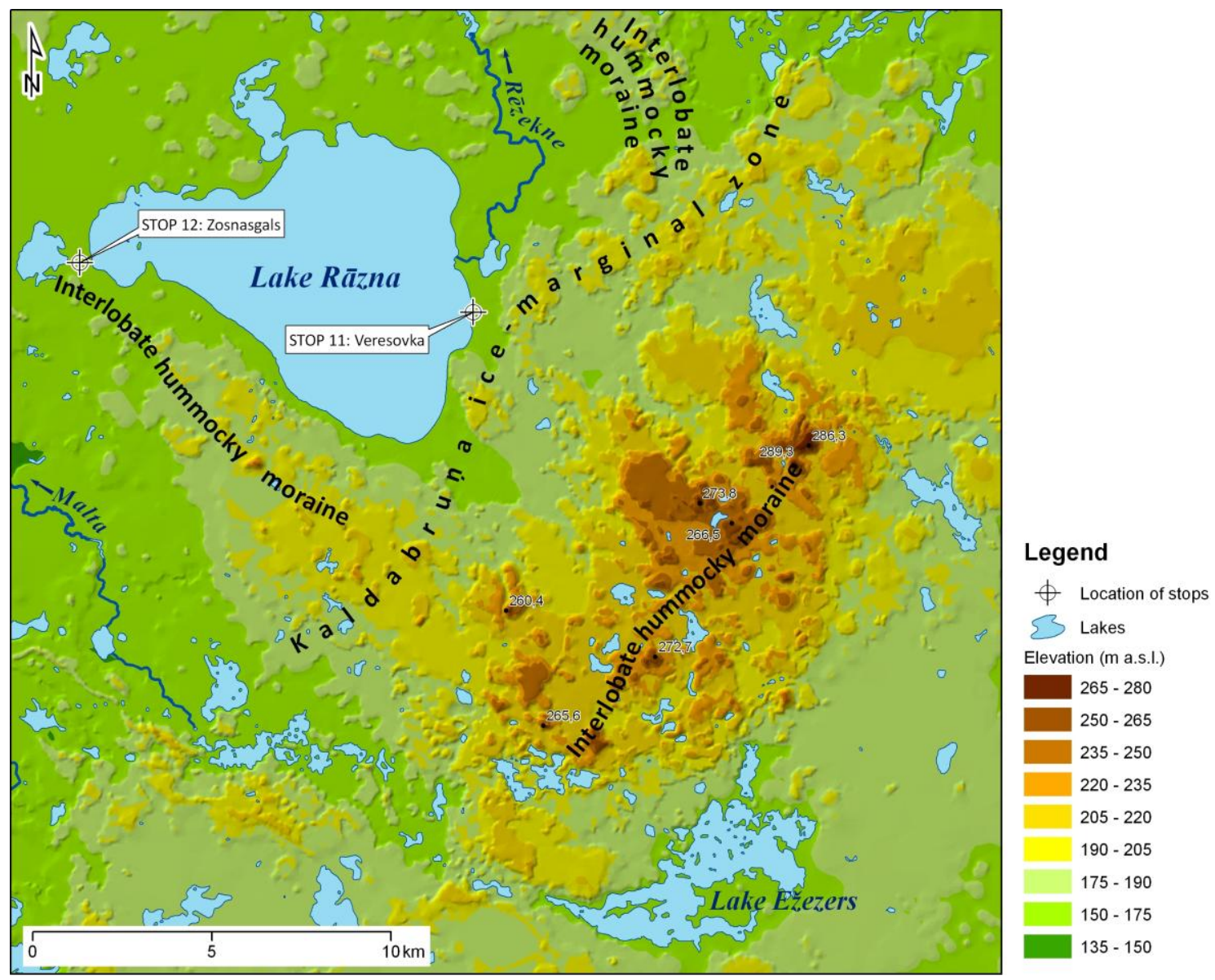

Fig. 11.1. Topography of the surroundings of Lake Rāzna, showing the study area.

The Rāzna glacial depression and the Kaldabruña ice-marginal zone are situated upglacier from the highest part of the Latgale Upland, occupied by an impressive interlobate hummocky moraine ridge rising between the Lubāns and Polatsk ice lobes (Fig.11.1). The moraines formed transversely and are not oriented to the ice flow direction. Streamlined features as well as stagnant ice topography alternate with smoother surfaces of narrow strips of glacial plains, indicating diversity and spatio-temporal superimposition of glacial 
lithomorphogenetic processes in the depression as a result of glaciodynamic changes during the course of thinning of the Rāzna tongue. Even though the lower part of the glacial depression is occupied by lakes and mires, some glacial features may also be found in the bottom topography of Lake Rāzna (Fig. 11.2).

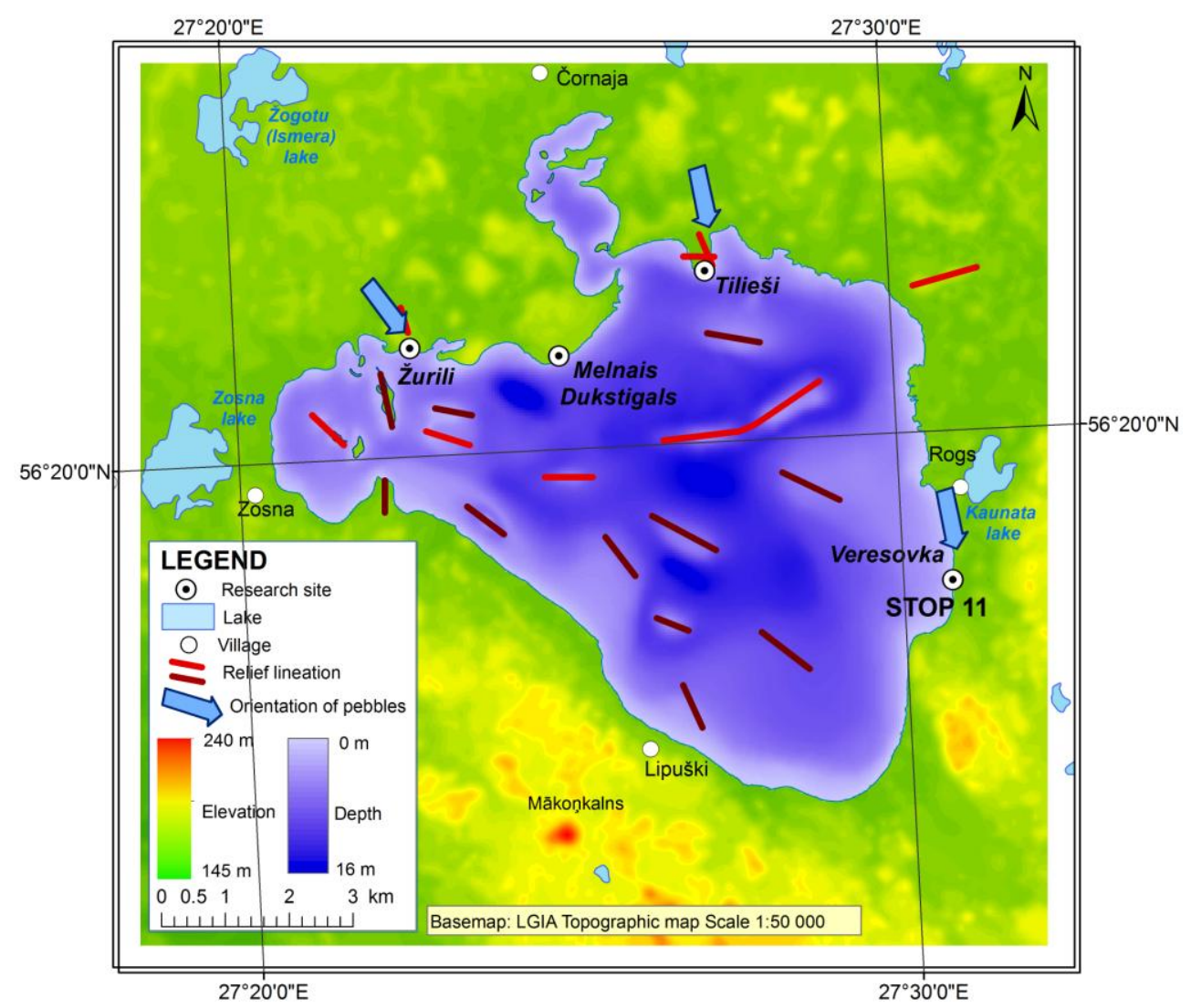

Fig. 11.2. Suspected glacial features of the Lake Rāzna bottom topography. Dark brown lines denote streamlined glacial landforms, while red lines indicate the position of the recessional moraine, stretching across the lake. Arrows indicate the dominant macrofabric linearity in subglacial till.

The Rāzna glacial depression corresponds to an elongated bedrock/pre-Weichselian depression. The bedrock surface dips slightly to NW. In the lower part of the depression its hypsometric position is less than $106 \mathrm{~m}$ a.s.l., increasing to $114-119 \mathrm{~m}$ a.s.l. on both sides. The bedrock is Upper Devonian clay, dolomite and gypsum. The Kaldabruna ice marginal zone coincides with a gentle slope consisting of Upper Devonian dolomite. The thickness of the Pleistocene deposits varies from 50-60 $\mathrm{m}$ to 70-85 $\mathrm{m}$. The maximum thickness occurs on the highest part of the interlobate hummocky moraine and ice-marginal ridge. Mākoņkalns Hill (Wolkenberg), which is located in the distal portion of the interlobate zone and is the highest point in the adjoining area, reaches $247.4 \mathrm{~m}$ a.s.l., while the elevation of the Kaldabruņa ice-marginal ridge varies from $180 \mathrm{~m}$ to $215 \mathrm{~m}$ a.s.l.

The maximum elevation of the recessional moraine ridge at Veresovka is $169.8 \mathrm{~m}$. It rises 5-7 m above the lake level and almost $25 \mathrm{~m}$ above the deepest part of Lake Rāzna. Even though the proximal part of the moraine ridge has almost been washed out by wave activity in the lake, several outcrops along the lakeshore give an insight into the internal structure of this small, smooth-crested ice-marginal ridge, which marks a halt in the retreat of the Rāzna glacier tongue.

In general, the ridge is composed of sediments that have been deposited in subglacial, supraglacial and ice-marginal environments. Observations of internal structure provide 
evidence of glacial thrusting (Figs. 11.3 and 11.4) and/or mass movement (Figs. 11.5 and 11.6). Small, up to 3-m-thick thrust-faulted structures form a regressive series (Figs. 11.3 and 11.4) and are responsible for redistribution of the inicial thickness of the diamicton and ice contact stratified drift in the course of formation of the recessional moraine ridge.

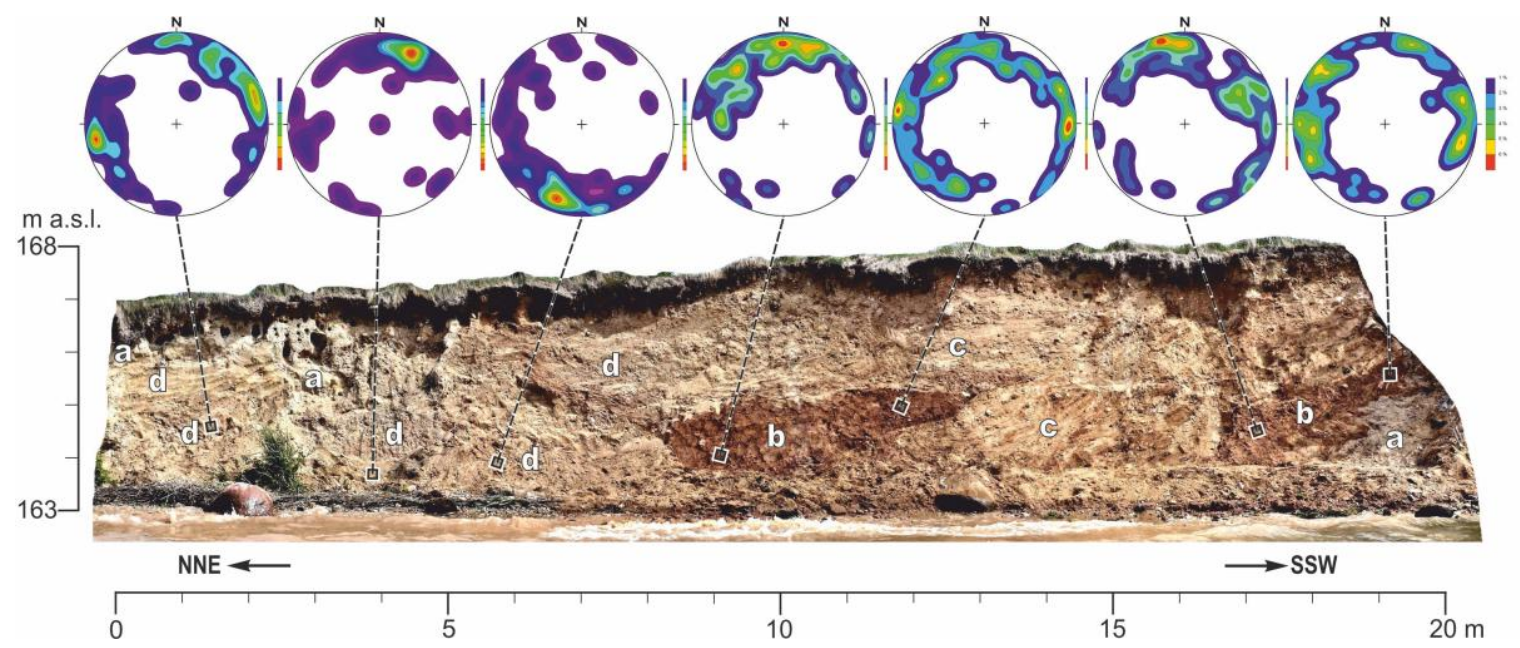

Fig. 11.3. Internal structure of the northernmost part of the recessional moraine in a section subparallel to the ridge crest. Legend: a - deformed sandy gravel with occasional cobbles; $b$ - moderate brown, massive, densely compacted, basal clayey sand diamicton (subglacial till); c -deformed stratified diamictic gravelly sand with chunks of laminated fines and diamicton lenses (supraglacial diamicton); d - matrix supported supraglacial diamicton.

Three-dimensional diagrams of till macrofabric are plotted on the lower hemisphere and in equal area projection. Based on 50 elongated clast measurements. Contoured at 0-1-2-4...14-16 percent areas.

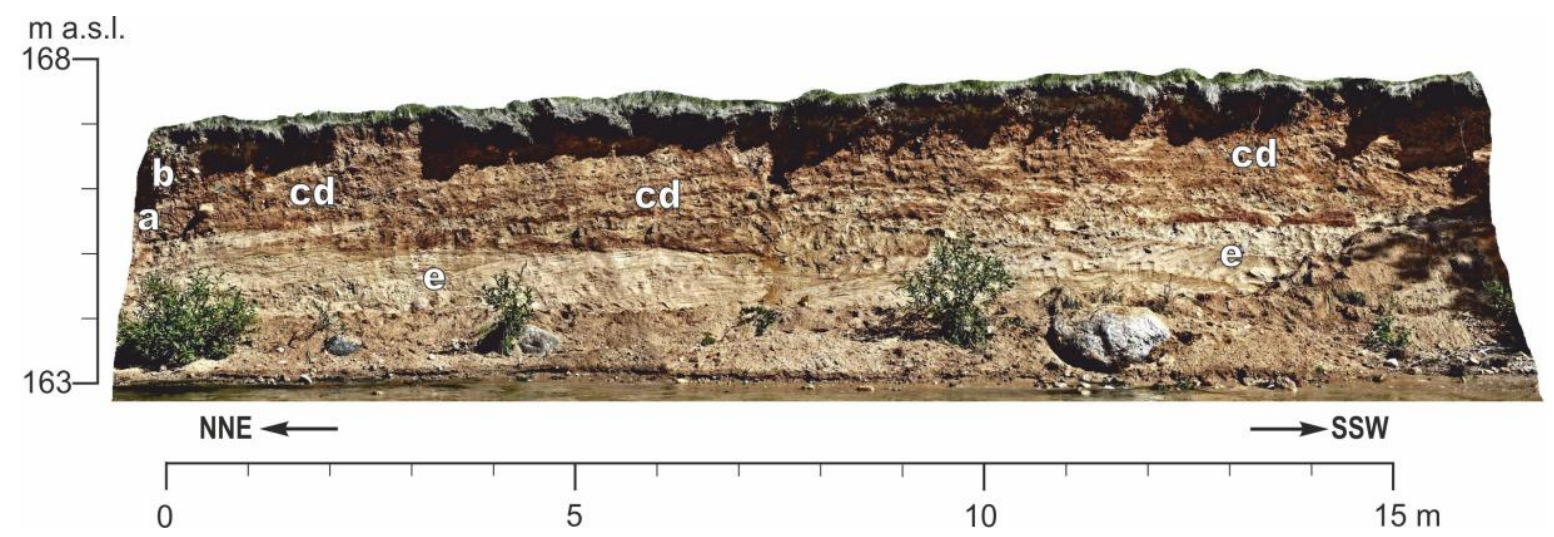

Fig. 11.4. Internal structure of the recessional moraine in a section located $7 \mathrm{~m} \mathrm{~S}$ of the section shown in Fig. 11.3. The section is subparallel to the ridge crest. Legend: $a$ - deformed sandy gravel with occasional cobbles; $b$ - moderate brown, massive, densely compacted, basal clayey sand diamicton (subglacial till); cd - deformed matrix supported diamictic sand with gravel and diamicton lenses (supraglacial diamicton); e - sheared trough cross-stratified and rippled gravelly sand, interlayered with silt and silty clay.

The imbricately stacked thrust scales largely consist of subglacial till derived from the glacier bed and supraglacial diamicton (Figs. 11.3 and 11.5), as well as supraglacial diamicton with sheared stratified drift (Fig. 11.4), or of altered stratified sediments in the southernmost part. As a result of thrusting, supraglacial till has been incorporated into the upper parts of the thrust scales (Fig. 11.3). The supraglacial till contains lenses and intercalations of stratified material with imprints of plastic and disruptive minor deformation. The weak multimodal macrofabric maxima, predominantly parallel to the recessional moraine crest and almost subperpendicular to ice flow direction, most likely indicate that subglacial till has been plastered 
onto a glacier bed in some earlier phase when the Rāzna tongue terminated at the Kaldabruna ice marginal zone. The wide dispersion of macrofabric lineation can be explained by its reorientation during formation of thrust-fault scales. In the section shown in Fig. 11.3 subglacial till is relative homogenous, but in the section shown in Fig. 11.5 it contains features common for subglacial deformation till. This till contact with the underlying supraglacial till is marked by a shear plane. In comparison to tills occurring in the northern part of recessional ridge, macrofabric linearity is quite strong and parallel to ice flow, while the macrofabric as well as the bedding planes dip downglacier. In the supraglacial till clast orientation maxima change from place to place and are rather chaotic. It is likely that the sandy gravel with occasional cobbles at the margin formed as ice-marginal fans due to re-deposition of the supraglacial diamicton, later reshaped by proglacial thrusting or flowage of diamicton above them.

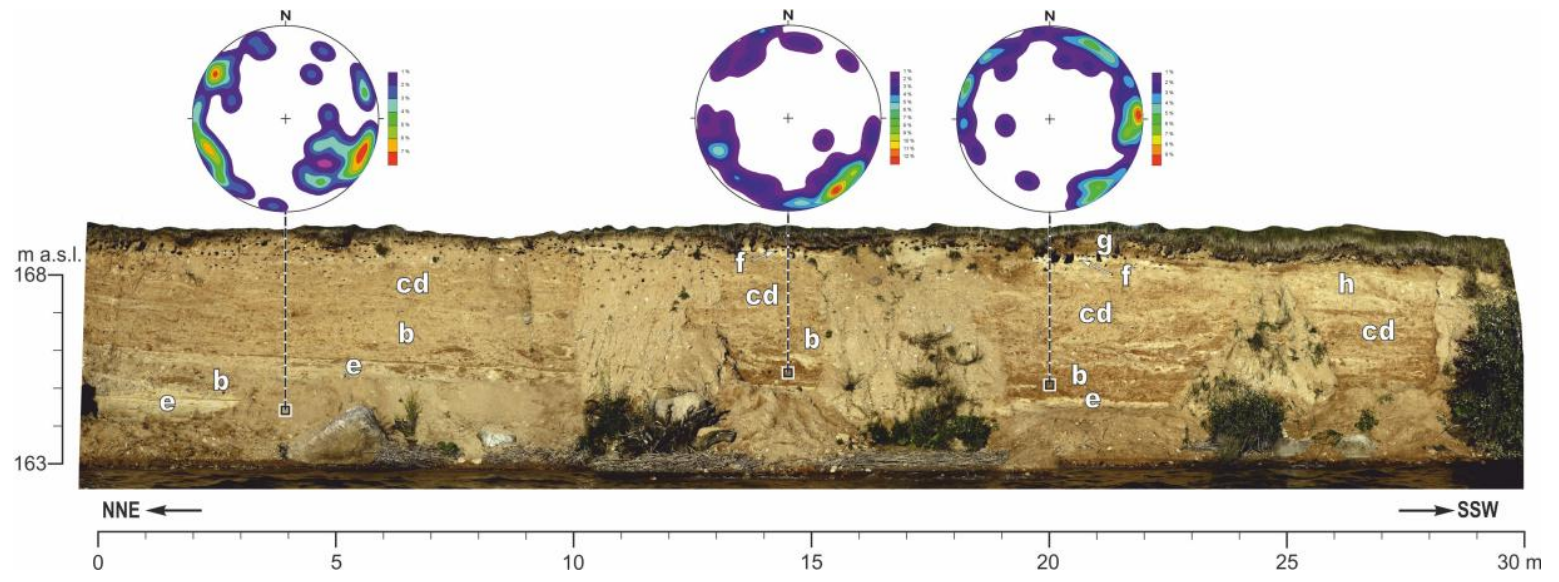

Fig. 11.5. Internal structure of the highest part of the recessional moraine ridge in a longitudinal section located $13 \mathrm{~m} \mathrm{~S}$ of the section shown in Fig. 11.4. Legend: $\mathrm{b}$ - moderate brown, basal clayey sand diamicton with deformed incorporated gravelly sand and finer material (subglacial till); cd - deformed matrix supported diamictic sand with gravel and diamicton lenses (supraglacial diamicton); e - sheared trough cross-stratified and rippled gravelly sand, interlayered with silt and silty clay; $\mathrm{f}$ - carbonate cemented sands; $\mathrm{g}$ - thinly laminated silt and clay with dropstones.

Three-dimensional diagrams of till macrofabric are plotted on the lower hemisphere and in equal area projection. Based on 50 elongated clast measurements. Contoured at 0-1-2...11-12 percent areas.

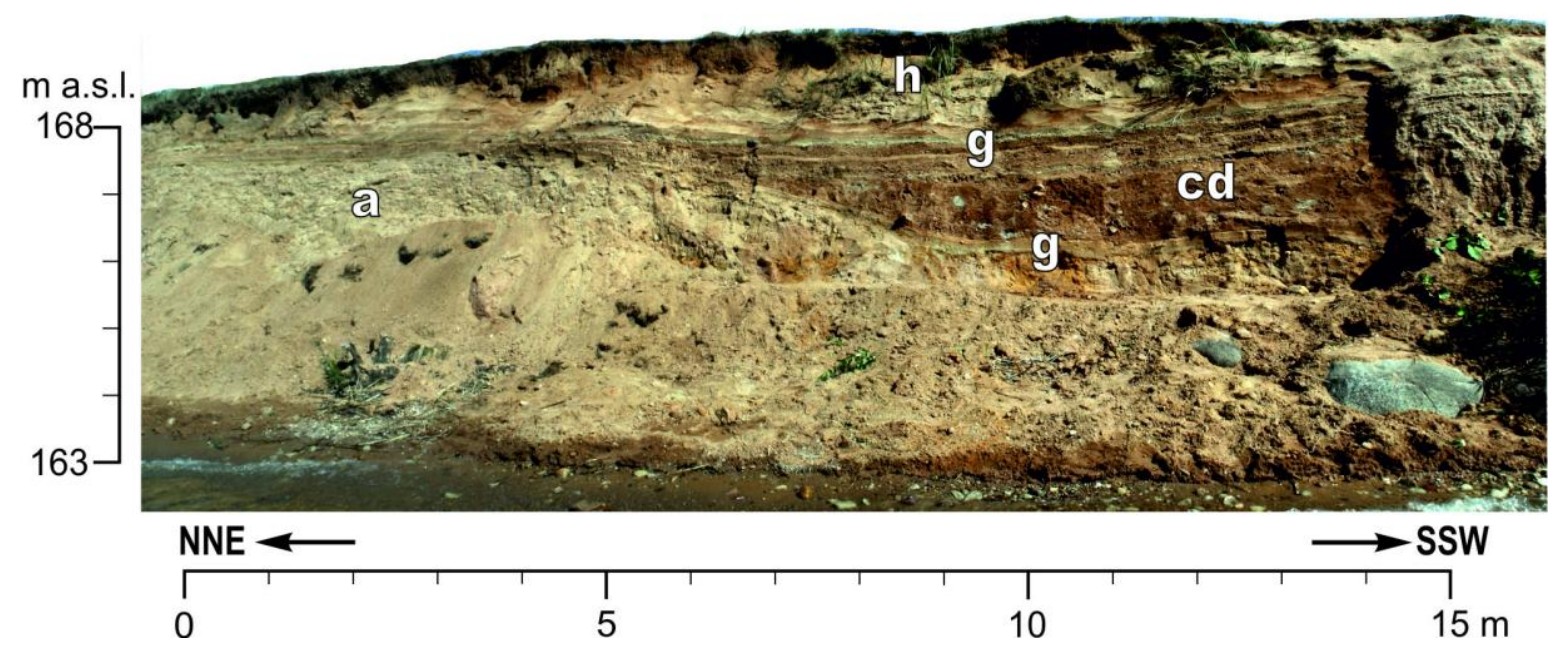

Fig. 11.6. Internal structure of the southern part of the recessional moraine ridge in a longitudinal section located $13 \mathrm{~m} \mathrm{~S}$ of the section shown in Fig. 11.5. Legend: a - deformed sandy gravel with occasional cobbles interlayered with sand; cd - deformed matrix supported diamictic sand with gravel and diamicton lenses (supraglacial diamicton); $\mathrm{g}$ - thinly laminated silt and clay with dropstones; $\mathrm{h}$ - coversand. 
In general, the internal structure and lack of subglacial meltwater drainage features attest that during formation of the recessional moraine ridge at Veresovka the glacier marginal part was frozen to the bed and longitudinal compressive ice flow conditions prevailed, which resulted in the formation of a small ice-marginal ridge. Evidently, the Rāzna tongue was covered by supraglacial drift. According to the exposed sequence (Figs. 11.3, 11.4 and 11.5) its maximum thickness could reach up to $2 \mathrm{~m}$. It might be assumed that supraglacial drift was effectively protecting the ice from melting and resulted in down-wasting of the glacier in situ, rather than an evident retreat of the glacier tongue terminus. Probably this and cold glacierbed condition also promoted also the formation of a solitary ridge instead of small composite ridges (according to the terminology of Aber et al. 1989).

\section{References}

Aber, J.S., Croot, D.G., Fenton, M.M. 1989. Glaciotectonic landforms and structures. Kluwer Academic Publishers, Dordrecht/Boston/London/, $201 \mathrm{pp}$.

Meirons, Z. 1975. The relief of the Latgale Elevation and the bordering areas of the East-Latvian Lowland. In Danilāns, I. (ed.), Problems of Quaternary Geology, 8. Rīga, Zinātne, pp. 48-81 (in Russian).

Zelčs, V., Markots, A. 2004. Deglaciation history of Latvia. In: Ehlers, J., Gibbard, P. L. (eds.), Quaternary Glaciations - Extent and Chronology. Part I: Europe. Developments in Quaternary Science, 2. Elsevier, Amsterdam, pp. 225-243.

Zelčs, V., Markots, A., Nartišs, M., Saks, T. 2011. Chapter 18: Pleistocene Glaciations in Latvia. In: Ehlers, J., Gibbard, P.L., Hughes, P.D. (eds.), Quaternary glaciations - extent and chronology. A closer look. Developments in Quaternary Science, 15. Elsevier, pp. 221-229. 


\title{
STOP 12: Late-glacial and Holocene development of Lake Rāzna as recorded by biostratigraphy
}

\author{
Sandra Zeimule ${ }^{\mathrm{a}}$, Laimdota Kalniņa ${ }^{\mathrm{a}}$ and Ieva Grudzinska ${ }^{\mathrm{b}}$ \\ ${ }^{\mathrm{a}}$ University of Latvia, Latvia \\ ${ }^{\mathrm{b}}$ Tallinn University of Technology, Estonia
}

The Lake Rāzna is the second largest lake by area and the biggest by volume in Latvia. It is located in the central part of the Latgale Upland (Fig. 12.1A) and occupies the lower part of the extensive glacial depression formed as a result of the activity of the Rāzna glacier tongue over the course of the last deglaciation (Meirons 1975; Zelčs and Markots 2004). The triangular lake narrows in the direction of the former ice flow, i.e. from NW to SE. The lake depression is surrounded by plateau-like hills, morainic hilly massifs, as well as, elementary and composite morainic ridges, whereas the depression itself shows traces of ribbed topography alternating with small depressions (Markots 2013). The complex topography and geological structure of the lake depression, and the character of its shores indicate the the complicated history and diversity of natural processes occurring in various parts of the lake. The sediments of the lake bear evidence of these spatial and temporal developments. The sedimentation environment of the shallow bays of Dūkstigals and Zosnasgals, located in the northern and the north-western part of the lake (Fig. 12.1B), differs to a great extent from that of the deeper part, which mainly contains minerogenic sediments consisting of sand, silt and clay. By contrast, the shallow bays have frequently accumulated organogenic sediments, i.e. gyttja and peat. Earlier investigations of the lake and its adjacent area, carried out by Alksnitis (1998), have mainly been connected with prospection for natural resources, not considering the depositional environment and lake development.
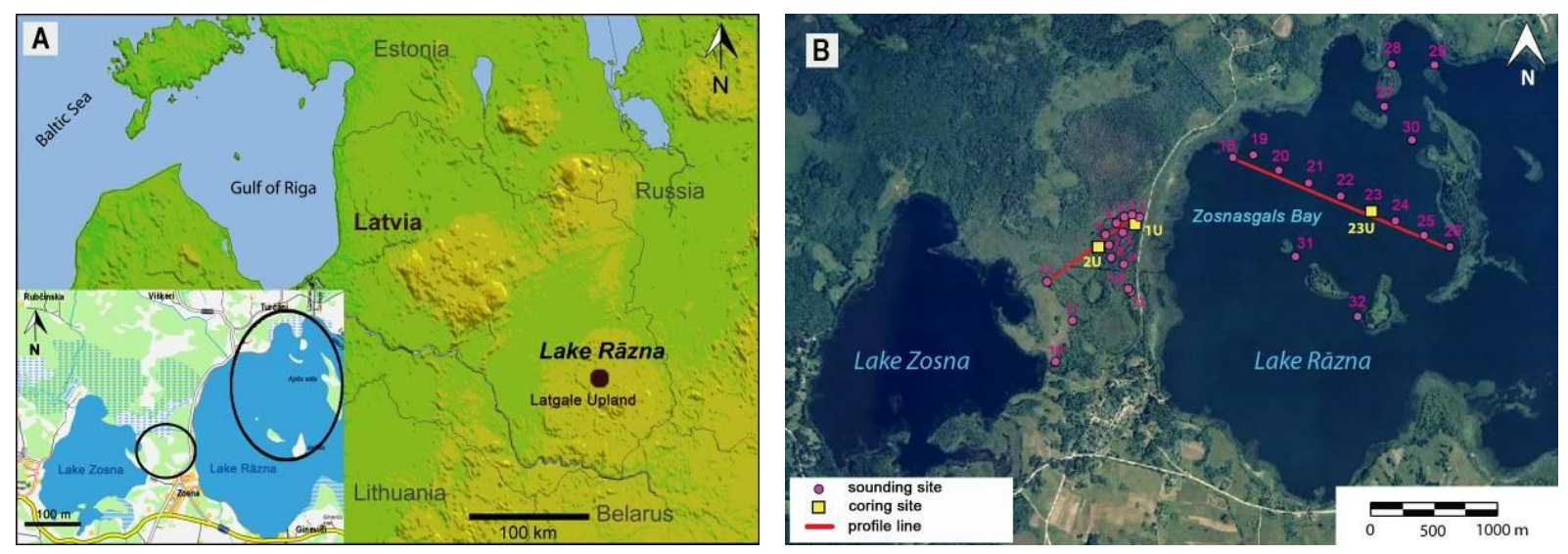

Fig. 12.1. The study area. A. Location of lakes Rāzna and Zosna. B. Location of sounding and coring sites.

The methods applied have been as follows: loss on ignition (LOI), plant macroscopic remain and pollen analyses, as well as identification of the botanical composition of peat, its degree of decomposition and sediment absolute age determination by radiocarbon dating. The results of this interdisciplinary study and their analysis gives an insight into the geological processes and time-transgressive changes in the depositional environment over the course of the lake's development (Zeimule 2013; Zeimule et al. 2014).

The Zosnasgals Bay sediment sequence and the macroscopic plant remains point to a changing depositional environment over the last 12,800 cal yr. According to radiocarbon dating results, the greyish sand at the base of the sediment sequence was deposited at 12800- 
12500 cal yr BP, i.e. in the late Younger Dryas (DR3), as distinguished by Hammarlund et al. (2003). The sand layer was recorded by sounding and coring, which showed that it is distributed in the entire elevated area between the lakes (see Fig. 12.1B for location). Similar processes took place at the same time in Zosnasgals Bay. LOI analysis shows that the content of mineral matter in this layer reaches $95 \%$ (Fig. 12.2A). During this time the vegetation at the lake was rather poor due to the cold and dry climate (Figs. 12.3, 12.4 and 12.5). The only aquatic plant species at the time was the slender-leaved pondweed (Potamogeton filiformis), whereas the seeds of birch (Betula sect. Albae), sedges (Carex sp.) and common bearberry (Arctostaphylos uva-ursi) might have been washed into the lake from the shoreline (Fig. 12.3). This idea is supported by the presence of sandy gyttja accumulated in the middle part, above the layer of sand at approximately 12,500-11,350 cal yr BP. The presence of sand is probably associated with shore erosion. The data from the analysis showed fluctuations in the water level during the Early Holocene (11,350-10,360 cal yr BP). In the eastern part of the elevated area (Fig. 12.1B) a layer of sand was deposited from 11,300 to 11,000 cal yr BP. It became covered by calcareous clay at 11,000-10,500 cal yr BP; this points to a higher water level in Lake Rāzna. Later it dropped again, as indicated by an increase in plant macroscopic remains, suggesting renewed growth of Bryozoa and oogonia in the Zosnasgals Bay sediments.

A
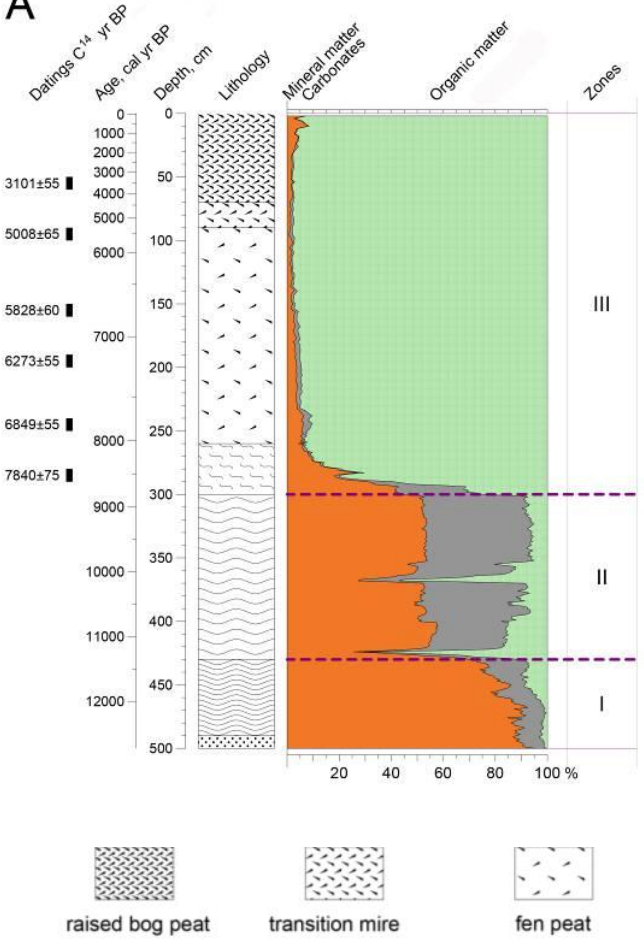

Fig. 12.2. A. Changes in the values of organic, mineral and carbonate matters in sediment composition. B. Agedepth model for the sediment section from core $2 \mathrm{U}$, Zosnasgals Bay. Calibrated ranges of ages and median ages of the samples are plotted against the depth from the sediment surface.

Study of the sediments from core $2 \mathrm{U}$ showed that several aquatic plant species started to grow on the shore of the bay during the period 10,360-8600 cal yr BP (Fig. 12.3). The slenderleaved pondweed was present in the bay during this period. The holly-leaved naiad (Najas marina) remained widespread during the early part of the period, whereas the yellow water lily (Nuphar lutea), the white water lily (Nymphaea alba), cattail (Typha sp.) and bulrush (Scirpus lacustris) appeared at the end of this time interval. A significant presence of oogonia and Bryozoa statoblasts shows that, with some exceptions, the water level in the bay was 
comparatively low.

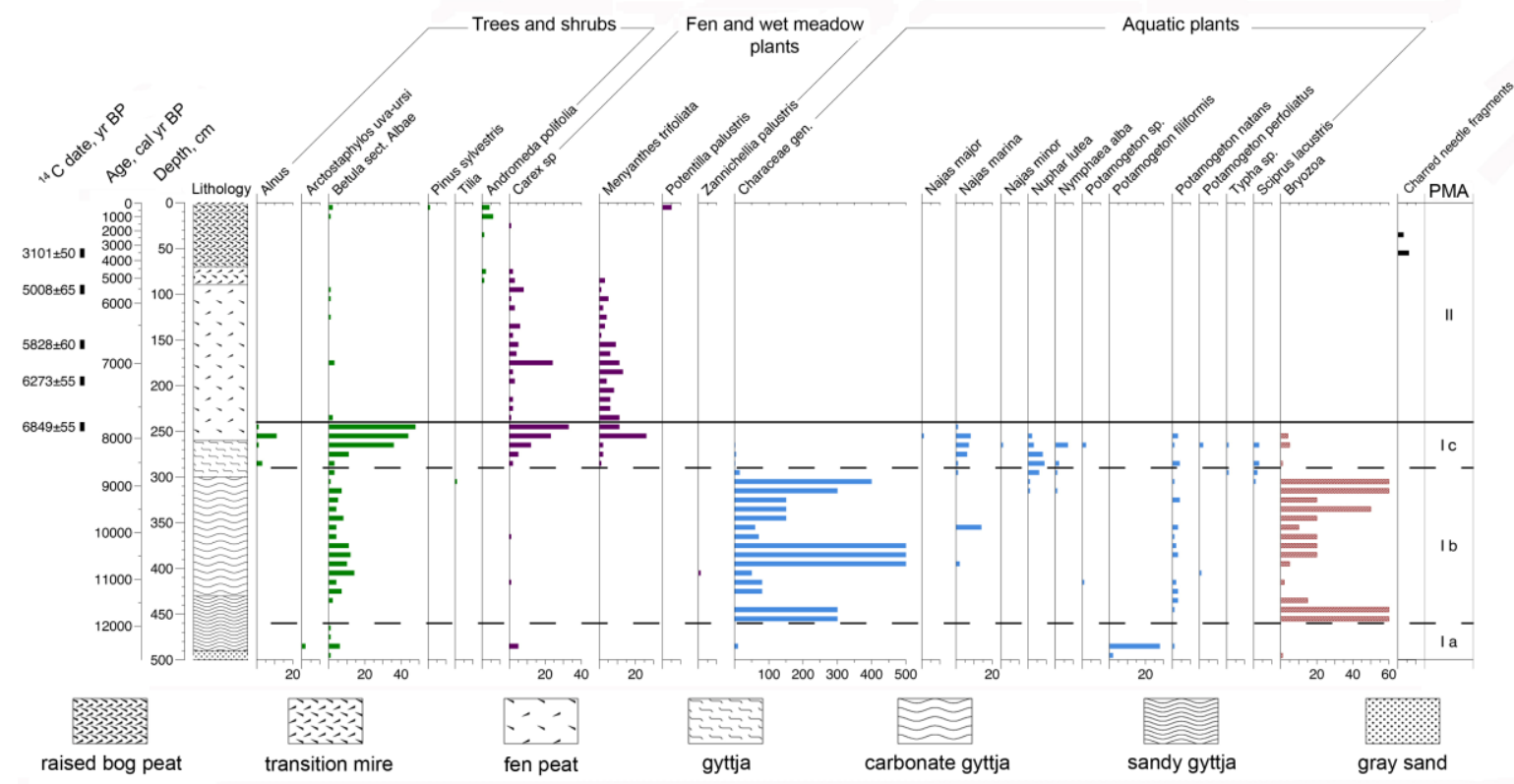

Fig. 12.3. Plant macroscopic remain diagram for thecore $2 \mathrm{U}$ sediment sequence. For location see Fig. 12.1B.

The changes in vegetation are also proven by pollen data reflecting regional vegetation, which leads to the conclusion that these changes were climatically induced. Pinus reaches its maximum $(60 \%)$ at the sediment depth $510 \mathrm{~cm}$, but already in the upper part of pollen zone PAZ ZG1 Pinus and Betula significantly decrease, while the amount of Picea pollen increases (Fig. 12.4). Among the herbs the ruderal plant pollen is dominated by Chenopodium and Artemisia, as well as pasture and meadow plants, mainly represented by Poaceae pollen (Fig. 12.5). The relationship between arboreal (AP) plant and nonarboreal (NAP) plant pollen indicates an open mosaic landscape in the first part of the Early Holocene.

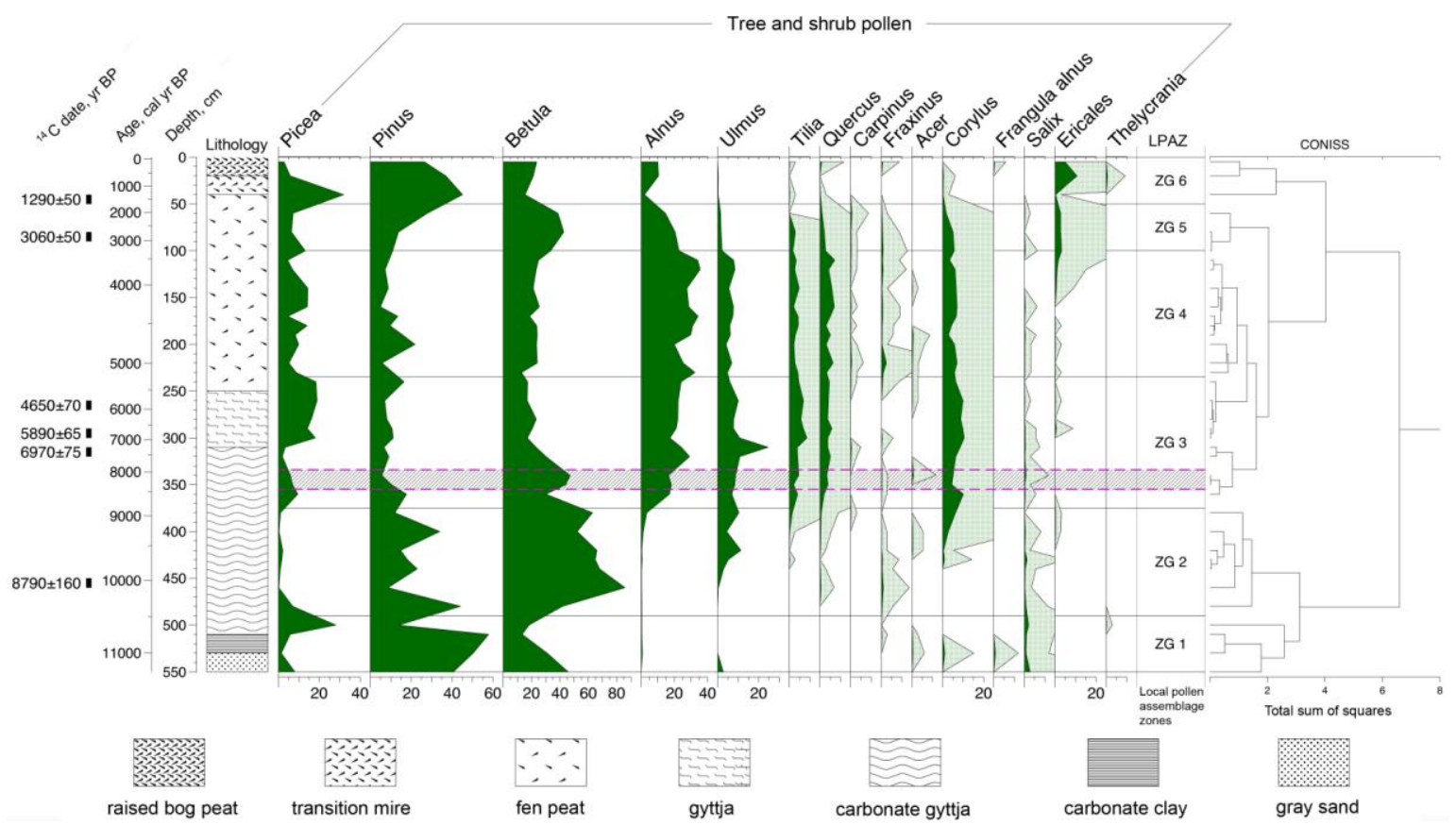

Fig. 12.4. Tree and shrub (AP) pollen percentage diagram from the Zosnasgals $2 \mathrm{U}$ sediment section. For location see Fig. 12.1B. 
During the time corresponding to the Holocene Thermal Maximum, well-decomposed fen-type peat started accumulating between lakes of Rāzna and Zosna. A sharp increase in organic matter in the sediment composition accompanied by more intensive sediment accumulation, is indicated by LOI analysis data (Fig. 12.3A) and by the depth-age model (Fig. 12.3B). This implies warm and dry climatic conditions causing the water level of the lake to drop and the shallowest places in the bay became overgrown. However, not all the shallow-water area in the elevated area separating the lakes was affected simultaneously.

At 8000 cal yr BP, the growth had already spread over the part of the elevated area closer to Lake Zosna, whereas at $5500 \mathrm{cal}$ yr BP it also spread to the part adjacent to Lake Rāzna. The period between 8600 and 7700 cal yr BP is marked by a significant change in the vegetation in the area of Zosnasgals Bay. Apart from lake vegetation, species typical for mires and wetlands, i.e., sedge and bogbean (Menyanthes trifoliata), appeared in a comparatively short time, which proves that the shores of the bay were growing over and the water body was turning into marshland. At the beginning of this time interval lake vegetation still had a somewhat dominant role.

The shore of the overgrowing bay was covered by holly-leaved naiad, yellow and white water lily and slender-leaved pondweed which typically grew next to water lily (Fig. 12.3). However, at the end of the period their number decreased, whereas the sedge and bogbean stands which replaced them indicate a shrinking water surface and excessive plant growth (Gałka et al. 2013). Notably, at 8000 cal yr BP the majority of lakes in Northern Europe were subject to excessive plant growth (Korhola et al. 2010).

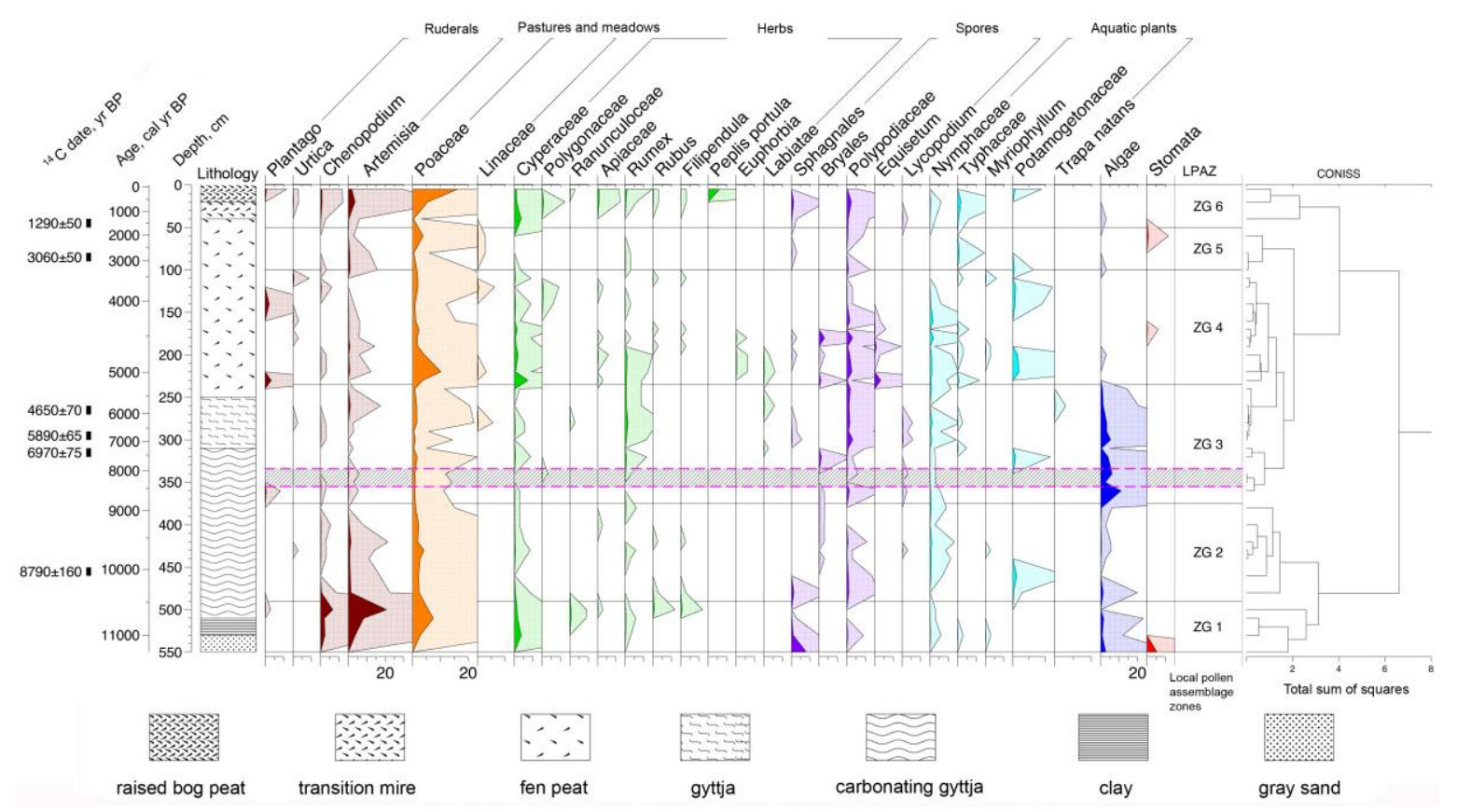

Fig. 12.5. Herb (NAP) pollen percentage diagram for the Zosnasgals $2 \mathrm{U}$ sediment section.

In the middle part of the elevated area (2U) fen conditions persisted from 7700-5330 cal yr BP, whereas in the eastern part (1U) aquatic plants were only becoming less widespread, with oogonia and Bryozoa statoblasts likewise disappearing during this time. At the end of the period propagation of typical marsh and wetland vegetation was common. The waterbody ceased to exist only at $5330 \mathrm{cal}$ yr BP, as demonstrated not only by a change in vegetation, but also by spore-pollen analysis, which indicates algae (typical of an aquatic environment) in the $550-240 \mathrm{~cm}$ deposition interval, whereas above $240 \mathrm{~cm}$ they are no longer present in the 
samples. Therefore, it could be concluded that with the overgrowing of the $1 \mathrm{U}$ area, the area of the palaeolake began to experience change.

The connection between Lake Rāzna and Lake Zosna disappeared, as an isthmus was formed more than $5300 \mathrm{cal} \mathrm{yr} \mathrm{BP}$ ago. Carbonate gyttja indicates increased sedimentation of carbonates in the lake between 9600 and 6500 cal yr BP. During this period the climate gradually became warmer and more carbonates were washed out of the bed of Lake Rāzna and the carbonate-rich glacial deposits around it.

The pollen diagram of the overgrown Zosnasgals Bay indicates two intervals of cold climatic spells, at $8200 \mathrm{cal}$ yr BP and at 3300-2500 cal yr BP, evidenced by a slight increase in mineral matter both in the overgrowing lakebed and in the sediments of the north-western part of Lake Rāzna (Figs. 12.4 and 12.5).

As shown by this study, the composition of the sediments and the changes in composition confirm the hypothesis that Lakes Rāzna and Zosna were part of a single large palaeolake in the late stage of the Late Glacial. With the lowering of the water level and more active overgrowth processes, the palaeolake was gradually divided into two separate lakes. This is also supported by the surface topography and sediment record. The results of the research lead to the conclusion that the palaeolake started overgrowing about 8000 years ago; initially starting with the shallower area separating the two lakes, and the palaeolake ceased to exist, being replaced by two separate lakes, Rāzna and Zosna.

\section{References}

Alksnītis, R. 1998. Pārskats par ezeru sapropę̧u atradņu meklēšanas darbiem Rēzeknes, Preiļu un Jēkabpils rajonos, 2. SIA „Ģeo-Konsultants”, Rīga, Valsts ǵeoloğijas fonds, Inv. No.11875, lpp. 6-141.

Gałka, M., Miotk-Szpiganowicz, G., Goslar, T., Jęśko, M., van der Knaap, W. O., Lamentowicz, M. 2013. Palaeohydrology, fires and vegetation succession in the southern Baltic during the last 7500 years reconstructed from a raised bog based on multi-proxy data. Palaeogeography, Palaeoclimatology, Palaeoecology, 370, 209-221.

Hammarlund, D., Bjorck, S., Buchardt, B., Israelson, C., Thomsen, C. T. 2003. Rapid hydrological changes during the Holocene revealed by stable isotope records of lacustrine carbonates from Lake Igelsjon, southern Sweden. Quaternary Science Reviews, 22, 353-370.

Korhola, A., Ruppel, M., Seppä, H., Väliranta, M., Virtanen, T., Weckström, J. 2010. The importance of northern peatland expansion to the late-Holocene rise of atmospheric methane. Quaternary Science Reviews, 29, 611-617.

Markots, A. 2013. Plakanvirsas pauguru reljefs Austrumlatvijas augstienēs. Latvijas Universitāte, Rīga, 107 lpp.

Meirons, Z. 1975. The relief peculiriaties of the Latgale Elevation and the bordering areas of the East-Latvian Lowland. In: Danilāns, I. (ed.), Problems of Quaternary Geology, 8, Zinātne, Rīga, pp. 48-81 (in Russian, with English summary).

Zeimule, S., Kalniņa, L., Grudzinska, I. 2013. Rāznas ezera Zosnasgala lī̌ca nogulumu paleolimnoloǵiskie pētījumi. In: Grīne, I. (comp.), Latvijas Universitātes 71. zinātniskā konference. Geogrāfija. Geologija. Vides zinātne. Referātu tēzes. Rīga, LU Akadēmiskais apgāds, pp. 291-293.

Zeimule, S. 2013. Rāznas ezera aizaugušā Zosnasgala līča paleolimnologiskā izpēte. Latvijas Universitāte, Rīga, 87 lpp. (Mağistra darbs)

Zelčs, V., Markots, A. 2004. Deglaciation historry of Latvia. In: Ehlers, J., Gibbard, P. L. (eds.), Quaternary Glaciations - Extent and Chronology. Part I: Europe. Developments in Quaternary Science, 2. Elsevier, Amsterdam, pp. 225-243. 


\title{
STOP 13: Inland dune field near Daugavpils, East-Latvian Lowland
}

\author{
Edyta Kalińska-Nartiša ${ }^{\mathrm{a}}$, Juris Soms ${ }^{\mathrm{b}}$, Santa Strode $^{\mathrm{b}}$ and Māris Nartišs ${ }^{\mathrm{c}}$
}

\author{
${ }^{\text {a }}$ University of Tartu, Estonia \\ ${ }^{\mathrm{b}}$ Daugavpils University, Latvia \\ ${ }^{\mathrm{c}}$ University of Latvia, Latvia
}

The landforms of aeolian origin located in the eastern and northern parts of Daugavpils town, as well as to the north and to the west of the town, represent one of the largest inland dune fields in Latvia. This dune field is located at the south-eastern edge of the East-Latvian Lowland, covering at least $260 \mathrm{~km}^{2}$ of the southern part of the Jersika Plain.

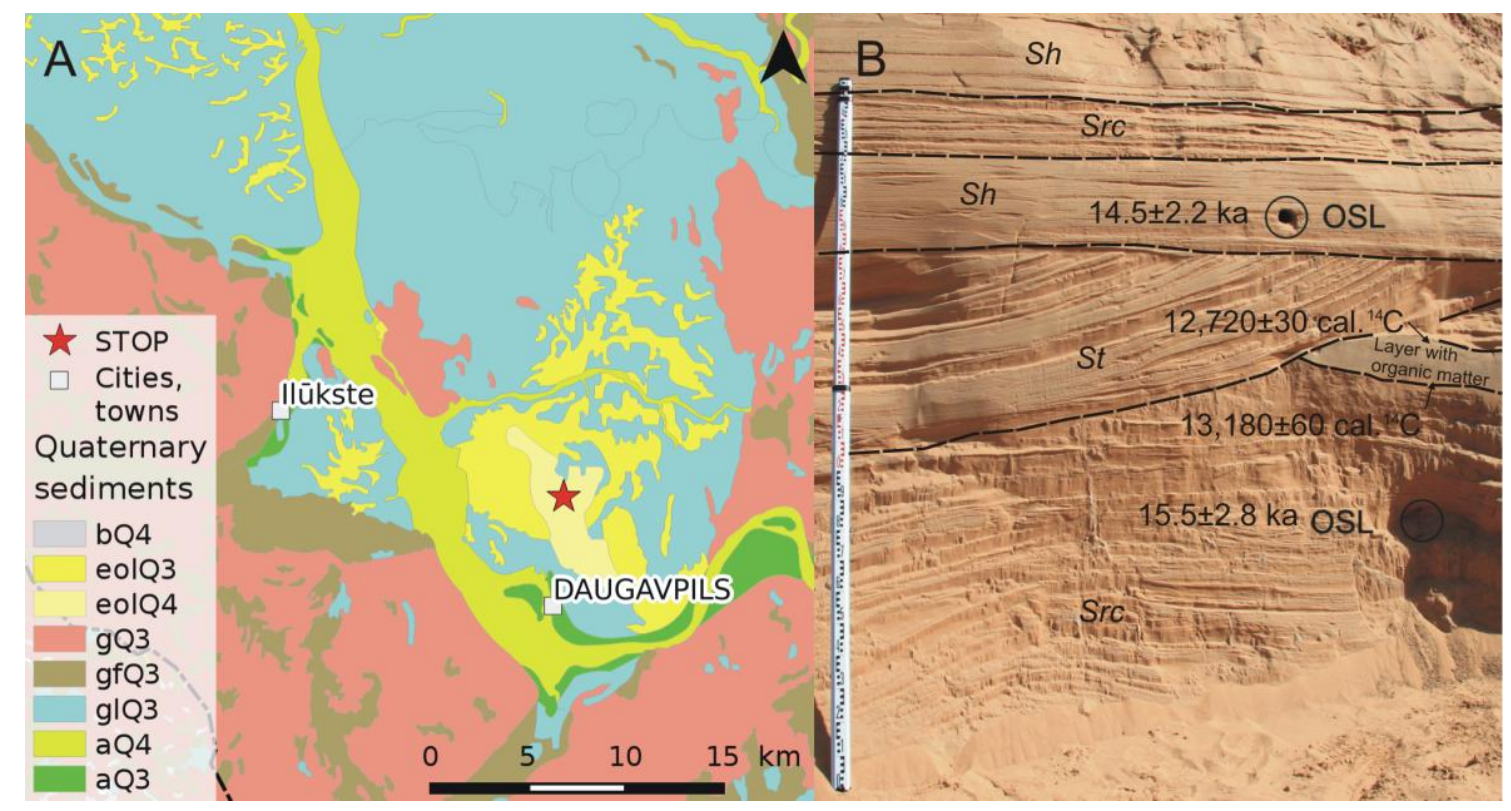

Fig. 13.1. A - Location of the investigated site and its surroundings on the Quaternary sediment map (Juškevičs and Skrebels 2003): bQ4 - peat, eolQ3 - older aeolian sand, eolQ4 - younger aeolian sand, gQ3 - glaciogenic sediments, gfQ3 - glaciofluvial sand and gravel, glQ3 - glaciolacustrine sand and silt, aQ4 - younger alluvial sediments, aQ3 - older alluvial sediments; B - Sedimentary succession, luminescence and radiocarbon age at the investigated site. Lithofacies symbols are distinguished by Miall's code (Miall 1978, 1977).

According to Eberhards (1972), the inland dunes have developed on the surface of the River Daugava paleodelta, which reflects an event of glaciofluvial sedimentation in the Nìcgale ice dammed lake (Fig. 13.1A) during the Younger Dryas. After the drainage of the glacial lake, the abundance of unconsolidated sediments, lack of vegetation cover and climatic conditions favoured the transportation of sand and fine sandy material by wind and the formation of aeolian landforms.

Despite the evidence of past aeolian activity in this area, under modern climatic conditions the dune field has been almost entirely stabilized by canopy vegetation, mainly represented by Scots pine forest, which prevents mobilization of the sand by aeolian processes. Although information about this area as an inland dune field was presented in the literature more than 30 years ago (Straume 1979, 1984), the morphology and spatial distribution of aeolian landforms located in this part of Latvia, their internal structure and chronology of formation still remain poorly documented.

Analysis of topographic maps at scale 1:10,000 with a contour interval $2 \mathrm{~m}$ and remote sensing data have made it possible to identify within the dune field more than 340 dunes of 
different morphology; many of them have an asymmetric profile and parabolic shape in planar view. The results also indicate that many of the dunes form groups which are randomly scattered across the dune field.

The altitude of the dunes varies from 90 to $138 \mathrm{~m}$ a.s.l. The highest dunes are Alu kalns ('Burrow Hill'), Spaidu kalns ('Coercion Hill') and Plikais kalns ('Bare Hill'), which reach altitude of $139.5,125$ and $124.7 \mathrm{~m}$ a.s.l., respectively. Notable is that the altitudes of the dunes generally decrease from south-east to north-west, i.e. from the proximal to distal direction of the paleodelta of the River Daugava.

The internal structure and geological composition of the dune field can be observed in the ca. 20 ha Käpas sand-pit, which is located $0.8 \mathrm{~km} \mathrm{SW}$ of the Gijantari railway stop. Due to sand excavation, 5 to $14 \mathrm{~m}$ high outcrops of Quaternary sediments have been formed; here the uppermost layers of glaciolacustrine sediments and covering aeolian sediments are available for detailed study.

The sedimentary succession of the Gijantari site (Fig. 13.1B) consists of sand with trough structure - St (Miall, 1977 1978), where intensive wind conditions are indicated by the presence of deflation thoughts - DT (Zieliński and Issmer 2008). A significant component is sand with translatent stratification and horizontal lamination - Src and $S h$, respectively, representing deposition by a gentle wind up to $6 \mathrm{~m} \mathrm{~s}^{-1}$ (c.f. Zieliński and Issmer 2008).

The major part of the Gijantari site consists of fairly homogeneous fine-grained sands with a mean $(\mathrm{Mz})$ value of between 1.51 and $2.78 \varphi$. Simultaneously an alternation of both coarser-grained $(\mathrm{Mz}=0.56 \varphi)$ and finer-grained $(\mathrm{Mz}=3.40 \varphi)$ laminae is visible. The alternating bedding of silty, fine and coarser sand can be attributed to the deposition and adhesion of sediments on an alternating dry and wet depositional sand sheet/dune surface and/or seasonal changes in wind velocity, as observed by Kasse (2002).

The analysis of the roundness of quartz sand grains and the character of their surface (see the description of the methodology in STOP 6) revealed the predominance of matted grains with various degrees of rounding; short-duration abrasion/transportation (EM/RM type) quartz grains prevail (7-32\%); however, a significant quantity of RM grains is also noted (6-22\%). Thus, the predominance of the aeolian factor could be confirmed. However, the period of aeolian activity could be established as having lasted some hundreds of years (Mycielska-Dowgiałło 1993) due to the evidence of aeolian action at the corners and edges of the quartz grains. The latter has been proved experimentally (Costa et al. 2013); aeolian transport for short distances and during a relatively short period of time is enough to imprint significant abrasion marks. Simultaneously, the increase in perfectly rounded RM grains seems to be unusual at localities in Latvia; this has been noted in areas with a significant duration of aeolian activity, i.e. in Central Poland (Cailleux 1942; Goździk 2007). The cause of this remains unexplained, however it is considered (Mazzullo 1986) that aeolian sorting preferentially removes well-rounded quartz grains from the source. Therefore a high proportion of rounded grains can be observed in the downwind deposits, leaving behind a deflation lag with a high proportion of angular grains. Similarly, inheritance/transformation in relation to the former/parental deposits is indicated, where the entire shape of the grain is considered as crucial for further aeolian abrasion; angular grains reveal a tendency to become almost spherical (Kuenen 1960). Shiny quartz grains (EL and EM/EL) indicate a river floodplain or an estuarine shore face in a temperate climate (Marks et al. 2014). Up to 34\% of these have been noted at the Gijantari site, which is rather unique for an aeolian setting. However, a similar outline has been noted within the aeolian sand-sheets in Central Poland (Kalińska 2012) and the aeolian complexes in Ukraine (Zieliński et al. 2009). Postsedimentary frost weathering is responsible for a high content of cracked (C) quartz grains 
(Woronko and Hoch 2011); up to $32 \%$ of such grains have been observed. The latter could therefore indicate seasonal frost action within the open cracks in the surface of frozen ground (Ribolini et al. 2014).

The relationship between quartz, feldspars, crystalline rocks and micaous minerals is significant for assessing the mineralogical maturity and inferring the sediment source and provenance (i.e. Kasper-Zubillaga and Zolezzi-Ruiz 2007). Dune sands are considered multicyclic, being derived from pre-existing recycled sediments (Howari et al. 2007). A significant occurrence of feldspars and crystalline rocks (19-29\% altogether) indicates a nearby source and suggests that the major part of the sediments did not pass through several sedimentary cycles.

An intercalated layer with organic matter has been found in the middle part of the dune (Fig. 13.1B). In order to construct a timescale, two AMS ${ }^{14} \mathrm{C}$ dates obtained from Beta Analytic INC were calibrated at the one- $\delta$ confidence level using the IntCall3 calibration curve (Reimer et al. 2013). The macroscopic charcoal fragments collected from the lower and upper organic layers yielded AMS radiocarbon ages of $13,180 \pm 60$ and $12,720 \pm 30{ }^{14} \mathrm{C} \mathrm{BP}$, respectively (unpublished data). These correspond to the Allerød-Younger Dryas boundary (Steffensen et al. 2008; van Hoesel et al. 2014) or the GS-1 to GI-1a-b in the NGRIP stratigraphy (Blockley et al. 2012). These dates can be assumed to mark the lower limit of accumulation of the aeolian sediments which cover the dated organic matter. They also demonstrate good agreement with other published data from north-eastern Lithuania (Stančikaite et al. 2009) and eastern Latvia (Heikkilä et al. 2009; Veski et al. 2012) on the development of vegetation in these areas.

Simultaneously, two luminescence ages (Fig. 13.1B) were obtained at the Finnish Museum of Natural History Dating Laboratory, Helsinki, Finland for the sandy sediment units directly below and above the organic layer. Equivalent dose $(D e)$ determination was carried out using the single-aliquot regenerative dose (SAR) protocol (Murray and Wintle 2000). A consistent age of $15.5 \pm 2.8$ and $14.5 \pm 2.2 \mathrm{ka}$ (unpublished data) was obtained. Within the limits of uncertainty, the luminescence ages agree with the AMS ${ }^{14} \mathrm{C}$ datings. However, with respect to the optical age results, the relatively high errors, in the range of $15-18 \%$, must be noted. Clearly, these have to be reinvestigated.

\section{References}

Blockley, S.P.E., Lane, C.S., Hardiman, M., Rasmussen, S.O., Seierstad, I.K., Steffensen, J.P., Svensson, A., Lotter, A.F., Turney, C.S.M., Bronk Ramsey, C. 2012. Synchronisation of palaeoenvironmental records over the last 60,000 years, and an extended INTIMATE event stratigraphy to 48,000 b2k. Quaternary Science Reviews, 36, 2-10.

Cailleux, A. 1942. Les actiones éoliennes périglaciaires en Europe. Mémoires de la Société Géologique de France, 41, 1-176.

Costa, P.J.M., Andrade, C., Mahaney, W.C., Marques da Silva, F., Freire, P., Freitas, M.C., Janardo, C., Oliveira, M. a., Silva, T., Lopes, V. 2013. Aeolian microtextures in silica spheres induced in a wind tunnel experiment: Comparison with aeolian quartz. Geomorphology, 180-181, 120-129.

Eberhards, G. 1972. Stroyeniye i razvitiye dolin basseyna peki Daugava [Structure and development of valleys of the Daugava river basin]. Zinātne, Rīga, 131 pp. (In Russian).

Goździk, J. 2007. The Vistulian aeolian succession in central Poland. Sedimentary Geology, 193, 211-220

Heikkilä, M., Fontana, S.L., Seppä, H. 2009. Rapid Lateglacial tree population dynamics and ecosystem changes in the eastern Baltic region. Journal of Quaternary Science, 24, 802-815.

Howari, F.M., Baghdady, Goodell, P.C. 2007. Mineralogical and gemorphological characterization of sand dunes in the eastern part of United Arab Emirates using orbital remote sensing integrated with field investigations. Geomorphology, 83, 67-81.

Juškevičs, V., Skrebels J. 2003. Map of the Quaternary deposits. In: Āboltiňš, O., Brangulis,A.J. (eds.), Geological Map of Latvia. Scale 1:200,000. Sheet 34-Jēkabpils. Sheet 24-Daugavpils. Explanatory Text and Maps. State Geological Survey of Latvia, Rīga. 
Kalińska, E. 2012. Geological setting and sedimentary characteristics of the coversands distributed in the western part of the Blonie glaciolacustrine basin (Central Poland) - preliminary results. Bulletin of the Geological Society of Finland, 84, 33-44.

Kasper-Zubillaga, J.J., Zolezzi-Ruiz, H. 2007. Grain size, mineralogical and geochemical studies of coastal and inland dune sands from El Vizcaíno Desert, Baja California Peninsula, Mexico. Revista Mexicana de Ciencias Geologicas, 24, 423-438.

Kasse, C. 2002. Sandy aeolian deposits and environments and their relation to climate during the Last Glacial Maximum and Lateglacial in northwest and central Europe. Progress in Physical Geography, 26, 507532.

Kuenen, P.H. 1960. Experimental abrasion 4: Eolian action. Journal of Geology, 4, 427-449.

Marks, L., Gałązka, D., Krzymińska, J., Nita, M., Stachowicz-Rybka, R., Witkowski, A., Woronko, B., Dobosz, S. 2014. Marine transgressions during Eemian in northern Poland: A high resolution record from the type section at Cierpięta. Quaternary International, 328-329, 45-59.

Mazzullo, J.I.M. 1986. The effects of eolian sorting and abrasion upon the shapes of fine quartz sand grains. Journal of Sedimentary Petrology, 56, 45-56.

Miall, A.D. 1977. Lithofacies types and vertical profile models in braided river deposits: a summary. Fluvial Sedimentology, 5, 597-604.

Miall, A.D. 1978. Lithofacies types and vertical profile models in braided river deposits: a summary. In: Miall, A.D. (ed.), Fluvial Sedimentology. Canadian Society of Petroleum Geologists Memoir, 5, pp. 597-604.

Murray, A.S., Wintle, A.G. 2000. Luminescence dating of quartz using an improved single-aliquot regenerativedose protocol. Radiation Measurements, 32, 57-73.

Mycielska-Dowgiałło, E. 1993. Estimates of Late Glacial and Holocene aeolian activity in Belgium, Poland and Sweden. Boreas, 22, 165-170.

Reimer, P.J., Bard, E., Bayliss, A., Warren Beck, J., Blackwell, P.G., Bronk Ramsey, C., Buck, C.E., Cheng, H., Edwards, R.L., Friedrich, M., Grootes, P.M., Guilderson, T.P., Haflidason, H., Hajdas, I., Hatte, C., Heaton, T.J., Hoffmann, D.L., Hogg, A.G., Hughen, K.A., Kaiser, K.F., Kromer, B., Manning, S.W., Niu, M., Reimer, R.W., Richards, D.A., Scott, E.M., Southon, J.R., Staff, R.A., Turney, C.S.M., van der Plicht, J. 2013. Intcal13 and Marine13 radiocarbon age calibration curves 0-50,000 years cal BP. Radiocarbon, $55,1869-1887$.

Ribolini, A., Bini, M., Consoloni, I., Isola, I., Pappalardo, M., Zanchetta, G., Fucks, E., Panzeri, L., Martini, M., Terrasi, F. 2014. Late-Pleistocene Wedge Structures Along the Patagonian Coast (Argentina): Chronological Constraints and Palaeo-Environmental Implications. Geografiska Annaler: Series A, Physical Geography, 96(2), 161-176.

Stančikaitè, M., Kisielienè, D., Moe, D., Vaikutienè, G. 2009. Lateglacial and early Holocene environmental changes in northeastern Lithuania. Quaternary International, 207, 80-92.

Steffensen, J.P., Andersen, K.K., Bigler, M., Clausen, H.B., Dahl-Jensen, D., Fischer, H., Goto-Azuma, K., Hansson, M., Johnsen, S.J., Jouzel, J., Masson-Delmotte, V., Popp, T., Rasmussen, S.O., Röthlisberger, R., Ruth, U., Stauffer, B., Siggaard-Andersen, M.-L., Sveinbjörnsdóttir, A.E., Svensson, A., White, J.W.C. 2008. High-resolution Greenland ice core data show abrupt climate change happens in few years. Science, 321, 680-684.

Straume, J. 1979. Sovremenniy relyef Latvii. Nelednikoviye obrazovaniya: Eolovaya gruppa. In: Misans, J., Brangulis, A. (eds.), Geologicheskoye stroyeniye i poleznye iskopayemye Latvii. Zinātne, Rīga, pp. 347348 (in Russian).

Straume, J. 1984. Sovremenniye geologicheskiye processi i yavleniya [Modern geological processes and phenomena]. In: Misans, J., Brangulis, A., Straume, J. (eds.), Geologiya Latviyskoy SSR. Obyasnitel'naya zapiska $k$ geologicheskim kartam Latviyskoy SSR 1:500000. Zinātne, Rīga, pp. 143-144 (in Russian).

Van Hoesel, A., Hoek, W.Z., Pennock, G.M., Drury, M.R. 2014. The Younger Dryas impact hypothesis: a critical review. Quaternary Science Reviews, 83, 95-114.

Veski, S., Amon, L., Heinsalu, A., Reitalu, T., Saarse, L., Stivrins, N., Vassiljev, J. 2012. Lateglacial vegetation dynamics in the eastern Baltic region between 14,500 and 11,400calyrBP: A complete record since the Bølling (GI-1e) to the Holocene. Quaternary Science Reviews, 40, 39-53.

Woronko, B., Hoch, M. 2011. The development of frost-weathering microstructures on sand-sized quartz grains: examples from Poland and Mongolia. Permafrost and Periglacial Processes, 227, 214-227.

Zieliński, P., Fedorowicz, S., Zaleski, I. 2009. Sedimentary succession in Berezno in the Volhynia Polesie (Ukraine) as an example of depositional environment changes in the periglacial zone at the turn of the Vistulian and the Holocene. Geologija, 51, 97-108.

Zieliński, P., Issmer, K. 2008. Propozycja kodu genetycznego osadów środowiska eolicznego. Przegląd Geologiczny, 56, 67-72. 


\section{STOP 14: Morphology and internal structure of the Lāči drumlin at Tērvete village, Zemgale Drumlin Field}

Kristaps Lamsters and Vitālijs Zelčs

University of Latvia

The Lāči drumlin is located on the western side of the Zemgale Drumlin Field. It is the highest drumlin in the environs of Tērvete (Fig. 14.1). The drumlin is $3.3 \mathrm{~km}$ long, $1.8 \mathrm{~km}$ wide and up to $18 \mathrm{~m}$ high on the stoss side, which is $67.6 \mathrm{~m}$ a.s.l. The drumlin has a rather classic shape, because it narrows and lowers in the distal direction. Its longitudinal axis strikes NNE-SSW, which corresponds to the regional ice flow direction. The internal structure of the drumlin was examined in the Lāči sand pit $\left(23^{\circ} 24^{\prime} 10^{\prime \prime} \mathrm{E}, 56^{\circ} 27^{\prime} 38^{\prime \prime} \mathrm{N}\right)$.

The glacial topography of this area formed during the initial reactivation and oscillatory retreat of the Late Weichselian Fennoscandian Ice Sheet in the North Lithuanian deglacial phase (locally termed the Linkuva phase after Meirons et al. 1976). The flow of the Zemgale ice lobe that advanced in the Central Latvian Lowland was highly divergent (Zelčs et al. 1990, 2011), as indicated by the orientation of glacial lineations (Lamsters 2012; Lamsters and Zelčs 2013). The extent of the Zemgale ice lobe during the North Lithuanian glacial phase in southcentral Latvia and north-central Lithuania is marked by the Linkuva end moraine (Āboltiņš 1970), also called the North Lithuanian marginal ridge by Karmazienè et al. (2013). The ice margin retreated from the North Lithuanian moraine position at $13.3 \pm 0.7{ }^{10} \mathrm{Be} \mathrm{ka}$ (Rinterknecht et al. 2008).

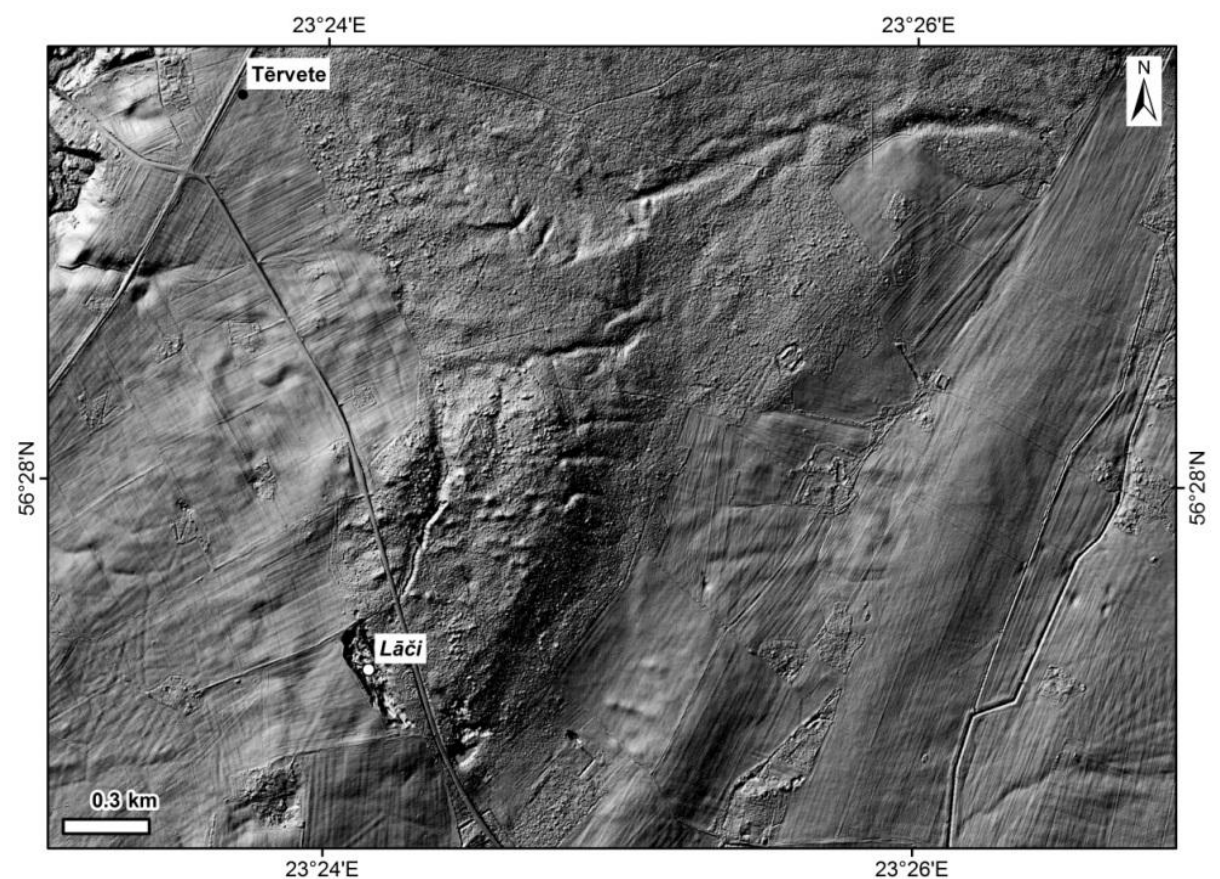

Fig. 14.1. Glacial topography in the vicinity of Tērvete, consisting of NNE-SSW striking drumlins. Note the largest drumlin and the Lāči sand pit in the lower left part of the picture. Relief-shaded DEM with grid size of 2 m. Courtesy of METRUM Ltd.

In the SW part of the Zemgale drumlin field the bedrock surface is composed of Upper Devonian Famennian sedimentary rocks. The bedrock surface increases in the direction of ice motion from $0 \mathrm{~m}$ a.s.l. in the $\mathrm{N}$ up to $70 \mathrm{~m}$ a.s.l. in the SW. The thickness of the Pleistocene, 
mainly Weichselian, deposits in this area varies from a few metres to $20 \mathrm{~m}$, although it reaches $40 \mathrm{~m}$ on the highest glacial landforms. Upglacier from the Linkuva end moraine the Pleistocene deposits consist of two till beds interbedded with sorted sediments (Dreimanis and Zelčs 1995; Zelčs and Markots 2004).

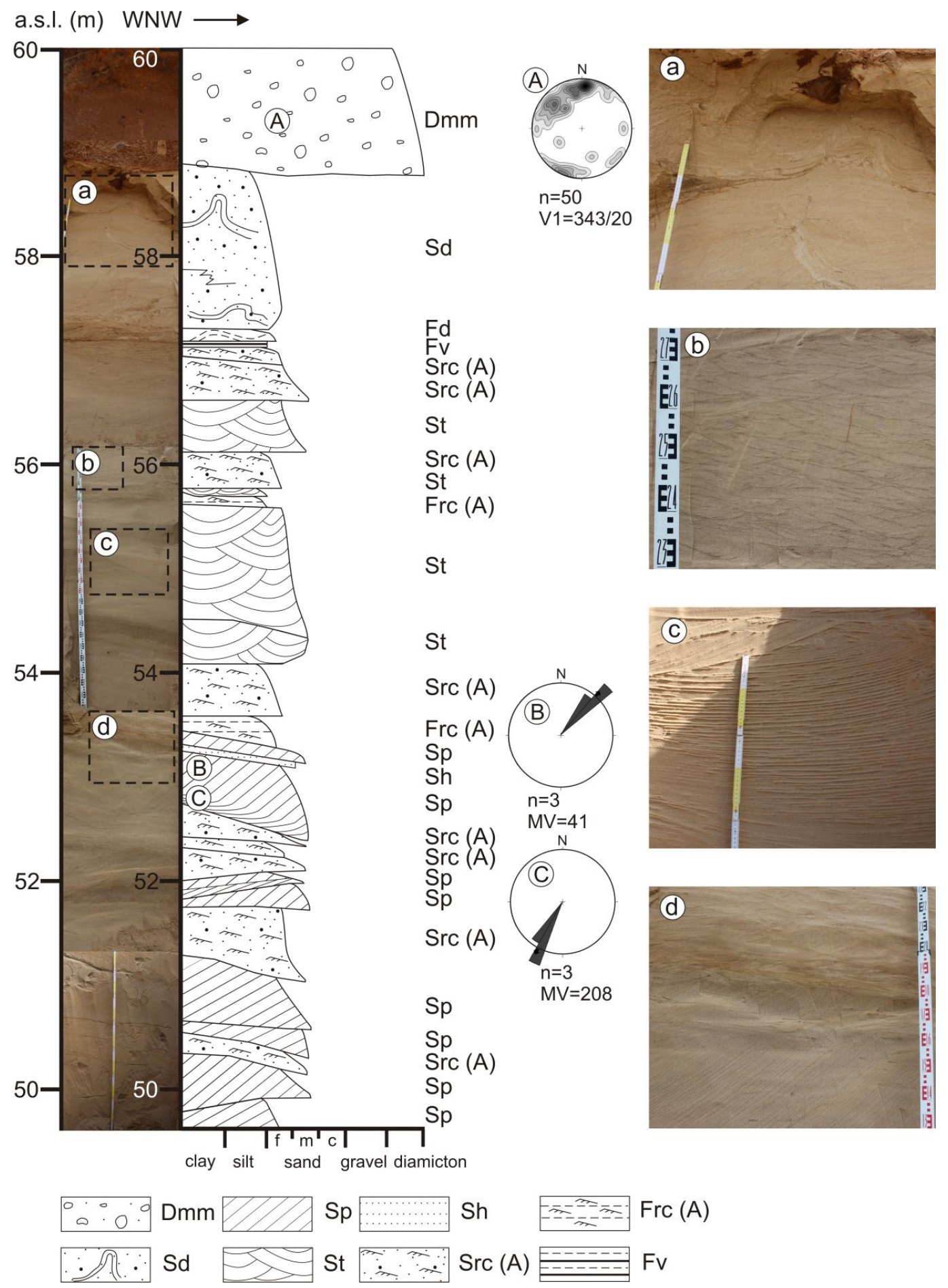

Fig. 14.2. Section at the Lāči sand pit showing glaciolacustrine sediments in the core of the drumlin. Legend: Dmm - diamicton, matrix supported, massive; Sp - planar cross-bedded sand; Sh - horizontal-laminated sand; Frc (A) - subcritically climbing-ripple cross-laminated silt; $\mathrm{Sd}$ - deformed sand; St - trough cross-bedded sand; Src (A) - subcritically climbing-ripple cross-laminated sand; Fv - parallel laminated silt, clay. Description for close-up photographs: (a) - deformed sand; (b) - sand with subcritically climbing-ripple cross-lamination; (c) trough cross-bedded sand; (d) - planar cross-bedded sand and subcritically climbing-ripple cross-laminated sandy silt in the upper part. 
The Lāči drumlin consists of stratified sediments that are capped by subglacial till a few metres thick (Figs. 14.2 and 14.3). The stratified sediments (Fig. 14.2) are composed mostly of silty to medium-grained sand that is deformed to a depth of 1-4 m. The sand is mainly planar cross-bedded, trough cross-bedded, horizontal-laminated or climbing-ripple crosslaminated.
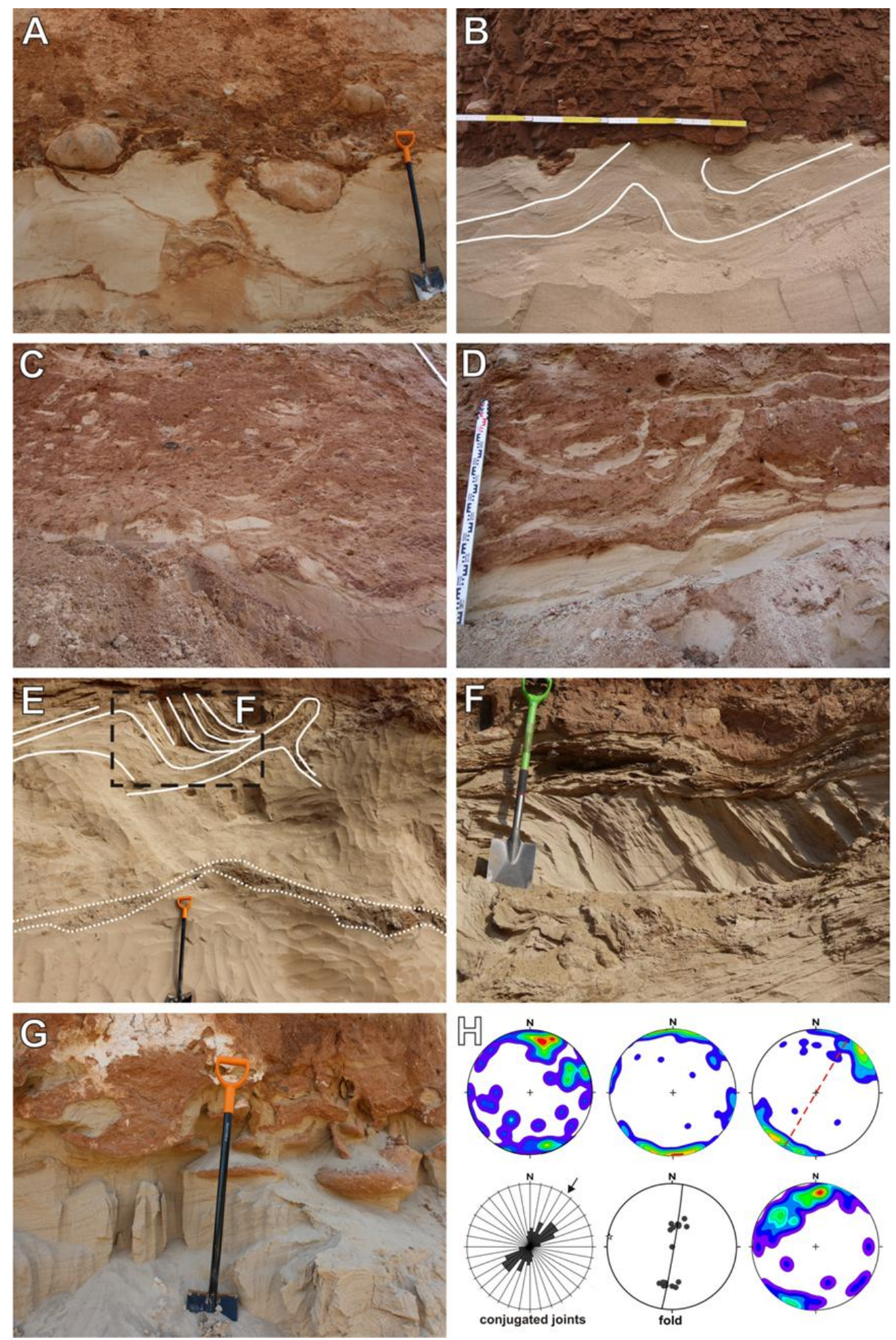

Fig. 14.3. Structures in the subglacial till forming the drumlin and underlying sandy sediments at the Laači sand pit. A. Subglacial till underlain by deformed sandy sediments. Note lodged boulders at the base of till, deformed till stringers and significant inclusion of till/silt in sandy sediments. B. Subglacial traction till with clearly visible shear planes and sub-vertical joints underlain by slightly folded fine sand. Note the almost sharp contact. C. 
Deformation till with highly attenuated and deformed sand lenses and intraclasts. Note that sand intraclasts become more deformed and rounded upwards. D. Deformation till with less attenuated, folded and boudinaged sand laminae. E. Deformed sandy sediments at a depth of at least $4 \mathrm{~m}$. Note the clearly visible asymmetrical folds just below till and deformed till lens underneath (white dotted line). F. Close-up photograph of Fig. 14.3E. Note sub-vertically bedded sand in the limb of the fold and the shear zone that cuts the upper part of the fold. G. Density driven deformation structures at the contact between till and sand. H. Stereo plots of till fabric, conjugated joints and fold structural measurements. The orientation of the drumlin crest is shown in the till fabric plot by a red line. Till fabric measurements were taken within subglacial till at different locations in the Lāči sand pit.

The prevalence of silty and fine-grained sand, less often sandy silt or even a thin clay layer, indicate glaciolacustrine sedimentation in the proximal part of a basin with high sediment supply and fluvial activity. Unfortunately, we do not know the precise time of deposition of the sediments found in the Lāči sand pit, but it is likely that they were deposited in the basin during Middle Weichselian time interval (Lejasciems interstadial in Latvia after Zelčs and Markots 2004). There are dating results from glaciolacustrine sediments on the western side of the Central Latvian lowland, giving the following OSL ages: $26.9 \pm 4.4 \mathrm{ka}$ (Hel-TL04113, Kažoki 01 site), 29.4 \pm 4.7 ka (Hel-TL04114, Kažoki 02 site) (Zelčs et al. 2011).

The ice stress direction in the drumlin was defined from measurements of the till macrofabric, constructed drag fold hinges and conjugate joints. The hinges of asymmetric folds in the sandy sediments strike perpendicular and sub-perpendicular to the crest of the drumlin (Fig. 14.3E, H). Till fabric and conjugate joints indicate ice stress variation, mostly from N-S to NE-SW (Fig. 14.3H). The determined ice stress direction is parallel or subparallel to the orientation of the longitudinal axis of the drumlin. Such fabrics, which trend approximately parallel with the drumlin crest or diverge slightly from it, have been observed frequently (Stokes et al. 2011).

Observations of the till indicate that it is likely to have been formed as subglacial lodgement till. It is characterized by well-developed fissility. Lodged clasts, faceted and striated boulders and pebbles are not uncommon. Boulders with striated lower surfaces at the base of the till present evidence that they were incorporated into the debris-rich basal part of the ice that was sliding over its bed. It is also evident from shear fractures and sand intraclasts that the till was subsequently deformed, and so could be interpreted as traction till after Evans et al. (2006). Contacts between till and underlying sand are often gradual (deformed), but erosional contacts also occur (Fig. 14.3).

It is possible to distinguish the deformation till where it is characterised by attenuated, folded and boudinaged sand laminae (Fig. 14.3D) or so-called tectonic/depositional slices of Boulton et al. (2001). In places more pervasive till deformation is common, where more attenuated sand laminas and intraclasts are visible (Fig. 14.3C). Gradual contacts and the sometimes smudgy appearance of the sand intraclasts suggest that they were incorporated into the base of the subglacial deforming layer. Strong basal ice/bed coupling and high pore-water content is also proposed; this led to the observed mixing of till and sand sediments. In places the result of this mixing is seen in the form of till blocks in a sand matrix. The possibility cannot be excluded that sandy sediments were initially frozen and that some of them remained partially frozen during deformation, because sand intraclasts are relatively well preserved in places and are not fully homogenized. In other parts observed density-driven deformation structures (dewatering) at the contact between till and sand (Fig. 14.3G) suggest high porewater content in sediments. The observed structures and contacts between till and underlying sandy sediments indicate floating pore-water pressure that resulted in episodes of ice/bed coupling and decoupling. Such conditions can best be explained by the mosaic ice-bed deformation model (Piotrowski et al. 2004), which may be applied at different scales. The 
Lāči drumlin was formed due to partial erosion/deformation of pre-existing sediments and accumulation/deformation of till.

\section{References}

Āboltinšs, O. 1970. Marginal formations of Middle Latvian tilted plain and their correlation to Linkuva (North Lithuanian) end moraine. In: Danilāns, I. (ed.), Problems of Quaternary geology, V. Zinātne, Rīga, pp. 95-107 (in Russian, with English summary).

Boulton, G.S., Dobbie, K.E. \& Zatsepin, S. 2001. Sediment deformation beneath glaciers and its coupling to the subglacial hydraulic system. Quaternary International, 86, 3-28.

Dreimanis, A., Zelčs, V. 1995. Pleistocene stratigraphy of Latvia. In: Ehlers, J., Kozarski, S., Gibbard, P. (eds.), Glacial Deposits in North-East Europe. Balkema, Rotterdam/Brookfield, pp. 105-113.

Evans, D.J.A., Phillips, E.R., Hiemstra, J.F., Auton, C.A.,2006. Subglacial till: formation, sedimentary characteristics and classification. Earth Science Reviews, 78(1-2), 115-176.

Karmazienè, D., Karmaza, B., Baltrūnas, V. 2013. Glacial geology of North Lithuanian ice marginal ridge and surrounding plains. Baltica, 26(1), 57-70.

Lamsters, K. 2012. Drumlins and related glaciogenic landforms of the Madliena Tilted Plain, Central Latvian Lowland. Bulletin of the Geological Society of Finland, 84(1), 45-57.

Lamsters, K., Zelčs, V. 2013. Glacial lineations in the Central Latvian Lowland and adjoining plains of North Lithuania. In: Satkūnas, J., Guobyte (eds), Palaeolandscapes from Saalian to Weichselian, South Eastern Lithuania. Abstracts of International Field Symposium, June 25-30, 2013, Vilnius-Trakai, Lithuania. Lithuanian Geological Survey, Vilnius, pp. 62-64.

Meirons, Z., Straume, J., Juškevics, V. 1976. Main varieties of the marginal formations and retreat of the last glaciation in the territory of Latvian SSR. In: Danilāns, I. (ed.), Problems of Quaternary Geology, 9. Zinātne, Rīga, pp. 50-73 (in Russian, with English summary).

Piotrowski, J. A., Larsen, N. K., Junge, F. W. 2004. Reflections on soft subglacial beds as a mosaic of deforming and stable spots. Quaternary Science Reviews, 23, 993-1000.

Rinterknecht, V. R., Bitinas, A., Clark, P. U., Raisbeck, G. M., Yiou, F., Brook, E. J. 2008. Timing of the last deglaciation in Lithuania. Boreas, 37(3), 426-433.

Stokes, C. R., Spagnolo, M., Clark, C. D. 2011. The composition and internal structure of drumlins: complexity, commonality, and implications for a unifying theory of their formation. Earth-Science Reviews, 107, 398422.

Zelčs, V., Markots, A., Strautnieks, I. 1990. Process formirovaniya drumlinov Sredne-Latviyskoy gliatsiodepressionnoy nizmennosti (The formation of drumlins in the Central Latvian Lowland). In: Eberhards, G., Zelčs, V., Vanaga A. (eds.), Acta Universitatis Latviensis, 547, 111-130 (in Russian).

Zelčs, V., Markots, A. 2004. Deglaciation history of Latvia. In: Ehlers, J., Gibbard, P. L. (eds.), Quaternary Glaciations - Extent and Chronology. Part I: Europe. Developments in Quaternary Science, 2. Elsevier, Amsterdam, pp. 225-243.

Zelčs, V., Markots, A., Nartišs, M., Saks, T. 2011: Chapter 18: Pleistocene Glaciations in Latvia. In: Ehlers, J., Gibbard, P.L., Hughes, P.D. (eds.), Quaternary glaciations - extent and chronology. A closer look. Developments in Quaternary Science, 15. Elsevier, pp. 221-229. 


\section{STOP 15: Morphology and internal structure of a ribbed moraine and drumlin remnant in the environs of Baldone, Central Latvian Lowland}

Kristaps Lamsters and Vitālijs Zelčs

University of Latvia

Mašēni and Aizvējas are two sand pits located on a composite angular-shaped hummock with a relative height of up to $40 \mathrm{~m}$ and an extent of approximately $1.5 \times 1.7 \mathrm{~km}$ (Fig. 15.1). The NE part resembles a remnant of a drumlin, oriented parallel to the regional ice flow direction (NNW-SSE). The Aizvējas sand pit $\left(24^{\circ} 20^{\prime} 12^{\prime \prime} \mathrm{E}, 56^{\circ} 46^{\prime} 17^{\prime \prime} \mathrm{N}\right)$ is located on this drumlin-like ridge, whereas the Mašeni sand pit $\left(24^{\circ} 20^{\prime} 19^{\prime \prime} \mathrm{E}, 56^{\circ} 45^{\prime} 32^{\prime \prime} \mathrm{N}\right)$ is located on the ribbed moraine ridge. The overall morphology of the Zemgale ribbed moraines is characterized by two sets of ridges that are perpendicular to each other, caused by ribbed moraine superimposition on drumlins (Zelčs 1993; Zelčs and Dreimanis 1998), but more complex landforms are found in the NE part of the Zemgale ribbed moraine field in the environs of Baldone (Lamsters and Ošs 2012). The Zemgale ribbed moraine area lies in the Upmale hummocky plain between the Iecava drumlin field in the west and the marginal formations of the North Lithuanian glacial phase, the so-called Valle ridge (Āboltiņš 1970), in the east. A number of ribbed moraines are also found on the Ropaži Plain, west of the Madliena drumlin field (Lamsters 2012).

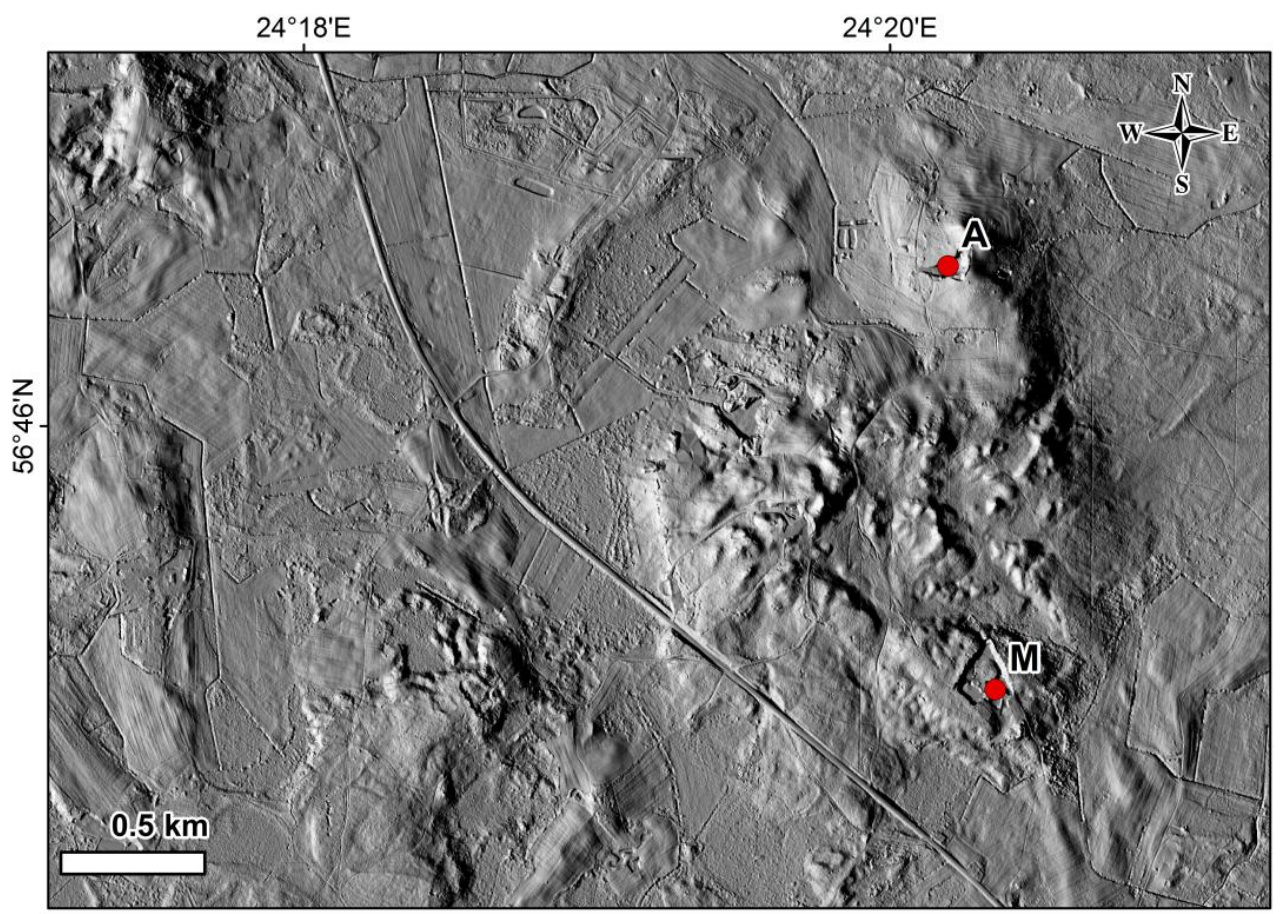

Fig. 15.1. Topography of the complex ribbed moraine ridge and drumlin remnant in the environs of Baldone. Relief-shaded DEM with grid size of $2 \mathrm{~m}$. Courtesy of METRUM Ltd.

In the Upmale hummocky plain the bedrock surface is composed of Upper Devonian Frasnian sedimentary rocks. Beneath the ribbed moraine under consideration the bedrock consists of dolomite and marl with interlayers of clay. Gypsum layers are also found closer to Baldone (Naumenko and Jankins 1999). In general the bedrock surface lowers in the $\mathrm{W}$ and NW direction from $40 \mathrm{~m}$ to $-5 \mathrm{~m}$ a.s.l. The Pleistocene cover is on average from a few metres up to $20 \mathrm{~m}$ thick, although it is thicker in some individual hummocks in the surroundings of Baldone, reaching a maximum of $45 \mathrm{~m}$. 

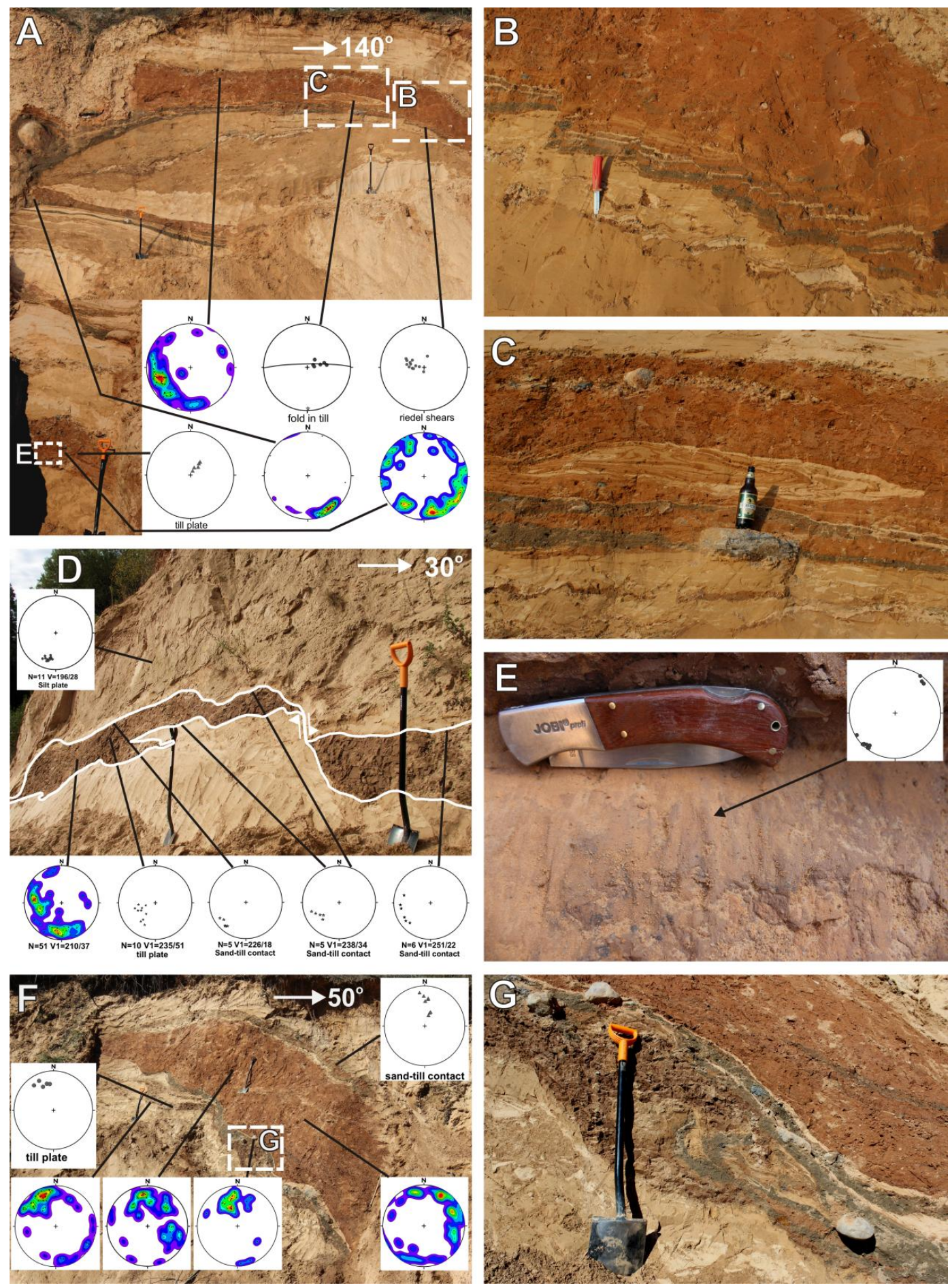

Fig. 15.2. Internal structure of the ribbed moraine in the Mašèni sand pit. A. View of the outcrop parallel to the ice-flow direction, with four distinct, different-coloured till beds. B. Small faults (Riedel shears) in the topmost till bed and underlying silty sediments; see location in Fig. 15.2A. C. Recumbent fold in the topmost till bed consisting of a mixture of sand/silt/diamictic material; see location in Fig. 15.2A. D. View of the outcrop transverse to the ice-flow direction with a sequence of deformed silt/diamictic/sand sediments. E. Internal slickenside in the lowermost till bed, showing a grooved surface; see location in Fig. 15.2A; F. View of the outcrop transverse to the ice flow direction, showing an obvious till thrust sheet; G. Close-up photograph of three different-coloured tills deformed together with underlying silt/sand; see location in Fig. 15.2F.

The Pleistocene sequence generally consists of at least two Weichselian till beds and sorted sediments between them, although observations of the internal structure of the ribbed moraines in the vicinity of Daugmales Tomēni provide evidence of up to five Weichselian till 
beds underlain by one or two possible Saalian till beds (Dreimanis 1935; Dreimanis and Zelčs 1995; Zelčs and Dreimanis 1998). Such a complicated and glaciotectonically disturbed structure is also observed in the Mašēni sand pit, where the Pleistocene sequence is made of at least four distinct till beds interbedded with deformed sorted sediments (Fig. 15.2A), and of one till bed at the base of the ribbed moraine. This structure most likely originated through successive subglacial thrusting under a compressional ice flow regime, as also reported by Stokes et al. (2008).

Three outcrops were investigated in detail in the Mašēni sand pit (Fig. 15.2). One of these is parallel (Fig. 15.2A) and the next two are transverse (Fig. 15.2D, F) to the former regional direction of the ice flow. The first outcrop is $11 \mathrm{~m}$ high and consists of four diamicton units interbedded with silt, silty and fine grained sand. This structure is interpreted as imbricated thrust sheets (Fig. 15.2A). The lower till bed is brown, densely compacted and brecciated, whereas the three upper beds are banded deformation tills consisting of differentcoloured layers. The upper part of the topmost diamicton bed is composed of reddish-brown till with greenish-grey till and sand intercalations at the bottom. It contains a recumbent fold with the hinge striking in a N-S direction (Fig. 15.2C), and faults that resemble Riedel shears (Fig. 15.2B). A very thin interlayer of deformed brown till is also found between the two upper tills (Fig. 15.2B, C). Three till fabric plots that were measured in different till beds have fabric maxima dipping towards WSW and SSE. The lineations (grooves) on the internal slickenside (Fig. 15.2E) in the lower till bed trend NE-SW. The measured structural data indicate variable ice stress directions. It is possible that the till fabric was re-oriented due to widespread glaciotectonic deformation, which is evident from abundant plastic and brittle deformation structures.

The first of the transverse outcrops (Fig. 15.2D) consists of 1-m-thick till in the upper part, which is underlain by up to $4 \mathrm{~m}$ thick silt and up to $1 \mathrm{~m}$ thick brown fissile till. This sequence is underlain by silty and fine-grained deformed sand. The structural measurements of till fabric, till plates, till and sand/silt contacts dip in the direction between $\mathrm{W}$ and S (Fig. 15.2D).

The second of the transverse outcrops is located in a 13-m-high wall. It consists of deformed fine sand and silt disrupted by a diamicton (Fig. 15.2F). It is up to $4 \mathrm{~m}$ thick, thinning towards the top. The diamicton is composed of the same three different coloured till layers as described previously. The thicker one is a reddish-brown, massive sandy till layer. The other tills are only a few centimetres to decimetres thick and underlie the reddish-brown till. The contacts between tills and sand/silt are very deformed - mixed together and folded (Fig. 15.2G). The greenish-grey till is characterized by a concentration of cobbles and boulders that dip to NNW. The plots of reddish-brown till macrofabrics and till plate also indicate the ice stress direction, from NNW, which coincides with the regional ice movement direction.

A 12-m-high outcrop striking N-S was investigated in the Aizvējas sand pit (Fig. 15.3A). It is composed of deformed fine/silty sand and silt overlain by 4 to $5 \mathrm{~m}$ thick massive, in the upper part fissile reddish brown subglacial till. The lower part of this till is deformed and contains sand inclusions and one upward-injected sand dyke (Fig. 15.3C). An ice wedge pseudomorph was found in the upper part of the till (Fig. 15.3B), indicative of permafrost conditions after glacier retreat.

The second outcrop consists of a 3-m-high section of deformed silt and sand sediments intercalated with five, up to $40 \mathrm{~cm}$ thick deformed diamicton layers (Fig. 15.3D). This sequence is underlain by a mixture of silt and sand with abundant dewatering and glaciotectonic deformation structures. Up to $0.5 \mathrm{~m}$ thick individual till beds are also found in the other parts of the sand pit. 

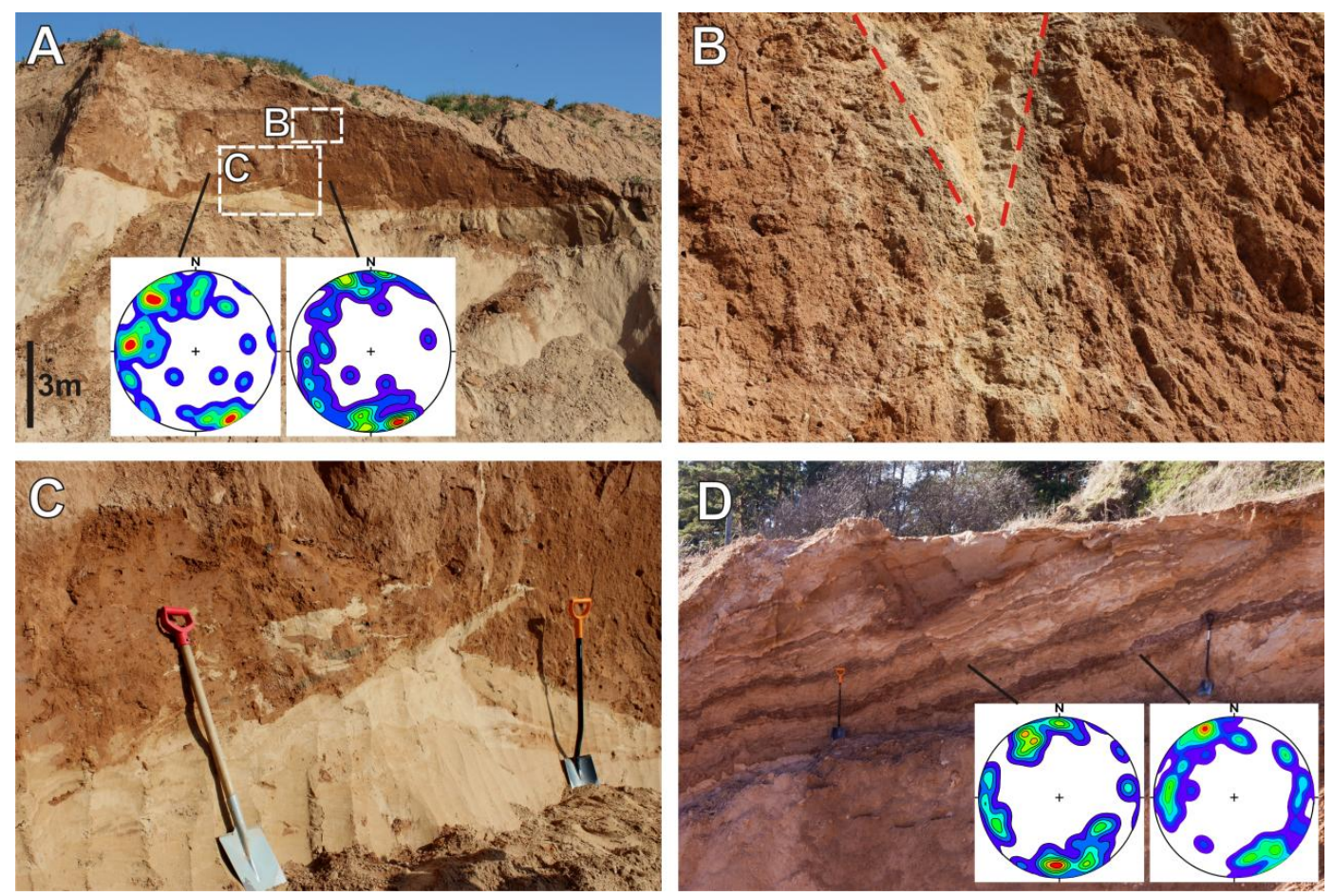

Fig. 15.3. Internal structure of the drumlin remnant in the Aizvējas sand pit: A. Outcrop consisting of 4-m-thick subglacial till underlain by deformed silt/sand sediments. B. Ice wedge pseudomorph in the upper part of the till; see location in Fig. 15.3A. C. Clastic dyke and sand inclusions in the lower part of the till; see location in Fig. 15.3A. D. Outcrop consisting of deformed silt and sand sediments intercalated with five deformed diamicton layers (up to $40 \mathrm{~cm}$ thick).

Till macrofabrics were measured at two spots in each of two outcrops (Fig. 15.3 A, D). All macrofabrics are multimodal but with a more expressed NNW-SSE trend, which corresponds to the regional ice flow movement, and additional maximums in three plots pointing to the west. It is most likely that the till fabric in these outcrops, too, especially in the second one (Fig. 15.3D), reflects a multiplex deformation pattern.

\section{References}

Dreimanis, A. 1935. The rock deformations, caused by inland ice, on the left bank of Daugava at Dole Island, near Riga in Latvia. Rīga, Gulbis, 30 pp. (In Latvian, with English summary)

Dreimanis, A., Zelčs, V. 1995. Pleistocene stratigraphy of Latvia. In: Ehlers, J., Kozarski, S., Gibbard, P. (eds.), Glacial Deposits in North-East Europe. Balkema, Rotterdam/Brookfield, pp. 105-113.

Lamsters, K. 2012. Drumlins and related glaciogenic landforms of the Madliena Tilted Plain, Central Latvian Lowland. Bulletin of the Geological Society of Finland, 84(1), 45-57.

Lamsters, K., Ošs, R. 2012. The distribution, morphology and internal structure of the Zemgale ribbed moraines, Central Latvian Lowland. In: Zelčs, V. (ed.-in chief), Acta Universitatis Latviensis. Earth and Environmental Sciences, 789. University of Latvia, pp. 52-65 (in Latvian, with English summary).

Naumenko, J., Jankins, J. 1999. Report on the results of the engineering and geological investigations of the perspective site „Mašēni” for the houshold and industrial waste dumpsite. SIA Geologiskais un geofiziskais centrs, Rīga, 78 pp. (In Latvian)

Stokes, C.R., Lian, O.B., Tulaczyk, S., Clark, C.D. 2008. Superimposition of ribbed moraines on a paleo-icestream bed: implications for ice stream dynamics and shutdown. Earth Surface Processes and Landforms, 33(4), 593-609.

Zelčs, V. 1993. Glaciotectonic landforms of divergent type glaciodepressional lowlands. Dissertation work synthesis. University of Latvia, Rīga, $105 \mathrm{pp}$.

Zelčs, V., Dreimanis, A. 1998. Daugmale ribbed moraine area: Introduction to STOP 1. Stop 1: Internal structure and morphology of glaciotectonic landforms at Daugmale. In: Zelčs, V. (ed.), Glacial Processes and Quaternary Environment in Latvia. Excursion guide of the INQUA Peribaltic Group Field Symposium, May 25-31, 1998, Rīga, Latvia. University of Latvia, Rīga, pp. 3-14. 


\title{
INQUA Peribaltic Regional Working Group Symposium Ratnieki Conference Center, August 19, 2014
}

\section{Oral and poster presentations}

\author{
ABSTRACTS
}




\section{PAPER AND POSTER SESSION PROGRAMME}

\section{Oral presentations}

09:00-09:20 Opening

Indriķis Muižnieks, Vice-rector, University of Latvia

Peter Johansson, Peribaltic Working Group President

09:20-09:40 Pertti Sarala and Vesa Peuraniemi: Extra short glacial transport mechanisms and application

09:40-10:00 Jacob Hardt and Margot Böse: Late Quaternary ice sheet dynamics in northeastern Germany - new insights in the formation of the Frankfurt ice marginal position based on the analysis of a high resolution LiDAR digital elevation model

10:00-10:20 Andrei Panin: Upper Dnieper River since LGM: ice damming, glacioisostatic effects and climatic forcing

10:20-10:40 A. J. (Tom) van Loon and Małgorzata Pisarska-Jamroży: Pleistocene glacio-isostatic seismites in NW Poland

Pause

11:00-11:20 Pille Lomp and Maris Rattas: Carbonate cements in glacial sediments: a palaeohydrologic indicator of glacial environment

11:20-11:40 Andreas Börner, Anna Hrynowiecka, Vladislav Kuznetsov and Renata Stachowicz-Rybka: Palaeoecological investigations and ${ }^{230} \mathrm{Th} / \mathrm{U}$ dating of Eemian interglacial peat sequence of Banzin, Mecklenburg-Western Pomerania, NE-Germany

11:40-12:00 Małgorzata Pisarska-Jamroży, A. J. (Tom) van Loon, Barbara Woronko and Beata Sternal: Heavy minerals as indicators of the source areas of the sediments in the Torun-Eberswalde ice-marginal valley, NW Poland

12:00-12:20 Edyta Kalińska-Nartiša, Māris Nartišs, Christine Thiel, Jan-Pieter Buylaert and Andrew Sean Murray: Application of the pulsed OSL in feldspar contaminated aeolian sediments: a case study of Eastern Latvia and Southern Estonia

Lunch 12:30

13:30-13:50 Alf Grube: Current issues of geological mapping in Schleswig-Holstein, Germany

13:50-14:10 Lyudmila P. Semenova, Andey V. Stepunin, Anton V. Maksimov and Tatyana I. Marchenko-Vagapova: Stratigraphy of Quaternary deposits, Sheet P-39 (Syktyvkar)

14:10-14:30 Nataliya Zaretskaya, Andrei Panin and Valeriy Shebotinov: MIS 2 alluvial terrace and the problem of the LGM proglacial lake in the River Vychegda valley, North-East Europe

14:30-14:50 Gretha Roelfs, Enno P. H. Bregman, Ilze Lūse, Mark Bakker, Harm J. Pierik, Florian W. H. Smit and Kim M. Cohen: The Late Saalian Hondsrug megaflute, Drenthe, The Netherlands: the base of an unique new European Geopark

14:50-15:10 A. J. (Tom) van Loon and Beata Gruszka: A giant loadcast resulting from ice re-advance over an esker near Ryssjön, South Sweden 


\section{Poster presentations and coffee 15:20-17:00}

Valery Astakhov, Valentina Shkatova, Andrei Zastrozhnov and Margarita Chuyko: Map of ice-marginal formations of European Russia

Valentinas Baltrūnas, Bronislavas Karmaza, Valentas Katinas, Vaida Šeirienè, Rimante Zinkute: Palaeoenvironmental changes and stratigraphy of Quaternary deposits of Lithuania

Dāvids Bērziņš and Jānis Karušs: Mapping shallow groundwater surface in terrigenous sediments using ground penetrating radar

Jānis Bikše, Konrāds Popovs, Aija Dēlinga and Alise Babre: Groundwater flow peculiarities induced by post-glacial and modern karst, Skaistkalne vicinity, Central Latvian plains

Enno P. H. Bregman: The EU Encore Fresh Water Project: from fundamental research towards practice

Aija Dēlina, Kristīne Dūdiña and Konrāds Popovs: Effect of buried valleys on groundwater flow: a case study in the vicinity of Ventspils, NW Latvia

Olga Druzhinina: New data on the palaeoenvironment of South-Eastern Baltic region: results of the scientific project RFBR 1205-33013

Laura Gedminienè, Gabrielè Rimkutè and Miglè Stančikaitè: Post-glacial environmental changes and the earliest human inhabitance of the Lake Dukštelis area, Eastern Lithuania

Alma Grigiene and Asta Jusiene: Development of the Plateliai area in Late Weichselian and Holocene, NW Lithuania

Peter Johansson, Yury Voytekhovsky, Laura S. Lauri and Jouni Pihlaja: ABCGheritage project - geological cooperation in northern Fennoscandia

Katrin Kalla and Tiit Hang: Deglacial ice dynamics in Estonia as derived from glacial bedforms

Danguole Karmaziene: Morphogenetic classification of kame terraces in the Late Nemunas glaciation area of Lithuania

Denis Kuznetsov, Anna Ludikova and Tatyana Sapelko: The isolation stratigraphy of small lakes in northern Lake Ladoga basin in reconstructions of the Baltic Ice Lake final stage and early Holocene glacioisostatic uplift

Kristaps Lamsters and Jānis Karušs: Glacial landforms in the forefield of Múlajökull surge-type glacier, Central Iceland

Anna Ludikova: The diatoms of the Baltic Ice Lake: new data from the Lake Ladoga region, the easternmost part of the Baltic Ice Lake

Agnese Pujāte, Karina Stankeviča, Anda Dručka, Anda Staškova, Aija Ceriņa, Laimdota Kalniņa and Elīza Kuškse: Records of natural and human-induced environmental changes in Latvian lake sediments

Violeta Pukelyte: The links between Quaternary palaeosurfaces and present surface of South Lithuania

Inga Retiķe, Jānis Bikše, Andis Kalvāns, Alise Babre, Gunta Kalvāne and Konrāds Popovs: Chemical characterization of Quaternary groundwaters in Latvia: a case study of trace element content

Eugenija Rudnickaité and Rimantè Guobyte: Lithological variability in tills of the Samogitian Upland and surrounding area, Lithuania

Leili Saarse: Cyclic sedimentation pattern in the Lake Veetka, SE Estonia 
Pertti Sarala: Low-impact exploration methods promoting the Green Mining concept in Finland

Anda Staškova, Aija Ceriņa, Agnese Pujāte and Laimdota Kalniņa: Palaeovegetation changes recorded by macroscopic fossil investigation data from Lake Ummis and Lake Mazais Ungurs sediments, Latvia

Eriks Tabuns, Kathrine Kuksa, Mikhail Nikitin, Snezhana Levchenko, Alex Petrov and Vasiliy Grigoriev: Freshwater travertine from NW Russia - terrestrial archives of paleoenvironmental information

Giedrè Vaikutienè, Raminta Skipitytè, Jonas Mažeika, Tõnu Martma, Andrius Garbaras and Rüta Barisevičiuté: Investigation of stable isotopes and diatom assemblages - a key for paleoenvironmental reconstruction, Curonian Lagoon, Lithuania 


\title{
Map of ice-marginal formations of European Russia
}

\author{
Valery Astakhov a,b ${ }^{\mathrm{a}}$ Valentina Shkatova ${ }^{\mathrm{a}}$, Andrei Zastrozhnov ${ }^{\mathrm{a}}$ and Margarita Chuyko ${ }^{\mathrm{a}}$ \\ ${ }^{a}$ A.P.Karpinsky Russian Geological Research Institute (VSEGEI), Russsia \\ ${ }^{\mathrm{b}}$ St. Petersburg State University, Russia
}

Compiling the Quaternary map of the Russian Federation on a scale of 1:2,500,000 we had to struggle with the fundamental problem of stratigraphic correlation of genetically various sedimentary formations between numerous regions of northern Eurasia. To partly resolve this problem for glaciated terrains interregional tracing of surficial ice-marginal formations has been undertaken. For primary database we used published (or in press) sheets of the National Geological Map of the Russian Federation on a scale of 1:1,000,000. The necessary information is contained in Quaternary maps which are prescribed as obligatory for each quadrangle $4^{\circ} \times 6^{\circ}$ of the National Map. Sheets of the third generation in the GIS-format issued in 2009-2013 are part of the ready-map series. The other part of the series employed in our work is analogue maps of the $2^{\text {nd }}$ generation published between 1979 and 2002.

For interregional correlation of the ice marginal complexes we used satellite images and recent publications on Quaternary stratigraphy of northern terrains. A wealth of valuable data has been provided by international cooperative works in the Arctic under the aegis of European Science Foundation coordination programs QUEEN and APEX, by RussianNorwegian, Russian-German and Swedish-American projects. Useful information on interregional correlation of ice margins is contained in the INQUA compendium on glacial features of the world (Astakhov 2011; Velichko et al. 2011). The digital maps of this edition available on the Web in scale 1:1,000,000 are less detailed than the standard Quaternary sheets of Russia but the interpolations suggested therein can be used for filling inavoidable gaps in the general pattern of ice margins of this formidable territory.

The result of our work is the Glaciomorphological Map of the Russian Federation on a scale of 1:2,500,000 in GIS-format. Here we present the European part of the map (including the Urals) picturing ice marginal formations 600 to $11 \mathrm{ka}$ old. The major features of the map are limits of topographically expressed and stratigraphically proven independent glacial stages: D - the Don glaciation (approx. MIS 16), S - the Moscow glaciation (Saale), $\mathrm{W}_{1}$ - the early Weichselian glaciation (ca 80-90 ka BP), $\mathrm{W}_{2}$ - the Middle Weichselian glaciation (ca 50-60 ka BP), $\mathrm{W}_{3}$ - the Late Weichselian glaciation (the classical Valdai, ca 30-10 ka BP).

Minor ice limits within the area of the last Scandinavan glaciation, irrespective of their stratigraphic significance, are drawn by geomorphic reasoning along subparallel marginal belts to mark positions of the retreating ice margin within the time span of 20 to $11 \mathrm{ka} \mathrm{BP}$. West of the Russian border they are called either glacial phases (in Poland) or ice-marginal zones (Kalm 2012). In Russia they were originally mapped and named in the 1960-s but in those times called 'stages` (Zarrina and Krasnov 1965) which is confusing because no significant glacier readvances were ever proven along such lines. However, these marginal lines are useful for correlation of the Valdai glacial history with better dated late glacial events in Europe. Kalm (2012) already tried to connect the Baltic ice-marginal zones with their Russian counterparts. We followed suit with minor revisions based on recent geological mapping data.

The presented map also shows other features presumably related to or elucidating the structure of ice marginal zones. They are hummock and ridge landscapes, kame plateaus, drumlins, individual large morainic ridges and kames, detached sedimentary megablocks, outstanding glacial disturbances, ice-contact lines and huge erratics. Also, major interpretation 
results such as ice flow directions and ice stream axes are shown. We hope that this map will be helpful in sorting out the history of former ice sheets in the southeastern sector of the Scandinavian glaciation and their relation with northeastern ice sheets. E.g., the minuscule Late Pleistocene alpine moraines of the Urals underline the negligible role of this mountain range as an ice dispersal center. The pattern of older ice limits suggests that they were considerably influenced by mighty sources of inland ice on the arctic shelves.

\title{
References
}

Astakhov, V. 2011. Ice margins of northern Russia revisited. In: Ehlers, J., Gibbard, P.L., Hughes, P.D. (eds.), Quaternary glaciations - extent and chronology: a closer look. Developments in Quaternary Science, 15. Elsevier, Amsterdam, pp. 323-336.

Kalm, V. 2012. Ice-flow pattern and extent of the last Scandinavian Ice Sheet southeast of the Baltic Sea. Quaternary Science Reviews, 44, 51-59.

Velichko, A.A., Faustova, M.A., Gribchenko, Y.N., Pisareva, V.V., Sudakova, N.G. 2011. Glaciations of the East European Plain: distribution and chronology. In: Ehlers, J., Gibbard, P.L., Hughes, P.D. (eds.), Quaternary glaciations - extent and chronology: a closer look. Developments in Quaternary Science, 15. Elsevier, Amsterdam, pp. 337-359.

Zarrina, Y.P., Krasnov, I.I. 1965. The problem of correlation of ice marginal belts in the northwestern European USSR and adjacent foreign areas. In: Krayevye obrazovania materikovykh oledeneniy. Mintis, Vilnius, pp. 5-21 (in Russian).

\section{Palaeoenvironmental changes and stratigraphy of Quaternary deposits of Lithuania}

\author{
Valentinas Baltrūnas, Bronislavas Karmaza, Valentas Katinas, Vaida Šeirienė and \\ Rimante Zinkute
}

Institute of Geology and Geography, Nature Research Centre, Lithuania

During the period from 2012 to 2013 sediments from Quaternary warm intervals were studied by complex proxies (geochemical, palaeomagnetic, magnetic susceptibility and anisotropy of magnetic susceptibility) to establish the cyclicity and dynamics of palaeoenvironmental changes. This interdisciplinary approach enabled the subdivision of the sections into stratigraphic units as well. Studies were concentrated on five sections Daumantai, Šlavė, Butėnai, Snaigupèlè and Netiesos outcrops, Jononys-938 and Snaigupèlè705 boreholes, representing different interglacials.

The results of the palaeomagnetic investigations and the detection of the boundary of the Brunhes/Matuyama inversion in Daumantai sections enable the subdivision of the sediments to the Early, Middle and Late Pleistocene and correction of the position of Early/Middle Pleistocene boundary (Baltrūnas et al. 2013a). In the section Daumantai-1, the distinctly expressed lithological and textural boundary fixates the Neogene (Pliocene)/Quaternary (Pleistocene) boundary, which is proved by the palaeobotanical data, too. The determination of those two boundaries capacitates the correlation of the sediments studied with MIS 19 (760-787 ka; Brunhes/Matuyama boundary is $780 \mathrm{ka}$ ). Below of the Brunhes/Matuyama boundary in the Daumantai-1 section and above the Jaramillo subchron (0.99-1.07 Ma) which was traced in the Daumantai-3 section, the MIS 20-31 sediments could be expected, but the process of identifying those is incomplete.

Based on palaeomagnetic data, the lacustrine sediments of the Šlavè-2 outcrop were slowly deposited by sediment derivation from the west during the Early Pleistocene and may be attributed to the palaeomagnetic Matuyama Chron (Baltrūnas et al. 2013b). The lower part of the section is distinguished by a mixed polarity zone which belongs to the Jaramillo subchron. 
Geochemical peculiarities of the Vindžiūnai-136 section, representing the Vindžiūnai Interglacial of the Middle Pleistocene, are determined by the proportion of terrigenous and authigenic components, the biogenic component being less important.

The Kudrè-915 section, which represents the Turgeliai Interglacial (Middle Pleistocene), differs greatly from the other two (Šlavė and Vindžiūnai) sections. The Kudre palaeolake was dominated by authigenic sedimentation. The highest median TOC value $(3.89 \%)$ shows the influence of biogenic component (Baltrūnas et al. 2014). The palaeoflora in the deposits indicates that the Turgeliai Interglacial was warmer than the Vindžiūnai interglacial. The older age of the Vindžiūnai Interglacial is suggested by abundance of fossil Pliocene species and by species which were present in Northern and Eastern Europe only in the Early Pleistocene. These first Middle Pleistocene interglacials can be attributed to the coolest ones marked by weaker biogenic sedimentation.

In the sections of the Jononys-938 borehole and Butenai outcrop representing the Butėnai (Holsteinian) Interglacial dominate authigenic-biogenic and terrigenous components. Palaeomagnetic investigations showed that the sediments of the Butenai outcrop were orientated by normal magnetic polarity and correlated with MIS 11 .

The Snaigupèlè Interglacial (Middle Pleistocene) deposits in Snaigupèlè outcrop and Snaigupèle-705 borehole are marked for different bedding conditions nevertheless the sections are located closely to each other. In the borehole the interglacial deposits are thicker and occur much deeper than the analogous deposits in the outcrop. Palaeomagnetic investigations ascertained that the layers of lacustrine sediments in the lower part of the Snaigupele outcrop were orientated by reversed magnetic excursion and in the upper part by normal magnetic polarity. Correlation of the obtained data with the global geomagnetic scale defined that the palaeomagnetic inversion observed in the Snaigupele section could be related with the Blake event in the Eemian interglacial.

Comparison of the magnitudes and distribution pattern of the scores of minerogenic (allogenic), authigenic and biogenic factors determined according to geochemical data from 29 chemical elements in the Netiesos section (Merkinè (Eemian) Interglacial), enabled the distinguishing of 14 depth-related geochemical units (U1-U14), reflecting changes of sedimentation environment from the inherited glaciolacustrine up to eutrophic lake with considerable water level changes (Baltrūnas et al. 2013b). Parallel geomagnetic and ESR geochronological research capacitates to identify the palaeomagnetic Blake Event in the gyttja layer ESR dated at about $112 \mathrm{ka}$. This could be correlated with the beginning of the climatic optimum of the Eemian interglacial (spread of Quercus,Ulmus, Corylus, Pinus). The sediments overlying the Eemian interglacial layers according to IR-OSL data, lithological and geochemical investigations implies deposition during MIS 2-4.

The authors are grateful to the Research Council of Lithuania for their financial support of the project "Ciklas" (reg. No LEK-12007, agreement No LEK-06/2012).

\section{References}

Baltrūnas, V., Zinkute, R., Šeirienè, V., Katinas, V., Karmaza, B., Kisielienė, D., Taraškevičius, R., Lagunavičienè, L. 2013a. Sedimentary environment changes during the Early-Middle Pleistocene transition as recorded by the Daumantai sections in Lithuania. Geological Quarterly, 57 (1), 45-60.

Baltrūnas, V., Šeirienè, V., Molodkov, A., Zinkutè, R., Katinas, V., Karmaza, B., Kisielienè, D., Petrošius, R., Taraškevičius, R., Piličiauskas, G., Schmölcke, U., Heinrich, D. 2013b. Depositional environment and climate changes during the late Pleistocene as recorded by the Netiesos section in southern Lithuania. Quaternary International, 292, 136-149.

Baltrūnas, V., Zinkutė, R., Šeirienè, V., Karmaza, B., Katinas, V., Kisielienè, D., Stakènienė, R., Pukelytė, V. 2014. The earliest Pleistocene interglacials in Lithuania in the context of global environmental change. Geological Quarterly 58 (1), 45-59, doi: 10.7306/gq.1148. 


\section{Mapping shallow groundwater surface in terrigenous sediments using ground penetrating radar}

Dāvids Bērziņš and Jānis Karušs

University of Latvia

Results of several studies have shown that mapping shallow groundwater table with ground penetrating radar (GPR) is relatively easy, especially in terrigenous sediments such as aeolian dune sands, due to big contrast in relative dielectric permittivity between dry sand above and saturated sand beneath the water table (Bristow 2009). Nevertheless some studies show that it is ambiguous due to capillary fringe (Bentley and Trenholm 2002).

This research analyses possibilities of mapping groundwater surface in terrigenous sandy sediments using GPR. Near surface geophysical measurements using GPR method was done in October 2013 in Latvia, approximately $10 \mathrm{~km}$ NE of Strenči, using SIA Radar systems manufactured radar Zond-12e with three compatible antenna systems of $100 \mathrm{MHz}, 300 \mathrm{MHz}$ un $500 \mathrm{MHz}$. GPR surveying profile were oriented SW on forest footpath across linear dune, GPR profiling were done twice with each antenna system. Overall profile length was 361 meters and topography was measured with leveler Geomark $A K-32$. To correlate GPR signals with physical properties of sediments, four test boreholes were installed. Groundwater table were recognized in the boreholes, also soil samples for further laboratory analysis were taken. Soil samples were analyzed in laboratory for natural moisture using heating technique in $105 \mathrm{C}^{\circ}$ temperatures and grain size distribution. Electromagnetic wave propagation speed in sediments was determined with common midpoint method, using $300 \mathrm{MHz}$ antenna as a transmitter and $500 \mathrm{MHz}$ antenna as a receiver (Bristow and Jol 2003). Obtained GPR radargrams were processed with envelope filter (Fig. 1). Depth, which three informative signals were received from, was determined. And as a result it was possible to correlate obtained GPR signals to changes of physical properties of sediments (Figs. 1 and 2).

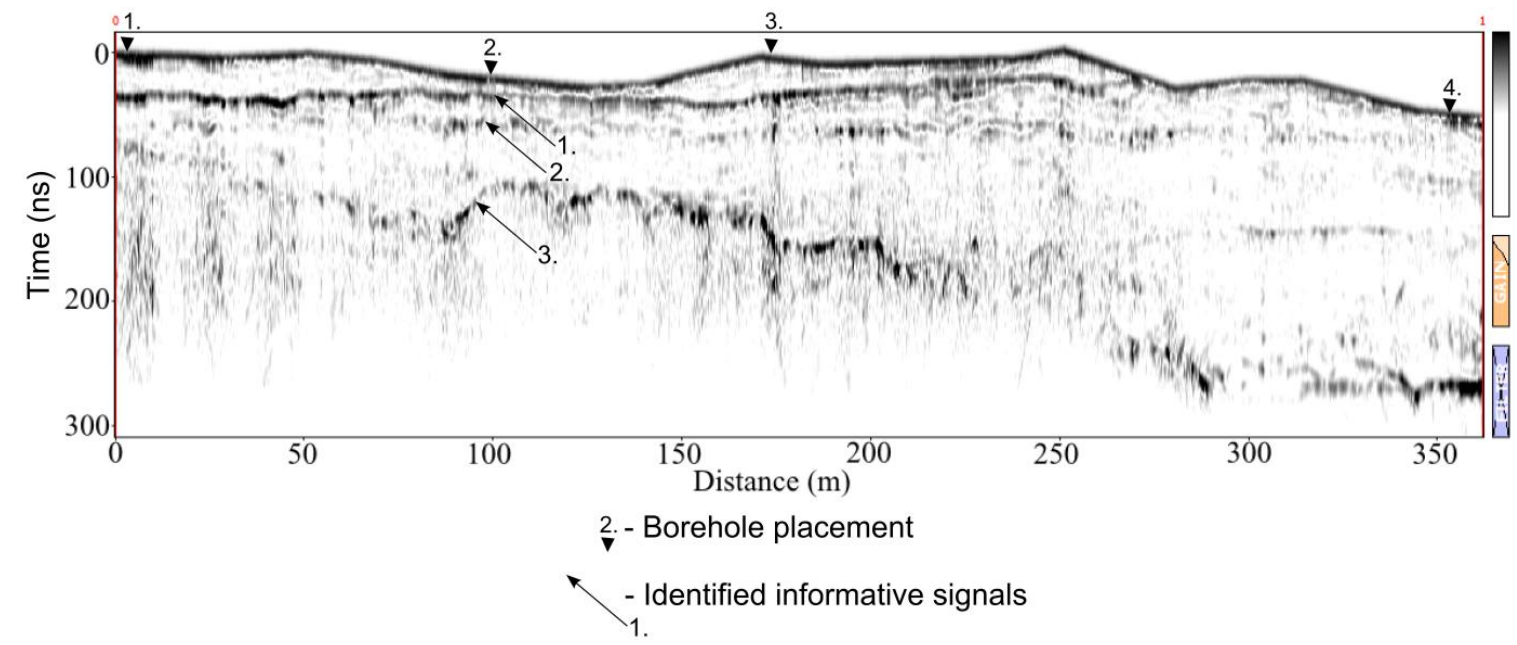

Fig. 1. GPR profile obtained with $300 \mathrm{MHz}$ antenna.

Soil analysis for grain size distribution confirmed that sand is fine-grained, well sorted with minimal varieties of silt except for a $10-15 \mathrm{~cm}$ thick layer with increased silt values at a depth of approximately $1 \mathrm{~m}$ at location of borehole No. 2. Analyses for natural moisture determined that moisture is gradually increasing downwards in half meter long zone above the water table (Fig. 2). 


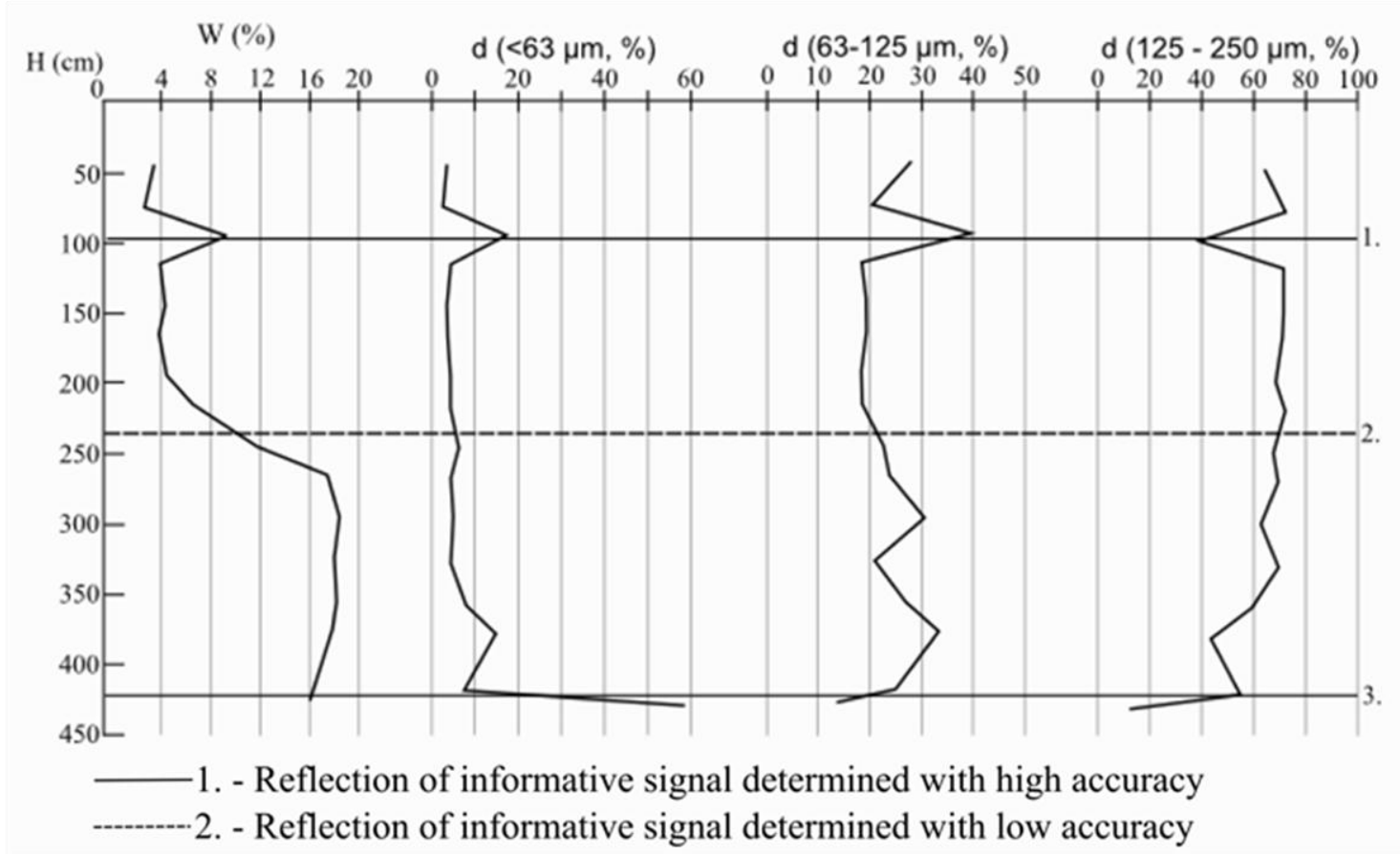

Fig. 2. Moisture and granulometric changes in borehole No. 2.

Although results show that signal reflection mainly occurs due to changes of soil moisture content (Fig 2: signals No. 1 and 2), but reflection of signal No. 3 appears due to granulometric changes on border between sand and till.

Results of this study show that identifying shallow groundwater table in sandy terrigenous sediments using GPR is ambiguous. Signal reflection occurs in the middle part of the capillary fringe. As a result precision with which it is possible to determine a depth of the water table depends on a height of the capillary fringe. Following studies should pay attention to effect of the capillary fringe on GPR's produced reflections.

\section{Literature:}

Bentley, L.R., Trenholm, N.M. 2002. The accuracy of water tabele elevation estimates determined from ground penetrating radar data. Journal of Enivronmental and Engenering Geophysics, 7(1), 37-53.

Bristow, C.S. 2009. Ground penetrating radar in aeolian dune sands. In: Jol, H.M. (ed.), Ground Penetrating Radar: theory and applications. Elsevier Science, p. 273-297.

Bristow, C.S., Jol, H.M. 2003. An introduction to ground penetrating radar (GPR) in sediments. In: Bristow, C.S., Jol, H.M. (eds.), Ground Penetrating Radar in Sediments. Geological Society Special Publication, 211, pp. 1-7.

\section{Groundwater flow peculiarities induced by post-glacial and modern karst, Skaistkalne vicinity, Central Latvian plains}

Jānis Bikše, Konrāds Popovs, Aija Dēliņa and Alise Babre

University of Latvia, Latvia

Quaternary karst environments often have complicated groundwater flow system because of sinkholes and underground conduits. It is complex task to understand groundwater flow pattern in such conditions. Therefore several approaches need to be used in order to determine groundwater flow regime and specific underground connections. The Skaistkalne vicinity is excellent place where investigate groundwater peculiarities induced by post-glacial 
and modern karst features, like sinkholes of different shapes and ages, and underground conduits. Two rivers - Mēmele and Iecava make this place more complex because of their close location $(2.6 \mathrm{~km})$ and significant water level differences (up to 7 metres). Tracer test experiment was conducted, and numerical model was created to understand groundwater flow peculiarities in the research area.

Quaternary karst processes have affected Upper Devonian gypsum and carbonaceous rocks covered by the Late Weichselian till and glaciofluvial deposits. Pleistocene deposits are low to high permeable, vary in thickness from $5 \mathrm{~m}$ to $25 \mathrm{~m}$. Quaternary sediments are separated from Upper Devonian Salaspils formation by very low permeable clay layer and till. Therefore Salaspils formation has confined aquifer conditions although surface water from the River Iecava and sinkholes might intrude at some degree. Connection between Iecava and Memele rivers was investigated by tracer test yielded out at medium-level water conditions. 600 grams of fluorescent colour were injected into the River Iecava about $1 \mathrm{~km}$ upstream from potential leakage area. Several wells were observed by fluorometer and by sampling in order to detect traces of colour. Tracer test results showed that conduits characterized by high permeability connect rivers and karst lakes, and groundwater velocity reaches $800-1300$ $\mathrm{m} /$ day there. Concentration profile of recovered fluorescent dye implies complicated groundwater channel system characterized by inter-connected conduits.

Numerical model for research area was created by applying all available geological information combined with results from tracer test. New technique called honey-comb structure was implied in model in order to simulate karst environment. All known Quaternary sinkholes were included in model as well as both rivers and underlying Upper Pleistocene and Holocene alluvial sediments. Model yielded good results as it fitted well with observed water levels in monitoring wells. Numerical model showed that post-glacial karst processes has influence on groundwater flow distribution caused by sinkholes and developed underground conduits. The best model results were observed when horizontal hydraulic conductivity for gypsum conduits in honey-comb structure was set to $570 \mathrm{~m} /$ day. In research area groundwater flow regime is greatly influenced by post-glacial karst processes. The River Iecava has connection to groundwater therefore river water favours karst process activity until today.

This study is supported by the European Regional Development Fund project Nr.2013/0054/2DP/2.1.1.1.0/13/APIA/VIAA/007 in Latvia.

\section{Palaeoecological investigations and ${ }^{230} \mathrm{Th} / \mathrm{U}$ dating of Eemian interglacial peat sequence of Banzin, Mecklenburg-Western Pomerania, NE Germany}

Andreas Börner ${ }^{\mathrm{a}}$, Anna Hrynowiecka ${ }^{\mathrm{b}}$, Vladislav Kuznetsov ${ }^{\mathrm{c}}$, Renata Stachowicz-Rybka ${ }^{\mathrm{d}}$, Fedor Maksimov $^{c}$, Vasily Grigoriev ${ }^{c}$, Monika Niska ${ }^{\mathrm{e}}$ and Magdalena Moskal-del Hoyo ${ }^{\mathrm{d}}$

\footnotetext{
${ }^{\mathrm{a}}$ State authority for Environment, Nature protection and Geology of Mecklenburg-Vorpommern, State Geological Survey, Germany

${ }^{\mathrm{b}}$ Polish Geological Institute, Poland

c Saint-Petersburg State University, Russia

${ }^{\mathrm{d}}$ Polish Academy of Science, Institute of Botany PAS, Poland

e Pomeranian University in Stupsk, Poland
}

The following summary based on scientific co-operative agreement of the Peribaltic group conference 2012 that first publication now is in submission (Börner et al. in review). A buried peat sequence was found in 2011 in a short-lived outcrop of pipeline trench in SW 
Mecklenburg near the village Banzin, $15 \mathrm{~km} \mathrm{~W}$ of the town Hagenow. The profiles are situated in a shallow kettle hole in the undulated landscape of the Saalian glaciation (Fig. 1). The till samples from the upper till complex from neighbouring profiles shows a typical Saalian till gravel composition. The assemblages of regional till samples comprise a high percentage of Palaeozoic limestone and are relatively rich in dolomite but yet poor in sandstone. The distribution of this typical lithofacies occurs in both Saalian (Drenthe and Warthe) tills and reflects the regional trend of the Saalian till distribution close to the surface.

The main sequence of the Banzin profiles is exemplary for the development of a basin during the Late Saalian deglaciation, which is characterised by glaciolimnic deposits at the basement. Only on the basin edges glaciolimnic deposits are disturbed by gravity faults with

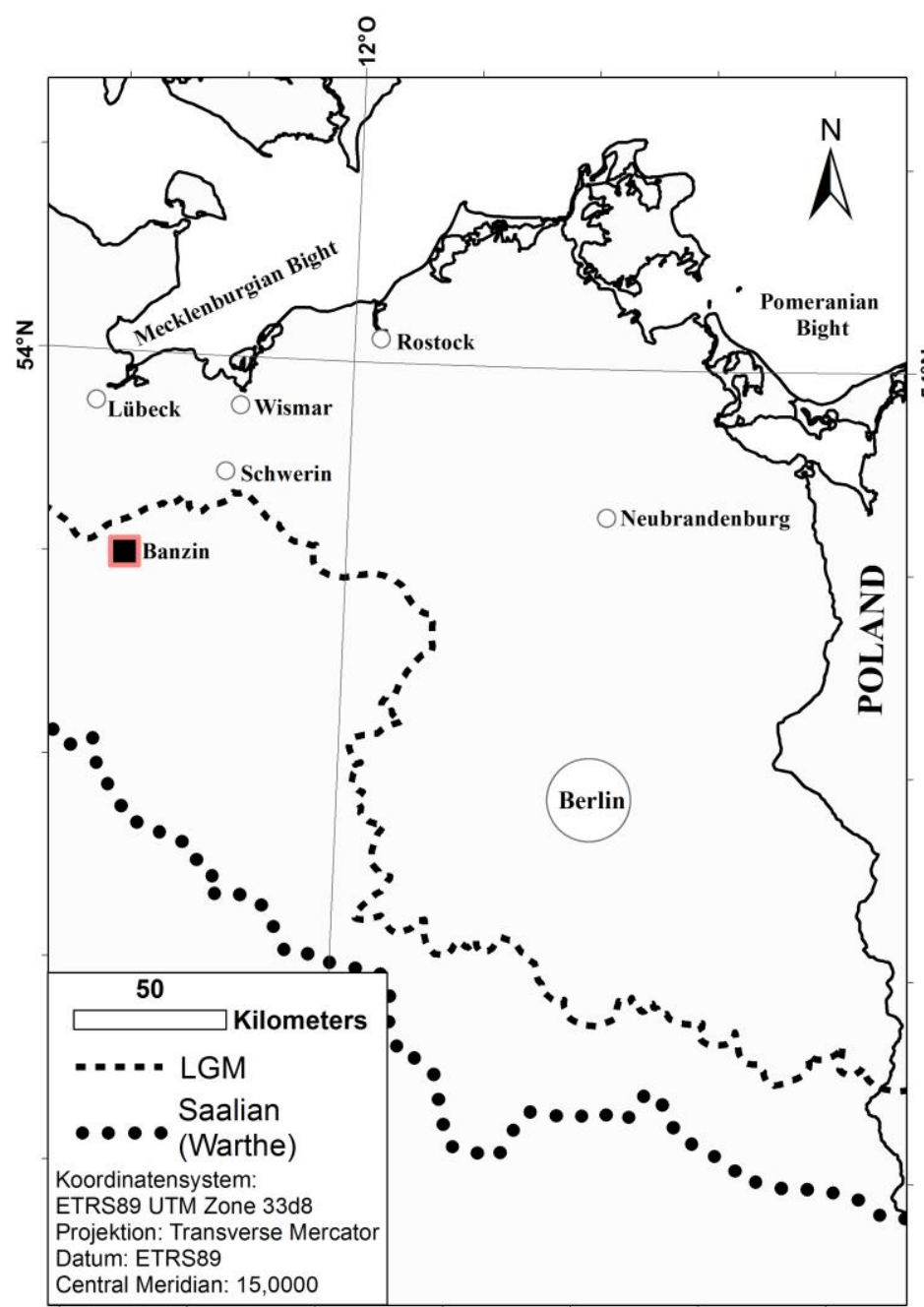

Fig. 1. Location of the study area. reversal dipping. This gravity faults are related to melt down of shallow dead ice bodies adjoining to the glaciolimnic deposits and support the kettle holes origin of the Banzin basin related to decreasing permafrost conditions of Late Saalian time. In the Banzin kettle at a depth of $2.2 \mathrm{~m}$ lays a $0.5 \mathrm{~m}$ strongly compressed Eemian peat layer.

The investigated sequence started in the Late Saalian (MIS 6) in a landscape where herbaceous vegetation and heliophytes were common. Start of Eemian interglacial (MIS 5e) is a typical dominance of light birch forests followed pine. The optimum climate was characterized by encroachment oak forests and then hazel-oak forest and during this phase ended the sedimentation in the reservoir of Banzin. In the late Saalian, shallow waters of the basin most likely attained a depth below $3 \mathrm{~m}$ and were abundant in calcium carbonate. Banzin-I and Banzin-II profiles appear to bear a record of a shallow lacustrine basin with water more abundant in calcium carbonate at the close of the Late Saalian glaciation, as evidenced by the presence of fruits of Cladium mariscus. This species, considered as an indicator of climatic optima during interglacials, also occurs in cooler periods, during which it usually compensates lower temperatures with increased calcium carbonate uptake. At the beginning of the Eemian interglacial, as temperature conditions improved and lake trophy increased, water level in the basin gradually decreased as it was filled in with coarse-detritus gyttja sediments. The climatic optimum enabled growth of taxa with higher temperature requirements such as Ceratophyllum submersum, Aldrovanda vesiculosa and cf. Dulichium sp. Both palynological data, marked by the disappearance of pollen of aquatic plants, and the composition of peat vegetation deduced from seeds and 
fruits, indicate development of a peat bog (resembling a low-level peat bog) from the beginning of PZ IVa. The vegetation of climate optimum was characterized by encroachment oak forest and then hazel-oak forest - this phase ended the sedimentation in the Banzin reservoir. Younger Eemian peat have not been preserved, probably (1) caused by proceeding terrestrialisation of the uppermost bog above the limited groundwater table and (2) by subsequent erosional processes during Weichselian periglacial conditions.

The first results samples from peat bog layers in NE Germany are obtained by mean of 230Th/U dating by leachate alone (L/L) and total sample dissolution (TSD) analytical techniques. Isochronously corrected $230 \mathrm{Th} / \mathrm{U}$ ages of $117.6 \pm 9.7 / 7.9 \mathrm{ka}(\mathrm{L} / \mathrm{L})$ and $121.3 \pm$ 11.9/9.3 ka (TSD) were obtained. Both $230 \mathrm{Th} / \mathrm{U}$ dates $\sim 120 \mathrm{ka}$ obtained using two different techniques confirm the biostratigraphical classification into the Eemian interglacial within MIS 5e. The overlaying unit corresponds to colluvisol deposits of periglacial gelifluction and solifluction origin. The Eemian peat layer is locally interrupted by ice wedge pseudomorph structures, up to mega-crack structures $>0.5 \mathrm{~m}$ and involutions which document a strong periglacial influence during the Weichselian stadial phases. The top of the Banzin sequence is covered by a $0.5 \mathrm{~m}$ thick colluvisol layer of redeposited humic loam of Late Weichselian/Holocene. The uppermost unit suggests solifluction processes likely caused by the intensive anthropogenic influence during the last few hundred years. The geological and palaeoecological results in good agreement with the new ${ }^{230} \mathrm{Th} / \mathrm{U}$ data fit very well into the general stratigraphic classification and illustrate development of the kettle hole after the Saalian deglaciation.

The Cladocera analysis was supported by the Foundation for Polish Science, Bridge Program BIS/2012-5/1. The macroremais analysis was financed by the W. Szafer Institute of Botany, Polish Academy of Sciences from its statutory funds. The U/Th analysis was partially supported by the Russian Foundation for Basic Research (Projects No 13-05-00854, 14-0531511 and 14-05-31448).

\title{
Reference
}

Börner, A., Hrynowiecka, A., Stachowicz-Rybka, R., Kuznetsov, V., Maksimov, F., Grigoriev, V, Niska, M., Moskal-del Hoyo, M. (in review). Palaeoecological investigations and ${ }^{230} \mathrm{Th} / \mathrm{U}$ dating of Eemian interglacial peat sequence of Banzin (Mecklenburg-Western Pomerania, NE-Germany. Submitted in Quaternary International.

\section{The EU Encore Fresh Water Project: from fundamental research towards practice}

\author{
Enno P. H. Bregman ${ }^{\mathrm{ab}}$ \\ ${ }^{\mathrm{a}}$ Utrecht University, the Netherlands \\ ${ }^{\mathrm{b}}$ Province of Drenthe, the Netherlands
}

Outcome of deep and shallow groundwater flow modelling resulted in the insight that in a geological setting of Permian Zechstein salt domes Glacial Buried Valley's (GBV's) play and important role in flow characteristics and because of double diffuse convection also on groundwater quality. In the brook valley system of the Nutch National Park de Drentsche Aa we could explain the relevance of this knowledge for nature and landscape management as well as on other functions. We could calibrate our models with vegetation, especially deep seepage indicating plant species. So we got not only more insight in the interaction of deep and shallow groundwater systems and impact of geological features (positioning of salt domes as well as impact of fault structures on groundwater), but once running the models we could 
also simulate impact of groundwater extraction and Underground Thermal Energy Storage (UTES). At this way we got more insight in the actual and potential meaning of GBV's for different functions as well as sensibility of the groundwater system, too. In the Northern part of the Netherlands as well as in Northern Europe GBV's provide millions of people and food industries of fresh drinking water.

As a reference of our outcome we made an overview of GBV's in the European ice marginal zone on land (from the Netherlands to Russia) with focus on positioning, knowledge about infillings, threats and regional and national governmental policy to protect the fresh water bodies in GBV's. Main conclusion is that there are huge gaps in knowledge, threats are everywhere, and in regions and countries awareness and structural protection are missing. In 2012 Province of Drenthe had the chair of a political meeting of the ENvironmental COoperation of European Regions, ENCORE. The meeting decided to start an Alliance on Fresh Water. Finally 15 organisations from 7 countries presented in 2014 in the 2014 ENCORE conference in Munich a European programme to improve in different actions, like a Mapping and Monitoring Project, and an international Project New Agriculture to reduce diffuse pollution. The program costs at least 17 million and has agreement on the political level of EU and Regions as well. We created on base of fundamental knowledge a program with opportunities for scientist to exchange knowledge, new $\mathrm{PhD}$ positions, to develop for example a standardized EU monitoring programme and work out and share knowledge about modelling as a base for governments who will take steps now to improve groundwater protection policy as well.

\section{Reference}

Bregman, E.P.H., de Vree, L., Smilt, L., Anneweldt, J. 2014. Encore Results Alliance Fresh Water Project. Province of Drenthe, $91 \mathrm{pp}$.

\section{The Late Saalian Hondsrug megaflute, Drenthe, the Netherlands: the base of an unique new European Geopark}

Enno P. H. Bregman ${ }^{\mathrm{a}, \mathrm{b}, \mathrm{c}}$, Ilze Lūse ${ }^{\mathrm{d}}$, Mark Bakker $^{\mathrm{e}}$, Harm J. Pierik ${ }^{\mathrm{a}}$, Florian W. H. Smit ${ }^{\mathrm{f}}$ and Kim M. Cohen ${ }^{\text {aeg }}$

\footnotetext{
${ }^{\mathrm{a}}$ Utrecht University, the Netherland

${ }^{\mathrm{b}}$ Province of Drenthe, the Netherlands

${ }^{\mathrm{c}}$ I.Kant Baltic Federal State University, Russia

${ }^{\mathrm{d}}$ Latvia University of Agriculture, Latvia

${ }^{\mathrm{e}}$ Deltares, Utrecht, the Netherlands

f Aarhus University, Denmark

${ }^{\mathrm{g}}$ TNO, Utrecht, the Netherlands
}

Ice streams always reflect an unbalance between accumulation and ablation in ice sheets. Along ice sheet margins they are highly variable and dynamic in space and time. Present-day and Last Glacial examples of ice streams demonstrate a behaviour of switching on and off, acceleration and deceleration, migration and change of direction. The situation at the ice margin provides a main control on the mass (in)balance of the ice stream, for example where melting or calving occurs in ice lakes, seas and oceans. Knowledge on controlling factors and process dynamics of present day ice streams has much grown. For palaeo-ice streams, however less studies truly assess process-relations, especially in NW Europe. We 
have focussed on the Hondsrug-Hümmling ice stream of Saalian age (Drenthe Substage, within MIS 6) in NE Netherlands and NW Germany, glaciated in the penultimate glacial, but not in the last glacial. The best expression is a $70 \mathrm{~km}$ long mega flute complex landform, known as 'Hondsrug' (e.g. Rappol, 1984; Van den Berg and Beets, 1987). Because of its unique genesis and preservation, the Province of Drenthe has nominated the Hondsrug to apply to be a European Geopark.

We have importantly updated the reconstruction of phases of the glaciation for the wider region and have collected new data on the palaeo-ice stream using road-cut outcrops, boreholes, seismics and ground penetrating radar and "new" till characterisation techniques (XRPD analyses of clay minerals).

Results are discussed and related to Winsborrow et al. (2010) hierarchy of controls of ice streams. We have strong reasons that ice streams of the terrestrial ice margins of the former Scandinavian ice sheets of the North Sea, German, Polish and Baltic area are controlled in a different way than e.g. Antarctic actuo-examles and North American palaeoexamples. The ice-streams appear regional initial deglaciation phenomena, affected by substrate and ice-margin control primarily, rather than larger scale expanding ice-cap phenomena. This conclusion opens a new approach in understanding the scales and dynamics of ice streaming at the tipping point of maximum glaciation to initial deglaciation, and input for further research between the North Sea and the Baltic.

\section{References}

Bregman, E.P.H., Smit, F.W.H. 2012. Genesis of the Hondsrug a saalian megaflute, Drenthe, the Netherlands. Utrecht University, $123 \mathrm{pp}$.

Rappol, M. 1984. Till in Southeast Drente and the origin of the Hondsrug complex, the Netherlands. Eiszeitalter und Gegenwart, 34, 7-27

Van den Berg, M.W., Beets, D.J. 1987. Saalian glacial deposits and morphology in the Netherlands. In: Van der Meer, J.J.M. (ed), Tills and Glaciotectonics. Balkema, Rotterdam, pp. 235-251.

Winsborrow, M.C.M., Clark, C.D., Stokes, C.R. 2010. What controls the location of ice streams? Earth Science Reviews, 103(1-2), 45-49.

\section{Effect of buried valleys on groundwater flow: a case study in the vicinity of Ventspils, NW Latvia}

Aija Dēliṇa, Kristīne Dūdiṇa and Konrāds Popovs

University of Latvia, Latvia

Buried subglacial valleys are common feature of the Quaternary sedimentary cover. These valleys have characteristic geometry - narrow, elongated outline in a plan view and deep cut in the pre-Quaternary sedimentary rock. However, valleys could be filled with various, mainly Pleistocene sediments - either till of different ages or sand and gravel or interbedding of both above mentioned. The filling material of the valleys influences groundwater flow in the aquifers cut by the valleys. It is supposed that glacial till filled valleys serves as a barrier to groundwater flow and as a recharge conduit when filled with sand and gravel deposits.

Studies of effect of the buried valleys on groundwater flow in a confined aquifer (Middle Devonian Arukila aquifer, $\mathrm{D}_{2}$ ar) were carried out applying numerical modelling. The vicinity of Ventspils, near wellfield Ogsils was chosen, as there were number of the buried valleys with different depth and filling, and sufficient amount of geological and 
hydrogeological data for the model development.

Numerical model was developed on MOSYS script base (Virbulis et al. 2012) using finite element triangular mesh. Modeling approach involved building of several structures where different hydraulic conductivity values were applied for the valleys filling afterwards. The main structure for calculations included buried valleys, and the structure without valleys was created a reference one. Hydraulic conductivity values of sediments of the buried valleys were changed in the calculation stage, so that one solution represents valleys filled with highly permeable sediments $(\mathrm{k}=10-15 \mathrm{~m} /$ day $)$ and another one - valleys filled with low permeable sediments $(\mathrm{k}=0,0005-0,001 \mathrm{~m} /$ day $)$.

Modelled piezometric heads for different valley types varies rather significantly (Figs. 1, 2 and 3). Permeable valleys serve as continuation of cut aquifer and no disruptions in piezometric head distribution in the particular aquifer are observed. They serve as recharge areas for the aquifer (Figs. 1A and 2). Low permeable valleys do not facilitate aquifer recharge and disturb groundwater flow within the aquifer which is shown by the disturbances in piezometric head distribution near valleys (Figs. 1B and 3).
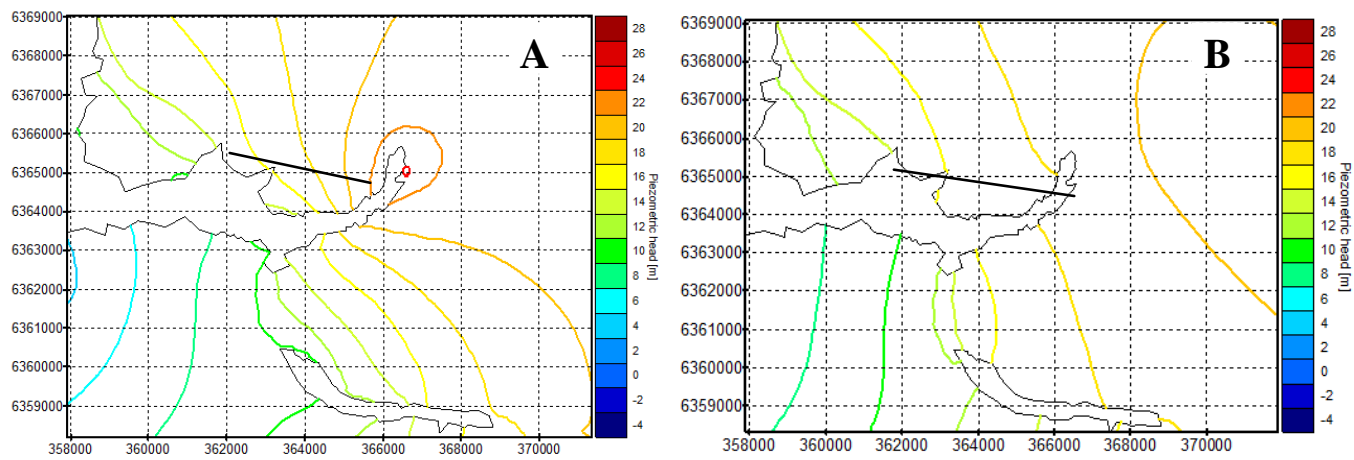

Fig. 1. Modelled piezometric heads in the Arukila confined aquifer: A. Buried valleys filled with sand and gravel sediments, B. Buried valleys filled with till sediments. Thin black lines - aquifer distribution border, thick black line shows location of cross-sections of Figs. 2 and 3.

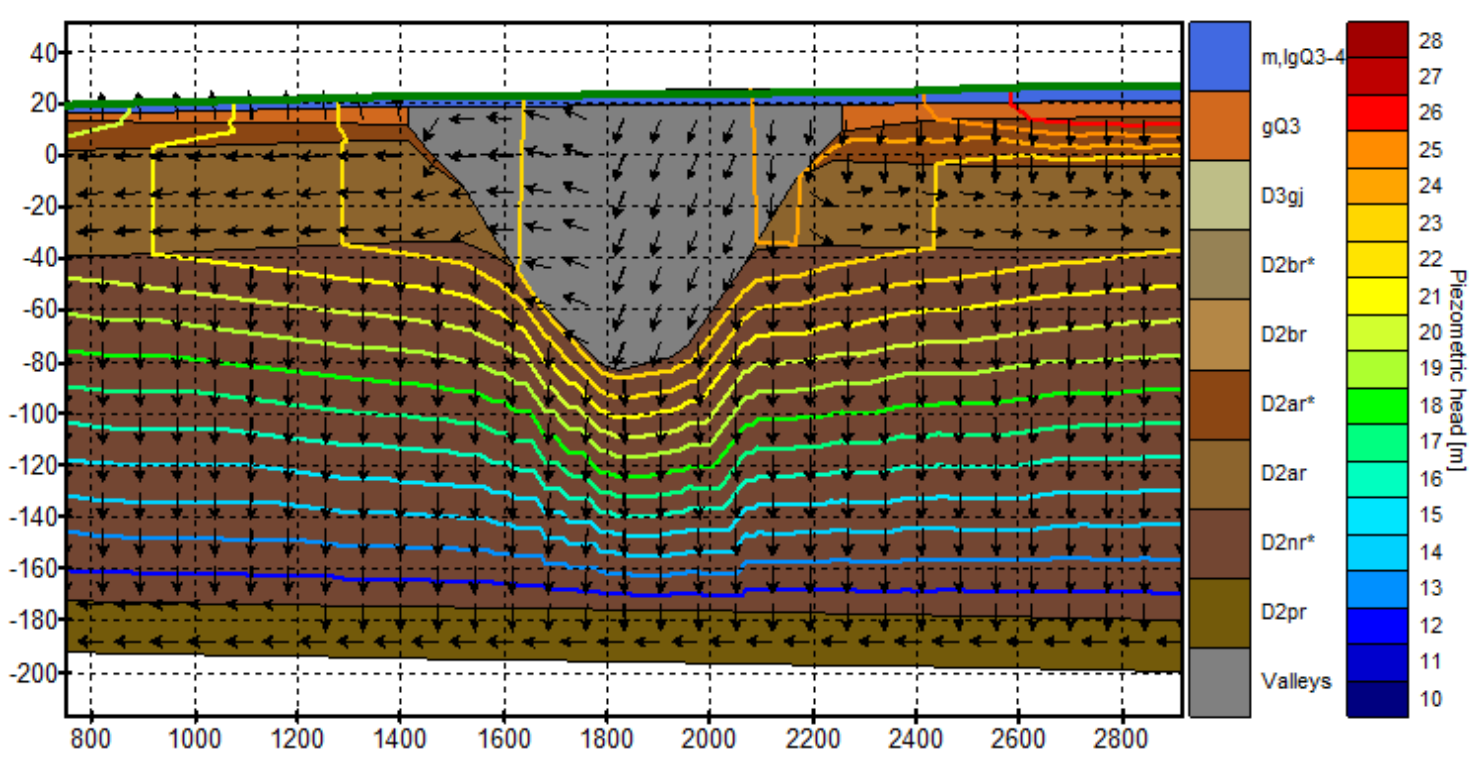

Fig. 2. Modelled piezometric head distribution near buried valley filled with sand and gravel sediments.

The results approve initial suggestions that buried valleys filled with till sediments and cutting into confined aquifer serves as a barrier in groundwater flow, causing sharp drop of piezometric head and downward flow within whole valley area (Fig. 3). And on contrary, 
valleys filled with sand and gravel sediments have minimal influence on piezometric head distribution (Fig, 2), but facilitate recharge from shallower aquifers and groundwater exchange within the valley. The study shows that piezometric head distribution disturbances within the structure with buried valleys are spatially limited next to the valleys comparing to the structure without valleys.

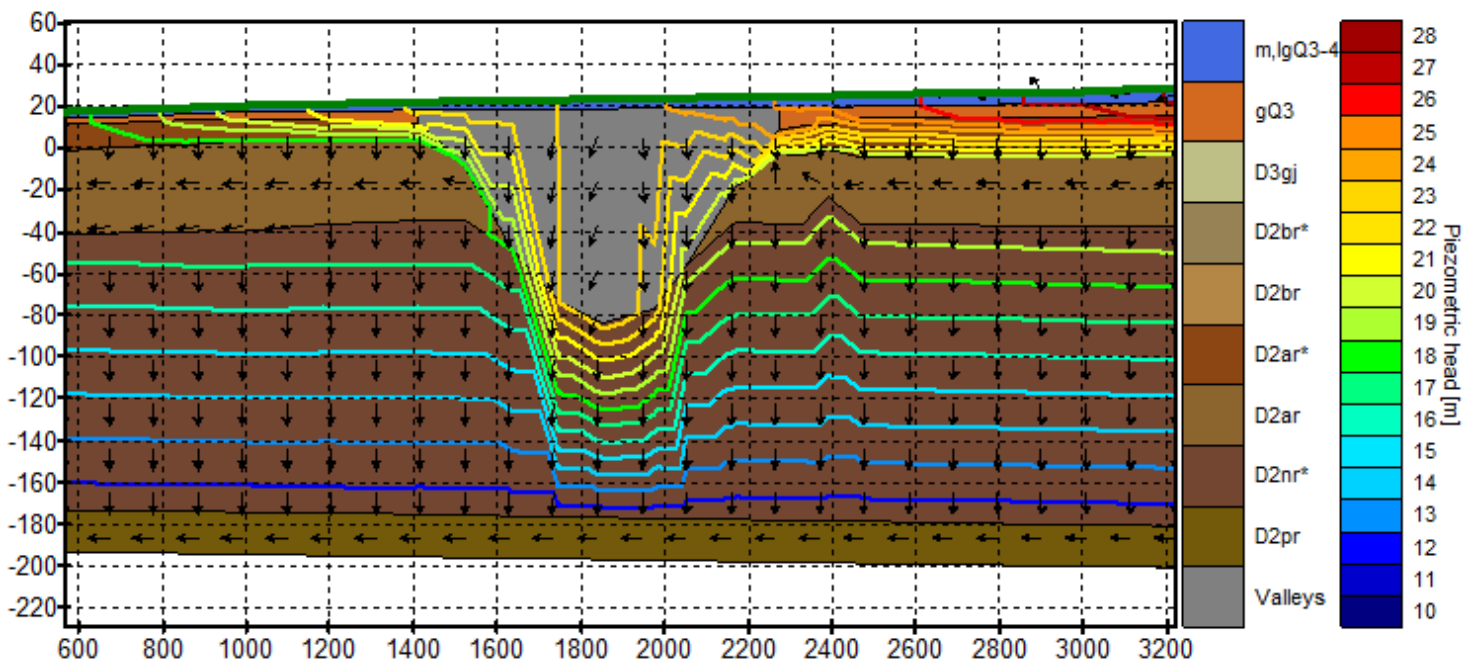

Fig. 3. Modelled piezometric head distribution near buried valley filled with till sediments.

This study is supported by the European Regional Development Fund project Nr.2013/0054/2DP/2.1.1.1.0/13/APIA/VIAA/007 in Latvia.

\title{
Reference
}

Virbulis, J., Timuhins, A., Klints, I., Seņņikovs, J., Bethers, U., Popovs, K. 2012. Script based MOSYS system for the generation of a three dimensional geological structure and the calculation of groundwater flow: case study of the Baltic Artesian Basin. In: Highlights of groundwater research in the Baltic Artesian Basin. University of Latvia, Riga, pp. 53-74.

\section{New data on the palaeoenvironment of South-Eastern Baltic region: results of the scientific project RFBR 1205-33013}

\author{
Olga Druzhinina
}

\section{Kant Baltic Federal University, Kaliningrad, Russia}

In 2013 the major part of the field and laboratory studies in the frame of the scientific project RFBR 12-05-33013 "Evolution of the environment of the South-Eastern Baltic Region and the stages of early settling of the territory on the Pleistocene-Holocene border" has finished. The most of obtained data are in processing now, although it is already possible to discuss some preliminary results. One of the most interesting are related with palaeolimnological studies of the lake Kamyshovoe (Vishtynetskaya hill, Kaliningrad region RF).

In 2012-2013 sediment cores of $10 \mathrm{~m}$ and $75 \mathrm{~m}$, presented both by Late-glacial and Holocene deposits (high organic brown gyttja, gray-brown clay gyttja and dark gray clayish silt) were obtained. Approximately 200 samples are processing. Study of samples included radiometric dating (AMS and ${ }^{14} \mathrm{C}$ ), palynological, geochemical, diatom analysis, analysis of isotopes $\left(\delta^{18} \mathrm{O}, \delta^{13} \mathrm{C}\right)$ and magnetic susceptibility, and other kinds of work. Preliminary results are following. 
Analysis of the magnetic susceptibility of sediments revealed significant changes of the parameter from $5 \times 10^{-9} \mathrm{~m}^{3} \mathrm{~kg}^{-1}$ to $194 \times 10^{-9} \mathrm{~m}^{3} \mathrm{~kg}^{-1}$, associated with the different cycles of sedimentation and indirectly confirming the presence of the Late- glacial stage in this process. Analysis was carried out in the Nature Research Centre at the Institute of Geology and Geography, Vilnius.

Radiometric dating $\left({ }^{14} \mathrm{C}\right)$ of samples - the earliest dating (Lu-6980, $\left.8740 \pm 160\right)$ was obtained from a depth of 8.3-8.4 m from the surface of the water. Samples were analysed from the higher, the Holocene part of the column. Analysis was performed in the Laboratory of Geochronology at the St. Petersburg State University (Prof. K. A. Arslanov).

Analysis of total organic carbon (TOC) revealed the dynamics of this indicator of biological efficiency over time. This analysis conducted in the Herzen State Pedagogical University (Prof. D.A. Subetto, Y. Kublitsky).

Palynological analysis allowed to get essential results, showing the relation of the sediments from the bottom of the column with the end of Pleistocene. Analysis conducted by Dr. M. Stanchikaite in the Nature Research Centre at the Institute of Geology and Geography, Vilnius. Diatom analysis highlighted various environmental groups of diatoms with the characteristic of the habitat groups. Analysis conducted by Dr. G. Vaikutiene (Vilnius University).

Results of AMS dating, performed at the Poznan Radiocarbon Laboratory, revealed older dates of the samples than it was expected due to previous biostratigraphical analysis. This needs further discussion and interpretation.

The results confirmed the assumption of the Late-glacial genesis of the reservoir. The final stage of research will allow to describe the dynamics of various natural processes in this part of the South-Eastern Baltics, including climate change, evolution of the vegetation, dynamics of the hydrological and geomorphologic processes etc., gradually over the past approx. $12 \mathrm{ka}$.

This scientific project was financed by the Russian Foundation for Basic Research (project 12-05-33013). The author expresses sincere gratitude to all Lithuanian and Russian colleagues, participating in the research.

\title{
Post-glacial environmental changes and the earliest human inhabitance of the Lake Dukštelis area, Eastern Lithuania
}

\author{
Laura Gedminiené $\dot{a}^{\mathrm{a}}$ Gabrielè Rimkuté ${ }^{\mathrm{b}}$ and Miglè Stančikaitè \\ ${ }^{a}$ Vilnius University, Lithuania \\ ${ }^{\mathrm{b}}$ Nature Research Centre, Institute of Geology and Geography, Lithuania
}

An interdisciplinary approach involving the integration of archaeological, geological and environmental survey techniques has been applied to investigate environmental and human history in a single region of the Eastern Lithuania. In recent years this approach has

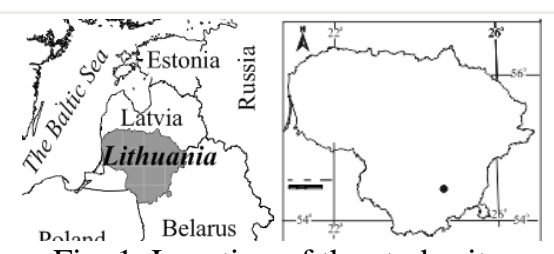

Fig. 1. Location of the study site. enabled the collection of abundant new data relating to environmental changes both on a local and a regional scale. Two projects are currently in progress: "Postglacial environmental changes in Eastern Lithuania and their relationship to globally determined fluctuations in climate" (geological and environmental study) and "The 
Earliest Human Inhabitance of the North-Western part of the River Neris Basin, Lithuania" (archaeological study).

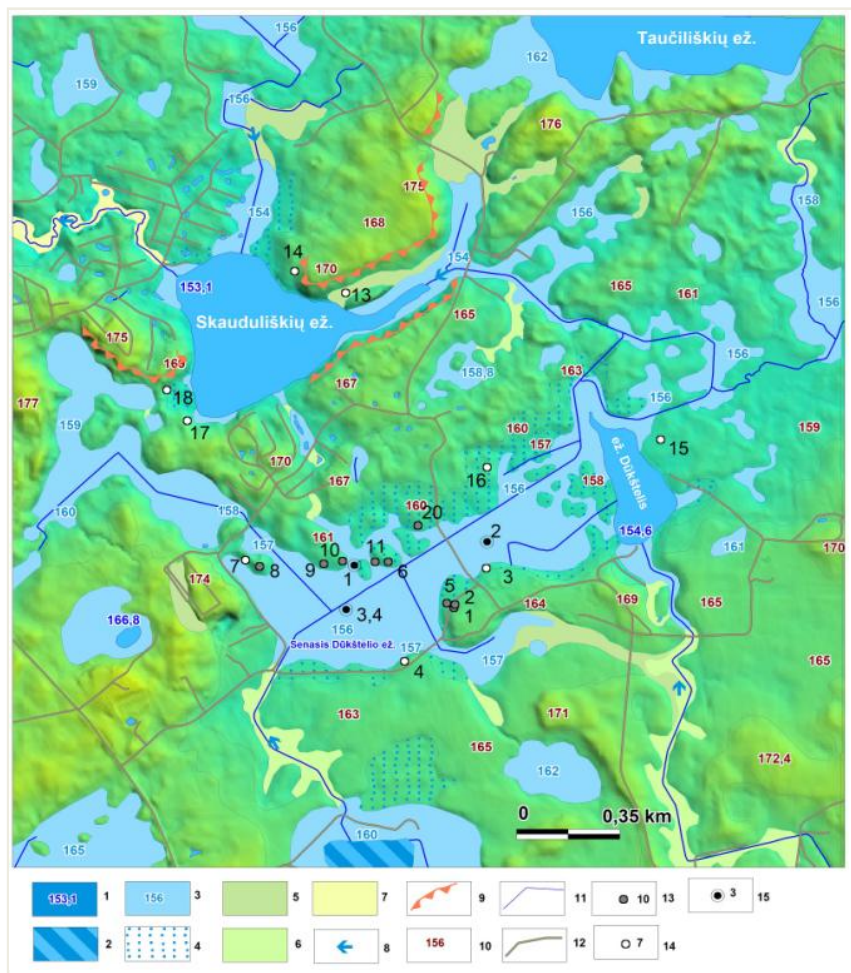

Fig. 2. Postglacial lake Dūkštelis and Skauduliškių view (The Digital Reconstruction model, LIDAR). 1 - current lakes; 2 - lake, reconstructed from 1952 stereoscopic aerial photo; 3 - lateglacial lakes; 4 - postglacial lake terrace; 5 and 6 - postglacial rivers; 7 - current river terrace; 8 - river flow; 9 - steep shores; 10- last glacial surface level; 11 meliorated rivers; 12 - roads; $13,14,15$ - investigation sites (Guobvtè and Rimkutė 2013).

The River Neris is the second largest river in Lithuania, running from east to west, and the region of focus lies northwards of the river valley, around the remnants of a large lake, known as Dūkštelis (Fig. 1). Since the beginning of the Holocene it has decreased in size by around $85 \%$. Southwestwards from the extant lake Dūkštelis, a few sites containing evidence of human occupation dated back to the Early Mesolithic and Neolithic were found. In order to build a sound interpretation of human activity in the region it is also important to establish whether environmental and geomorphological conditions were favorable for human habitation during the mention time intervals. In the surrounding of Skauduliškès and Dūkštelis Lake the stereoscopic analysis of aerial photography was done in 2012 (Fig. 2). As a result, high correlation between geomorphological prehistoric lake band reconstruction and newly discovered archaeological sites has been revealed (Guobytė and Rimkutė 2013).

In conjunction with this work, further analysis of the lake bottom sediments was carried out. Two cores, about 13 meters each, were taken from the middle part of the lake. Sedimentological survey i.e. LOI (methodic by Bengtsson and Enell 1986) and grain-size measurements (using ANALYSETTE 22 MicroTec plus) were done. Results have shown lithological composition of the sediment core. It consists of thick gyttja covering silty clay, overlain with organic matter on the top. Lithological fluctuations indicate three major abrupt alterations of the sedimentary environment (Fig. 3).

A reconstruction of the palaeoenvironmental from lake sediments was made. Samples at two-centimeter intervals for pollen analysis were taken. In the five meters of the bottom sediments, 5 LPAZ were distinguished (Fig. 3). Results of the palynological analysis show a strong relationship with lithological and sedimentological data. The present study exhibits changes in nutrient status and groundwater flow during the last Glacial-Interglacial transition. The moss layer at the base of the depression marks the beginning of water table rise as a consequence of the warming. Not rich in organic and calcareous gyttja deposits, very laminated layers and mixed grain size in LPAZ 1-3 shows unstable climatic conditions in the region. Pollen diagram shows that Betula predominating tundra with thin soil cover existed at that time. LPAZ 4-5 shows that rich soils and warmer climatic conditions tolerating vegetation, Corylus, Ulmus, Alnus, Quercus started to dominate at the region (Fig. 3). 


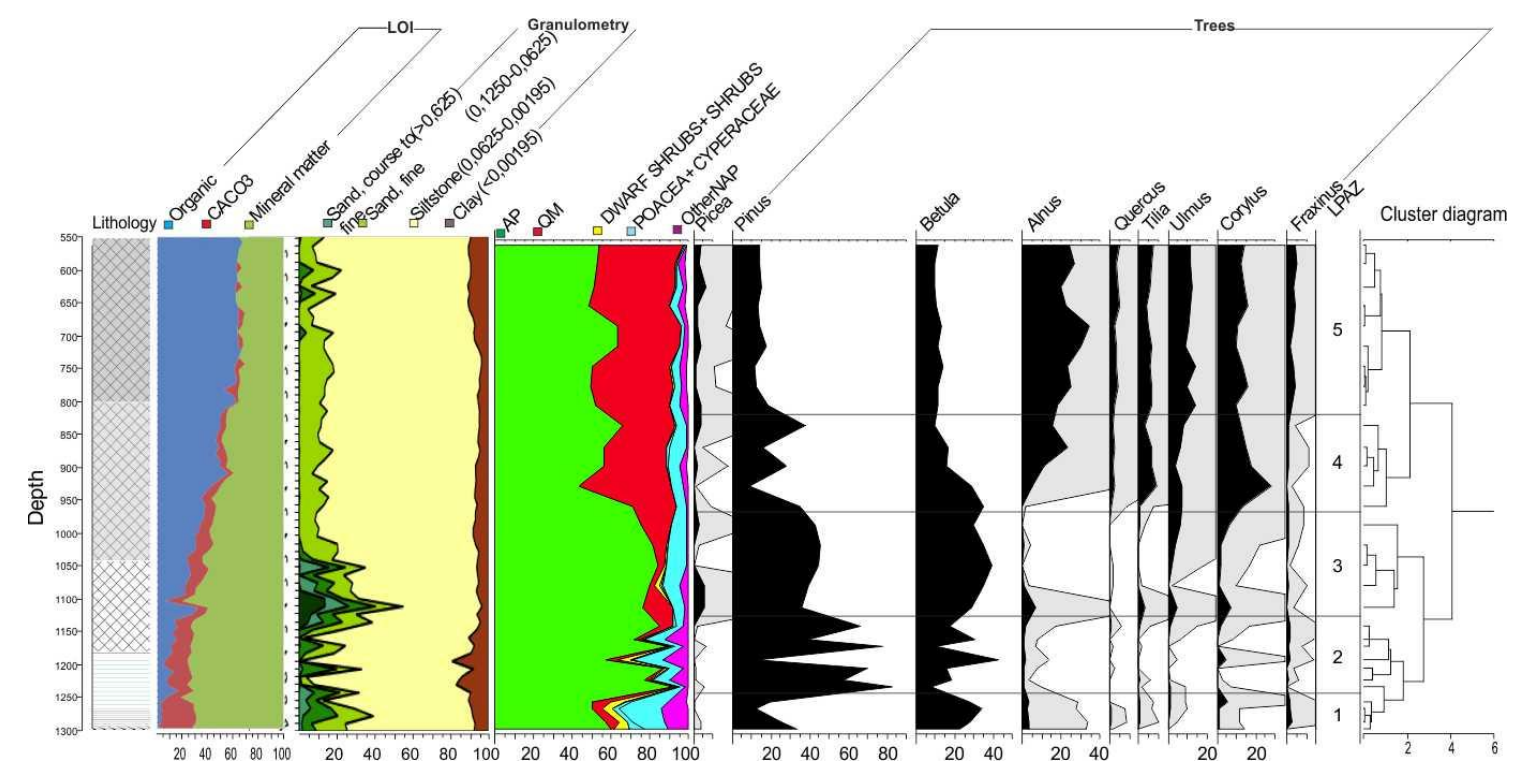

Fig. 3. Summarizing lithology, LOI, granulometry and a percentage pollen diagram of selected taxa from Dūkšteliai lake sediments. LOI - loss in ignition; QM -Quercetum mixtum, AP - arboreal pollen, NAP - non arboreal pollen. Analysed by L. Gedminienè and M. Stančikaitė (2013), granulometry by M. Kazbaris (2013).

The results of the complex investigations suggest that the sedimentation in the lake started after the last glacial maximum. As climatic conditions became stable, and the soil of the region got richer, the favorable conditions occurred allowing human occupation around the shores of the lake. It is possible to distinguish at least two phases of inhabitance based on the flint types present, potentially representing the Early Mesolithic, Neolithic and/or Bronze Age. The evidence suggests that Mesolithic people had good access to raw materials in the South and could procure flint of very good quality as there are some semi-straight blades and an unipolar knapping technique can be recognized, while later Neolithic people were re-using flint left by their predecessors, or manufacturing tools from the few poor quality flint nodules found locally. Also few archaeological objects were discovered: a hearth and some burnt structure spots, which are not dated yet.

In addition, $\delta^{18} \mathrm{O}$ analysis of the silty clay and palaeoclimate delineation in all sediment sections using magnetic susceptibility (MS) data will also be performed. MS is used to provide a proxy for climate at the time the sediments were deposited. MS works as a proxy in many materials because changing climate alters the magnetic properties of sediments during pedogenesis. During soil formation (with corresponding increases in MS) production of some minerals - maghemite, hematite or possibly greigite is high during periods when the climate is relatively warm (assuming that moisture is available for pedogenesis) (Fine and Singer 1995). In Lithuania this method is very new and not many lake sediments were analysed with it, so it might give us a new approach to the environmental changes and human impact.

\section{References:}

Bengtsson, L., Enell, M. 1986. Chemical analysis. In: Begrlund, B.E. (ed.), Handbook of Holocene Palaeoecology and Palaeohydrology. John Wiley \& Sons, Chichester, pp. 423-454.

Fine, P., Singer, M.J., Verosub, K.L. 1995. Pedogenic and lithogenic contributions to the magnetic susceptibility record of the Chinese loess/ palaeosol sequence. Geophysical Journal International, 122 (1), 97-107.

Guobytė R., Rimkutė G. 2013. Aerofotonuotrauku stereoskopinès analizès panaudojimas archeologiniuose tyrimuose. Metodai Lietuvos archeologijoje. Mokslas ir technologijos praeičiai pažinti, Vilnius, pp. 606-617. 


\section{Development of the Plateliai area in Late Weichselian and Holocene, NW Lithuania}

Alma Grigiene and Asta Jusiene

\section{Lithuanian Geological Survey, Lithuania}

Surroundings of the Lake Plateliai situated in north-western part of Samogitian Highland have been formed by Saalian and Late Weichselian Glaciations that left steep sloped morainic hills as well as kames, kame terraces and plateau-like-hills. To reconstruct sediment accumulation in lakes and peat bogs and environmental changes in Post-glacial, three sediment cores for pollen analysis were taken in Velenija low moor, Endriuskaiciai high moor and Margupis River valley (Fig. 1).

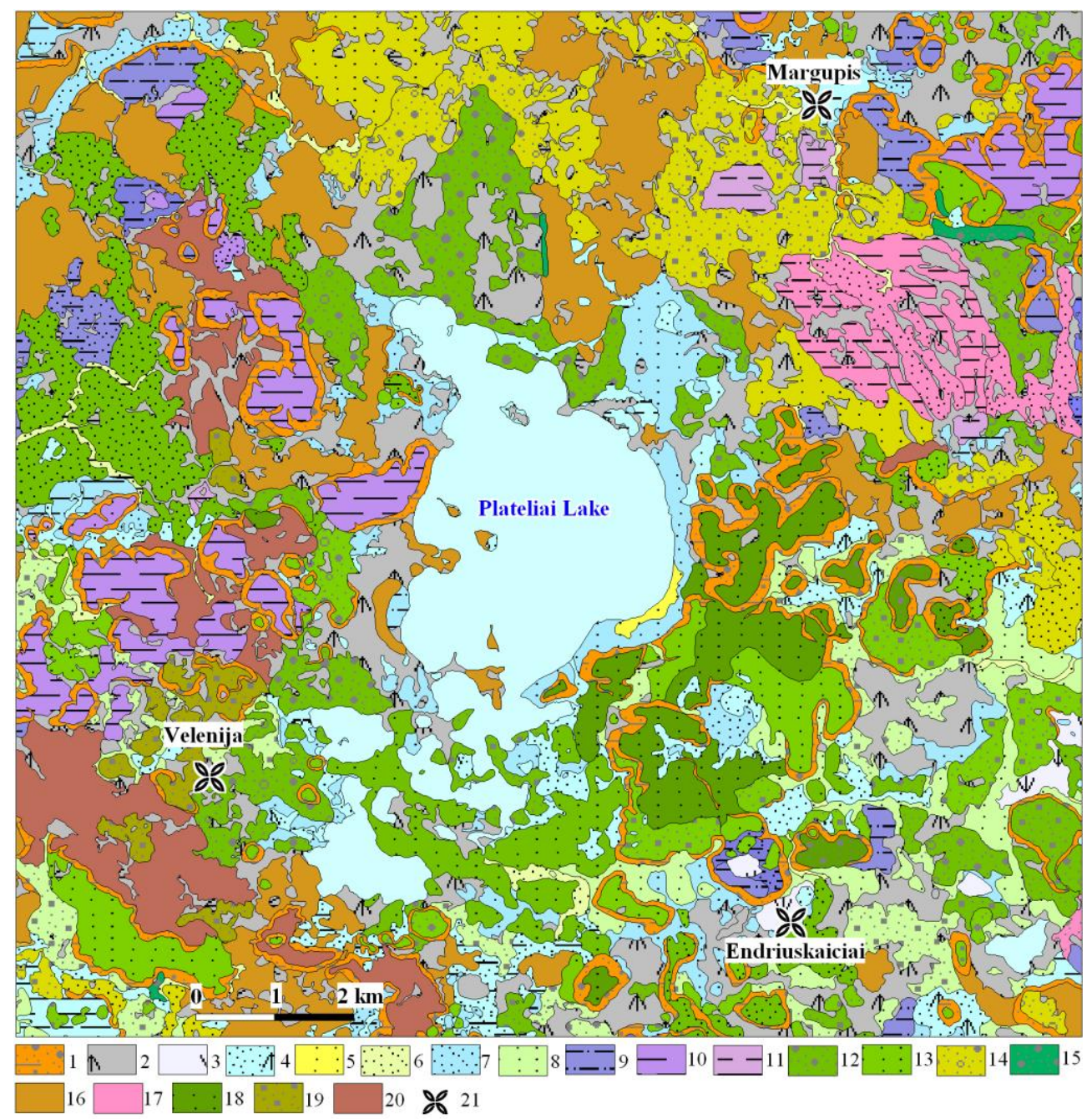

Fig. 1. Geomorphological map of the Lake Plateliai surroundings.

Legend: Holocene and Late-glacial: 1 - colluvium, 2 - low-moor peat; high-moor peat, 4 - lacustrine sand with peat, 5 - aeolian fine grained sand. 6 - alluvium; Upper Nemunas glacial, Upper Pleistocene: 7 - glaciolacustrine sand, 8 - glaciofluvial sand, 9 - glaciolacustrine clay of plateau-like hills, 11 - marginal glaciolacustrine deposits, 12 - glaciofluvial deposits of kame massifs, 13 - glaciofluvial deposits of kame terraces, 14 - marginal glaciofluvial deposits, 15 - deposits of eskers, 16 - marginal glacial loam, 17 - marginal deposits; Medininkai glacial, Middle Pleistocene: 18 - englacial glaciofluvial sand, 19 - marginal glaciofluvial sediments, 20 marginal glacial loam; 21 - sampling sites.

Results of palynological studies at the Margupis site show that lacustrine sediments (silt, sand and gyttja) started to accumulate in the Alleröd. Birch forest with admixture of pine grew 
in the territory. Reduction of the vegetation cover indicates a climatic cooling during the Younger Dryas. During the Preboreal climate was warm and dry and pine forest dominated.

Peat started to accumulate at about $8720{ }^{14} \mathrm{C}$. At $9325-9890{ }^{14} \mathrm{C}$ years BP (Vs-2213) (piece of wood from Velenija low moor was dated by radiocarbon method in the Institute of Geology and Geography at the Nature Research Centre) the water level dropped and formation of the peat started. The mixed birch-pine forest grew in the territory. Later broad-leaved forest and hazel spread.

According to pollen data the Endriuskaiciai high moor started to develop during the post-glacial climatic optimum. Then broad-leaved forest and hazel occupied the area. The amounts of broad-leaved trees decreased, spruce, pine and alder spread in Subboreal. During the Subatlantic the dominant local forest trees are spruce, pine, birch and alder. Accumulation of peat continues up to our days.

\section{Current issues of geological mapping in Schleswig-Holstein, Germany}

\section{Alf Grube}

Geological Survey Schleswig-Holstein, Germany

As part of the geological survey and the revision of the Geotop register of SchleswigHolstein different, from a scientific perspective interesting sites have been investigated. These include areas of karst in chalk areas, periglacial and aeolian forms and processes of tufa sedimentation.

Fossil caves with a volume of several thousand cubic metres were documented in the chalk of the structure Lägerdorf (SW Schleswig-Holstein). The filling of the cavities in the former chalk pit Heidestrasse consists of partially humus rich sand, gravel, sand, till, clay and silt, organic silt, as well as crystalline boulders of more than 0.5 meters in diameter. The results shows pre-Holocene karstification within the chalk, the subrosion was active subrecently.

The outflow of artesian groundwater locally leads to the formation of morphological crests and ridges of predominantly calcium deposits and peat. These forms were studied in different areas of Schleswig-Holstein. They can reach diameters of $150 \mathrm{~m}$ and a height of $3 \mathrm{~m}$. Aspects of their formation, as e.g. changing access of artesian confined groundwater, the influence of glacial tectonics and permafrost, are discussed.

During the rehabilitation of a refinery site in Wedel/Holstein peculiar periglacial structures were observed. These comprise small scaled gullies, which show a polygonal pattern. They are found on a surface of a cohesive, calcareous Saalian till and are filled with calcareous, silty sands, possibly mixed till material with some aeolian components. The genesis of the structures, including a possible connection with a glacitectonic fracture network is discussed.

A site near Großenaspe shows a clear dependence of the formation of inland dunes from the underlying glacial subsoil itself, outside the neighboring meltwater channel. At the site limnic-telmatic sediments of suspected Holsteinian and Eemian age were found in superposition. 


\section{Late Quaternary ice sheet dynamics in northeastern Germany - new insights in the formation of the Frankfurt ice marginal position based on the analysis of a high resolution LiDAR digital elevation model}

Jacob Hardt and Margot Böse

Freie Universität Berlin, Germany

The timing and course of the Frankfurt ice marginal position (IMP) are contentiously discussed in literature. In Germany this formation is seen as a standstill phase of the downwasting ice masses of the Brandenburg $\left(\mathrm{W}_{1 \mathrm{~B}}\right)$ phase. This explains the relatively weakness of the forms and that there is no specific till that can be assigned to the Frankfurt $\left(\mathrm{W}_{1 \mathrm{~F}}\right)$ phase (Cepek 1965; Ehlers et al. 2011; Böse et al. 2012).

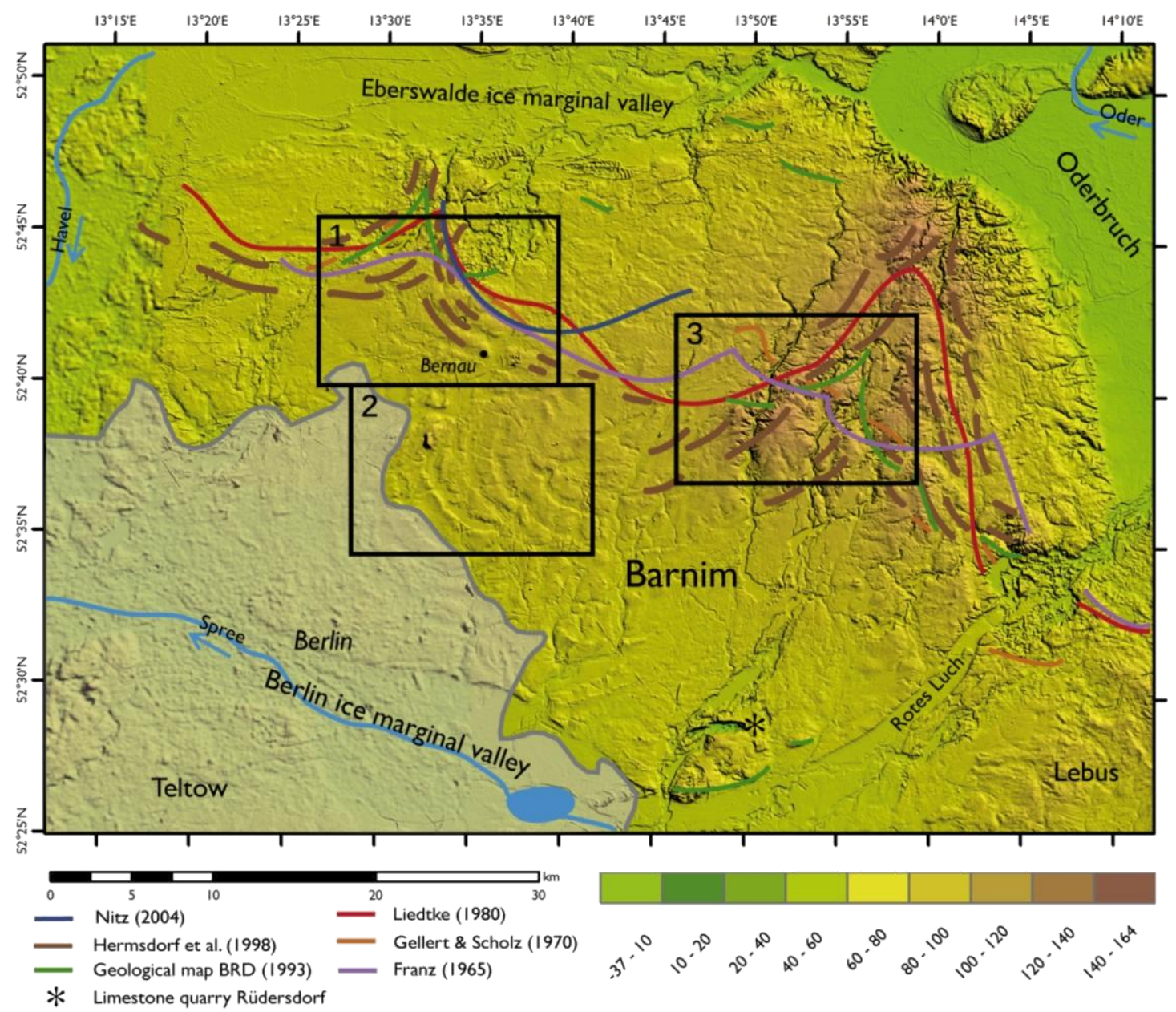

Fig. 1. The Barnim till plain (LiDAR DEM). Boxes 1-3 indicate the three subsets that were selected for detailed analysis. IMPs associated with $\mathrm{W}_{1 \mathrm{~F}}$ as stated by different authors.

Our study area, the Barnim till plain to the north of Berlin, is crossed by the Frankfurt IMP. Although the Barnim is an intensely studied glacial landscape, the course of the IMP is seen different by different authors (Fig. 1). So it appeared promising to us to reassess the geomorphology of the Barnim till plain with help of a high resolution (1m) LiDAR digital elevation model (DEM). For this purpose we created an integrated GIS database that contains geological and geomorphological information about the study area from detailed literature study. The DEM was analysed qualitatively and compared to the information collected in the 
GIS. Due to the size of the Barnim till plain $\left(\sim 1900 \mathrm{~km}^{2}\right)$ we selected three representative subsets for detailed analyses, each covering an area of $\sim 150 \mathrm{~km}^{2}$.

The most remarkable discovery was made in the middle Barnim area. Here we identified a set of consecutive arcuate ridges. Their widths (NE-SW) are around 1000-1500 m, and their lengths are around 10-15 km; they rise some $10 \mathrm{~m}$ above their surroundings. According to geological maps and our own fieldwork, they are covered by till. The inner sides of the ridges are northeast-oriented and rather steep, and the outer sides face southwest with a dip at a flatter angle. The ridges are incised radially, indicating erosion by meltwater runoff. A sandy or peaty substrate was deposited in the depressions between the ridges. The lobe-like shape of the ridges and the distribution of the sediments suggest a glacial origin.

Fine gravel analyses from other studies imply that the till at the surface of the ridges can probably be associated with a Weichselian ( $\mathrm{W}_{1 \mathrm{~B}}$ ) ice advance (Gärtner 1993; Bussemer 2002).

According to the interpretation of the gathered data we propose that the ridges were formed in the sense of recessional moraines that developed in front of an oscillating glacier lobe. Similar forms were recently found around the ice margin of piedmont glaciers, e.g. the Malaspina glacier in southwest Alaska.

Regarding the existing stratigraphical and geochronological data their formation may either have happened prior to the $\mathrm{W}_{1 \mathrm{~B}}$ phase during the inland ice advance or between the $\mathrm{W}_{1 \mathrm{~B}}$ and $\mathrm{W} 2$ phase.

Recent studies have shed a new light on the timing of ice marginal landforms of the $\mathrm{W}_{1 \mathrm{~B}}$ and W2 phase (Lüthgens and Böse 2011; Lüthgens et al. 2011) in northeast Germany and further investigations are necessary to find out, how the formation of these landforms can be connected with the preceding and succeeding IMPs. However, other genetic possibilities cannot be excluded and, as stated before, further fieldwork and geochronological data are necessary to obtain a complete picture of the palaeoglaciological processes in the northeastern German lowland.

It could be shown that high resolution LiDAR-DEM data significantly increases the recognition of landscape elements in the study area.

\section{References}

Böse, M., Lüthgens, C., Lee, J. R., Rose, J. 2012. Quaternary glaciations of northern Europe. Quaternary Science Reviews, 44, 1-25.

Bussemer, S. 2002. Quartäre Entwicklung und Gliederung der Binnenentwässerungsgebiete auf der Barnimhochfläche (NE-Brandenburg). Greifswalder Geographische Arbeiten, 26, 4.

Cepek, A. G. 1965. Die Stratigraphie der pleistozänen Ablagerungen im Norddeutschen Tiefland. In Gellert, J. F. (ed.): Die Weichsel-Eiszeit im Gebiet der Deutschen Demokratischen Republik. Akademie-Verlag, Berlin, S. 45-65.

Ehlers, J., Grube, A., Stephan, H.-J. \& Wansa, S. 2011. Chapter 13: Pleistocene Glaciations of North Germany New Results. Ehlers, J., Gibbard, P.L., Hughes, P.D. (eds.), Quaternary glaciations - extent and chronology: a closer look. Developments in Quaternary Science, 15. Elsevier, Amsterdam, pp. 149-162 pp.

Gärtner, P. 1993. Beiträge zur Landschaftsgeschichte des westlichen Barnim. Berliner Geographische Arbeiten, 77, S. 1-109.

Lüthgens, C., Böse, M. 2011. Chronology of Weichselian main ice marginal positions in north-eastern Germany. Quaternary Science Journal , 60(2-3), 236-247.

Lüthgens, C., Böse, M., Preusser, F. 2011. Age of the Pomeranian ice-marginal position in northeastern Germany determined by Optically Stimulated Luminescence (OSL) dating of glaciofluvial sediments. Boreas, 40, 598-615. 


\title{
ABCGheritage project - geological cooperation in northern Fennoscandia
}

\author{
Peter Johansson $^{\mathrm{a}}$, Yury Voytekhovsky ${ }^{\mathrm{b}}$; Laura S. Lauri ${ }^{\mathrm{a}}$ and Jouni Pihlaja ${ }^{\mathrm{a}}$ \\ ${ }^{\mathrm{a}}$ Geological Survey of Finland, Finland \\ ${ }^{\mathrm{b}}$ Geological Institute of the Kola Science Centre of the Russian Academy of Sciences, Russia
}

In the wilderness areas of the Barents Region all kinds of nature tourism, hiking and experience industry are steadily gaining in popularity. Due to this, a cooperation project ABCGheritage (Arctic Biological, Cultural and Geological Heritage) was planned to boost the tourism services, enhance the scientific background of eco-tourism and harmonize the activities with the environment. In the spring 2012 the project started with partial funding of partners are the Northern Finland Office of the Geological Survey of Finland and the Geological Institute of the Kola Science Centre of the Russian Academy of Sciences.

Different actions were planned to be implemented in the geological part of the project (Johansson et al. 2011; Johansson and Voytekhovsky 2013; Johansson, 2014). One of the main tasks is to prepare the "Barents Tour for Geotourists" trail. It includes the best geological demonstration sites along a circle route from northern Finland to northeastern Norway, from there across the Kola Peninsula to the White Sea coast and then back to northeastern Finland. The demonstration sites include Precambrian bedrock exposures and minerals in the Kola Peninsula, including locations with e.g. amethyst, tourmaline, eudialyte and astrophyllite. The tour also comprises Europe's only active amethyst mine on top of the Lampivaara fell in the Finnish Lapland, closed gold mines and historical mine shafts at Laanila, northern Lapland and Quaternary landforms, e.g. potholes, eskers, meltwater channels, moraines and raised beaches. Information on the tour will be published in English, Finnish, Russian and Norwegian as a guide book, web pages and an exhibition.

Another primary task of the project is to prepare a geological outdoor map and a guide book of the Khibiny Tundra in the Kola Peninsula. In Finland, GTK has published already 11 such maps from the most important national parks and recreation areas. The experiences gained during their production will be used in this project. Educational material on geological heritage and a supplemental package for teachers will also be produced. Materials for exhibitions, excursions, seminars and meetings focusing on geology and geotourism will be prepared. Field training courses will be arranged for people working in the tourism sector or in nature guiding and teaching. Nature trails and information panels based on the studies performed on the geological demonstration sites will also be created. The implementation time of the project is to the end of 2014.

\section{References}

Johansson, P. 2014. ABCG heritage project and Barents Tour for Geotourists. In: $31^{\text {st }}$ Nordic Geological Winter Meeting. Lund, Sweden, January 8-10, 2014. Abstracts, p. 168.

Johansson, P., Itkonen, P., Pihlaja, J., Voytekhovsky, Y. 2011. Development of geotourism in North Finland and Kola Peninsula, Russia. In: Geoconservation for the future: regular meeting, working group of ProGEO Northern Europe, Oslo, Norway, 21-23 September 2011. Oslo, Naturhistorisk museum, pp. 20-21.

Johansson, P., Voytekhovsky, Y. 2013 Geotourism activities in north Finland and northwestern Russia. In: the Spirit of the Rovaniemi Process. International Arctic Conference, December 2-4, 2013 Rovaniemi, Finland. Conference keynote speakers, invited experts for scientific sessions and abstracts for scientific sessions, p. 34. 


\title{
Application of the pulsed OSL in feldspar contaminated aeolian sediments: a case study of Eastern Latvia and Southern Estonia
}

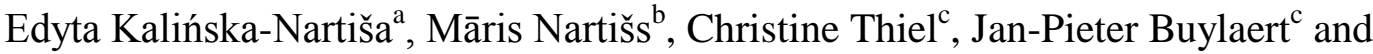 \\ Andrew Sean Murray ${ }^{c}$ \\ ${ }^{\mathrm{a}}$ University of Tartu, Estonia \\ ${ }^{\mathrm{b}}$ University of Latvia, Latvia \\ c Aarhus University, Denmark
}

Luminescence dating techniques determine the time passed since the last exposure of mineral grains to sunlight; thus the time of deposition could be constrained (Aitken 1998). In luminescence dating, the two most commonly used minerals as quartz and feldspar are exposed to different dose rates (Ankjærgaard et al. 2010). Quartz is usually considered to be a reliable dosimeter than feldspar due to (1) not showing anomalous fading and (2) more rapid emptying the signal during the daylight exposure (Thomsen et al. 2008). Thus, quartz and feldspars are usually separated by physical and chemical treatment prior to measurement (Wintle 1997).

To evaluate the palaeoenvironmental development of the aeolian sediments in Eastern Latvia and Southern Estonia a total of nine samples were taken from six aeolian or aeolian substratum sediment representing localities Smilškalni, Majaks, Silezers, Niedrupite, Melderitis (Latvia) and Mustjõgi (Estonia). Samples were collected from freshly cleaned sections in opaque PVC tubes in order to avoid a light exposure. Wet sieved 180-250 $\mu \mathrm{m}$ sample fraction was treated with $\mathrm{HCl}, \mathrm{H}_{2} \mathrm{O}_{2}$ and $\mathrm{HF}$. Finally, after the heavy liquid separation, the quartz-rich extract was etched with $40 \% \mathrm{HF}$ for one hour to remove any remaining feldspar. To evaluate the purity of the extracted quartz, three aliquots of each sample were tested by stimulation with infra-red light following suggestion of Duller (2003). All quartz extracts exhibit feldspar contamination, thus the second etching was applied. After this aggressive treatment, no pure quartz signal could be obtained, thus implying the quartz contamination. A post-IR pulsed blue OSL (Denby et al.; 2006; Thomsen et al. 2008) single aliquot regenerative dose protocol (Murray and Wintle 2000) was applied, using an automated Ris $\varnothing$ TL/OSL reader (Thomsen et al. 2006). In pulsed OSL the stimulation light is delivered in discrete pulses and the emitted luminescence measured between those pulses (Thomsen et al. 2008). In our protocol pulsed blue stimulation at $125^{\circ} \mathrm{C}(100 \mathrm{~s})$ was applied, with on and off time of both $50 \mu \mathrm{s}$.

Aeolian sediments date with the most dates falling into the interval of 13.7-11.9 ka. These ages coincidence roughly with the GI 1c (Björck et al. 1998; Walker et al. 1999) to the onset of the Younger Dryas (Rasmussen et al. 2006; van Hoesel et al. 2014) and the GS-1 event in the Greenland Ice Core stratigraphy (Steffensen et al. 2008). Simultaneously, three sites obtained OSL age yielding between $165-16$ ka seem to be seriously overestimated due to potential incomplete or partial bleaching. Clearly, the reliability or possible age overestimation of the three aforementioned sites needs to be resolved by testing feldspar as a dosimeter. The use of pulsed OSL allowed to obtain results on samples not passing feldspar contamination test.

The study was funded by the Postdoctoral Research Grant ERMOS (FP7 Marie Curie Cofund the "People" programme) "Age and climatic signature of coversand deposits distributed on glaciolacustrine basins along the Scandinavian Ice Sheet margin southeast of the Baltic Sea". 


\section{Reference}

Aitken, M.J. 1998. An introduction to optical dating : the dating of Quaternary sediments by the use of photonstimulated luminescence. Oxford University Press, Oxford/New York/Tokyo, 267 pp.

Ankjærgaard, C., Jain, M., Thomsen, K.J., Murray, A.S. 2010. Optimising the separation of quartz and feldspar optically stimulated luminescence using pulsed excitation. Radiation Measurements, 45, 778-785.

Björck, S., Walker, M.J.C., Cwynar, L.C., Johnsen, S., Knudsen, K.-L., Lowe, J.J., Wohlfarth, B. 1998. An event stratigraphy for the Last Termination in the North Atlantic region based on the Greenland ice-core record: a proposal by the INTIMATE group. Journal of Quaternary Science, 13, 283-292.

Denby, P.M., Bøtter-Jensen, L., Murray, A.S., Thomsen, K.J., Moska, P. 2006. Application of pulsed OSL to the separation of the luminescence components from a mixed quartz/feldspar sample. Radiation Measurements, 41, 774-779.

Duller, G.A.T. 2003. Distinguishing quartz and feldspar in single grain luminescence measurements. Radiation Measurements, 37, 161-165.

Murray, A.S., Wintle, A.G. 2000. Luminescence dating of quartz using an improved single-aliquot regenerativedose protocol. Radiation Measurements, 32, 57-73.

Rasmussen, S.O., Andersen, K.K., Svensson, a. M., Steffensen, J.P., Vinther, B.M., Clausen, H.B., SiggaardAndersen, M.-L., Johnsen, S.J., Larsen, L.B., Dahl-Jensen, D., Bigler, M., Röthlisberger, R., Fischer, H., Goto-Azuma, K., Hansson, M.E., Ruth, U. 2006. A new Greenland ice core chronology for the last glacial termination. Journal of Geophysical Research: Atmospheres, 111, 1-16.

Steffensen, J.P., Andersen, K.K., Bigler, M., Clausen, H.B., Dahl-Jensen, D., Fischer, H., Goto-Azuma, K., Hansson, M., Johnsen, S.J., Jouzel, J., Masson-Delmotte, V., Popp, T., Rasmussen, S.O., Röthlisberger, R., Ruth, U., Stauffer, B., Siggaard-Andersen, M.-L., Sveinbjörnsdóttir, A.E., Svensson, A., White, J.W.C. 2008. High-resolution Greenland ice core data show abrupt climate change happens in few years. Science (New York, N.Y.), 321, 680-684.

Thomsen, K.J., Bøtter-Jensen, L., Denby, P.M., Moska, P., Murray, A.S. 2006. Developments in luminescence measurement techniques. Radiation Measurements, 41, 768-773.

Thomsen, K.J., Jain, M., Murray, A.S., Denby, P.M., Roy, N., Bøtter-Jensen, L. 2008. Minimizing feldspar OSL contamination in quartz UV-OSL using pulsed blue stimulation. Radiation Measurements, 43, 752-757.

Van Hoesel, A., Hoek, W.Z., Pennock, G.M., Drury, M.R. 2014. The Younger Dryas impact hypothesis: a critical review. Quaternary Science Reviews, 83, 95-114.

Walker, M.J.C., Bjo, S., Lowe, J.J., Cwynar, L.C., Johnsen, S., Knudsen, K., Wohlfarth, B. 1999. Isotopic "events" in the GRIP ice core: a stratotype for the Late Pleistocene. Quaternary Science Reviews, 18, $1143-1150$.

Wintle, A.G. 1997. Luminescence dating: laboratory procedures and protocols. Radiation Measurements, 25, 769-817.

\section{Deglacial ice dynamics in Estonia as derived from glacial bedforms}

\section{Katrin Kalla and Tiit Hang}

University of Tartu, Estonia

Earlier research into deglacial ice dynamics in Estonia at the end of the LateWeichselian glaciation has based predominantly on geomorphological correlations of ice marginal landforms, mapping of indicative radial formations and on till fabric analysis (Raukas and Karukäpp 1979; Karukäpp, 1997, Kalm, 2012). In this work glacial bedforms in Estonia were revisited using LIDAR-acquired digital elevation data in order to evaluate different elevation datasets for mapping glacial bedforms and interpreting ice dynamics. Recently Kalm (2012) compiled the terrain analysis using SRTM (Shuttle Radar Topography Mission) elevation data (resolution $70 \mathrm{~m}$ ) to interpret main ice flow directions and marginal landforms in Estonia. We discuss much more detailed air-borne LIDAR data (possible to derive grid sizes $5 \mathrm{~m}, 10 \mathrm{~m}, 25 \mathrm{~m}, 50 \mathrm{~m}$ and $100 \mathrm{~m}$ ) which largely supports these earlier results by adding more details and questioning the earlier ice flow directions in some areas (Fig. 1). 


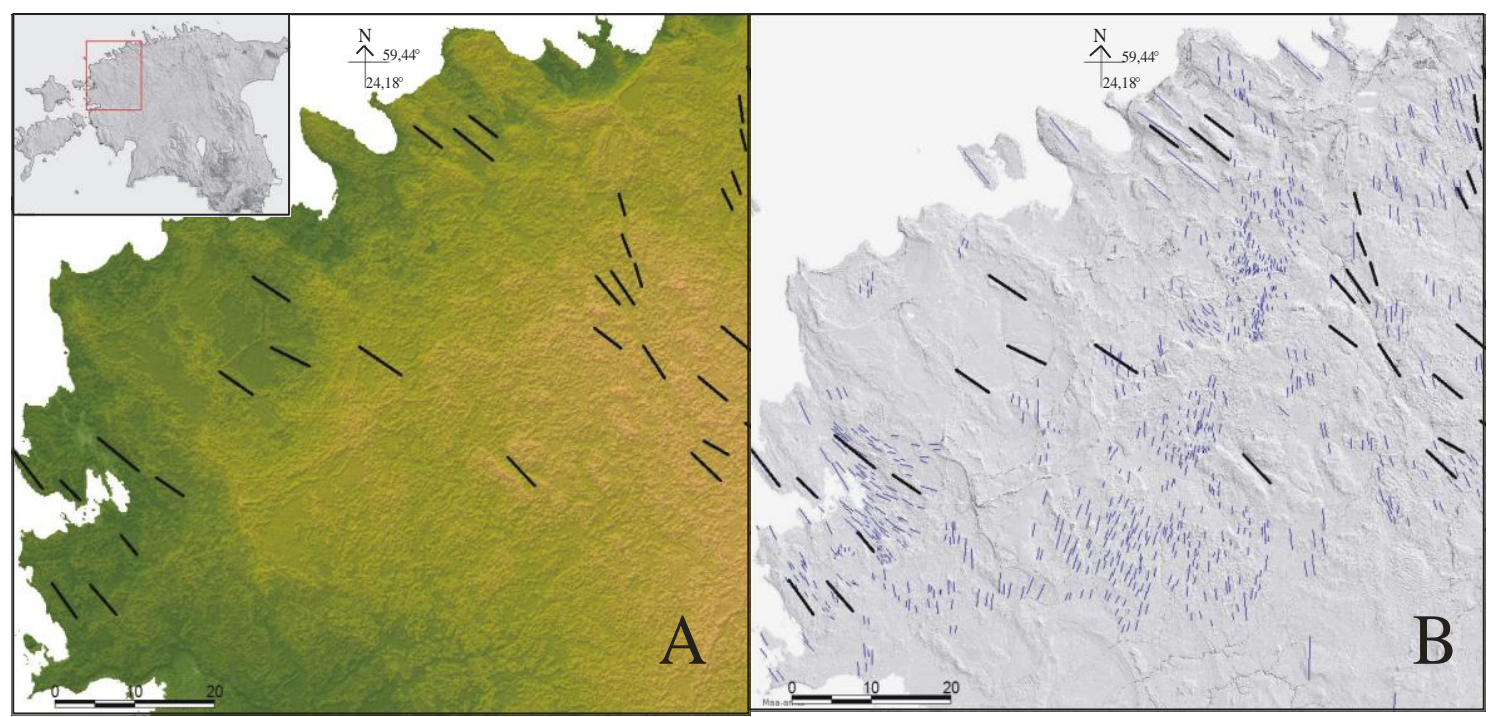

Fig. 1. An examples of DEM-s from NW Estonia based on SRTM elevation data (A) and LIDAR elevation data (B) with indication of glacial radial bedforms: black bold derived from SRTM and blue thin lines derived from LIDAR DEM. Marginal landforms not indicated. Rather clear boundary in appearance of bedforms in the lower part of the LIDAR DEM marks the transition to the distribution area of glaciolacustrine deposits which smooth the glacial topography.

Different generations of radial bedforms were recognized indicating individual ice flows. More details about marginal landforms allowed a new interpretation of ice margins in northern Estonia indicating also that many of marginal forms refer to recessional moraines at ice divides between different ice flows rather than substantial stagnation of ice margin (Fig. 2).

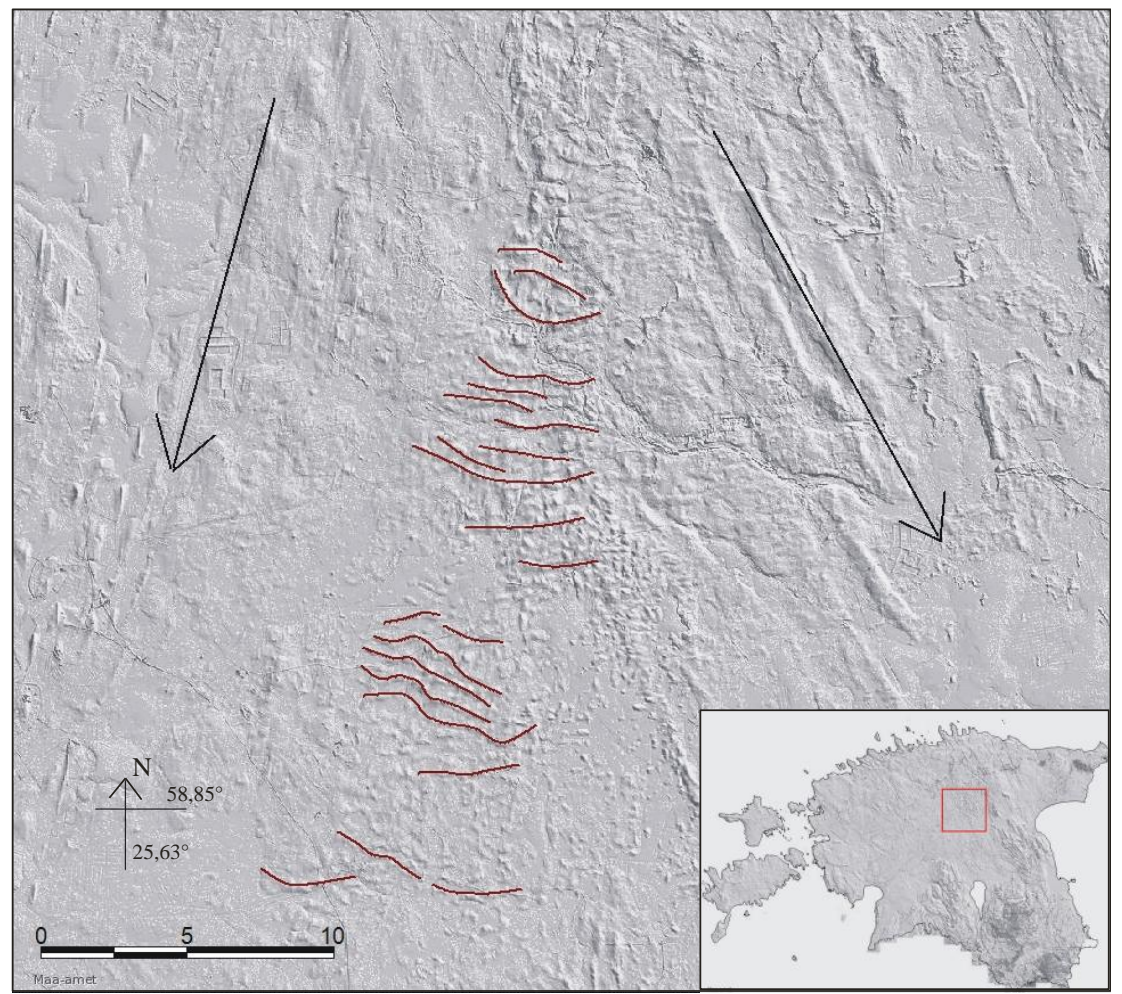

Fig. 2. A series of recessional moraines at ice divide indicated by clear radial bedforms and marked by arrows.

Glacial bedform mapping and interpretation was easier in areas with thin Quaternary sediment cover on the islands of West-Estonian archipelago and in northern Estonia. In 
western part of the country interpretations were complicated due to thick cover of glaciolacustrine deposits levelling the glacially designed topography (Fig. 1). The same concerns the central parts of SE Estonian uplands with thick Quaternary sediment cover and prevailing dead-ice hummocky topography.

LIDAR elevation data displays new possibilities for further morphological studies into glacial bedforms in order to interpret not only the ice-flow directions but also to interpret fast and slow flow areas of ice indicating thermal conditions at ice bed interface. For this it is inevitable to sort out a problem of delineating single glacial landforms on elevation model.

Further interpretations of individual ice flows and deglacial ice margins certainly needs better chronological control. Collaboration between University of Tartu and University of Stockholm has been set in order to date and complement the model of the deglaciation history in northern Estonia using OSL dates on glaciofluvial fines from the glaciofluvial deltas and outwash plains, first results of which will be discussed in separate presentation.

\title{
References
}

Kalm, V. 2012. Ice-flow pattern and extent of the last Scandinavian Ice Sheet southeast of the Baltic Sea. Quaternary Science Reviews, 44, 51-59.

Raukas, A., Karukäpp, R. 1979. Structure and formation of accumulative insular heights in Estonia. In: Raukas, A. (ed.), Eesti NSV saarkõrgustike ja järvenõgude kujunemine. Valgus, Tallinn, pp. 9-28.

Karukäpp, R. 1997. Gotiglacial morphogenesis in the southeastern sector of the Scandinavian continental glacier. Dissertationes Geologicae Universitatis Tartuensis, 6, 54 pp.

\section{Morphogenetic classification of kame terraces in the Late Nemunas glaciation area of Lithuania}

\author{
Danguole Karmazienè
}

\section{Lithuanian Geological Survey, Lithuania}

The classification presented here is based on investigations of the morphology and structure of kame terraces in the territory of Lithuania. A more extensive classification of the kame terraces in the area covered by the Late Nemunas glaciation in Lithuania requires detailed investigations of the identical glacioaquatic landforms in other regions affected by the same glaciation.

According to the position with respect to a glacier, the kame terraces are classified as: (1) terminoglacial (formed at the glacier edge) terraces, and (2) supraglacial (formed on the glacier surface) terraces.

According to geomorphological location, terraces are classified into: (1) terraces formed by the slopes of the elevations of older glaciation, (2) terraces by the slopes of the tunnelvalleys, (3) terraces along the distal and proximal slopes of marginal ridges, (4) terraces formed within lake basins in elevated areas, (5) terraces in glacier crevasses, melting patches and other cavities, and (6) terraces at the slopes of elevations formed at different stages of deglaciation. Kame terraces may be formed directly, i.e. right on the glacier base, and by inversion, when a terrace projects on the glacier base only after complete melting of the buried ice in the deposits. The structural and textural features of the internal structure of the terraces serve as criteria for attributing them to these different groups.

The internal structure of the kame terraces depends directly on the factors associated with their formation. Usually terraces form as a result of continuous deposition. According to whether terrace sediments were deposited under conditions of flowing or still meltwater, they 
are classified as (1) glaciofluvial terraces, and (2) glaciolacustrine terraces. As a result of the combined action of flowing and still ice meltwaters (3) complex (glacioaquatic) kame terraces can be formed.

According to their morphography, terraces are (1) elementary and (2) composite. The surface of the elementary terraces is smooth and even across almost the whole terrace; commonly it is represented by a flat or slightly occasionally undulating plain. The surface of the composite kame terraces is usually complicated by a great number of alternating positive and negative forms. Isolated kames or groups of kames and isolated eskers or chains are superimposed on a background of the undulating relief. The declensions at the slopes of kames terraces and eskers are filled with lacustrine sediments and peat. The terraces have plentiful glaciokarst kettles and pits. Some kettles are filled in with peat or have turned into small lakes.

The planar configuration of kame terraces is variable with elongated forms or chains of terrace segments being most common. According to the number of levels, the terraces are (1) singly-level or elementary terraces, and (2) multilevel kame terraces.

The terrace topography is typically represented by a flat, slightly undulating or undulating plain often slightly or steeply inclined towards the terrace slope. The surface of the glaciofluvial kame terraces is inclined in the direction of meltwater flow. The initial relief of the terraces has often been transformed by epigenetic processes. The surface has become hummocky, patterned with glaciokarst kettles and pits and partitioned by periglacial gullies. The kettles and pits in the terrace surface usually occur in the distal part near the edge, i.e. in the part of the youngest deposits. In the proximal part of the terrace, pits are fewer since, presumably, the buried ice melted before the end of sedimentation and deposition. Thus, the pits that formed earlier were filled with deposits. Some pits represent small lakes or are filled with peat.

Every kame terrace in its lower part is limited by a well-developed slope representing the old slope of the dead ice. Ice-contact slopes have developed in all deposition/dead ice interfaces. Straight continuous ice contact slopes occur only in isolated areas. Usually, the slopes are meandering or serrated, partitioned by small bogs and declensions, and in places punctuated by hills. The complex, i.e. meandering, serrated and partitioned, slopes reflect the varied ice-marginal geometry of the glacier margin associated with their formation.

\section{The isolation stratigraphy of small lakes in northern Lake Ladoga basin in reconstructions of the Baltic Ice Lake final stage and early Holocene glacioisostatic uplift}

Denis Kuznetsov, Anna Ludikova and Tatyana Sapelko

Institute of Limnology, Russian Academy of Sciences, Russia

Fennoscandia was subject to the large glacioisostatic rebound during the Holocene, and the contemporary uplift rate in the northern parts of the Lake Ladoga basin is still about 1 $\mathrm{mm} / \mathrm{yr}$ (Saarnisto, 2012). Simultaneously, significant level and configuration changes took place in the large palaeo-basins of the Baltic (e.g., Baltic Ice Lake, etc.) and Lake Ladoga, and coastal landforms and sediments of the same transgressive/regressive stage are presently located at different elevations due to the uneven uplift. Palaeolimnological studies of the small lakes sediments can provide an additional source of information on the temporal and spatial differences in water levels and uplift rates in the past. 
During the last decade the palaeolimnological team from the Institute of Limnology at the Russian Academy of Sciences has been carrying out studies of the small lakes in Putsari Island, northern Lake Ladoga (Ludikova et al., 2005, Sapelko et al., 2014). All these small lakes located at different elevations experienced inundation by various large palaeo-basins existed in the Baltic and Lake Ladoga starting from the post-glacial times. The lower part of the sediment sequences from the two uppermost lakes (58 and $49 \mathrm{~m}$ a.s.l.) consists of the varved clays deposited in the huge proglacial basin, the Baltic Ice Lake (BIL), that included Lake Ladoga as its easternmost bay. The transition from varved clays to sandy clays, to sandy and clayish gyttja, and to gyttja, peaty gyttja and finally peat is observed up-core, attributed to the isolation of these small lakes from the large basin in the early Holocene. The organic sedimentation started earlier in the upper lake.

The lakes isolation could result either from the abrupt BIL level drop or gradual glacioisostatic uplift of the area after the BIL regression. According to Björck (2008), the BIL level fell ca. 11700 cal. BP by $25 \mathrm{~m}$ within a few years. The BIL sediments north of Lake Ladoga are presently found at the elevation about $100 \mathrm{~m}$ a.s.l. (Koshechkin and Ekman, 1993). If the isolation of both study lakes is assumed to result from the BIL level drop, the amplitude of the regression is estimated as $40-50 \mathrm{~m}$, given the present lakes' elevation. It is therefore more likely, that at least the lower lake maintained the connection with Lake Ladoga after the BIL regression for some time period. Given the complex topography of the terrain, a narrow and sinuous Ladoga bay could stretch to the central part of the island incorporating the small lake basin in its most distant nook. Both lithological and diatom evidences of such prolonged connection with the large basin are not immediately inferred though, opening the discussion on the interpretation of sedimentary signals of the isolation. Nevertheless, suggesting the lower lake isolation resulted from the glacioisostasy, the reconstructed uplift rate here for the period of 10000-11000 cal. BP is estimated as about $10 \mathrm{~mm} / \mathrm{yr}$. However, the duration and conditions of the formation of the transition units (sandy and clayish gyttja) remain debatable, and therefore the presentation demonstrates only preliminary results of the study.

The research was partly supported by RFBR grant No. 12-05-31353

\section{References:}

Björck, S. 2008. The Late Quaternary development of the Baltic Sea. In: Bolle, H.-J., Menenti, M., Rasool, I. (eds), Assessment of climate change for the Baltic Sea Basin. Berlin, Heidelberg, pp. 398-407.

Kosheckin, B.I., Ekman, I.M. 1993. Golocenovye transgressii Ladozhskogo ozera [The Holocene transgressions of the Lake Ladoga]. In: Davydova, N.N., Koshechkin B.I. (eds.), Evolutsiya prirodnyh obstanovok $i$ sovremennoe sostojanie geosistemy Ladozhskogo ozera. Sankt-Peterburg, Izdatelistvo RGO, s. 49-60 (in Russian).

Ludikova, A.V., Subetto, D.A., Davydova, N.N., Sapelko, T.V., Arslanov, K.A. 2005. Kolebaniya urovnia Ladozhskogo ozera v golocene (na osnove paleolimnologicheskikh issledovaniy oz. Svyatogo Sergiya na o. Putsari) [Change of the Lake Ladoga level during the Holocene reconstructed on the base of the palaeolimnological studies of the Lake Svyatogo Sergiya on the Putsari Island]. Izvestiya RGO, 137(6), 34-41 (in Russian).

Saarnisto, M. 2012. Late Holocene land uplift/neotectonics on the island of Valamo (Valaam), Lake Ladoga, NW Russia. Quaternary International, 260, 143-152.

Sapelko, T.V., Kuznetsov, D.D., Korneyenkova, N.Y., Denisenkov, V.P., Ludikova, A.V 2014. Paleolimnologiya vnutrennikh ozer ostrova Putsari (Ladozhskoe ozero) [Palaeolimnology of the Putsari Island inland lakes (Lake Ladoga)]. Izvestia RGO, in press (in Russian). 


\section{Glacial landforms in the forefield of Múlajökull surge-type glacier, Central Iceland}

Kristaps Lamsters and Jānis Karušs

University of Latvia, Latvia

A lot of Icelandic glaciers are known to surge during a period of tens of years (Björnsson et al. 2003). Ice retreat after these surges in the 20th century has opened up the opportunity to study contemporaneous streamlined bedforms similar to those, which formed beneath paleo-ice streams such as flutes and drumlins. Drumlins have been observed in the several forefields of glaciers in Iceland (e.g. Krüger and Thomsen 1984; Fuller and Murray 2002; Kjær et al. 2003; Schomacker et al. 2014), although they are commonly scattered and in small numbers. The newest observations at the active drumlin field in the forefield of Múlajökull reveal the large number (110) of drumlins formed during recent surges (Johnson et al. 2010; Hilmarsdóttir 2013; Jónsson et al. 2014). These drumlins are 70 to $380 \mathrm{~m}$ in length, 20 to $180 \mathrm{~m}$ in width, and 2 to $10 \mathrm{~m}$ in height (Jónsson et al. 2014), in such a way resembling the Pleistocene drumlins contrary to very small contemporary drumlins found at other locations in Iceland (Krüger and Thomsen 1984).

The Múlajökull is a surge-type outlet glacier that drains the S part of the Hofsjökull ice cap in the central Iceland (Fig. 1A). History of Múlajökull surges are known from 1924, four surges occurred since then within interval of 10-20 years. The last surge took place in 1992, when prominent end moraine was created (Johnson et al. 2010).
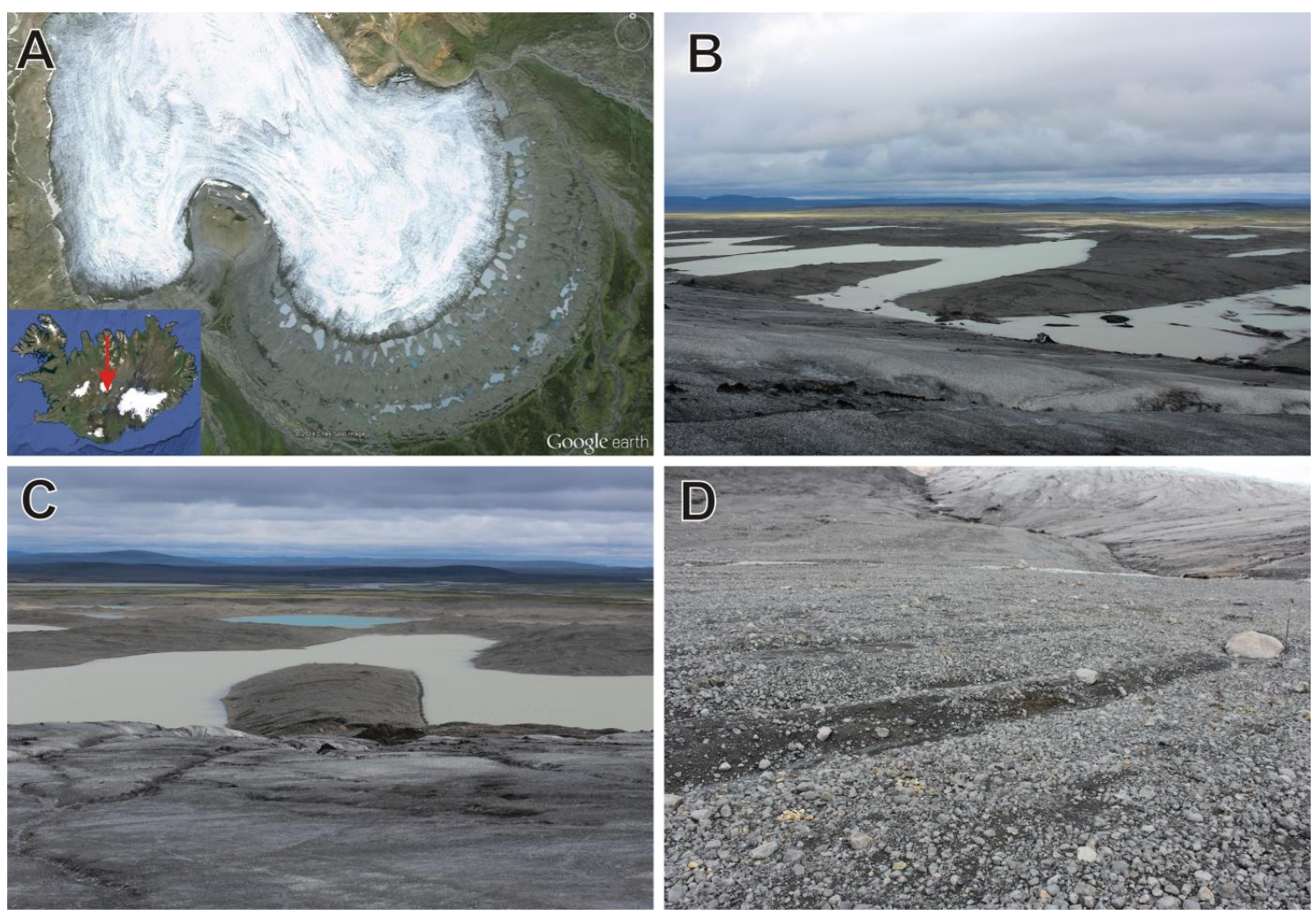

Fig. 1. A: An overview of Múlajökull and its forefield. Note the large amount of lakes and drumlins between them. B: Drumlins with superimposed crevasse-fill ridges. C: Drumlin emerging from the front of Múlajökull. D: Flute with a boulder at the head.

The Múlajökull was firstly visited by the first author of this paper on July, 2013, and overall observations of the distribution of glacial landforms were made. The outstanding 
experience of glacier and drumlin field motivated to come back in 2014, when more detailed investigations were done including measurements of till fabric and glacial striations. We also realized geophysical research by using ground penetrating radar Zond-12e to evaluate radar application possibilities in studies of modern glaciers. The processed data will be presented at the conference of this symposium.

The forefield of Múlajökull and its neighboured Nautahagajökull consists mostly of subglacial landforms as drumlins (Fig. 1B, C) crevasse fill ridges and some flutes (Fig. 1D). Outwash plain covers the most part of the Nautahagajökull forefield, smaller outwash fans and braided rivers occur in front of Múlajökull. End moraines of different age and even lateral moraines are also present. Crevasse fill ridges are very abundant and are frequently superimposed upon drumlins (Fig. 1B). Pushed sediment prows are sometimes found in the front of ploughed boulders, which surface often appears smooth and striated. The surface of Múlajökull in its marginal zone is characterized by radial crevasses, supraglacial channels, moulins, in places it is covered by ablation till.

As reported by Johnson et al. (2010), drumlins in the forefield of Múlajökull are composed of several subglacial till layers (up to 5) often separated by lenses of sorted sediments. Tills were deposited during surges when also drumlins were formed by processes of subglacial till deposition, deformation and erosion. It is supposed that an initiation and growth of drumlins was controlled by the presence of radial crevasses that determined the greater accumulation of till beneath them (ibid.).

\section{References}

Björnsson, H., Pálsson, F., Sigurđsson, O., Flowers, G.E. 2003. Surges of glaciers in Iceland. Annals of Glaciology, 36, 82-90.

Fuller, S., Murray, T. 2002. Sedimentological investigations in the forefield of an Icelandic surge-type glacier: implications for the surge mechanism. Quaternary Science Reviews, 21, 1503-1520.

Hilmarsdóttir, P.H. 2013. Drumlin field at Múlajökull, central Iceland. Master's thesis. Faculty of EarthScience, University of Iceland, pp. 93.

Johnson, M., Schomacker, A., Benediktsson, Í.Ö., Geiger, A.J., Ferguson, A. 2010. Active drumlin field revealed at the margin of Múlajökull, Iceland: a surge-type glacier. Geology, 38, 943-946.

Jónsson, S.A., Schomacker, A., Benediktsson, I.Ó., Ingólfsson, Ó., Johnson, M.D. 2014. The drumlin field and the geomorphology of the Múlajökull surge-type glacier, central Iceland. Geomorphology, 207, 213-220.

Kjær, K.H., Krüger, J., van der Meer, J.J.M. 2003. What causes till thickness to change over distance? Answers from Mýrdalsjökull, Iceland. Quaternary Science Reviews, 22, 1687-1700.

Krüger, J., Thomsen, H.H. 1984. Morphology, stratigraphy, and genesis of small drumlins in front of Myrdalsjökull, south Iceland. Journal of Glaciology, 30, 94-105.

Schomacker, A., Benediktsson, Í. Ö., Ingólfsson, Ó. 2014. The Eyjabakkajökull glacial landsystem, Iceland: Geomorphic impact of multiple surges. Geomorphology, 218, 98-107.

\section{Carbonate cements in glacial sediments: a palaeohydrologic indicator of glacial environment}

Pille Lomp and Maris Rattas

University of Tartu, Estonia

Carbonate precipitates occurring as a cement in primary unconsolidated glacial sediments can precipitate in a variety of geomorphic and hydrologic settings by a variety of mechanisms that lead to their dissolution and reprecipitation. In glacial settings the precipitation of secondary carbonates is mainly a result of inorganic processes, such as regelation, freezing-thawing, evaporation and $\mathrm{CO}_{2}$-degassing. Carbonate cementation has 
been recorded from several places in Estonia, Latvia and Lithuania in glaciofluvial sand and gravel as well as in glaciolacustrine clay complex accumulated during the Late Weichselian deglaciation about 18-12 ka BP. Cementation is observed as laterally continuous layers, vertical piles/patches and small rounded or irregular concretions in otherwise unconsolidated sediments. The cements mainly occur near the top of elevated landforms, either on the surface or a few metres below being covered by glaciolacustrine silty-clayey deposits or till. All cemented zones presently lie well above the modern water table, in the vadose zone.

In coarser gravel facies the cement occurs as a carbonate crust $(<1 \mathrm{~mm})$ around the clast surface, occasionally acting like a glue sticking coarse clasts together. In finer sandy matrix the cement fills almost completely intergranular porespace. The cement is composed of low$\mathrm{Mg}$ calcite and is present as micrite (crystal size $\leq 4 \mu \mathrm{m}$ ), microsparite (from 4 to $10 \mu \mathrm{m}$ ) and sparite (from 10 up to $50 \mu \mathrm{m}$ ) angular equant to elongated rhombohedral, scalenohedral or prismatic calcite crystals. General successions of cementation often demonstrate a variety of textures, which would imply that the formation of cement can take place in changing, even at micro-scale, hydrologic and/or climatic conditions attributed to drainage, fluctuations in the water table and triggering mechanism of precipitation. Precipitation of micritic cement is often considered to be the first stage creating a substrate to successive cementation. The crystal size increases towards the centre of intergranular voids and micritic calcite rims grades into microsparitic and sparitic elongated crystals.

The cementation occurs in conditons of elevated supersaturation of water permeating through sediments. Laterally continuous uniformly cemented layers could refer to formation in conditions of transitional water-level. The precipitation occured mainly in low-energy watersaturated phreatic environment, which is supported by microsparite and sparite calcite crystals prevailingly forming the cement. The formation of vertical cemented piles and patches could be obtained to precipitating from infiltrated water permeating downward through the sediments according to the irregular shape of the piles. In case of very distinct vertically cemented piles should also consider the possibility that the formation was related to vertically upward flowing water. The water could have been under pressure and flowing towards the surface close to the retreating ice margin. Since there are no textural differences between cemented piles and adjacent unconsolidated sediments, seasonally frozen sediments or discontinuous permafrost has been discussed to be a factor influencing the cementation in certain locations forming cemented piles and patches. The formation of small rounded or irregular concretions could also be related to cementation between seasonally frozen sediments sections as a result of thermal regime changes.

The chemistry of cold-climate carbonates is controlled by the isotopic composition of the parent water from which the calcite precipitation occurred and temperature at which the precipitation took place. Thereby it is possible to use these precipitates as a potential indicator of hydrologic conditions and palaeoclimatic proxies. The $\delta^{18} \mathrm{O}$ values $(-12,4$ to $-5,6 \%$ VPDB) of the cement indicate that the parent water does not directly represent the influx of glacial meltwater, but was more influenced by the $\delta^{18} \mathrm{O}$ of groundwater, surface waters and meteoric water. Quite variable $\delta^{13} \mathrm{C}$ values (-17,7\% to $-0,2 \%$ VPDB) of the cement indicate a mixture of various source of carbon and different precipitation mechanism depending on the location and nature of the cemented body. Dissolved atmospheric $\mathrm{CO}_{2}$ or $\mathrm{CO}_{2}$-degassing, dissolution of primary carbonates, evaporation and influence of organic matter are the main factors affecting the $\delta^{13} \mathrm{C}$ composition of the parent water and thereby the precipitated carbonates.

Considering the sedimentary setting, micromorphology and isotopic composition of the studied cement the precipitation of the cement probably occured close to the retreating ice margin or somewhat later in non-glacial contions. The cementation is suggested to be a local 
process presumably controlled by local hydrologic conditions (water-level changes, waterdriving processes, barriers to water flow) at relatively different time period. The isotopic composition shows that solute-bearing waters were enriched in light isotopes, probably somewhat mixed with meteoric and surface waters and affected by atmospheric and biotic factors. Radiocarbon datings of the cement show occasionally the relation with ice-marginal zones and precipitation close to the ice margin or little after the ice retreat, whilst some ages are relatively older/younger compared to the ordinary datings of the ice-marginal positions.

\section{The diatoms of the Baltic Ice Lake: new data from the Lake Ladoga region, the easternmost part of the Baltic Ice Lake}

Anna Ludikova

Institute of Limnology, Russian Academy of Sciences, Russia

Fossil diatom assemblages formed during the Baltic Ice Lake (BIL) stage have been studied in the sediment cores from Lake Ladoga proper and two small lakes located in the island in northern Ladoga, and inundated by the BIL waters in the past. Low diatom concentrations and species richness are among the common features of the BIL sediments in all study sites, although the small lake diatom assemblages still include larger number of taxa compared to those of Lake Ladoga proper.

The presence of marine taxa re-deposited from the Eemian marine sediments was also recorded in the sediment cores. Towards the very top of the BIL sediments, the diatom concentrations and species diversity increase in small lakes. The latter could be attributed to their relative proximity to palaeo-shorelines and greater variety of habitats available in the littoral zone. The diatom assemblages in Lake Ladoga proper, in turn, are dominated by planktonic Aulacoseira islandica throughout the whole time period with only a minor proportion of other planktonic taxa. The pioneer benthic Fragilaria spp flourishing marks the BIL regression in the small-lake sediment sequences. In the Lake Ladoga the diatom richness also increases after the BIL level drop, while the plantkonic to benthic ratio does not demonstrate any change, and the predominance of plantkonic taxa (primarily A. islandica) persists throughout the Holocene.

\section{Upper Dnieper River since LGM: ice damming, glacio-isostatic effects and climatic forcing}

\section{Andrei Panin}

Lomonosov Moscow State University, Russia

This study is aimed at evaluating of the role of glacial influence in the Upper Dnieper River development at sub-latitudinal segment between $54^{\circ} 56^{\prime} \mathrm{N}, 33^{\circ} 13^{\prime} \mathrm{E}$ and $54^{\circ} 45^{\prime} \mathrm{N}, 31^{\circ} 41^{\prime} \mathrm{E}$ with the focus on three main issues: (1) checking the evidences of river damming and glacial lake development, (2) dating of large palaeochannels to prove their glaciofluvial origin, (3) establishing the composite effect of how the proglacial position influenced the valley development and how long the river relaxation period lasted in post-glacial time.

1. The Dnieper River is supposed to have been dammed by the last ice sheet some 20 
$\mathrm{km}$ downstream from Smolensk (Fig. 1). Here the pre-LGM valley bottom, which elevation is 3-4 m lower than that of the present-day floodplain, is traced to the west towards the wide valley occupied now by the Kuprinskoye Lake and the Katynka River. From there the valley turned to SW. The present valley bottom goes parallel few kilometers to the south. The ancient valley bottom is separated from the modern valley by the 20-30-m high horseshoe-like ridge composed of sands and gravels. This ridge has been interpreted as esker. The probable scenario which led to formation of such morphology is that the ice sheet edge stopped right in the valley bottom and pushed the river to the left side of the valley. At the Chekulino village the valley was completely locked, and the river overflowed to an ancient erosion channel (see Fig. 1: wide palaeochannel on the 10-13 m terrace). However in the Early Holocene the river cut through the morain remnant and formed the spillway where the river flows nowadays. The probable reason for this overflow could be an ice jam at the steep turn of the valley formed due to the glacier impact. The age of the spillway formation is established by the OSL date $8200 \pm 440$ (GdTL-1467).

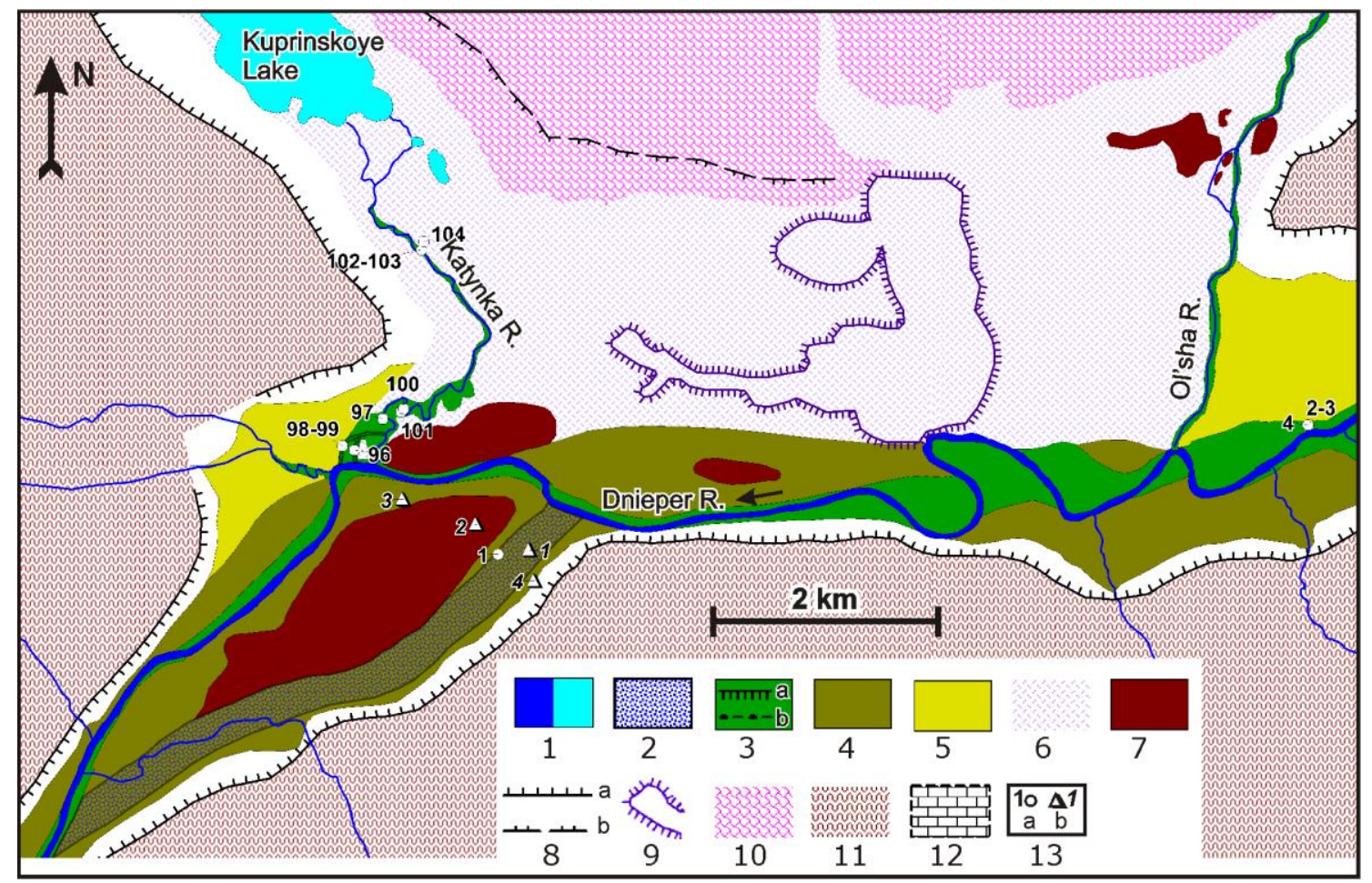

Fig. 1. Geomorphological map of the Upper Dnieper valley at the Katyn' town where it is supposed to have been glacially dammed during LGM.

Legend: 1 - modern hydrographic objects: River Dnieper channel, small rivers, and lakes; 2 - palaeochannels; 3 - 5-9 m floodplain terrace with individual topographic elements ( $\mathrm{a}$ - erosion pits, $\mathrm{b}$ - levees); 4 - 10-13 m loessdevoid terrace (Late-glacial-Early Holocene); 5 - 10-14-m loess-covered terrace (LGM); 6 - alluvial valley bottoms reworked by glaciofluvial processes (LGM); 7 - erosion remnants composed of glacial till of different ages; 8 -valley shoulders and valley sides (a - contemporary, b- pre-LGM, visible through glacial/glaciofluvial sedimentary cover); 9 - glaciofluvial ridges (eskers), LGM; 10 - morain terrain of the Late Valdaian glaciation (MIS 2); 11 - partly reworked morain/glaciogluvial terrain of the Moscovian glaciation (MIS 6); 12 - living space of the Gnezdovo Early Medieval settlement; 13 - location of dated samples $\left(\mathrm{a}-{ }^{14} \mathrm{C}, \mathrm{b}-\mathrm{OSL}\right)$ and their numbers in Panin et al. 2014 (Tables 1,2). Note: elevation of the river terraces is in meters above the river at typical low-water stage.

Sediments of the glacial dammed lake were found at the base of the 10-m terrace at Gnezdovo some $10 \mathrm{~km}$ downstream of Smolensk. They are clayey silts with sand lenses which evidence semi-open character of the water body. Association with the glacial damming is 
supported by absolute chronology of these deposits established by OSL date 21,400 $\pm 2,800$ (GdTL-1238) and ${ }^{14} \mathrm{C}$ date $25,910 \pm 890$ cal BP (GIN-14615) (the latter age is probably overestimated). The elevation range of the lacustrine deposits established in a coring profile across the valley is $\pm 6 \mathrm{~m}$ relative to the modern river. Therefore the lake level was too low to overflow to other basins as it was hypothesized earlier by Kvasov (1979).

2. At the studied 100-km latitudinal segment of the Upper Dnieper valley large braided to gently meandering palaeochannels are found that were usually believed to have been formed by glacial meltwater outflow during LGM. However we produced absolute dating of palaeochannels and related sediments and revealed their Early Holocene age from the very onset of the Holocene to 8,000-9,000 years BP.

Flood flow velocities estimated from alluvium grain size were 1.5 times as great as that of the modern river. Flood discharges estimated from flow velocities and morphological parameters of palaeochannels exceeded the modern mean maximum discharges by 2-2.5 times. Estimated Early Holocene valley slope necessary to maintain the required flow velocities was 3.5 times greater than that of the modern valley. To provide such slope tectonic tilting by $0.20 \%$ was required which was most probably associated with the glacio-isostatic forebulge. Novel is the possibility of the forebulge survival till the Early Holocene while it must have been almost completely collapsed by that time according to existing models. Formation of wide braided palaeochannels was therefore governed by two factors - climatic rise of runoff and allogenic increase of valley slope survived partially from the LGM time. Surprisingly, no traces of LGM and Late-glacial runoff have yet been found. Probably large masses of glacial meltwaters were yielded to the Dnieper valley downstream from the studied segment, through the Berezina and Pripyat' rivers.

3. If the above reconstruction is valid, the glacio-isostatic residual movements still affected the river in the Early Holocene. However the composition of the floodplain demonstrates that the river had already been deepened to the present-day level and acquired the present-day planform by about 6-7.5 cal ka BP when now buried well-developed floodplain soils were formed within the overbank floodplain deposits, and the bed of channel sand was at the level similar to that in the modern channel. In the Middle Holocene the river was slowly forming steep meanders, with acceleration of bank erosion and meander development between 3.5-4.5 cal ka BP, and extreme floods between 2-2.5 cal ka BP that straightened the channel and formed large erosion pits in the floodplain. Period between 2000 (1800) - $800 \mathrm{cal}$ ka BP was characterized by low flood activity, no inundation and formation of mature soil in the floodplain. High flood activity resumed in the LIA with the most severe floods in the $14^{\text {th }}$ century AD.

Research is supported by the Russian Foundation for Basic Research (RFBR), project No. 12-05-01148.

\section{References:}

Kvasov, D.D. 1979. The Late-Quaternary history of large lakes and inland seas of Eastern Europe. Annales Academia Scientarium Fennicae, Series A. III. Geologica-Geographica. Suomalainen Teideakatemia, Helsinki, 127 pp.

Panin, A.V., Adamiec, G., Arslanov, K.A., Bronnikova, M., Filippov, V.V., Sheremetskaya, E.D., Zaretskaya, N.E., Zazovskaya, E.P. 2014. Absolute chronology of fluvial events in the Upper Dnieper river system and its palaeographic implications. Geochronometria, 41 (3), 278-293. 


\title{
Heavy minerals as indicators of the source areas of the sediments in the Toruń-Eberswalde ice-marginal valley, NW Poland
}

\author{
Małgorzata Pisarska-Jamroży ${ }^{\mathrm{a}}$, A. J. (Tom) van Loon ${ }^{\mathrm{a}}$, Barbara Woronko ${ }^{\mathrm{b}}$ and Beata Sternal ${ }^{\mathrm{a}}$ \\ adam Mickiewicz University, Poznań, Poland \\ ${ }^{\mathrm{b}}$ University of Warsaw, Poland
}

Two locations in the Torun-Eberswalde ice-marginal valley and two outwash plains (the Drawa and Gwda sandurs) were investigated for heavy-mineral content (Fig. 1). All deposits formed during the same time (Pomeranian phase of the Weichselian glaciation). The icemarginal valley was fed mainly by streams running over the sandurs in the North, so that the heavy-mineral compositions of the sandurs and the ice-marginal valley are quite comparable. Some material may have come from the East, where the ice-marginal valley was also fed by meltwater streams from the North; some other material must come from eroded bedrock. All waters run westwards in the Torun-Eberswalde ice-marginal valley. The system with a periglacial braided river in this valley was characterised by 'normal' fluvial deposition, affected by solifluction processes, thermal erosion and short fluvial reworking of glacigenic sediments (Pisarska-Jamroży and Zieliński 2011; Weckwerth 2013).

The heavy-mineral composition of the sandur and ice-marginal valley deposits is characterised by a limited number of mineral species. The sandur and ice-marginal valley sediments show comparable heavy-mineral spectra, which suggest a same source of the minerals. The most common minerals on the sandurs are limonites $>$ amphiboles $>$ garnets $>$ opaque rest group > epidote > biotite; in the ice-marginal valley they are opaque rest group > opaque rest group $>$ amphiboles $>$ garnets $>$ epidote $>$ biotite.

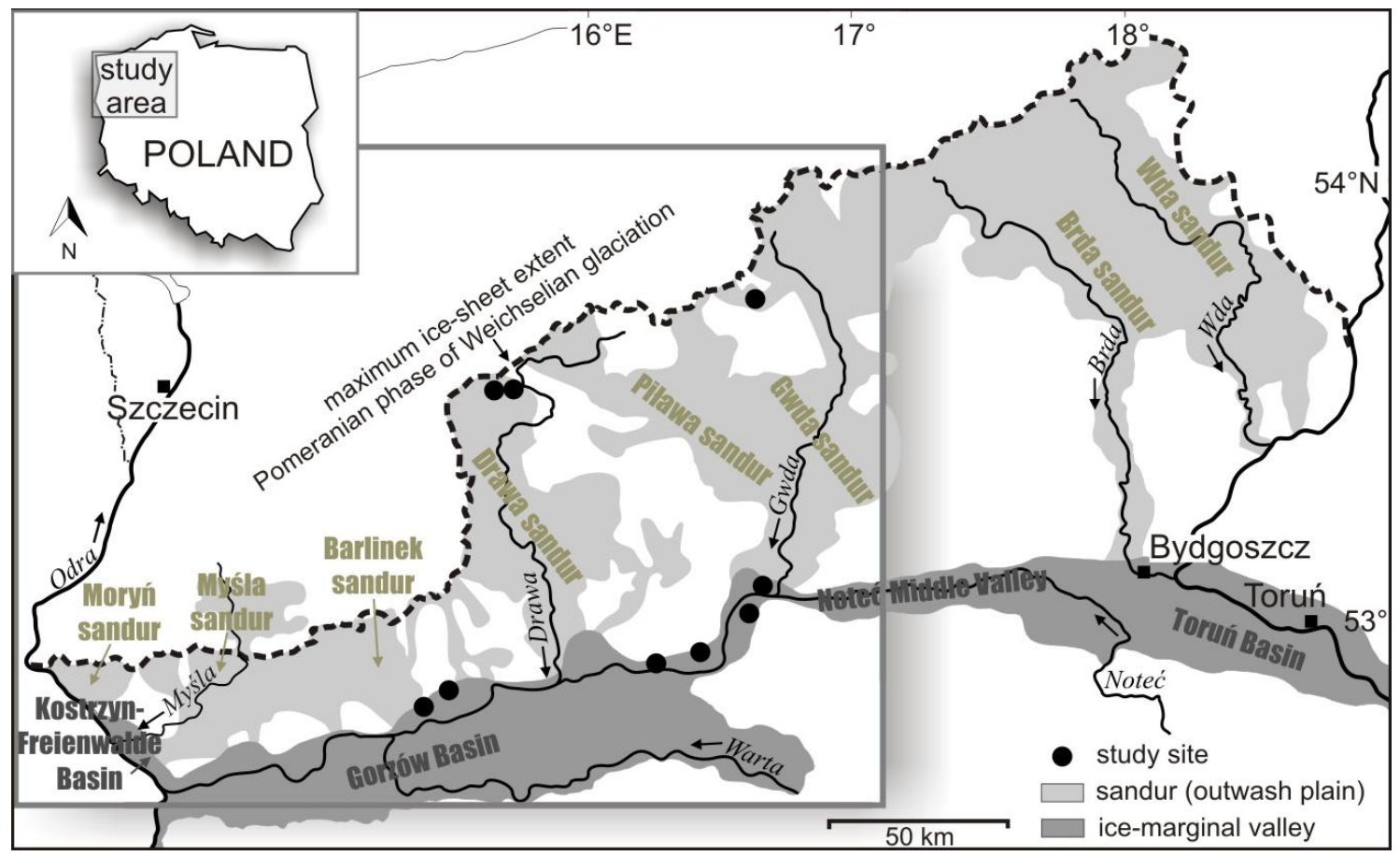

Fig. 1. Location of the study area in NW Poland with schematic position of the sandurs and ice-marginal valley.

The percentages of individual heavy-mineral species as a rule fluctuate more in the samples from the ice-marginal valley than in those from the sandurs. This might be ascribed to the fact that the sandur sediments were enriched only by mineral grains from earlier deposited 
sandurs, whereas the streams in the ice-marginal valley eroded older bedrock and could thus supply other heavy minerals to their sediments.

From a methodological point of view an interesting relationship appears when comparing the proportions of the densest heavies in the group of transparent minerals with those in the group of all minerals (transparent plus opaque minerals). In the group of exclusively transparent heavy minerals, the densest heavies in the sandurs and the icemarginal valley have more or less similar proportions, but - if all minerals are analysed there is a difference between the sandur and ice-marginal valley sediments of $\sim 10 \%$. Heavymineral analysis in both cases (the whole spectrum and the transparent spectrum) thus shows that it is necessary, if reliable conclusions are to be drawn, to analyse also the proportion and composition of the opaques. We suggest therefore that analysis of opaques is required for meaningful interpretations.

The dominance of amphiboles and garnets in both the sandur and the ice-marginal valley samples suggests that the material was mainly derived from a single source: the Palaeozoic and Precambrian rocks in the East Central Baltic (cf. Passchier 2007). The heavy minerals in the ice-marginal valley were additionally slightly enriched by minerals derived from eroded Miocene sediments in the substratum of the ice-marginal valley. No evidence has been found for a supply by southern, extraglacial rivers, so that this source cannot have contributed in any significant amount. This result might be caused by (1) the long distance from possible sources in the South so that minerals from those sources that were not resistant to abrasion disappeared during transport and/or (2) the sediments that were eroded from rocks in the southern source area may have been weathered to such a degree (during the warm Miocene and/or interglacials) that the chemically non-resistant minerals had become so fragile (see Van Loon 2013) that they were completely destroyed during their south-to-north transport, and/or (3) the supply by streams from the South was only marginal.

The work has been financially supported by a grant from the Polish Ministry of Science and Higher Education (research project No. N N307 057540).

\section{References}

Passchier, S. 2007. The use of heavy minerals in the reconstruction of ice-sheet drainage patterns: an example from the edge of the East Antarctic ice sheet. In: Mange, M.A., Wright, D.T. (eds), Heavy Minerals in Use. Developments in Sedimentology, 58, Elsevier, Amsterdam, pp. 677-700.

Pisarska-Jamroży, M., Zieliński, T. 2011. Genesis of a till/sand breccia (Pleistocene, Noteć Valley near Atanazyn, central Poland). Sedimentary Geology, 236, 109-116.

Van Loon, A.J. 2013. The revival of heavy-mineral analysis as a tool for sedimentological research. Geologos, 19, 1-4.

Weckwerth, P. 2013. Procesy fluwialne toruńskiego basenu sedymentacyjnego podczas zlodowacenia wisły [Fluvial processes of the Torun sedimentary basin during the Weichselian glaciation]. Nicolaus Copernicus University Press, Toruń, 205 pp.

\section{Records of natural and human-induced environmental changes in Latvian lake sediments}

Agnese Pujāte, Karina Stankeviča, Anda Dručka, Anda Staškova, Aija Ceriņa, Laimdota Kalniņa and Elīza Kušķe

University of Latvia, Latvia

There is a growing concern about the potential accumulation of heavy metals in lake sediments. This is mainly the result of urban and industrial discordant development over the 
last several decades on sediment composition and sedimentation conditions. Pre-industrial human activity and the impact on the ecosystem is local (Birks 1986; Renberg et al. 1993), but the upper sediment-denominated debt to industrial pollution that spreads through the air and can be recorded in lake sediments, which are sensitive to environment changes.

Lakes in Latvia are under different conditions. Part of them is strongly influenced by human activities, while many lakes are semi-natural and are less affected by anthropogenic impact. The aim of this study is to investigate the lake sediments related to heavy metal pollution. Sediments from four lakes - Lilaste, Velnezers, Pilcine and Ummis were studied by heavy metal analysis, loss on ignition and macrofossil analysis.

Chemical analysis of sediments has been done by atomic absorption spectrometry after acid digestion, and major- and trace element concentrations were determined using an AAnalyst 200 with flame atomization by Perkin Elmer instrument. The finely-ground samples (0.5-1 g) were treated with $25 \mathrm{ml}$ of $50 \% \mathrm{HNO}_{3}$ and $5 \mathrm{ml}$ of $30 \% \mathrm{H}_{2} \mathrm{O}_{2}$. Solutions were boiled at $150^{\circ} \mathrm{C}$ until half of liquid has evaporated, and then $25 \mathrm{ml}$ of $50 \% \mathrm{HNO}_{3}$ were added and boiled at $100^{\circ} \mathrm{C}$. The samples were filtered and diluted to $50 \mathrm{ml}$ (Csuros and Csuros 2002).

Loss on ignition (LOI) analysis of sediments refers to the mass loss of a combustion residue whenever it is heated to high temperatures. The dried (overnight at $105^{\circ} \mathrm{C} 24 \mathrm{~h}$ ) samples of sediments in crucibles are placed in the furnace and kept at $550^{\circ} \mathrm{C}$ for 2 hours and $950^{\circ} \mathrm{C}$ for 2 hours. The percentage of the dry weight lost on ignition can then be calculated according to Heiri et al. (2001).

For macrofossil analysis (remains of plants, invertebrates and macroscopic charcoal), samples with a volume $45 \mathrm{~cm}^{3}$ from $5 \mathrm{~cm}$ thick sediment sections were washed with water through a $250 \mu \mathrm{m}$ sieve, after which the residues were analysed under a light-microscope. Macrofossils were counted and identified according to the reference collections and descriptive manuals (Birks and Birks 2004; Cappers et al. 2006).

Accordingly, total concentrations of 7 heavy metals (including $\mathrm{Cu}, \mathrm{Pb}, \mathrm{Zn}, \mathrm{Cd}, \mathrm{Ni}, \mathrm{Co}$ and $\mathrm{Cr}$ ) have been determined, as well as $\mathrm{Ca}, \mathrm{Mg}, \mathrm{Fe}, \mathrm{K}, \mathrm{Na}$ which originate regarded as naturally from lake sediments. Chemical element $\mathrm{Ca}, \mathrm{Fe}, \mathrm{Mg}$ concentration values increase in lake sediment lower layers what have been influenced by the fact that there is formed Hypnum peat layer, which contains calcium, iron and magnesium. In the Lake Velnezers at the depth interval from $2.45 \mathrm{~m}$ to $2.5 \mathrm{~m}$ Hypnum peat layer has been formed and high values of $\mathrm{Ca}-$ $7069 \mathrm{mg} / \mathrm{kg}, \mathrm{Mg}-1302 \mathrm{mg} / \mathrm{kg}$ were fixed. Content of heavy metals in the upper $25 \mathrm{~cm}$ of the Lake Velnezers sediments significantly increase $(\mathrm{Pb}-137 \mathrm{mg} / \mathrm{kg}, \mathrm{Ni}-15.1 \mathrm{mg} / \mathrm{kg}, \mathrm{Cu}-78.6$ $\mathrm{mg} / \mathrm{kg}, \mathrm{Zn}-535 \mathrm{mg} / \mathrm{kg}, \mathrm{Cr}-25.6 \mathrm{mg} / \mathrm{kg}$ ) which point on industrial pollution. Values of chrome increase in upper part $(0-20 \mathrm{~cm})$ of the Lake Lilaste sediments but the maximal values of chrome have been found at the depth interval $12-14 \mathrm{~cm}$ reaching $22.6 \mathrm{mg} / \mathrm{kg}$. In the Lake Lilaste sediment section iron values is very high in the upper $15 \mathrm{~cm}$ and reach more than $50,000 \mathrm{mg} / \mathrm{kg}$. High iron concentration has been found also in other studied lake sediments, but in less concentration, e.g. in the Lake Pilcine, - up to $10,000 \mathrm{mg} / \mathrm{kg}$, in the upper sediment layer of the Lake Velnezers $-15,000 \mathrm{mg} / \mathrm{kg}$. The concentration of heavy metals varied as follows (in $\mathrm{mg} \mathrm{kg}^{-1}$ ): $\mathrm{Pb} 4.0-35.7, \mathrm{Cu} 4.9-13.5, \mathrm{Zn} 31-69, \mathrm{Mn} 123-228$ in the upper $60 \mathrm{~cm}$ of sediment of the Lake Lilaste.

It is critical to protect lakes from pollution and ensure its sustainability. Among numerous lake sediment pollutants, heavy metals are especially dangerous due to their high toxicity and persistence in the environment. Heavy metals - $\mathrm{Co}, \mathrm{Ni}, \mathrm{Pb}, \mathrm{Cd}$ and $\mathrm{Cr}$ are found in different concentrations in the sediments of lakes Velnezers, Lilaste, Pilcene, Ummis. The highest values are found in the upper sediment layers which probably points on human industrial pollution. In lakes Lilaste and Velnezers concentrations of heavy metals come from 
road transport and air pollution, because there are not large industry activities in direct vicinity of these lakes.

Results of sediment LOI analysis reflect changes in sediments composition of studied lakes related to values of organic matter, carbonates and mineral matter, therefore allow better explain changes in the heavy metal concentrations and distinguish natural and anthropogenic influence in sediments.

Macroscopic remain analysis indicates start and intensification of lake overgrowing. Together with LOI data they reflect fluctuations of water level which can be accompanied also by changes in sediment chemical composition in all studied lakes.

\title{
References
}

Birch, G., Taylor, S., Matthai, C. 2001. Small-scale spatial and temporal variance in the concentration of heavy metals in aquatic sediments: a review and some new concepts. Environmental Pollution, 113, 357-372.

Birks, H.J.B., Birks, H.H. 1980. Quaternary Palaeoecology. Arnold, London, 289 pp.

Burton, A., Baudor, G., Beltrami, M., Rowland, C. 2001. Assessing sediment contamination using six toxicity assays. Journal of Limnology, 60, 263-267.

Cappers, R.T.J., Bekker, R.M., Jans, J.E.A. 2006. Digital seed atlas of the Netherlands. Barkhuis Publishing, Groningen, XXV, 502 pp.

Csuros, M., Csuros, C. 2002. Environmental Sampling and Analysis for Metals. Lewis Publishers/CRC Press, Boca Raton, FL, 450 pp.

Heiri, O., Lotter, A. F., Lemcke, G. 2001. Loss on ignition as a method for estimating organic and carbonate content in sediments: reproducibility and comparability of results. Journal of Paleolimnology, 25, 101110.

Renberg, T., Korsman, T., Birks, H.J.B, 1993. Prehistoric increases in the $\mathrm{pH}$ of acid-sensitive Swedish lakes caused by land-use change. Nature, 362, 824-826.

Rosich, R. S., Cullen, P. 1980. Lake Sediments: Chemical Composition and Some Aspects of Their Formation and Diagenesis. In: Trudinger, P. A., Walter, M. R., Ralph, B. J. (eds.), Biogeochemistry of Ancient and Modern Environments. Springer, Berlin/Heidelberg, 105-115.

\section{The links between Quaternary palaeosurfaces and present surface of south Lithuania}

\author{
Violeta Pukelytè \\ Institute of Geology and Geography, Nature Research Centre, Lithuania
}

The conducted palaeogeomorphological regionalisation of sub-Quaternary surface leads to the following conclusions (Šliaupa 2004; Baltrūnas and Pukelytė 1998): (1) the distinguished palaeogeomorphological regions are of different absolute altitudes, have terraced structure and differ in the texture, structure and age of deposits; (2) the origin, composition and age of watershed deposits covering the palaeogeomorphological regions and the data obtained about the scale of some Quaternary egzogenic (exaration, erosion, etc.) processes showed that Middle Pleistocene morphosculptural watersheds are dominant; (3) the absolute altitude of palaeoincisions of sub-Quaternary surface and the filling material showed that the hydrographic network was strongly modified by neotectonic, exaration and erosion processes whereas later, in the times of Quaternary glaciations and deglaciations, it was partly regenerated.

The top of Dainava (Elsterian 2) formation (till) is strongly inclined from $\mathrm{E}$ to $\mathrm{W}$ and is marked by large amplitude of relative altitudes which correlates with the boundaries of present geomorphological regions (Fig. 1). This is proved by the influence of strongly dissected subQuaternary surface on the present surface, i.e. the inclination in E-W direction 


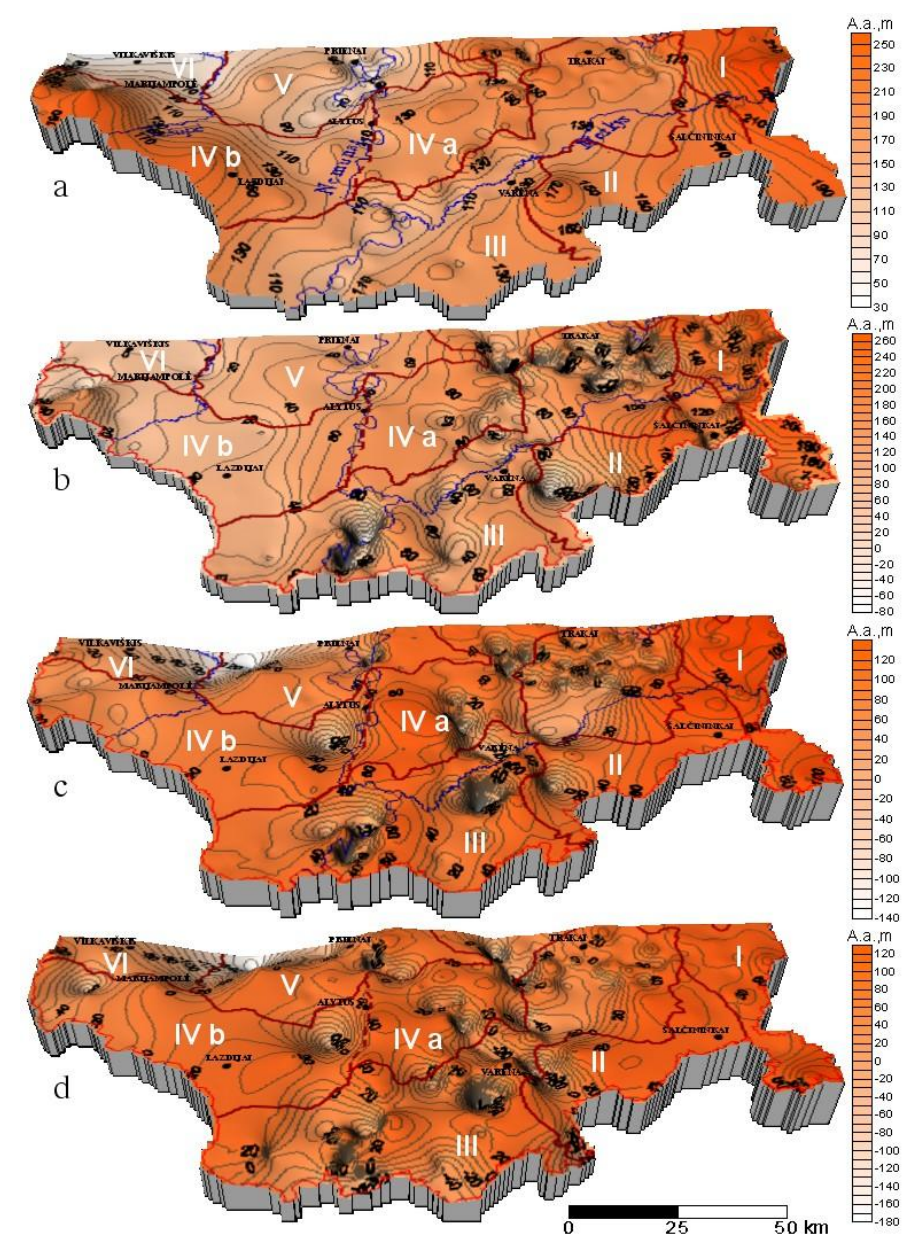

Fig. 1. The 3 D model of compared surfaces was created using SURFER program: a - present surface; $\mathrm{b}$ - top of the Medininkai till; $\mathrm{c}$ - top of the Dainava till; d - sub-Quaternary surface. White lines and indices - geomorphological regions of South Lithuania: I - Medininkai (Ašmena) Upland; II - Eišiškès (Lyda) Plateau; III - South-East (Dainava) Plain; IV a and b - South Lithuanian Plain: IV a - Dzūkai Upland; IV b Sūduva Upland; V - Middle Nemunas Plateau; VI - Lower Nemunas Plain.

The top of the till complex of Dainava formation is strongly dissected: deep palaeoincisions and strongly elevated watersheds. The surface has been smoothed by Žemaitija and Medininkai glaciers. The top of Žeimena (Saalian) formation (Medininkai till) is less dissected and the amplitudes of the relative altitudes in the last glaciation zone are smaller. Larger local elevations of this surface were found only at the Vištytis-Gražiškiai elevation and in the northern part of Dzūkai Upland (Fig. 1). In these areas, the Medininkai till composes part of the surface of the present elevation, which in the Middle Nemunas Plateau and Užnemunė Plain dips into lower buried palaeosurface. This palaeosurface in the Middle Nemunas Plateau is less dissected and gradually elevates in the SE direction till the Eišiškès (Lyda) Plateau.

\begin{tabular}{|c|c|c|c|}
\hline & $\begin{array}{c}\text { Surface } \\
\text { of the top of } \\
\text { Medininkai till }\end{array}$ & $\begin{array}{c}\text { Surface } \\
\text { of the top of } \\
\text { Dainava till }\end{array}$ & $\begin{array}{c}\text { Sub-Quaternary } \\
\text { surface }\end{array}$ \\
\hline $\begin{array}{c}\text { Present } \\
\text { surface }\end{array}$ & $\mathbf{0 , 5 9 1}$ & $\mathbf{0 , 4 4 2}$ & $\mathbf{0 , 3 2 3}$ \\
\hline $\begin{array}{c}\text { Surface } \\
\text { of the top of } \\
\text { Medininkai till }\end{array}$ & & $\mathbf{0 , 6 1 9}$ & $\mathbf{0 , 4 8 5}$ \\
\hline $\begin{array}{c}\text { Surface } \\
\text { of the top of } \\
\text { Dainava till }\end{array}$ & & & 0,751 \\
\hline
\end{tabular}

Table 1. Comparative correlation coefficients of palaeosurfaces and present surface for S Lithuania.

For evaluation of the links between palaeosurfaces and present surface, statistical correlation coefficients of these surfaces were calculated based on the values of absolute altitudes determined in boreholes

(Table 1). The obtained results show strong correlations between the compared surfaces. The values of correlation coefficient for 256 boreholes $(N=256)$ are statistically significant, i.e. higher than or equal with the established critical values: $r_{k r}=0.12$ (when confidence $q=0.05$ ), $r_{k r}=0.16$ (when $q=0.01$ ) and $r_{k r}=0.20$ (when $q=0.001$ ). The binary correlation coefficients of all investigated palaeosurfaces are considerably higher than the established critical values. Thus, this index shows the actual interdependence of the compared surfaces. All correlation coefficients of compared surfaces (calculated based on the data of 256 boreholes) are positive and statistically significant. The linear regression graphs of correlation links between compared surfaces illustrate that the correlation between two points of compared surfaces is close to linear interrelationship. 
Though positive, the correlation link of the present surface with palaeosurfaces loses significance in deeper layers, i.e. it decreases with every older palaeosurface: $r=0.591 \rightarrow r=$ $0.442 \rightarrow r=0.323$. Thus, the weakest correlation link is with the sub-Quaternary surface. The same tendency was determined for the surface of Žeimena formation (Medininkai till): the correlation link decreases in deeper layers. The correlation coefficient of the adjacent surfaces increases with depth: $r=0.591 \rightarrow r=0.619 \rightarrow r=0.751$ (Table 1, Fig. 1).

\section{References}

Baltrūnas V., Pukelytė V. 1998. Lietuvos pokvarterinio paviršiaus paleogeomorfologinis rajonavimas. Geologija, 26. Academia, Vilnius, 105-113.

Šliaupa A., 2004. Prekvartero uolienų paviršius. In: Baltrūnas, V. (ed-in-chief), Lietuvos Žemès gelmiu raida ir ištekliai. Petro ofsetas, Vilnius, p. 254-258.

\section{Chemical characterization of Quaternary groundwaters in Latvia: a case study of trace element content}

Inga Retiķe $e^{\mathrm{a}}$, Jānis Bikšse ${ }^{\mathrm{a}}$, Andis Kalvāns ${ }^{\mathrm{b}}$, Alise Babre ${ }^{\mathrm{a}}$, Gunta Kalvāne ${ }^{\mathrm{a}}$ and Konrāds Popovs ${ }^{\mathrm{a}}$

${ }^{\mathrm{a}}$ University of Latvia, Latvia

${ }^{\mathrm{b}}$ University of Tartu, Estonia

The chemical composition of unconfined groundwater is influenced by all the processes that take part during their formation. Unconfined groundwater chemistry mainly depends on minerals present in the layer of water-bearing rocks, however precipitation can have a significant role on water chemistry in groundwater feeding areas. Most common Quaternary sediments in Latvia are till, silt, sand having varying grain size, clay and peat (Dēliņa 2007).

The aim of this study is to define influence of various Quaternary deposits on trace element levels in groundwaters and to determine processes affecting their chemical composition by analyzing major and trace element data in Quaternary groundwaters in Latvia.

The data from Latvian Environment, Geology and Meteorology Centre databases and previous study (Gosk et al., 2006a, b) were used. Principal component analysis with Varimax rotation was performed to define groups of dependent variables using SPSS 19. A preliminary cleaning of the data set included removal of strong outliers, variables with a poor reproducibility and variables with missing data more than $30 \%$ (including non-detects). The observations below detection limit ( $<\mathrm{DL})$ were substituted with $50 \%$ of DL.

The results from previous studies show that there are no fundamental difference between major element content and water types in groundwaters of various Quaternary sediments (Dēlina, 2007). The main natural processes affecting the quality of confined groundwater are gypsum dissolution and low mineralised groundwater mixing with water of higher mineralisation (Retike et al., 2014). There are no large studies about natural trace element content in unconfined groundwater, therefore it is unknown if the dominant processes forming confined and unconfined groundwaters chemistry are the same.

This study is supported by the European Regional Development Fund project Nr.2013/0054/2DP/2.1.1.1.0/13/APIA/VIAA/007 in Latvia and European Social Fund Mobilitas grant No MJD309 in Estonia.

\section{References}

Dēliņa, A. 2007. Quaternary groundwater in Latvia. Summary of doctoral thesis. Latvijas Universitāte, Rīga, 52 pp. 
Gosk, E., Levins, I. \& Jørgensen, L.F. 2006a. Agricultural influence ongroundwater in Latvia. Danmarks og Grønlands Geologiske Undersøgelse Rapport 2006/85, 98 pp.

Gosk, E., Levins, I., Jørgensen, L.F. 2006b. Shallow groundwater quality in Latvia and Denmark. Geological Survey of Denmark and Greenland Bulletin, 13, 65-68..

Retike, I., Kalvans, A., Babre, A., Kalvane, G., Popovs, K. 2014. Trace element in groundwater used for water supply in Latvia. Geophysical Research Abstracts, 16, EGU2014-10808.

\section{Lithological variability in tills of the Samogitian Upland and surrounding area, Lithuania}

Eugenija Rudnickaitė and Rimantė Guobytė

Vilnius University, Lithuania

The investigated area is the insular accumulative upland ascended as an island surrounded by the Pajūris, Venta, Žiemgala, Nevėžis and Nemunas lowlands. The surface of the upland is greatly contrasting. The slopes of the upland are named Eastern, Western and Northern Samogitian plateau. The Quaternary cover is mostly composed of till beds which represent almost all till formations indicated in Lithuania: Dzūkija, Dainava, Žemaitija, Medininkai and Upper Nemunas. The thickness of Quaternary cover in the upland area varies from 50-100 m up to 150-200 m. The thickest Quaternary (314.2 m) registered in the borehole Vembūtai-93 situated in the central part of the upland. Because the borehole did not reach the sub-Quaternary surface the actual thickness remained unknown (Guobyte 2007).

The geomorphology of the Samogitian accumulative insular upland is specific to the uplands of this type. The upland has two central glacioelevations and the central glaciodepression is situated between them. Glacioelevations are surrounded by peripheral zones, characterized by ice-marginal formations, hills and hilly massifs of glacial and englacial origin (Guobytė 2004, 2007).

There were reconstructed ice lobes and ice tongues in this area during the Last glaciation using the geomorphological method of investigation. Ice lobes of the Riga ice stream are Žiemgala, Venta, Nevėžis, Dubysa; ice tongues: Varduva, Virvyte, Venta. Ice lobes of the Baltic ice stream are Kuršas, Minija, Nemunas; ice tongues: Bartuva, Salantas, Minija, Ančia (Guobytė 2002).

The carbonate analysis was applied to tills from 4 boreholes and 10 outcrops of the Samogitian Upland and surrounding area situated in Lithuania. A calcimeter was used to determine $\mathrm{CO}_{2}$ volume. Carbonate class minerals calcite and dolomite are determined using this method. The carbonates content of sediments was determined for bulk sample. The more detailed description of carbonate analysis is presented in papers Sanko et al. (2008), Kabailiene et al. (2009). For the further comparison of till beds Van der Varden criterion was used.

The Pleistocene tills from 4 boreholes and 10 outcrops on Akmena (Danè), Alanta, Ančia, Akmena, Jūra, Venta, Virvyčia rivers were studied. We determined the mineral composition of carbonates. We are looking for vertical and lateral composition and content variation in tills from different ice lobes and tongues now.

Considering the carbonate material mineral composition, quantities and distribution of minerals as well as the ratio of carbonate minerals it is possible very preliminary to presume that the glacier has advanced as two different ice streams.

The quantity of dolomite is lesser than these of calcite in the upper parts of most the 
outcrops sections studied. It suggests that the bedrocks of glacier were limy. Over this kind of rocks the last Baltic ice stream was advancing. Our data supports the conclusions obtained by the earlier studies, which were based on the coarse-grained fraction of till petrology composition studies.

Calcite and dolomite are the main carbonate class minerals composing the till of Lithuania. There are some differences in the percentage and ratio of these minerals and it depends on the age of till.Some regularity arise e.g. dolomite and calcite ratio of Medininkai glacial moraine is greater than 1 . Thus, the till of that age could serve as lithostratigraphical marker bed.

Based on the obtained data we may presume that the quantities, composition and ratio of carbonate minerals could be used for till lithostratigraphy. Statistical analysis of the data could provide features that might be applied for correlation of till beds. The carbonate analysis data could also be used for palaeogeographical reconstructions (the pathways of glacial advance, centers of glaciations, etc.).

The criterions of Van der Varden enables statistically evaluate the potential application of carbonate analysis data to lithostratigraphy. These assumptions are preliminary and are subjected to revision when more detailed correlation between outcrops and boreholes sections located on different ice lobes and tongues will be done.

\section{References}

Guobytė, R. 2002. Lithuanian surface: geology, geomorfology and deglaciation. Abstract of doctoral dissertation. Vilnius University. Vilnius, $31 \mathrm{pp}$.

Guobyte, R. 2004: Geology and geomorphology of the northern part of the Samogitian Highland. Acta academiae artium Vilnensis, 34, 9-22.

Guobytė, R. 2007. The Samogitian (Žemaičiai) Upland. The Quaternary of Western Lithuania: from the Pleistocene glaciations to the evolution of the Baltic Sea: Excursion guide. The INQUA Peribaltic Group field symposium May 27 - June 02, 2007, Plateliai, Lithuania, pp. 17-18.

Kabailienè, M., Vaikutienè, G., Damušytė, A., Rudnickaitè, E. 2009. Post-glacial stratigraphy and palaeoenvironment of the northern part of the Curonian Spit, Western Lithuania. Quaternary International, 207 (1-2), 69-79.

Rudnickaite, E. 2008. The lithostratigraphy of the western part of Lithuania based on carbonate analysis data. Quaternary of the Gulf of Gdansk and Lower Vistula regions in northern Poland: sedimentary environments, stratigraphy and palaeogeography. International Field Symposium of the INQUA Peribaltic Group, Frombork, September 14-19, 2008. Warszawa, pp. 47-48.

Sanko, A., Gaigalas, A.-J., Rudnickaitè, E., Melešytè M. 2008. Holocene malacofauna in calcareous deposits of Dūkšta site near Maišiagala in Lithuania. Geologija, 50 (4), 290-298.

\section{Cyclic sedimentation pattern in the Lake Veetka, SE Estonia}

\section{Leili Saarse}

Tallinn University of Technology, Estonia

A $1077-\mathrm{cm}$ long sediment core from the Lake Veetka was examined, using loss-onignition (LOI), grain-size distribution and AMS 14C dating in order to determine sedimentation dynamics. The studied core, obtained from the deepest part of the lake, covers approximately 10,450 calibrated years. The sedimentation of organic and mineral matter displays a clear rhythmic deposition pattern with a cycle duration ranging from 200 to 400 years. The cyclic deposition of lacustrine sediments in different parts of the realm has been described (e.g. Battarbee et al. 2001; Skilbeck et al. 2005) and explained by various forcing factors, such as the climate, lake productivity driven by climate variability, solar forcing and 
other controls (Gray et al. 2010).

Several peat bogs in NW Europe have shown cyclic humification in a century to millennia scale caused by changes in hydrological and climatic conditions (Chambers and Blackford 2001). Biological and palaeohydrological data from Männikjärve raised bog (Estonia) also provide evidence of alteration in drier and wetter conditions. Considering a dry and a wet event as one cycle, the cycle lasted about 380 years (Sillasoo et al. 2009).

The current study highlights the linkage between the sedimentary cyclic patterns and climate change, with special attention on the sediments of the Lake Veetka. Veetka $\left(57^{\circ} 43^{\prime} 57^{\prime} \mathrm{N}, 26^{\circ} 28^{\prime} 5^{\prime \prime} \mathrm{E}\right)$ on the Karula Upland is a small (3.3 ha), shallow, outflow lake at 88 $\mathrm{m}$ above sea level, with water depth of $5.5 \mathrm{~m}$ at maximum and $3.9 \mathrm{~m}$ in average. The Karula Upland has hilly mosaic topography formed during the retreat of the last glaciation and melting of the buried ice blocks. The lake catchment mostly consists of glaciofluvial silty and sandy deposits overlying Devonian sandstone. The bottom of the lake is covered by gyttja with the thickness of at least $10 \mathrm{~m}$. Veetka is a eutrophic macrophytic lake with yellow and alkaline water, containing moderate levels of mineral and organic compounds. Palynological data affirm Betula-Pinus as the dominant vegetation in the catchment throughout the Holocene.

Gyttja sedimentation started not later than 10,450 cal yr BP and continued up to the present at the average rate of $1.0 \mathrm{~mm}$ yr-1. The alternation of gyttja with silty gyttja gave the possibility to distinguish between five lithostratigraphical units among which two are highly minerogenic. The basal unit Ve-1 (1180-1577 cm), covering 5600-10,450 cal yr BP, consists of gyttja in which the content of mineral matter continuously increased from 20 to $60 \%$ towards the bottom, while the content of organic matter (OM) decreased from 75 to $35 \%$. Regularly changeable OM and mineral matter form 13 clear cycles with an average pacing of 370 years. In this unit the sediment grain-size was studied along three different cycles. The second unit Ve-2 (1140-1180 cm) differs by the alternation of gyttja with mineral rich bed. This unit deposited between 5200 and 5600 cal yr BP. Mineral matter reached 78\%, carbonates $8-10 \%$, and $\mathrm{OM}$ decreased to $12 \%$. The mineral fraction of the sediment mostly consists of silt and sand fraction, which both vary a great deal. The third unit Ve-3 (840-1140 $\mathrm{cm}$ ) is gyttja, which deposited between 3000 and 5200 cal yr BP. OM content varies mostly between 70 and $80 \%$ and that of mineral matter between 15 and 30\%. Seven cycles with an average pacing of 315 were encountered; however, these were not as regular as in Ve- 1 . The unit Ve-4 covers the core depth 610-840 cm and time window 1250-3000 cal yr BP. The OM content which at the beginning of the unit was $68 \%$, increased steadily to $90 \%$ at $2000 \mathrm{cal} \mathrm{yr}$ BP then stabilized around $80-85 \%$. The clear periodic signal in LOI results is absent, being obviously shadowed by human impact. The topmost unit Ve-5 $(500-610 \mathrm{~cm})$ is similar to unit Ve-3 in its variable LOI, especially in its mineral matter, forming two well developed peaks. The first peak remained between 1250 and $900 \mathrm{cal} \mathrm{yr} \mathrm{BP}$, the second between $500 \mathrm{cal}$ yr BP and the present, with a stable interval between 500 and 750 cal yr BP. OM content varied from 6 to $77 \%$, being at the lowest between 520 and $540 \mathrm{~cm}(200-400 \mathrm{cal} \mathrm{BP})$ that covers the coldest episode of the Little Ice Age. As the carbonate content is very low, the mineral matter variation mirrors that of the $\mathrm{OM}$.

A total of 28 different intervals with rhythmically changing LOI values and the average pacing of 375 years were encountered. It appears that the cyclic sedimentation is associated with the alternation of wet and dry climate conditions that has determined the hydrological balance in the lake and influenced the formation of primary production. In order to verify this hypothesis, the results of this study were compared with different climate proxies and simulations from Estonia and neighbouring countries (Seppä and Poska 2004; Seppä et al. 2009; Laumets et al. 2014). 


\section{References}

Battarbee, R.W., Cameron, N.G., Golding, P., Brooks, S.J., Switsur, R., Harkness, D., Appleby, P., Oldfield, F., Thompson, R., Monteith, D.T., McGovern, A. 2001. Evidence for Holocene climate variability from the sediments of a Scottish remote mountain lake. Journal of Quaternary Science, 16(4), 339-346.

Chambers, F.M., Blackford, J.J. 2001. Mid- and Late-Holocene climate changes: a test of periodicity and solar forcing in proxy-climate data from blanket peat bogs. Journal of Quaternary Science, 16(4), 329-338.

Gray, L.J., Beer, J., Geller, M., Haigh, J.D., Lockwood, M., Matthes, K., Cubasch, U., Fleitmann, D., Harrison, G., Hood, L., Luterbacher, J., Meehl, G.A., Shindell, D., van Geel, B., White, W. 2010. Solar influences on climate. Review of Geophysics, 48, 1-53.

Laumets, L., Kalm, V., Poska, A., Kele, S., Lasberg, K., Amon, L. 2014. Palaeoclimate inferred from $\delta 180$ and palaeobotanical indicators in freshwater tufa of Lake Äntu Sinijärv, Estonia. Journal of Paleolimnology, 51, 99-111.

Seppä, H., Bjune, A.E., Telford, R.J., Birks, H.J.B., Veski, S. 2009. Last nine-thousand years of temperature variability in Northern Europe. Climate of the Past, 5, 523-535.

Seppä, H., Poska, A. 2004. Holocene annual mean temperature changes in Estonia and their relationship to solar insolation and atmospheric circulation patterns. Quaternary Research, 61, 22-31.

Sillasoo, Ü., Poska, A., Seppä, H., Blaauw, M., Chambers, F.M. 2009. Linking past cultural developments to palaeoenvironmental changes in Estonia. Vegetation History and Archaeobotany, 18, 315-327.

Skilbeck, C.G., Rolph, T.C., Hill, N., Woods, J., Wilkens, R.H. 2005. Holocene millennial/centennial-scale multiproxy cyclicity in temperate eastern Australian estuary sediments. Journal of Quaternary Science, $20,327-347$.

\section{Low-impact exploration methods promoting the Green Mining concept in Finland}

\section{Pertti Sarala}

Geological Survey of Finland, Finland

Finland is located in the central part of last glaciated terrain where the glacial sediments cover almost $97 \%$ of the land area. In those conditions, mineral exploration is challenging due to thick glacigenic overburden but also due to large peat land areas and nature reserves. There is increasing demand to develop new applications for exploration. The Green Mining Programme of the Finnish Funding Agency for Technology and Innovation (Tekes) was launched in 2011 to make Finland a global leader of sustainable mineral industry by 2020 and to increase the number of small and medium size enterprises in the mineral cluster in Finland. The Geological Survey of Finland (GTK) has several ongoing projects within this programme and two of these concern new methodologies for sampling, analysis and interpretation of multiple geological, geochemical and geophysical datasets in environmentally sensitive Arctic and Sub-Arctic areas. The projects are Novel technologies for greenfield exploration (NovTecEx, 2012-2014) and Ultra low-impact exploration methods in the subarctic (UltraLIM, 2013-2015).

Both projects include strong development component for the geochemical sampling and analyse methods, decrease analytical costs, and minimise the environmental impact of mineral exploration. Particularly, surficial geochemical sampling and analyse methods are important factors and largely used in mineral exploration in Finland. Different drilling equipments have been tested for the deep till geochemical and heavy mineralogical sampling in the NovTecEx Project. An aim is to get more representative and stratigraphically better controlled samples from till layers, and from weathered bedrock and/or fresh bedrock at the same location. In addition to the conventional geochemical assays, the samples should be collected also for the heavy mineral (e.g. indicator mineral) studies. This means minimum sample size of 5 to 10 litres, i.e. 10 to $20 \mathrm{~kg}$ to get representative samples and enough high sampling accuracy. An ideal sampling layer for the regional till geochemical survey is usually the lowest till bed 
considering the glacial transport and deposition mechanisms. By focusing sampling into this till layer in the whole sampling area, samples are the most comparable to each other. To get basal till samples, several deep drilling equipments and test pits were used for the till sampling.

In the UltraLIM Project, the focus is in the methodological development work to find best possible sampling and analyse methods for the top soil mineral sediments (analyses are based on selective and/or weak leaching), biogeochemistry and snow geochemistry. For testing and comparing different shallow sampling depths and leaching methods several target areas in northern Finland were chosen. They include different types of mineralisation and have variable thickness of the glacigenic overburden. For comparison, the conventional till geochemistry and the portable XRF analyses will be used as a reference.

\title{
Extra short glacial transport - mechanisms and application
}

\author{
Pertti Sarala $^{\mathrm{a}}$ and Vesa Peuraniemi ${ }^{\mathrm{b}}$ \\ ${ }^{\mathrm{a}}$ Geological Survey of Finland \\ ${ }^{\mathrm{b}}$ University of Oulu, Finland
}

Numerous observations of very short glacial transport distances of the till fines and rock fragments were done in northern Finland during last decades. The observations are based on the boulder and pebble countings, and the research of geochemistry and heavy mineral fractions of till together with sedimentological and stratigraphical investigation (Sarala et al. 2007). Those methods are commonly applied in mineral exploration, particularly, when surficial geological methods were used. They were also used as practical exploration tools in the glaciated areas in Northern Hemisphere nearly one hundred of years. Till as a sampling media is very useful due to glacigenic nature and the composition of fresh bedrock surface, pre-glacial weathered bedrock and older sediments. Till debris and fragments are always some distance derived from the source(s) and have dispersed to the direction of ice-flow, giving also a larger and more homogenised indication of source than the bedrock itself.

One of the active-ice moraine formations is the ribbed moraines, which indicate extra short glacial transportation. Several case studies in southern Finnish Lapland were shown the extremely strong glacial quarrying activity and very short transportation of till material from pre-existing Quaternary sediments and the underlying bedrock surface to the top of ribbed moraine ridges (Sarala and Peuraniemi 2007). It is seen in till geochemistry as sharp and strictly bordered metal anomalies in the areas where mineralisation exist in the bedrock. The phenomenon is supported by the distinct surficial boulder fans of which source(s) are almost equal with the halo of mineralised fine material in the upper till. The distance of the highest anomalies can be only some tens of meters from the source like in the case of the Misi, Kuohunki and Petäjävaara targets.

The same phenomenon is seen in the indicator mineral, i.e. heavy mineral investigation (Sarala and Peuraniemi 2007). Short and effective glacial erosion and followed transportation were observed in the upper part of ribbed moraines as well-preserved fresh heavy mineral grains, like sulphide minerals (chalcopyrite, pyrite and magnetite) and gold nuggets. Instead, when the till material has mature composition (rounded, small-size rock fragments and high amount of the fine fraction of till) the preservation of fresh heavy minerals is also weak indicating long glacial transport distance and low reflection to the underlying bedrock. This is usually a case in the lower till(s) in the ribbed moraines. 
Different formation hypothesis were earlier presented for the ribbed moraines suggesting for example compressive sub- or marginal ice flow and basal debris load or marginal push moraine formation. Based on observations in the southern Finnish Lapland, the formation of the ridges is thought to situate at subglacial frozen-thawed boundaries that are time-transgressively moving zone at the inner marginal zone of glacier. The ridge formation is related to extensional and fractional processes that cause brittle fracture of the underlying drift sheet. The formation process is completed by following pressure-controlled freezing-thawing process characterised by active erosion and deposition under moving ice sheet, influenced by still prevailing partially frozen conditions (Sarala 2006).

Another moraine type indicating the very short transportation exists in the central Lapland area. That area locates in the ice-divide zone of Late Weichselian glaciation in central Lapland. Cold-based ground of the glacier has sheltered the pre-existing sediments and helped in preservation of the weathered bedrock in between the glacigenic overburden and fresh bedrock. Only movement of till was happened due to deformation under the ice masses. As an example, there were done a lot of exploration works relating to gold in the central Lapland area. One of the known gold deposits in the Petäjäselkä, Kittilä cause the highest anomalies in the bottom of two to three meters thick till cover only after a few meters transportation. Indication of the same enrichment of gold is seen in the topmost part of till cover about 15 to $20 \mathrm{~m}$ down-ice from the source (Sarala and Ojala 2008). Also somewhat longer (some tens of meters to one hundred of meters) dispersion patterns are common in till geochemistry. This is case also in Mäkärä, in the northern part of Sodankylä municipality, where gold and REE anomalies (caused by the haematite-quartz veins) are seen in the till geochemistry after 10 to $50 \mathrm{~m}$ distance from the source, having about 100 to $120 \mathrm{~m}$ secondary halo at maximum (Sarapää and Sarala 2013).

\section{References}

Sarala, P. 2006. Ribbed moraine stratigraphy and formation in southern Finnish Lapland. Journal of Quaternary Science, 21(4), 387-398.

Sarala, P., Rossi S., Peuraniemi V., Ojala, V.J. 2007. Distinguishing glaciogenic deposits in southern Finnish Lapland: implications for exploration. Applied Earth Science (Trans. Inst. Min. Metall. B), 116(1), 22-36.

Sarala, P., Ojala, V.J. 2008. Chaper 1: Implications of complex glacial deposits for till geochemical exploration: Examples from the central Fennoscandian ice sheet. In: Stefánsson, Ó. (ed.), Geochemistry Research Advances, Nova Publishers, pp. 1-29.

Sarala, P., Peuraniemi, V. 2007. Exploration using till geochemistry and heavy minerals in the ribbed moraine area of southern Finnish Lapland. Geochemistry: Exploration, Environment, Analysis, 7(3), 195-205.

Sarapää, O., Sarala, P. 2013. Rare earth element and gold exploration in glaciated terrain - example from the Mäkärä area, Northern Finland. Geochemistry: Exploration, Environment, Analysis, 13, 131-143.

\section{Stratigraphy of Quaternary deposits, Sheet P-39 (Syktyvkar)}

Lyudmila P. Semenova ${ }^{a}$, Andrey V. Stepunin ${ }^{\mathrm{a}}$, Anton V. Maksimov ${ }^{\mathrm{a}}$ and

Tatyana I. Marchenko-Vagapova ${ }^{\mathrm{b}}$

${ }^{\mathrm{a}}$ A.P.Karpinsky Russian Geological Research Institute (VSEGEI), Russsia

${ }^{\mathrm{b}}$ Institute of Geology Komi Science Centre, Ural Branch of Russian Academy of Sciences, Russia

Map of Quaternary deposits has been made in 2011-2013 as part of works in compiling the authors' version of the State geological map, Sheet P-39 (Syktyvkar) at a scale of $1: 1,000,000$.

The Quaternary deposits of Sheet P-39 were first studied using OSL method, age 
determinations were carried out at the Institute of Geology at Tallinn Technical University. To date, third of the analysis results has been received, so further refinement of the age of the sediments is possible. In addition, palynological analysis (Komi Institute of Geology, NTs UrO RAS), granulometric 19-fractional analysis, radiocarbon age determinations (CL FGUP VSEGEI) were accomplished to ground the genesis and age of deposits. Results of mineralogical, geochemical, petrographic, diatom, foraminifera and other analyzes obtained during earlier studies were used in the differentiation of sediments.

Four major areas - Mezen River Basin, Vychegda and Luza rivers basins, Izhma River Basin, Kama and Veslyana rivers basin have been identified based on the conditions of formation, stratigraphic volume, and time of formation of the deposits (Fig. 1). Quaternary deposits are represented by a wide range of continental sediments of different age and genesis, among which there are Pleistocene and Holocene deposits (Fig. 2). On most of the area, the thickness does not exceed $60 \mathrm{~m}$, maximum, up to $235 \mathrm{~m}$

Lower Neopleistocene unit is represented by the Vishersky and Pomusovsky horizons. The former encompasses alluvium and limnium, the latter, the moraine and glacial-lacustrine deposits. The age of the Vishersky deposits is confirmed palynologically; according to Fish's conclusion, spore-pollen spectra are typical of interglacial epoch and identified with those of the lower unit. The glacial genesis of the Pomusovsky horizon deposits is confirmed lithologically, from the variety of clasts (petrographically) and organic residues (based on composition and age).

Sediments of the Chirvinsky horizon and the Timan-Ural superhorizon, which includes the Pechora, Rodionovsky, and Vychegodsky horizons, are assigned to the intermediate unit of the Neopleistocene. The Chirvinsky horizon is represented by alluvial and undifferentiated alluvial and lacustrine deposits. Spore-pollen assemblages are typical of the lowermost Middle Neopleistocene. Diatoms indicate freshwater conditions of sediment formation (authors of the conclusions are V.M. Smirnov, E.I. Loseva). There are diatoms, which are known as fossils only from the Quaternary.

Pechora and Vychegodsky horizons are glacial complexes, the Rodionovsky horizon that separates them is interglacial. According to numerous analyzes of aqueous extract, moraine clay loam of the Pechora horizon is characterized by hydrocarbonate calcium and magnesium type of salinization with participation of sodium sulfates and chlorides that indirectly testifies to the continental genesis of the sediments. According to petrographic studies it have been identified that petrographic composition of clastic material of the moraine is dominated by Timan-habitus rocks and "local" sedimentary rocks, in the absence of igneous and metamorphic rocks of the Fennoscandian provenance area.

In the palynological spectra of the alluvial, limnic-alluvial deposits of the Rodionovsky horizon, Pisea sect. Omorica is present that confirms the Middle Neopleistocene age of the sediments.

Deposits of the Vychegodsky horizon that occupy most of the area are relief-forming. The formation of the Vychegodsky deposits is a result of development of two streams of ice Scandinavian and Novaya Zemlya. This is clearly seen on the map of Quaternary deposits in orientation and configuration of marginal rock complexes. Numerous marginal deposits horseshoe-shaped in plan have been identified in the course of work. Complicated interaction of ice masses of different ages propagating from the north-west and north-east is clearly seen.

The upper unit is composed of deposits of the Sulinsky horizon and Nenetsky superhorizon, which includes the Laisky, Byzovsky, and Polyarny horizons. The formation of terraces in the Vychegodsky and Izhemsky areas followed the same scenario: third terraces 
above the flood-plain formed during the Sulinsky and Laisky time, second ones - during the Byzovsky and Polyarny time, and first terraces appeared during the Late Polyarny time through the Early Holocene. In the Kama River Basin, second terrace above the floodplain formed during Sulinsky and Laisky time, and the first one, during Byzovsly and Polyarny time. It should be noted that the age of the terraces in this work is given in accordance with the ideas of previous authors. We accomplished their geochronological study, but the results are not obtained yet. According to geochronological data obtained by the authors, in the Mezensky zone, the third terrace above the floodplain formed during Polyarny time, the second one, during the Late Polyarny -Early Holocene time, and the first terrace formed during the Holocene.

The Holocene is represented by alluvium of the riverbed and floodplains, palustral and limnic deposits. Holocene deposits are well studied palynologically and geochronologically.

\title{
References
}

Andreicheva, L.N. 2002. Pleistocene of European North-East. Yekaterinburg, RAS Uralian Division, 322 p.

Lavrov, A.S., Potapenko, L.M. 2012. Neopleistocene of the Pechora Lowland and West Timan area (stratigraphy, paleography, chronology). Moscow, $191 \mathrm{p}$.

Semenova, L.R., Parmuzin, N.M. 2013. Report "Compiling a set of present-day geological base, scale 1:1,000,000, sheet P-39-Syktyvkar”.

\section{Palaeovegetation changes recorded by macroscopic fossil investigation data from Lake Ummis and Lake Mazais Ungurs sediments, Latvia}

\author{
Anda Staškova, Aija Ceriņa, Agnese Pujāte and Laimdota Kalniņa
}

University of Latvia, Latvia

The results of the study provide insight of paleovegetation changes according to the macrofossil investigation data from the sediments of lakes Ummis and Mazais Ungurs.

The lake Ummis $\left(57^{\circ} 09^{\prime} 56^{\prime \prime} \mathrm{N} 24^{\circ} 19^{\prime} 58^{\prime \prime} \mathrm{E}\right)$ is located in the Rigava Plain of the Latvian Coastal lowland on the elevation $3.5 \mathrm{~m}$ a.s.l. It is approximately $4 \mathrm{~m}$ deep, isolated lake, with flat shores and sandy bottom. The Lake Mazais Ungurs (57 $\left.19^{\prime} 58^{\prime \prime} \mathrm{N} 25^{\circ} 03^{\prime} 54^{\prime \prime} \mathrm{E}\right)$ is of glacial origin. It is $5 \mathrm{~m}$ deep, located at an elevation of $69 \mathrm{~m}$ a.s.l. in the Augstroze Interlobate High of the Idumeja Upland, north-central Latvia. The bed of both lakes are partly is filled up with gyttja. Ecosystems of lakes Ummis and Mazais Ungurs are endangered because of anthropogenic impact. Therefore, it is important to investigate the macroscopic fossils from the lakes sediments with aim to reconstruct the vegetation composition and sediment accumulation condition changes during the lake development. Data of these studies are necessary to better understand how to manage and find the best methods how to protect the lakes because of importance to protect some very rare aquatic plant species growing there. Especially top-priority species are Isoëtis lacustris L. and Lobelia dortmanna L. which reproduction and population amount are mainly determined by the lake location, water and sediment chemistry (Smolders et al. 2002).

A 220-cm-long sediment core was collected from the Lake Ummis and a 555-cm-long sediment core from the Lake Mazais Ungurs. Samples from the upper sediment layer (50-60 $\mathrm{cm}$ ) were collected with a plastic tube fitted with piston equipment. More consolidated lake sediments were sampled by Russian type corer with $1 \mathrm{~m}$ long camera.

At the laboratory $1 \mathrm{~m}$ long sediment monoliths were subsampled by $5 \mathrm{~cm}$ interval for plant macrofossil analysis. The volume of each subsample was approximately $50 \mathrm{ml}$. 
Identification of the plant macroscopic fossils was based on available reference materials (Cappers et al. 2006; Katz et al. 1965). Loss on ignition (LOI) method was applied in order to estimate content changes of organic and carbonate matter in the sediments that show fluctuations in sedimentation conditions and are useful for macroscopic fossil data interpretation. For the loss on ignition (LOI) analysis the sampling interval was $1 \mathrm{~cm}$. The moisture of the sediments was determined after drying it at $105^{\circ} \mathrm{C}$. The content of the organic and carbonate matter was analyzed by ashing the samples sequentially at $550^{\circ} \mathrm{C}$ for $4 \mathrm{~h}$ and at $900^{\circ} \mathrm{C}$ for $2 \mathrm{~h}$ (Heiri et al 2001).

The study results obtained from fieldworks (coring, sediment description), plant macrofossil and loss on ignition (LOI) analysis allow to conclude that changes of aquatic plant macroscopic fossil composition in the sediments of both lakes are directly affected by the changes of the lake water $\mathrm{pH}$ values. The appearance of I. lacustris in sediments of the Lake Mazais Ungurs and also L. dortmanna in sediments of the Lake Ummis coincides with the appearance of wood charcoal in sediment layer which may be a reflection of the fire impact on development of these species.

Changes in the lake catchment area, such as forest fires and anthropogenic activities like forest clearance and agriculture, typically increase and enlarge the general rate of erosion and sediment transportation into the lakes. Wood charcoal in the Lake Mazais Ungurs sediments may be a reflection of the impact of human activities on I. lacustris development, because in the north of the lake is located national protected archaeological monuments - the Ureles hillfort and the ancient burial ground Zalkalni, but wood charcoal in the Lake Ummis sediments may be a reflection of the forest fires.

The plant macroscopic fossil and loss on ignition (LOI) data showing a remarkable increase in I. lacustris megaspore values is likely to be related to increased mineral matter input into the lake due to more intensive erosion and the consequent accumulation of mineral mater on the lake bottom. It makes conditions more favourable for the growth of Isoëtes. Their largest stands in the Lake Mazais Ungurs were distributed when the content of organic matter in sediments was $41 \%$. In the result of mineral matter inflow in the Lake Ummis has been formed $14 \mathrm{~cm}$ thick fine grained sand layer which promoted disappearance of Potamogeton pusillus.

The changes in the aquatic plant (Najas flexilis, Najas marina, Isoëtes lacustris, Potamogeton pusillus, Potamogeton natans, Scirpus lacutris, Typha) and wetland plant (Carex, Lycopus europaeus, Juncus bulbosus, Comarum palustris) composition point on water level changes in the lakes.

\section{References}

Cappers, R.T.J., Bekker, R.M., Jans, J.E.A. 2006. Digital seed atlas of the Netherlands. Barkhuis Publishing, Groningen, XXV, 502 pp.

Heiri, O., Lotter, A. F., Lemcke, G. 2001. Loss on ignition as a method for estimating organic and carbonate content in sediments: reproducibility and comparability of results. Journal of Paleolimnology, 25, 101110.

Katz, N.Y., Katz, S. V., Kipiani, M. G. 1965. Atlas and keys of fruits and seeds occurring in the Quaternary deposits of the U.S.S.R. Academy of Sciences of the U.S.S.R, Commission for Investigations of the Quaternary period. Nauka, Moscow, 367 pp. (In Russian)

Smolders, A.J.P., Lucassen, E.C.H., Roelofs, J.G.M. 2002. The isoetid environment: biogeochemistry and threats. Aquatic Botany, 73, 325-350. 


\section{Freshwater travertines from NW Russia - terrestrial archives of paleoenvironmental information}

Eriks Tabuns $^{\mathrm{a}}$, Kathrine Kuksa ${ }^{\mathrm{a}}$, Mikhail Nikitin ${ }^{\mathrm{b}}$, Snezhana Levchenko ${ }^{\mathrm{a}}$, Jonathan Baker ${ }^{\mathrm{c}}$ and Vasiliy Grigoriev ${ }^{\mathrm{a}}$

${ }^{a}$ St.Petersburg State University, Russia

${ }^{\mathrm{b}}$ Herzen State Pedagogical University

${ }^{\mathrm{c}}$ University of Nevada Las Vegas, USA

Holocene freshwater travertines are widely developed in northwestern Russia as well as in other countries of Baltic region. Many peculiarities of these formations have been used to evaluate paleoclimate and postglacial tectonic activity (Soligo et al. 2002, Baker et al. 2013).

Radiocarbon, 230U/Th isotopic chronology, pollen, ostracoda stratigraphy, stable isotopes of carbon and oxygen, and trace-element geochemistry are the main geological tools to elucidate freshwater travertine (meteogenic tufa) formation during the postglacial history of Northern Europe. The use of elemental geochemistry is more rare, however, and typically restricted to major cations ( $\mathrm{Ca}, \mathrm{Mg}$, and $\mathrm{Sr}$ ). In this study, we employ multielemental geochemical analysis to elucidate the environmental conditions under which freshwater travertines form. We studied a 2-meter cross section of the Pudost travertine from the Izhora plateau (NW Russia), which is the largest carbonate massif in this site. It is $2.5 \mathrm{~km}$ in length and $300 \mathrm{~m}$ wide, with a maximal reported thickness of 7.6 meters.

It was previously shown that 230U/Th and radiocarbon dating (Nikitin et al. 2011) constrains the Pudost freshwater travertine formation to 6.8 - $9.5 \mathrm{ka}$ (Early-Middle Holocene). Carbon-isotope data indicate the meteogenic origin of travertine, while increasing $\delta 180$ from $13 \%$ to $-11 \%$ is consistent with climatic warming during this period (Baker et al. 2013).

Multidimensional statistical analysis shows that $67 \%$ total variance of 16 elements in 72 samples can be explained by two main factors. Titanium has the maximum loading on the first factor and evidently demonstrates the clastogenic identity of these multidimensional parameters (Fig. 1).

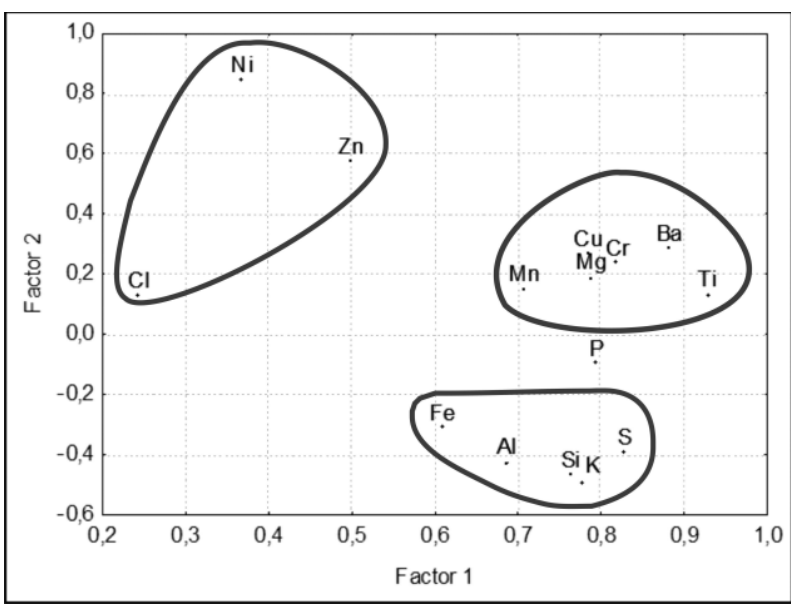

Fig. 1. Distribution of analyzed elements of Pudost travertine in the loading space of the first two factors.

There is moderate correlation between factor scores, trace element data (especially $\mathrm{K}, \mathrm{Si}, \mathrm{Ti}, \mathrm{Al}, \mathrm{P}$ ), and changes in the oxygenand carbon-isotope values (Fig. 2). However, the most striking feature is the distribution of Fe, which clearly divides the studied section into two parts.

The lowermost $100 \mathrm{~cm}$ of travertine are characterized by a high and rather variable Fe signal, whereas the uppermost 96 $\mathrm{cm}$ reveal a low and practically uniform distribution of this element (with one deviation at 180 $\mathrm{cm}$ level). We suggest that these peculiarities are connected with changes in the Early Holocene lacustrine environment, inferred also from the investigation of subfossil ostracods in freshwater tufa from the Varangu section of northern Estonia (Sohar and Meidla 2010). Evidently, variations in the Fe concentration of travertine reflect the "lake evolution from a deep oligotrophic lake to an overgrown lake basin in the Varangu area", as well in the 
neighboring Izhora plateau with respect to the Pudost paleolake.

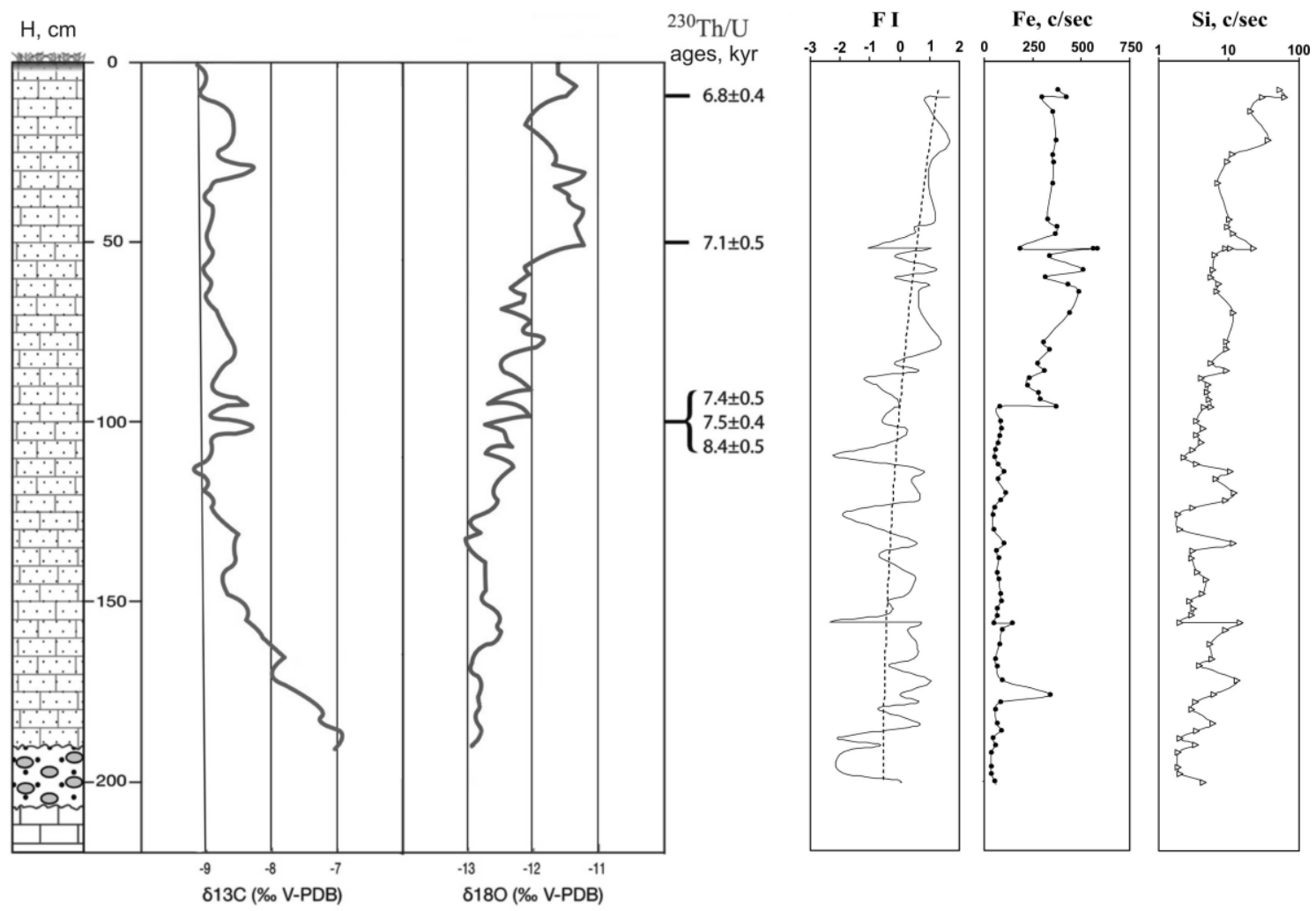

Fig. 2. Distribution of $\delta^{18} \mathrm{O}, \delta^{13} \mathrm{C}$ and some elements through the Pudost travertine cross section. F I - factor I loadings.

The geochemistry of trace elements in travertines thus provides additional important information regarding the response of paleolake systems to Holocene climate changes. To understand this response better and improve paleoenviromental reconstructions, more attention should be devoted to the polyvalent (Fe, V, Mo, Mn, U, Eu, Ce) elemental geochemistry of such formations.

\section{References}

Baker, J., Lachniet, M.S., Nikitin, M.Yu. 2013. The occurrence of calcareous tufa (meteogene travertine) on the Izhora plateau, Northwestern Russia. Paper No. 364-13. Geological Society of America Abstracts with Programs, 45(7), 818.

Nikitin, M.U., Medvedeva, A.A., Maksimov, F.E., Kuznetsov, V.Yu., Zherebtsov, I.E., Levchenko, S.B., Baranova, N.G. 2011. The origin and the geological age of the travertine-like carbonates of the Pudost massif. Journal "Society. Environment. Development" ("TERRA HUMANA”), 2011(4), 231-236.

Sohar, K., Meidla, T. 2010. Changes in the Early Holocene lacustrine environment inferred from the subfossil ostracod record in the Varangu section, northern Estonia. Estonian Journal of Earth Sciences, 59(3), 195206.

Soligo, M., Tuccimei, P., Barberi, R., Delitala, M.C., Miccadei, E., Taddeucci, A. 2002. U/Th dating of freshwater travertine from Middle Velino Valley (Central Italy): paleoclimatic and geological implications. Palaeogeography, Palaeoclimatology, Palaeoecology, 184, 147-161. 


\section{Investigation of stable isotopes and diatom assemblages - a key for paleoenvironmental reconstruction, Curonian lagoon, Lithuania}

Giedrè Vaikutienè ${ }^{\mathrm{a}}$, Raminta Skipityte ${ }^{\mathrm{b}, \mathrm{c}}$, Jonas Mažeika ${ }^{\mathrm{b}}$, Tõnu Martma ${ }^{\mathrm{d}}$, Andrius Garbaras ${ }^{\mathrm{c}}$ and Rūta Barisevičiūtè

${ }^{\mathrm{a}}$ Vilnius University, Lithuania

${ }^{\mathrm{b}}$ Nature Research Centre, Lithuania

${ }^{\mathrm{c}}$ Center for Physical Sciences and Technology, Lithuania

${ }^{\mathrm{d}}$ Tallinn University of Technology, Estonia

Diatoms are unicellular algae which spreads in water and its assemblages depend on ecological conditions (depth, salinity, $\mathrm{pH}$, trophic status) of the basin. Alterations of diatom species composition in the sediment sequence reflect paleoenvironmental changes in the basin. Exchange of brackish (from Baltic Sea) and fresh waters (mainly river outflow) masses via the Klaipeda Strait is very important and distinct in the Curonian Lagoon. Diatom and stable isotope (both nitrogen and carbon) analyses are demonstrative methods which enable to reveal environmental changes in the paleobasin and discover possible reasons predetermined these changes.

Diatom and stable isotope ( $\mathrm{N}$ and $\mathrm{C}$ ) analysis were applied for the bottom sediment core (length $60 \mathrm{~cm}$ ) from the southern part of the Lithuanian aquatory of the Curonian Lagoon $\left(55^{\circ} 22^{\circ} 12^{\prime \prime} / 21^{\circ} 05^{\circ} 11^{\prime c}\right)$. The topmost part of sediment sequenece $(0-40 \mathrm{~cm})$ is composed of fine aleuritic mud and the lower part $(40-60 \mathrm{~cm})$ - coarse aleuritic mud. The sediment column was subdivided into $1 \mathrm{~cm}$ samples. Stable nitrogen isotope ratio $\left(\delta^{15} \mathrm{~N}\right)$ was determined from organic matter of the samples and stable carbon isotope ratio $\left(\delta^{13} \mathrm{C}\right)-$ from carbonaceous matter.

Diatoms. Coarse aleuritic mud (40-60 cm) was deposited in 1940-1970. Prevail (up to $60 \%$ ) freshwater epiphytic (Fragilaria inflata et var. istvanfyi, Fragilaria sp., Martyana martyi) diatoms, planktonic (Stephanodiscus rotula, Aulacoseira islandica, A. granulata) makes smaller part of total diatom sum (Fig. 1). Brackish diatoms compose only 5\% of total diatom sum. Prevailing freshwater epiphytic diatom species indicate sedimentation in the shallow environment of the freshwater lagoon with dominance of fresh water inflow from rivers.

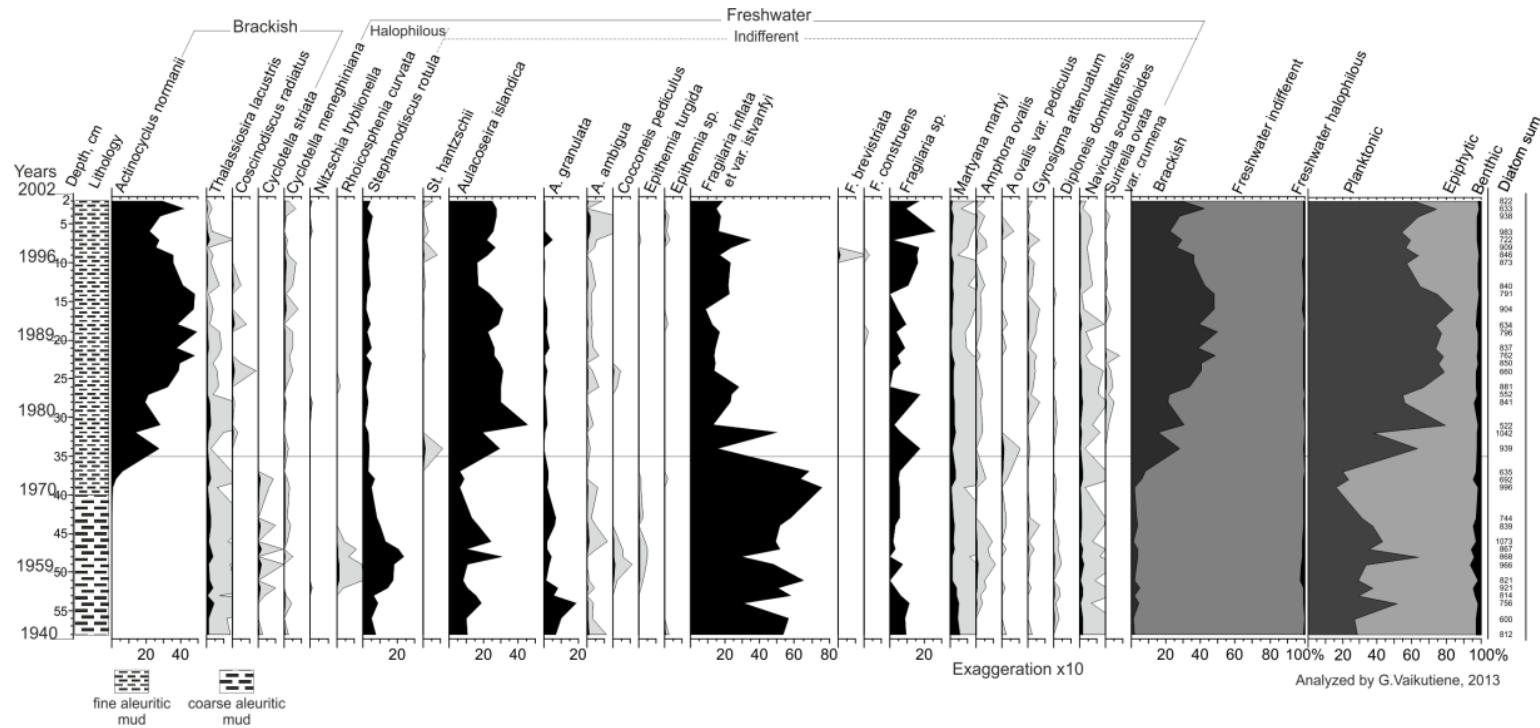

Fig. 1. Prevailing diatom species in the sediment sequence of Curonian Lagoon. 
Accumulation rates increased begining from 1970. At the depth 0-40 cm (fine aleuritic mud, accumulated in 1970-2002) dominate planktonic freshwater (Aulacoseira islandica) and epiphytic (Fragilaria inflata et var. istvanfyi) diatoms. Brackish diatoms make up to $50 \%$ (Actinocyclus normanii increased to $47 \%$ ) of total diatom sum. Actinocyclus normanii is widespread in the coastal area of the Baltic Sea (Snoeijs and Vilbaste 1994). The Klaipeda Strait was dredged up to $14 \mathrm{~m}$ during 1982-1983. Brackish water annual inflow from the sea had enlarged by $24.6 \%$ (Jakimavičius and Kriaučiūnienè 2011). According to diatoms, the dredging of the strait possibly had a great influence for the brackish water distribution in the investigated area.

Stable isotopes. Analyzing relationship between $\delta^{13} \mathrm{C}$ and $\delta^{15} \mathrm{~N}$ values the negative correlation is observed (Fig. 2). The upper part of the interval $(0-35 \mathrm{~cm})$ has higher stable nitrogen values and lower stable carbon isotope values relative to lower part of the interval

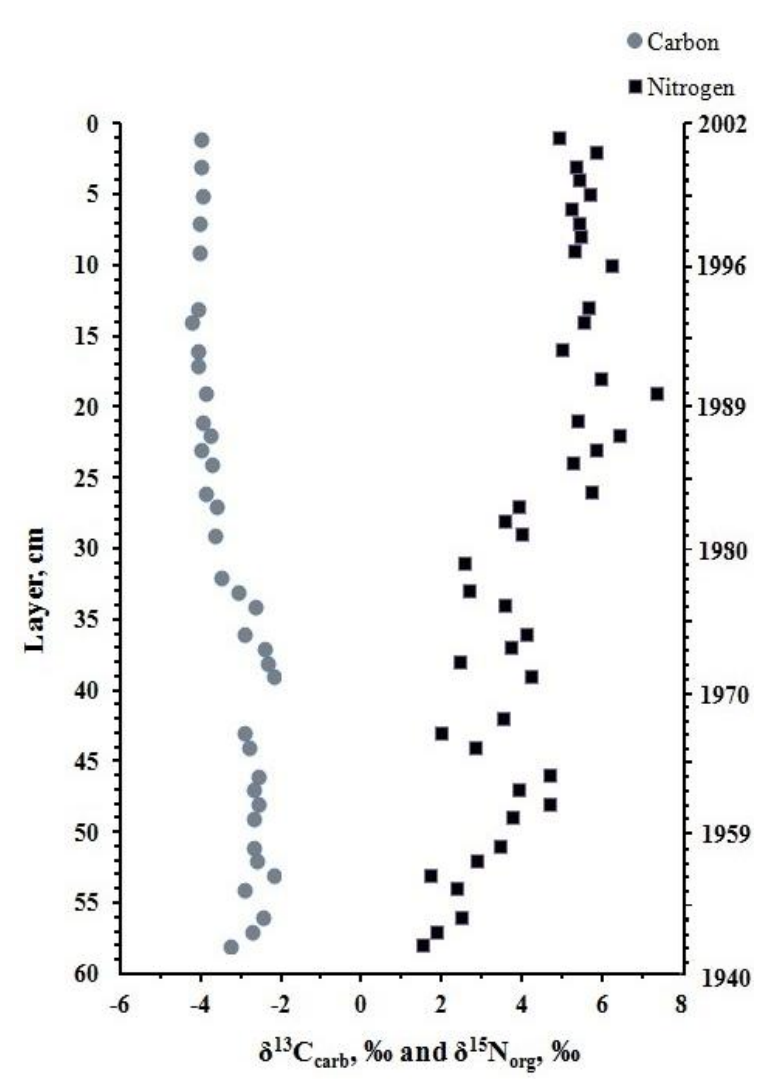
$(35-60 \mathrm{~cm})$ that has lower stable nitrogen isotope values and higher stable carbon isotope values. $\delta^{15} \mathrm{~N}$ values change from $1.5 \%$ in the lower part of the column to $7.4 \%$ in the upper part of the column. Upper interval shows more positive $\delta^{15} \mathrm{~N}$ values $(\sim 6 \%)$ while lower interval has a less positive values $(\sim 3 \%$ ). High $\delta^{15} \mathrm{~N}$ values in organics (at the depth $(0-35 \mathrm{~cm})$ can be caused by the source material from the upper trophic levels and/or biogenic effluents (Adams and Sterner 2000). Bio-productivity probably increased when brackish water inflows became more frequent into the lagoon.

Fig. 2. $\delta^{13} \mathrm{C}_{\text {carb }}$ and $\delta^{15} \mathrm{~N}_{\text {org }}$ of the bottom sediments and their dependence on the depth. Chronology of sediments determined according to ${ }^{210} \mathrm{~Pb}$ and ${ }^{137} \mathrm{Cs}$.

$\delta^{13} \mathrm{C}$ values vary from $-4.2 \%$ in the upper part of the column to $-2.2 \%$ in the lower part of the column. The upper part of the interval $(0-35 \mathrm{~cm})$ has more negative $\delta^{13} \mathrm{C}$ values $(\sim-3.5 \%)$ while lower interval $(35-60 \mathrm{~cm})$ less negative values $(\sim-2.5 \%)$. One possible reason for higher $\delta^{13} \mathrm{C}$ values $(35-60 \mathrm{~cm})$ in comparison to values of the upper layer can be explained by erosive flow from the continent (Degens et al. 1968).

\section{References}

Adams, T. S., Sterner, R. W. 2000. The effect of dietary nitrogen content on trophic level ${ }^{15} \mathrm{~N}$ enrichment. Limnology and Oceanography, 45(3), 601-607.

Degens, E. T., Guillard, R. R., Sackett, W.M., Hellebust, J.A. 1968. Metabolic fractionation of carbon isotopes in marine plankton: I. Temperature and respiration experiments. Deep-Sea Research, 15, 1-9.

Jakimavičius D., Kriaučiūnienė J. 2011. Influence of the Klaipedda Strait seaport development on the water balance of the Curonian Lagoon. In: Cygas, D., Froehner, K.D. (eds.) Environmental engineering: 8th international conference, Vilnius, Lithuania, May 19-20, 2011, Selected papers, 2. Vilnius Gediminas Technical University Press, Vilnius, pp. 573-577.

Snoeijs, P., Vilbaste, S. 1994. Intercalibration and distribution of diatom species in the Baltic sea, 2. The Baltic marine biologists publication, 16b. Opulus press, Uppsala, $125 \mathrm{pp}$. 


\section{Pleistocene glacio-isostatic seismites in NW Poland}

\section{A. J. (Tom) van Loon and Małgorzata Pisarska-Jamroży}

Adam Mickiewicz University, Poznań, Poland

NW Poland is currently not affected by tectonic activity, and thus far all soft-sediment deformation structures (SSDS) within Pleistocene deposits have been interpreted as a result of glaciotectonics, gravity-induced sliding or slumping, permafrost-induced processes, cryoturbation or fluidization or liquefaction due to instabilities resulting from reversed density gradients or from ongoing compaction resulting from ongoing accumulation of sediments. It is well known from other areas, however, that disturbances of the Earth's crust can be induced by loading/unloading cycles resulting from alternating advances and retreats of an ice-sheet (Mörner 1990). Such isostatic rebound may well induce earthquakes that leave traces in the form of SSDS in the uppermost unconsolidated sediments (Van Loon 2009; Van Loon and Maulik 2011).

NW Poland was affected by three Pleistocene glaciations: Elsterian, Saalian and Weichselian. Two "event horizons' with SSDS in a lacustrine succession (Van Loon and Pisarska-Jamroży 2014) occur at Siekierki (NW Poland) that were probably caused by earthquakes triggered by isostatic rebound after retreat of the second (Warthanian, $120 \pm 1.8$ ka) ice advance of the Saalian glaciation. The Siekierki succession consists of a $3 \mathrm{~m}$, finegrained lower part and a coarser upper part.

The lower part consists of (1) fine-grained lacustrine sediments with flasers, accumulated in a shallowing 'cold' lake, followed by (2) a wavy-laminated lithofacies deposited in a eutrophic lake during the Eemian interglacial. Piotrowski et al. (2012) dated these latter 'warm' lacustrine sediments on the base of diatom analysis as Eemian. The upper part of the Siekierki succession consists of horizontally-laminated sand and fines deposited during the Pomeranian phase.

The 'cold' lacustrine sediments contain two levels of SSDS (Fig. 1). Both these deformed layers and the undeformed material below, between and above the deformed layers consist of fine-grained sand, very fine-grained sand and admixtures of fines; no distinction in grain size can thus be made.

Most of the SSDS in the two deformed levels are loadcasts, pseudonodules, flames, and fluid-escape structures. Other SSDS, such small faults, are not related to the loadcasting process itself, but are a result of sediment disturbances. In the lower level, flame structures are bent to a more or less horizontal position, indicating an ongoing or re-activated loadcasting process after earlier generations of loadcasts had formed. It thus seems that loadcasting took place during several phases, while the sediment was still accumulating. The tendency of pseudonodules in the upper level to be concentrated in confined layer suggests that this level, too, has been affected by loadcasting during several phases.

The deformed two levels at the Siekierki site show characteristics that are consistent with 5 out of the 6 'diagnostic' criteria to recognise seismites, as proposed by Owen and Moretti (2011): (1) a large areal extent; (2) lateral continuity of deformed sediment ( 250 m); (3) vertical repetition (two levels); (4) SSDS with a morphology comparable with structures described from earthquake-affected layers; and (5) proximity to an active fault (PermoMesozoic Lower Odra Fault Zone). The only criterion that cannot be proven to be met is a change in complexity or frequency with distance from the triggering fault, because the exposure is laterally restricted. 

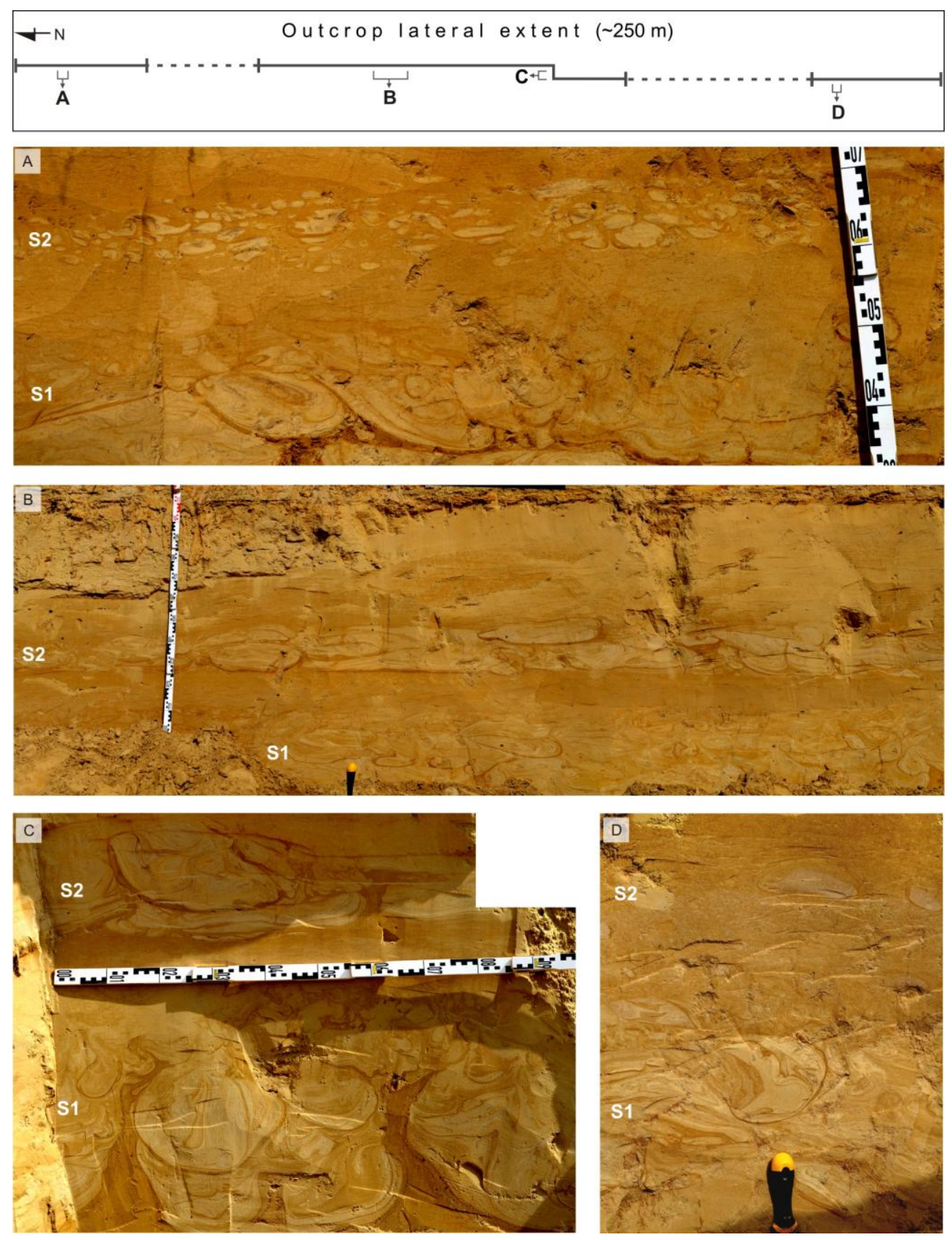

Fig. 1. The Siekierki exposure showing lateral continuity of SSDS in the lower (S1) and the upper (S2) level, with details of the deformed levels. A and B. Superposition of both deformed levels. C: Loadcasts, ball-andpillow and flame structures in the S1 and S2 levels. D: Loadcasts in the S1 level, and pseudonodules in the S2 level.

Fluctuations in the position of the ice-sheet margin of the Warthanian ice mass caused changes in the pressure exerted by the ice weight on the substratum. It is most likely that the Lower Odra Fault Zone, which is present in the vicinity of Siekierki, was re-activated during the Pleistocene as a response to the loading/unloading cycles (cf., Piotrowski 1999).

The work has been financially supported by a grant from the Polish Ministry of Science and Higher Education (research project No. N N307 057540).

\section{References}

Mörner, N.A. 1990. Glacioisostatic and long term crustal movements in Fennoscandia with respect to lithospheric and atmospheric processes and properties. Tectonophysics, 176, 13-24.

Owen, G., Moretti, M. 2011. Identifying triggers for liquefaction-induced soft-sediment deformation in sands. 
Sedimentary Geology, 235, 141-147.

Piotrowski, A. 1999. Influence of differential marginal ice-sheet loading on salt migration. Przeglad Geologiczny, 47, 1016-1021.

Piotrowski, A., Brose, F., Sydor, P., Seidler, J., Pisarska-Jamroży, M. 2012. Eemian interglacial deposits at Siekierki. In: Błaszkiewicz, M., Brose, F. (eds.), Pleistocene sediments correlations in the Lower Odra region. Państwowy Instytut Geologiczny, Warszawa, pp. 161-163.

Van Loon, A.J., 2009. Soft-sediment deformation structures in siliciclastic sediments: an overview. Geologos, $15,3-55$

Van Loon, A.J., Maulik, P. 2011. Abraded sand volcanoes as a tool for recognizing paleo-earthquakes, with examples from the Cisuralian Talchir Formation near Angul (Orissa, eastern India). Sedimentary Geology, 238, 14-155.

Van Loon, A.J., Pisarska-Jamroży, M. 2014. Sedimentological evidence of Pleistocene earthquakes in NW Poland induced by glacio-isostatic rebound. Sedimentary Geology, 300, 1-10.

\title{
MIS 2 alluvial terrace and the problem of the LGM proglacial lake in the River Vychegda valley, North-East Europe
}

\author{
Nataliya Zaretskaya ${ }^{\mathrm{a}}$, Andrei Panin $^{\mathrm{b}}$ and Valeriy Shebotinov ${ }^{\mathrm{c}}$ \\ ${ }^{\text {a }}$ Geological Institute of Russian Academy of Sciences, Russia \\ ${ }^{\mathrm{b}}$ Moscow State University, Moscow, Russia \\ ${ }^{\mathrm{c}}$ St-Petersburg State Pedagogical University, Russia
}

The LGM proglacial lake formation within river North Dvina and Vychegda valleys has been proposed so far in 1970-ties (Kvasov, 1979): thereafter, a huge lake expanded from the southeastern flank of the last glaciation upstream and exceeded the altitude of 130-135 $\mathrm{m}$ a.s.l. This would be enough to overflow into the Kama-Volga basin, and indeed a wide channel is well seen on cosmic photographs between the rivers North and South Keltma headwaters. This pass has been proposed as a spillway for the proglacial lake water discharge. This hypothesis is by now shared by a number of Russian geologists (Lavrov and Potapenko 2005) and a team from NGS (Lysa et al. 2011; Larsen et al. 2012). The evidential base is 1) sections Gam and Oz'jag with presumably lacustrine deposits and 2) reinterpretation of the extent of the Scandinavian Ice Sheet during LGM with long lobes penetrating far into Sukhona, Vaga, Vychegda and other river valleys.

Another scenario of LGM proglacial lake rise and evolution has been proposed by a group of scientists (Sidorchuk et al. 2001). Their hypothesis stated that the LGM-lake had a limited extent and did not penetrated upstream from the River Vychegda mouth. This hypothesis was based upon the studies of the Baika section of the 15-m terrace at the left bank $10 \mathrm{~km}$ upstream of the River Vychegda mouth.

Our studies of Vychegda-North Dvina fluvial system were aimed to solve the problem of proglacial lake extension and generally to reconstruct palaeoenvironment of the MiddleLate Weichselian in this area. Therefore we studied a series of sections of the alluvial terraces along the Vychegda-North Dvina fluvial system from up- to downstream. The sections are as follows: Kuryador, Storozhevsk, Niobdino, Baika along the River Vychegda, and Tolokonka section in the River North Dvina valley.

The Kuryador section (N 61 41'9", E 54 53'19", $118 \mathrm{~m}$ a.s.1.) of $13 \mathrm{~m}$ height is located at the right bank of Vychegda, and has been continuously studied by Guslitser and Duriagina (1983), Andreicheva (2011), Zaretskaya et al. (2011; 2013), Lysa et al. (2011). From the bottom to the top the section is composed of (1) $2.5 \mathrm{~m}$ thick Middle Pleistocene alluvium; (2) Middle Weichselian deposits of fluvial origin, including organic horizons ( $3 \mathrm{~m}$ in thicness), 
organic strata is of subaerial origin and represents a buried floodplain soil (Zaretskaya et al. 2013); (3) a twofold horizon of problematic origin (7.5 m thick); proglacial LGM-lake deposits (Lysa et al. 2011) or aeolian periglacial terrace (Guslitser and Duriagina 1983; Andreicheva 2011; Zaretskaya et al. 2011;2013). Radiocarbon dates of the buried soil horizon yield the continuous accumulation of the organic matter from 39.170 $\pm 260 \mathrm{BP}$ (GIN-14323) to $31.200 \pm 230$ BP (GIN-14321) (Zaretskaya et al. 2012). The dates from the bottom part of the "contradictory" horizon are as follows: $30.800 \pm 170$ BP (GIN-14569) and 26.200 $\pm 400 \mathrm{BP}$ (GIN-14320) and mark the last pre-LGM stage of organic matter accumulation. Plant composition of the samples show subaerial species, and the structure of the upper horizon demonstrates features of aeolian origin: absence of gradational bedding, micro-waving and micro-faulting formed due to summer melting of snow inclusions and indicating niveo-aeolian origin (Koster 1988; Astakhov and Svendsen 2011).

The Storozhevsk section (N61 ${ }^{\circ} 56^{\prime} 00^{\prime \prime}$, E52 $2^{\circ} 24^{\prime} 44.4^{\prime \prime}, 91 \mathrm{~m}$ a.s.1.) is located at the left bank of the middle Vychegda. This is a 6-7 $\mathrm{m}$ alluvial section underlain with the thin organic horizon (loamy peat). Radiocarbon date from this layer is 25.060 130 (GIN-1487). The terrace is of typical alluvial composition (horizontally and cross-bedded sands and gravel) and we suppose that it is of pre-LGM or early LGM age.

The Niobdino section (N 61 $55^{\prime} 15^{\prime \prime}$, E 52 $09^{\prime} 16^{\prime \prime}, 90 \mathrm{~m}$ a.s.1.) is located also within the middle Vychegda, at its right bank. This is a 6-7 m alluvial terrace underlain with silty horizon containing organic matter. Upper part (ca $5 \mathrm{~m}$ ) is composed of horizontally and cross-bedded sands, with gravel layers and with ice-wedge traces in the middle part. The underlying organic layer was radiocarbon dated as $26.300 \pm 500$ (GIN-14576). Thus we consider this terrace of pre-LGM age; in the early LGM the incision and then during the LGM a deep freezing took place, and ice-wedges have been formed.

The Baika section (N61 ${ }^{\circ} 16^{\prime} 12^{\prime \prime}, \mathrm{E} 46^{\circ} 48^{\prime} 12^{\prime \prime}, 44 \mathrm{~m}$ a.s.1.) is located within the lower Vychegda at its left bank. This is a $15 \mathrm{~m}$ terrace composed mostly of alluvial deposits, with two organic horizons at the bottom. The lower organic horizon is composed of peat and its radiocarbon age is $39.700 \pm 660$ (GIN-14868). The upper horizon is peaty soil strongly modified by ice wedges, and its radiocarbon age is $36.360 \pm 410$ (GIN-14866). The sandy part of section $(\sim 10 \mathrm{~m})$ is horizontally and cross-bedded. The spore-pollen data from this layer showed very cold climatic conditions (Sidorchuk et al. 2001), and we suppose the deposition of this layer during the LGM.

The Tolokonka section (N61 $45^{\prime} 49.55^{\prime \prime}, \mathrm{E} 45^{\circ} 28^{\prime} 34.37^{\prime \prime}, 48 \mathrm{~m}$ a.s.1.) is located in the middle course on the River North Dvina, at its right bank. This is a complex $30 \mathrm{~m}$ section, its main part is $\sim 4 \mathrm{~km}$ and has been studied and dated (Maksimov et al. 2011; Shebotinov et al. 2011; Larsen et al. 2013). In the middle part of the main section there is an organic-bearing horizon dated back at the middle Wiechselian (Maksimov et al. 2011). This horizon is overlain by $\sim 1 \mathrm{~m}$ layer earlier considered as diamicton (Shebotinov et al. 2011; Larsen et al. 2013). During our studies in 2012 we found varved clays within this "diamicton" horizon (Zaretskaya et al. 2013). The entire stratum is composed of several varved layers interbedding with alluvial sands: a deeper-water facies is gradually alternating with shallower-water from bottom to top of the stratum, and shrinkage traces are well seen at its top. Boulders and pebbles in the layer could occur from ice rafting in the proglacial lake and may therefore indicate the proximity of the glaciation margin.

There is a sandy outcrop of $28 \mathrm{~m}$ height (Upper Tolokonka) $15 \mathrm{~km}$ upstream from the main section. This section is mostly composed of sandy layers; only at the bottom part there is a thin silty layer containing organic matter. The radiocarbon date is $24.570 \pm 140$ (GIN-14874). In the middle part, there is $1-\mathrm{m}$ varved layer. Varves are composed of silty sand, and can 
indicate a distal (shallow) part of the proglacial lake. Probably the Tolokonka terrace is a combination of two terraces of different ages with the younger terrace dated around $25 \mathrm{ka} \mathrm{BP}$ resting to the older terrace of the Eemian age.

Analysed sections and dated samples allowed us to maintain that the LGM proglacial lake did not exceed the Vychegda river mouth. The alluvial terrace was forming during the LGM within the Vychegda valley, which now is a component of the 1st river terrace. Accumulation of this terrace had probably been promoted by the backwater effect from the proglacial lake. The LGM proglacial lake was spreading upstream from the SE margin of the last glaciation (boundaries according to Demidov et al. 2006, Larsen et al. 2006) not more than 200-250 km.

Probably the low terrace of Vychegda, like the Tolokonka terrace, is a composite body composed of two parts: pre-LGM and post-LGM. This is evident from radiocarbon dates from alluvium of the 6-7-m terrace (Zaretskaya et al. 2014) that separate into two corresponding groups.

\section{Key references}

Astakhov, V.I., Svendsen, J.I. 2011. The cover sediments of the final Pleistocene in the extreme northeast of European Russia. Regionalnaya Geologia i Metallogenia, 47, 12-27 (in Russian).

Maksimov, F.E., Kuznetsov, V.Yu., Zaretskaya, N.E., Subetto, D.A., Shebotinov, V.V., Zherebtsov, I.E., Levchenko, S.B., Kuznetsov, D.D., Larsen, E., Lysö, A., Jensen, M. 2011. The first case study of ${ }^{230} \mathrm{Th} / \mathrm{U}$ and ${ }^{14} \mathrm{C}$ dating of Mid-Valdai organic deposits. Doclady Earth Sciences, 438(1), 598-603.

Demidov, I.N., Houmark-Nielsen, M., Kjaer, K.H., Larsen, E. 2006. The last Scandinavian Ice Sheet in northwestern Russia: ice flow patterns and decay dynamics. Boreas, 35, 425-443. (?)

Koster, E.A., 1988. Ancient and modern cold climate aeolian sand deposition: a review. Journal of Quaternary Science, 3, 69-83.

Larsen, E., Kjær, K.H., Demidov, I.N., Funder, S., Grøsfjeld, K., Houmark-Nielsen, M., Jensen, M., Linge, H., Lysa, A., 2006. Late Pleistocene glacial and lake history of northwestern Russia. Boreas, 35(3), 394-424.

Lavrov, A.S., Potapenko, L.M. 2005. Neopleistocene of the North-East of the Russian Plain. Aerogeology, Moscow, 191 pp. (In Russian)

Lyså, A., Jensen, M., Larsen, E., Fredin, O., Demidov, I., 2011. Ice-distal landscape and sediment signatures evidencing damming and drainage of large pro-glacial lakes, northwest Russia. Boreas, 40(3), p. 481-497.

Sidorchuk, A., Panin, A., Borisova, O., Kovalyukh, N. 2001. Lateglacial and Holocene palaeohydrology of the lower Vychegda river, western Russia. In: Maddy, D., Macklin, M.G., \& Woodward, J.C. (eds.), River basin sediment Systems: Archives of Environmental Change. A.A.Balkema Publishers, pp. 265-295.

Zaretskaya, N.E., Pansin, A.V., Golubeva, Yu.V., Chernov, A. V. 2014. Sedimentation settings and the Late Pleistocene-Holocene: geochronology in the Vychegda River Valley. Doclady Earth Sciences, 455(1), 223-228.

Zaretskaya, N.E., Shebotinov, V.V., Panin, A.V., Maksimov, F.E., Kuznetsov, V.Yu., Symakova, A.N. 2013. Geochronology and problems of the Late Pleistocene palaeogeography in the Vychegda- North Dvina fluvial system. Proceedings of the VIII Quaternary Symposium, Rostov-na-Donu. Southern Science Center of Russian Academy of Sciences, pp. 204-206. (In Russian)

\section{A giant loadcast resulting from ice re-advance over an esker near Ryssjön, South Sweden}

\section{A. J. (Tom) van Loon and Beata Gruszka}

Adam Mickiewicz University, Poznań, Poland

Large areas of southern Sweden are covered by Pleistocene glacigenic sediments that cover a Precambrian basement. The glaciations left a large number of eskers, which are at many places exploited in relatively small quarries for their gravel and sand content. One of these quarries is situated near Ryssjön, some $4 \mathrm{~km} \mathrm{SW}$ of Nykvarn (Fig. 1). The walls of the 
quarry are up to about $10 \mathrm{~m}$ high, and Precambrian bedrock with a well-polished surface crops out locally.

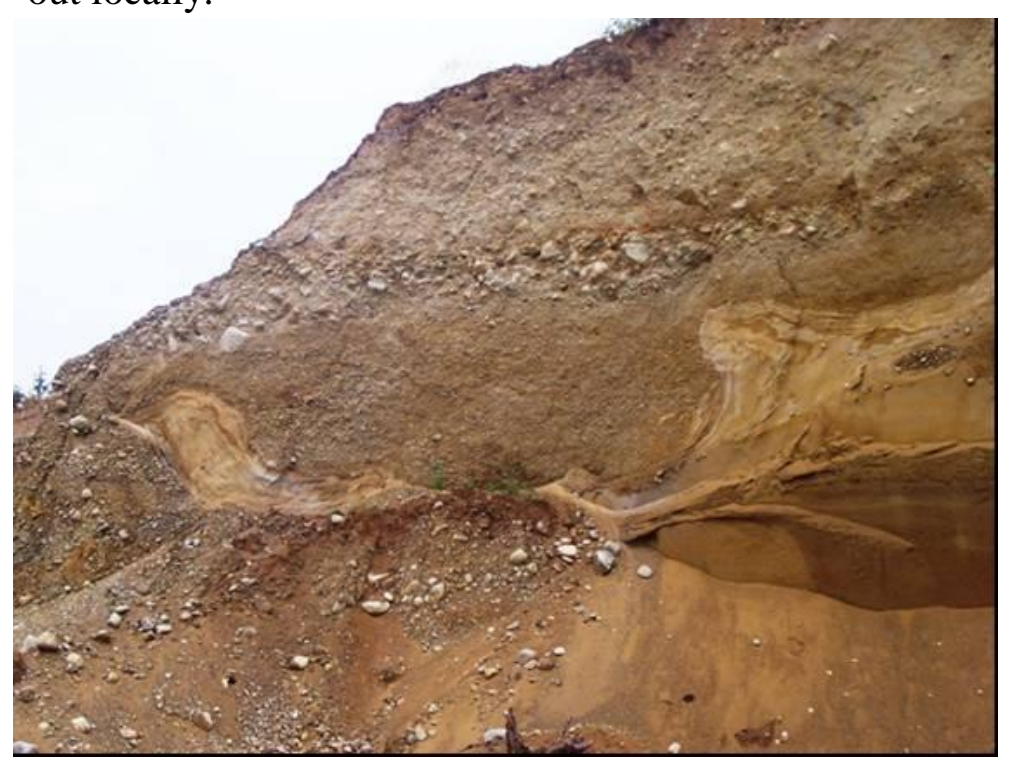

Fig. 1. The giant loadcast near Ryssjön. Its width is approximately $8 \mathrm{~m}$.

The loadcast has deformed the underlying medium-sized sand, which contains only a relatively small amount of pebbles, often in the form of pebble strings. These sands have a thickness of $0.5-1 \mathrm{~m}$ in the direct vicinity of the loadcast, but reach a thickness of some $3 \mathrm{~m}$ more to the SW, where they form themselves a large loadcast that seems to have sagged down in more or less similar sands.

There can be no doubt as to the loadcast character of the structures, because (1) it formed a downward thickened part of a layer that extended laterally as a more or less straight, horizontal gravel bed, (2) the structure had a distinct synform appearance, and (3) the underlying deposits were clearly folded parallel to the basis of the structure. Moreover, gravel particles are much heavier than water-saturated sands, so a reversed density gradient must have existed.

Two questions arise from the exceptional structure: (1) what caused the gravel to load into medium-grained material, and (2) why did the loadcast reach such an extreme dimension? In this context the overlying sediments seem to form the key. The gravel layer that forms the parent rock of the giant loadcast is overlain by a unit of maximally $80 \mathrm{~cm}$ thick consisting of densely packed gravel with boulders up to some $50 \mathrm{~cm}$. Then follows some kind of transitional zone of about $5 \mathrm{~cm}$ thick; it is coloured red, brown and yellow, which indicates that rising groundwater could not penetrate the overlying unit. The unit on top of this boundary zone is a diamicton of maximally $2 \mathrm{~m}$ thick; pebbles of up to about $20 \mathrm{~cm}$ float in a matrix of very compact clayey sand.

We interpret this succession as representing the area just in or in front of a subglacial tunnel. The strong subglacial streams built a body of sand and gravels that would form, after retreat of the glacier, form an esker. The esker ridge was then overridden by ice again during a phase of re-advance. This resulted in the deposition of the till layer on top of the esker sediments in a strict sense.

The new ice cover was thick enough to exert considerable pressure on the sediments underneath, as shown by the strong compaction of the till layer, which consequently must represent a till formed at the base of the ice. It was not a lodgement till, however, as the joint systems that characterise true lodgement tills are absent; it may well be that the re-advancing glacier was not thick enough to produce a true lodgement till. The ice body must certainly have been large enough, however, to exert a vertical pressure on the underlying sediments to trigger the loading of the gravel layer into the underlying water-saturated sands. Once the gravel started to load, ever more pore-water was pressed out of the sand, thus providing more space for growth of the loadcast. This process may have come to an end when the - probably short-lived - ice re-advance changed into a renewed retreat of the ice. 


\section{LIST OF PARTICIPANTS}

\section{ASTAKHOV Valery}

St. Petersburg State University

Universitetskay Str. 7/9,

199034, St. Petersburg, Russia

E-mail: val@nb15514.spb.edu

BIKŠE Jānis

Faculty of Geography and Earth Sciences, University of Latvia

Rainis Blvd. 19

LV-1010, Rīga, Latvia

E-mail: janis.bikse@lu.lv

BÖSE Margot

Physical Geography, Freie Universität Berlin

Malteserstraße 74-100

12249, Berlin, Germany

E-mail: m.boese@fu-berlin.de

CELIN̦Š Ivars

Faculty of Geography and Earth Sciences, University of Latvia

Rainis Blvd. 19

LV-1010, Rīga, Latvia

E-mail: ivars.celins@inbox.lv

DĒLIN̦A Aija

Faculty of Geography and Earth Sciences, University of Latvia

Rainis Blvd. 19

LV-1010, Rīga, Latvia

E-mail: aija.delina@lu.lv

GEDMINIENĖ Laura

Department of Geology and Mineralogy, Vilnius

University

M.K.Čiurlionio g. 21/27

LT-03101, Vilnius, Lithuania

E-mail: lauragedminiene@yahoo.com

\section{GRUBE Alf}

Geological Survey Schleswig-Holstein (State Agency for Agriculture, Environment and Rural Areas of the Federal State Schleswig-Holstein)

Hamburger Chaussee 25

24220, Flintbek, Germany

E-mail: Alf.Grube@1lur.landsh.de

\section{JOHANSSON Peter}

Geological Survey of Finland

P.O. Box 77

FIN-96101, Rovaniemi, Finland

E-mail:peter.johansson@gtk.fi
BĒRZIN̦Š Dāvids

Faculty of Geography and Earth Sciences, University

of Latvia

Rainis Blvd. 19

LV-1010, Rīga, Latvia

E-mail: berzinsdavid@gmail.com

BÖRNER Andreas

State authority for Environment, Nature protection and Geology of Mecklenburg-Vorpommern, State

Geological Survey

Goldberger Str. 12

18273, Güstrow, Germany

E-mail: andreas.boerner@lung.mv-regierung.de

\section{BREGMAN Enno}

Province of Drenthe/Utrecht University

Aquarius 58

9405 RC Assen, The Netherlands

E-mail: enno.bregman@gmail.com

\section{CERIN,A Aija}

Faculty of Geography and Earth Sciences, University of Latvia

Rainis Blvd. 19

LV-1010, Rīga, Latvia

E-mail: aija.cerina@lu.lv

DRUZHININA Olga

I. Kant Baltic Federal University

A. Nevsky Prospekt 14 B

236038, Kaliningrad, Russia

E-mail:olga.alex.druzhinina@gmail.com

\section{GRIGIENE் Alma}

Lithuanian Geological Survey

S. Konarskio Str., 35

LT-03123, Vilnius, Lithuania

E-mail: alma.grigiene@1gt.lt

\section{HARDT Jacob}

Physical Geography, Freie Universität Berlin

Malteserstraße 74-100

12249, Berlin, Germany

E-mail: Jacob.hardt@fu-berlin.de

JUSIENE் Asta

Lithuanian Geological Survey

S. Konarskio Str., 35

LT-03123, Vilnius, Lithuania

E-mail: asta.jusiene@1gt.lt 


\section{KALIŃSKA-NARTIŠA Edyta \\ University of Tartu \\ Ülikooli 18 \\ 50090, Tartu, Estonia \\ E-mail: edyta.kalinska@ut.ee}

\section{KALNINA Laimdota}

Faculty of Geography and Earth Sciences, University of Latvia

Rainis Blvd. 19

LV-1010, Rīga, Latvia

E-mail: laimdota.kalnina@lu.lv

KARMAZIENÉ Danguolè

Lithuanian Geological Survey

S. Konarskio Str. 35

LT-03123, Vilnius, Lithuania

E-mail: danguole.karmaziene@lgt.lt

\section{KRIEVĀNS Māris}

Faculty of Geography and Earth Sciences, University of Latvia

Rainis Blvd. 19

LV-1586, Rīga, Latvia

E-mail: maris.krievans@lu.lv

\section{KUZNETSOV Denis}

Institute of Limnology, Russian Academy of Sciences Sevastyanova Str., 9

196105, St.-Petersburg, Russia

E-mail: dd_kuznetsov@mail.ru

\section{LOMP Pille}

Institute of Ecology and Earth Sciences, University of Tartu

Ravila 14a

EE-50411, Tartu, Estonia

E-mail: pille.lomp@ut.ee

\section{MAKSIMOV Anton}

A.P.Karpinsky Russian Geological Research Institute (VSEGEI)

Sredny prospect 74

199106, St.-Petersburg, Russia

E-mail: Anton_Maksimov@vsegei.ru

\section{NARTIŠS Māris}

Faculty of Geography and Earth Sciences, University of Latvia

Rainis Blvd. 19

LV-1586, Rīga, Latvia

E-mail: maris.nartiss@gmail.com

\section{KALLA Katrin}

Department of Geology, Institute of Ecology and Earth Sciences, University of Tartu

Ravila 14a

50411, Tartu, Estonia

E-mail:katrin.kalla@ut.ee

KARMAZA Bronislavas

Institute of Geology and Geography, Nature Research Centre

Akademijos Str. 2

LT-08412, Vilnius, Lithuania

E-mail: karmaza@geo.lt

KARUŠS Jānis

Faculty of Geography and Earth Sciences, University of Latvia

Rainis Blvd. 19

LV-1586, Rīga, Latvia

E-mail: janis.karuss@inbox.lv

KUKSA Kathrine

St.Petersburg State University

$10^{\text {th }}$ Line V.O., 33/35

199178, St. Petersburg, Russia

E-mail:kkuksa@gmail.com

\section{LAMSTERS Kristaps}

Faculty of Geography and Earth Sciences, University of Latvia

Rainis Blvd. 19

LV-1586, Rīga, Latvia

E-mail: kristaps.lamsters@gmail.com

\section{LUDIKOVA Anna}

Institute of Limnology, Russian Academy of Sciences Sevastyanova Str., 9

196105, St. Petersburg, Russia

E-mail: ellerbeckia@yandex.ru

\section{MARKOTS Aivars}

Faculty of Geography and Earth Sciences, University of Latvia

Rainis Blvd. 19

LV-1586, Rīga, Latvia

E-mail: aivars.markots@lu.lv

PANIN Andrei

Faculty of Geography, Lomonosov Moscow State

University

Vorobyevy Gory 1

119991, Moscow, Russia

E-mail: a.v.panin@yandex.ru 
PISARSKA-JAMROŻY Małgorzata

Institute of Geology, Adam Mickiewicz University

ul. Maków Polnych 15

61-606, Poznań, Poland

E-mail: pisanka@amu.edu.pl

PUKELYTE் Violeta

Institute of Geology and Geography, Nature Research Centre

T. Ševčenkos Str. 13

LT-03223, Vilnius, Lithuania

E-mail: pukelyte@geo.lt

RETIĶE Inga

Faculty of Geography and Earth Sciences, University of Latvia

Rainis Blvd. 19

LV-1586, Rīga, Latvia

E-mail: inga.retike@lu.lv

RUDNICKAITÉ Eugenija

Department of Geology and Mineralogy, Vilnius

University

M.K.Čiurlionio 21/27

LT-03103, Vilnius, Lithuania

E-mail: eugenija.rudnickaite@gf.vu.lt

SARALA Pertti

Geological Survey of Finland

P.O. Box 77

96101, Rovaniemi, Finland

E-mail: pertti.sarala@gtk.fi

SHEBOTINOV Valery

St-Petersburg State Pedagogical University

Moika 48

191186, St.Petersburg, Russia

E-mail:scif@berendei.info

STAŠKOVA Anda

Faculty of Geography and Earth Sciences, University of Latvia

Rainis Blvd. 19

LV-1586, Rīga, Latvia

E-mail: anda.staškova@inbox.lv

STRAUTNIEKS Ivars

Faculty of Geography and Earth Sciences, University of Latvia

Rainis Blvd. 19

LV-1586, Rīga, Latvia

E-mail: ivars.strautnieks@lu.lv

VAIKUTIENE Giedre

Vilnius University

Ciurlionio 21/27

LT-03101, Vilnius, Lithuania

E-mail: giedre.vaikutiene@gf.vu.lt
PUJĀTE Agnese

Faculty of Geography and Earth Sciences, University of Latvia

Rainis Blvd. 19

LV-1586, Rīga, Latvia

E-mail: agnese.pujate@gmail.com

REČS Agnis

Faculty of Geography and Earth Sciences, University of Latvia

Rainis Blvd. 19

LV-1586, Rīga, Latvia

E-mail: agnis.recs@lu.lv

ROELFS Gretha

Geopark de Hondsrug

Bronnegerstraat 12

9531 TG Borger,The Netherlands

E-mail: G.roelfs@drenthe.nl

\section{SAARSE Leili}

Institute of Geology at Tallinn University of

Technology

Ehitajate tee 5

19086, Tallinn, Estonia

E-mail: leili.saarse@ttu.ee

SEMENOVA Lyudmila

A.P.Karpinsky Russian Geological Research Institute (VSEGEI)

Sredny prospect 74

199106, St.-Petersburg, Russia

E-mail: ljudmilasemenova@mail.ru

SOMS Juris

Department of Chemistry and Geography, Daugavpils University

Vienības Str. 13

LV-5401, Daugavpils, Latvia

E-mail: juris.soms@du.lv

STIVRIN̦Š Normunds

Tallinn University of Technology

Ehitajate tee 5

19086 Tallinn, Estonia

E-mail: normunds.stivrins@ttu.ee

TABUNS Eriks

St.Petersburg State University

$10^{\text {th }}$ Line V.O., 33/35

199178, St. Petersburg, Russia

E-mail: eriks.tabuns@ailgroup.org

Van LOON A. J. (Tom)

Institute of Geology, Adam Mickiewicz University

ul. Maków Polnych 15

61-606, Poznań, Poland

E-mail: tvanloon@amu.edu.pl 


\section{ZARETSKAYA Nataliya}

Geological Institute of Russian Academy of Sciences Pyzhevsky pereulok, 7

119017, Moscow, Russia

E-mail: N_zaretskaya@inbox.ru

\section{ZELČS Vitālijs}

Faculty of Geography and Earth Sciences, University of Latvia

Rainis Blvd. 19

LV-1586, Rīga, Latvia

E-mail: vitalijs.zelcs@lu.lv 


\section{NOTES}




\section{NOTES}




\section{LATVIJAS}

UNIVERSITATE

ANNO 1919

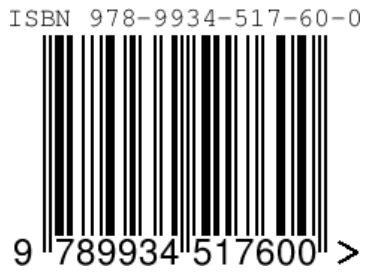

